Supporting Information for

\title{
A Practical, Component-Based Synthetic Route to Methylthiolincosamine Permitting Facile Northern-Half Diversification of Lincosamide Antibiotics
}

\author{
Matthew J. Mitcheltree, Jack W. Stevenson, Amarnath Pisipati, and Andrew G. Myers* \\ * To whom correspondence should be addressed: myers@ chemistry.harvard.edu (A.G.M.) \\ Department of Chemsitry and Chemical Biology \\ Harvard University, Cambridge, MA, USA
}




\section{Table of Contents}

General Experimental Procedures.

Materials

$\begin{array}{lc}\text { Instrumentation } & 5\end{array}$

$\begin{array}{lr}\text { Antimicrobial Assays } & 6\end{array}$

$\begin{array}{ll}\text { Synthesis of Building Blocks } 9 \text { and } 10 & 7\end{array}$

$\begin{array}{ll}\text { Synthesis of Isoxazoline } N \text {-oxides } 17 \text { and } 18 & 19\end{array}$

$\begin{array}{ll}\text { Synthesis of Methylthiolincosamine (1) } & 23\end{array}$

Synthesis of $C$-Glycosides 29, 30, and 31

Synthesis of the Fully Synthetic Lincosamide 37 66

$\begin{array}{ll}\text { Synthesis of 8-Norlincomycin (42) } & 74\end{array}$

Synthesis of Fully Synthetic Lincosamide Analogs 43-50 95

$\begin{array}{ll}\text { Catalog of X-ray Crystal Structures } & 134\end{array}$

Crystallographic Data for Compound 17

Crystallographic Data for Compound 22b 143

$\begin{array}{ll}\text { Crystallographic Data for Compound } 31 & 150\end{array}$

$\begin{array}{ll}\text { Catalog of NMR Spectra } & 156\end{array}$ 


\section{General Experimental Procedures.}

All reactions were performed in oven- or flame-dried round-bottomed or modified Schlenk flasks fitted with rubber septa under a positive pressure of argon (dried by passage through a column of Drierite calcium sulfate desiccant), unless otherwise noted. Air- and moisture-sensitive liquids and solutions were transferred via syringe or stainless-steel cannula. When necessary (so noted), solutions were deoxygenated by three cycles of freezing (liquid nitrogen), evacuation, and thawing under static vacuum. Organic solutions were concentrated by rotary evaporation (house vacuum, $\sim 60$ Torr) at $23-30{ }^{\circ} \mathrm{C}$. Flash-column chromatography was performed as described by Still et al., ${ }^{1}$ employing silica gel (60-Å pore size, 230-400 mesh, Agela Technologies, Chicago, IL; or RediSep silica cartridges, Teledyne Isco, Lincoln, NE). Analytical thin-layer chromatography (TLC) was performed using glass plates pre-coated with silica gel $(0.25 \mathrm{~mm}, 60$ Å pore size, $230-400$ mesh, Merck KGA) impregnated with a fluorescent indicator (254 nm). In special cases (so noted), analytical TLC was performed with aminopropyl-modified silica gel $\left(\mathrm{NH}_{2}\right.$ silica gel, $60-\AA$ pore size, Wako Chemicals USA) impregnated with a fluorescent indicator (254 $\mathrm{nm}$ ). TLC plates were visualized by exposure to ultraviolet light (UV) and/or exposure to iodine vapor $\left(\mathrm{I}_{2}\right)$, basic aqueous potassium permanganate solution $\left(\mathrm{KMnO}_{4}\right)$, acidic ethanolic paraanisaldehyde solution (PAA), acidic aqueous ceric ammonium molybdate solution (CAM), or ethanolic solution of phosphomolybdic acid (PMA) followed by brief heating on a hot plate as needed $\left(\sim 200{ }^{\circ} \mathrm{C}, \leq 15 \mathrm{~s}\right) .^{2}$ In some cases, reaction monitoring was carried out by analytical liquid chromatography-mass spectrometry (LCMS), or by flow-injection analysis-high-resolution mass spectrometry (FIA-HRMS).

\footnotetext{
${ }^{1}$ Still, W. C.; Khan, M.; Mitra, A. J. Org. Chem. 1978, 43, 2923-2925.

${ }^{2}$ Sanford, M. TLC stains. Umich.edu/ mssgroup/docs/TLCStains.pdf (accessed April 14, 2018).
} 


\section{Materials}

Commercial reagents and solvents were used as received, unless mentioned otherwise. Dichloromethane, ethyl ether, tetrahydrofuran, 1,4-dioxane, $N, N$-dimethylformamide, toluene, and benzene were purified by passage through $\mathrm{Al}_{2} \mathrm{O}_{3}$ under argon, according to the method of Pangborn et al. ${ }^{3}$ 5'-(4-Fluorobutyl)azepine acid 35 and 1-(chloromethylene)pipiridine-1-ium chloride (Vilsmeier reagent $\mathbf{3 3}$ ) were prepared according to Lewis and co-workers. ${ }^{4}$ Trans-4-npropyl-L-hygric acid hydrochloride (41) was prepared from lincomycin according to Herr and Slomp. ${ }^{5}$ Ethynyltriisopropylsilane, triethylphosphonoacetate, 1,8-diazabicyclo[4.5.0]undec-7-ene, (-)-diethyl-D-tartrate, tert-butylchlorodiphenylsilane, chlorotriisopropylsilane, imidazole, trimethyl phosphite, sodium triacetoxyborohydride, trifluoroacetic acid, 1-[2(trimethylsilyl)ethoxycarbonyloxy]pyrrolidin-2,5-dione (Teoc-OSu), Oxone monopersulfate compound, hexamethyldisilazane, methyl trifluoroacetate, HATU, and 2,4,6trimethylbenzenesulfonyl chloride were purchased from Oakwood Products, Inc. (Estill, SC, USA). Anhydrous cupric acetate and tungsten hexacarbonyl (99\%, <0.3\% molybdenum) were purchased from Strem Chemicals, Inc. (Newburyport, MA, USA). 4-(tertButylthio)phenylboronic acid was purchased from Alchem Pharmtech, Inc. (Monmouth Junction, NJ, USA). (4-Mercaptophenyl)(morpholino)methanone (S29) was prepared according to published procedures. ${ }^{6}$ 4-Pyridin-3-ylaniline (S37) was purchased from Maybridge Chemical

\footnotetext{
${ }^{3}$ Pangborn, A. B.; Giardello, M. A.; Grubbs, R. H.; Rosen, R. K.; Timmers, F. J. Organometallics 1996, 15, 15181520.

${ }^{4}$ Lewis, J. G.; Anandan, S. K.; O’Dowd, H.; Gordeev, M. F.; Li, L. Lincomycin derivatives possessing antibacterial activity. US Patent 7,361,743 B2, April 22, 2008.

${ }^{5}$ Herr, R. R.; Slomp, G. J. Am. Chem. Soc. 1967, 89, 2444-2447.

${ }^{6}$ Ahlmark, M.; Din, B. D.; Kauppala, M.; Luiro, A.; Pajunen, T.; Pystynen, J.; Tiainen, E.; Vaismaa, M.; Messinger, J. Preparation of 2-substituted 4,5-dihydroxyisophthalonitriles and their analogs as inhibitors of catechol-Omethyltransferase for the treatment of Parkinson's disease. WO Patent 2013175053A1, May 23, 2013.
} 
Company (Altrincham, UK). All other chemicals and reagents were purchased from SigmaAldrich Corporation (Natick, MA, USA).

\section{Instrumentation}

Proton nuclear magnetic resonance $\left({ }^{1} \mathrm{H}\right.$ NMR) spectra and carbon nuclear magnetic resonance $\left({ }^{13} \mathrm{C}\right.$ NMR) spectra were recorded on Varian Mercury $400(400 \mathrm{MHz} / 100 \mathrm{MHz})$, Varian Inova 500 (500 MHz/125 MHz), or Varian Inova 600 (600 MHz/150 MHz) NMR spectrometers at $23^{\circ} \mathrm{C}$. Proton chemical shifts are expressed in parts per million (ppm, $\delta$ scale) and are referenced to residual protium in the NMR solvent $\left(\mathrm{CHCl}_{3}, \delta 7.26 ; \mathrm{CHD}_{2} \mathrm{OD}, \delta 3.31 ; \mathrm{C}_{6} \mathrm{D}_{5} \mathrm{H}, \delta\right.$ 7.16). Carbon chemical shifts are expressed as parts per million (ppm, $\delta$ scale) and are referenced to the carbon resonance of the NMR solvent $\left(\mathrm{CDCl}_{3}, \delta 77.2 ; \mathrm{CD}_{3} \mathrm{OD}, \delta 49.0 ; \mathrm{C}_{6} \mathrm{D}_{6}, \delta\right.$ 128.1). Data are reported as follows: Chemical shift, multiplicity $(\mathrm{s}=$ singlet, $\mathrm{d}=$ doublet, $\mathrm{t}=$ triplet, $\mathrm{q}=$ quartet, $\mathrm{qn}=$ quintet, $\mathrm{dd}=$ doublet of doublets, $\mathrm{td}=$ triplet of doublets, $\mathrm{ABq}=\mathrm{AB}$ quartet, $\mathrm{m}=$ multiplet, $\mathrm{br}=$ broad, app $=$ apparent $)$, integration, and coupling constant $(J)$ in Hertz $(\mathrm{Hz})$. Infrared transmittance (IR) spectra were obtained using a Bruker ALPHA FTIR spectrophotometer referenced to a polystyrene standard. Data are represented as follows: Frequency of absorption $\left(\mathrm{cm}^{-1}\right)$, and intensity $(\mathrm{s}=$ strong, $\mathrm{m}=$ medium, $\mathrm{br}=$ broad). Melting points were determined using a Thomas Scientific capillary melting point apparatus. High-resolution mass spectrometry (including FIA-HRMS reaction monitoring) was performed at the Harvard University Mass Spectrometry Facility using a Bruker micrOTOF-QII mass spectrometer. X-ray crystallographic analysis was performed at the Harvard University X-Ray Crystallographic Laboratory by Dr. Shao-Liang Zheng. Highperformance liquid chromatography-mass spectrometry (LCMS) was performed using an Agilent Technologies 1260-series analytical HPLC system in tandem with an Agilent Technologies 6120 
Quadrupole mass spectrometer; a Zorbax Eclipse Plus reverse-phase $\mathrm{C}_{18}$ column $(2.1 \times 50 \mathrm{~mm}$, $1.8 \mu \mathrm{m}$ pore size, 600 bar rating; Agilent Technologies, Santa Clara, CA) was employed as stationary phase. LCMS samples were eluted at a flow rate of $650 \mu \mathrm{L} / \mathrm{min}$, beginning with $5 \%$ acetonitrile-water containing $0.1 \%$ formic acid, grading linearly to $100 \%$ acetonitrile containing $0.1 \%$ formic acid over 3 minutes, followed by $100 \%$ acetonitrile containing $0.1 \%$ formic acid for 2 minutes (5 minutes total run time).

\section{Antimicrobial Assays}

The minimum inhibitory concentrations (MICs) for both test and control compounds were performed in accordance with guidelines of the Clinical Laboratory Standards Institute (CLSI) ${ }^{7}$ for broth microdilution susceptibility testing. Bacterial strains MMX 3028 (S. pneumoniae, cErmB genotype), MMX 3031 (S. pneumoniae, cMefA genotype), and MMX 946 (S. pyogenes, MLSB phenotype) were purchased from Micromyx, LLC (Kalamazoo, MI, USA). Bacterial strains ATCC 29213 (S. aureus), BAA 977 (S. aureus, iErmA genotype), ATCC 49619 (S. pneumoniae), ATCC 19615 (S. pyogenes), ATCC 29212 (E.faecalis), ATCC 10031 (K. pneumoniae), ATCC 25922 (E. coli), ATCC 27853 (P. aeruginosa), and ATCC 49247 (H. influenzae) were purchased from the American Type Culture Collection (Manassas, VA, USA).

Compound Numbering. For clarity, intermediates that have not been assigned numbers in the preceding text are numbered sequentially in this section, beginning with $\mathbf{S 1}$.

\footnotetext{
${ }^{7}$ Clinical and Laboratory Standards Institute. Methods for Dilution Antimicrobial Susceptibility Tests for Bacteria that Grow Aerobically_-Tenth Edition: Approved Standard M07-A10. CLSI, Wayne, PA, U.S.A., 2015.
} 


\section{Synthesis of Building Blocks 9 and 10}

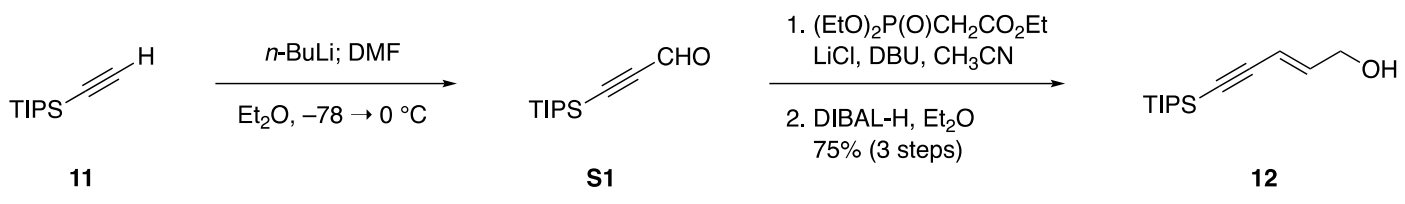

\section{Enynol 12.}

Formylation of ethynyltriisopropylsilane was performed according to the procedure reported by Robles and McDonald. ${ }^{8}$ To a solution of ethynyltriisopropylsilane (11, $20.0 \mathrm{~g}, 110$ mmol, 1 equiv) in ethyl ether $(100 \mathrm{~mL})$ was added $n$-butyllithium solution $(2.12 \mathrm{M}$ in hexane, 51.7 $\mathrm{mL}, 110 \mathrm{mmol}, 1.00$ equiv) slowly by cannula at $0{ }^{\circ} \mathrm{C}$ over approximately $15 \mathrm{~min}$. The resulting solution was stirred at $0{ }^{\circ} \mathrm{C}$ for an additional $40 \mathrm{~min}$. This lithium acetylide solution was then transferred via cannula over a period of 5-10 min to a 500-mL round-bottomed flask containing a mixture of $N, N$-dimethylformamide $(25.5 \mathrm{~mL}, 329 \mathrm{mmol}, 3.00$ equiv) and ethyl ether (100 $\mathrm{mL})$ chilled to $-78{ }^{\circ} \mathrm{C}$. A white suspension formed. The reaction mixture was stirred at $-78{ }^{\circ} \mathrm{C}$ for $1 \mathrm{~h}$ before warming to $0{ }^{\circ} \mathrm{C}$, at which temperature the mixture became homogeneous. After $1 \mathrm{~h}$ of stirring at $0{ }^{\circ} \mathrm{C}$, the mixture was transferred to an ice-cold aqueous sulfuric acid solution (5\% v/v, $250 \mathrm{~mL}$ ). The resulting biphasic mixture was stirred at $0{ }^{\circ} \mathrm{C}$ for $1 \mathrm{~h}$, and then the layers were separated. The aqueous phase was extracted with ethyl ether $(3 \times 150 \mathrm{~mL})$, and the combined organic extracts were washed with saturated aqueous sodium chloride solution $(150 \mathrm{~mL})$. The washed organic solution was dried over sodium sulfate, the dried solution was filtered, and the filtrate was concentrated to give 3-(triisopropylsilyl)propiolaldehyde (S1) as a colorless oil that was used in the next step without further purification. The ${ }^{1} \mathrm{H}$ NMR data matched literature values. ${ }^{8}$

\footnotetext{
${ }^{8}$ Robles, O.; McDonald, F. E. Org. Lett. 2008, 10, 1811-1814.
} 
Horner-Wadsworth-Emmons olefination of the crude ynal formed in the preceding formylation reaction was performed according to the procedure reported by Bode and co-workers. ${ }^{9}$ An oven-dried 2-L round-bottomed flask was charged with lithium chloride (5.60 g, $132 \mathrm{mmol}$, 1.20 equiv), and the apparatus was flame-dried. Once cooled, the flask was charged with a magnetic stir bar and acetonitrile $(1.3 \mathrm{~L})$, and the resulting suspension was stirred at $23{ }^{\circ} \mathrm{C}$ for 10 min (lithium chloride does not fully dissolve). 3-(Triisopropylsilyl)propriolaldehyde (S1, theoretically $110 \mathrm{mmol}, 1$ equiv) and triethyl phosphonoacetate $(22.5 \mathrm{~mL}, 112 \mathrm{mmol}, 1.02$ equiv) were then added sequentially. 1,8-Diazabicyclo[5.4.0]undec-7-ene (DBU, $16.6 \mathrm{~mL}, 110 \mathrm{mmol}$, 1.00 equiv) was added dropwise over $5 \mathrm{~min}$, causing the mixture to warm to approximately $40{ }^{\circ} \mathrm{C}$ with concomitant transformation of the originally colorless reaction solution to an opaque, offwhite suspension. Progress was monitored by TLC (20\% dichloromethane-hexanes, UV+PAA); after $10 \mathrm{~min}$, the reaction was judged to be complete. The mixture was concentrated by rotary evaporation to a volume of approximately $300 \mathrm{~mL}$, and the concentrated mixture was transferred to a separatory funnel containing saturated aqueous ammonium chloride solution $(400 \mathrm{~mL})$ and ethyl ether $(300 \mathrm{~mL})$. The mixture was shaken, and the layers were separated. The aqueous phase was extracted with ethyl ether $(3 \times 300 \mathrm{~mL})$; the combined organic layers were then washed sequentially with water $(250 \mathrm{~mL})$ and saturated aqueous sodium chloride solution $(250 \mathrm{~mL})$. The washed organic solution was dried over sodium sulfate, the dried solution was filtered, and the filtrate was concentrated to give ethyl (E)-5-(triisopropylsilyl)pent-2-en-4-ynoate as a colorless oil that was used in the next step without further purification. The ${ }^{1} \mathrm{H}$ NMR data matched literature values. ${ }^{9}$

\footnotetext{
${ }^{9}$ Sohn, S. S.; Rosen, E. L.; Bode, J. W. J. Am. Chem. Soc. 2004, 126, 14370-14371.
} 
Reduction of the crude ester formed in the preceding Horner-Wadsworth-Emmons olefination reaction was performed according to the procedure reported by Bressy and coworkers. ${ }^{10}$ To a rapidly stirred solution of crude ethyl (E)-5-(triisopropylsilyl)pent-2-en-4-ynoate (theoretically $110 \mathrm{mmol}, 1$ equiv) in ethyl ether $(220 \mathrm{~mL})$ was added diisobutyl aluminum hydride (1.0 M solution in hexane, $243 \mathrm{~mL}, 2.2$ equiv) by cannula at $-78^{\circ} \mathrm{C}$. The mixture was stirred at $78{ }^{\circ} \mathrm{C}$ for $1 \mathrm{~h}$, then at $0{ }^{\circ} \mathrm{C}$ for $1.5 \mathrm{~h}$. The reaction mixture was then transferred by wide-bore cannula to a 2-L round-bottomed flask containing a rapidly stirred aqueous Rochelle salt solution (potassium sodium tartrate, $0.80 \mathrm{M}, 410 \mathrm{~mL}, 328 \mathrm{mmol}, 3.0$ equiv) pre-chilled to $0{ }^{\circ} \mathrm{C}$. A cloudy slurry formed immediately upon aqueous quenching of the reaction mixture; after approximately 3 min of stirring at $0{ }^{\circ} \mathrm{C}$, this suspension thickened to form a gel. Gas evolution was then observed, followed by gradual collapse of the gel to form a cloudy, light yellow emulsion. The mixture was stirred at $23{ }^{\circ} \mathrm{C}$ overnight under an atmosphere of nitrogen gas, during which time the emulsion separated into a biphasic mixture. The layers were separated at the end of this period, and the aqueous phase was extracted with ethyl ether $(3 \times 200 \mathrm{~mL})$. The combined organic layers were then washed with saturated aqueous sodium chloride solution $(200 \mathrm{~mL})$, and the washed organic product solution was dried over sodium sulfate. The dried solution was filtered, and the filtrate was concentrated to give a light-yellow oil. This residue was purified by flash-column chromatography (500 g silica gel, eluting with 5\% ethyl acetate-hexanes initially, grading to $10 \%$ ethyl acetate-hexanes) to afford allylic alcohol 12 as a colorless oil (19.7 g, 75\%, 3 steps). The ${ }^{1} \mathrm{H}$ NMR, ${ }^{13} \mathrm{C}$ NMR, FTIR, and HRMS data matched literature values. ${ }^{11}$

\footnotetext{
${ }^{10}$ Candy, M.; Tomas, L.; Parat, S.; Heran, V.; Bienaymé, H.; Pons, J.-M.; Bressy, C. Chem. Eur. J. 2012, 18, 1426714271.

${ }^{11}$ Cho, J.; Lee, Y. M.; Kim, D.; Kim, S. J. Org. Chem. 2009, 74, 3900-3904.
} 


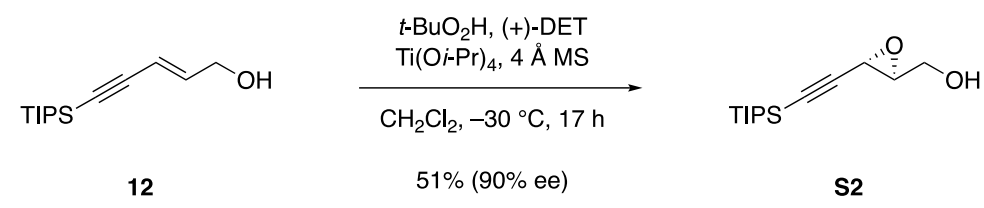

\section{Epoxyalcohol S2.}

A $250-\mathrm{mL}$ round-bottomed flask was charged with vacuum-oven-dried, powdered $4 \AA$ molecular sieves $(6.96 \mathrm{~g})$. The flask was evacuated, and the contents were flame-dried. Once cooled, the flask was back-filled with argon gas. Dichloromethane $(60 \mathrm{~mL})$ and (+)-diethyl tartrate (5.27 mL, $30.7 \mathrm{mmol}, 1.50$ equiv) were added, followed by titanium tetra-iso-propoxide ( $7.68 \mathrm{~mL}$, $26.2 \mathrm{mmol}, 1.28$ equiv). The resulting mixture was chilled to $-20{ }^{\circ} \mathrm{C}$ and stirring was maintained at that temperature for $1 \mathrm{~h}$ to ensure thermal equilibration. A solution of allylic alcohol $12(4.88 \mathrm{~g}$, $20.5 \mathrm{mmol}, 1$ equiv) in dichloromethane $(60 \mathrm{~mL})$ was then added by syringe, and the mixture was stirred at $-20{ }^{\circ} \mathrm{C}$ for $30 \mathrm{~min}$. Next, a solution of tert-butyl hydroperoxide (5-6 M solution in decane, $11.2 \mathrm{~mL}, 60 \mathrm{mmol}, 3$ equiv) was added dropwise over $10 \mathrm{~min}$ at $-20^{\circ} \mathrm{C}$. After $17 \mathrm{~h}$, TLC analysis (30\% ethyl acetate-hexanes, $\left.\mathrm{UV}+\mathrm{KMnO}_{4}\right)$ indicated that no olefin starting material remained. Ice-cold aqueous DL-tartaric acid solution $(10 \% \mathrm{w} / \mathrm{v}, 120 \mathrm{~mL})$ was added, and the resulting mixture was stirred at $-20{ }^{\circ} \mathrm{C}$ for 30 min before it was allowed to warm to $23{ }^{\circ} \mathrm{C}$ over 1 h. The warmed mixture was transferred to a separatory funnel containing dichloromethane (100 $\mathrm{mL})$. The layers were gently shaken and were then separated. The aqueous phase was extracted with fresh dichloromethane $(3 \times 100 \mathrm{~mL})$. The combined extracts were washed with brine $(100$ $\mathrm{mL}$ ), dried over sodium sulfate, and concentrated under reduced pressure to give a cloudy, colorless oil. This material was purified by flash-column chromatography (120 $\mathrm{g}$ silica gel, eluting with 5\% ethyl acetate-hexanes initially; grading to $20 \%$ ethyl acetate-hexanes) to provide epoxyalcohol S2 as a colorless oil (2.63 g, 51\%, 90\% ee). 
The TLC $\mathrm{R}_{f},{ }^{1} \mathrm{H}$ NMR, ${ }^{13} \mathrm{C}$ NMR, FTIR, and HRMS data matched those of the enantiomer, S3, catalogued below. Enantiomeric excess was determined by conversion of epoxyalcohol S2 to the corresponding Mosher ester according to the same procedure described below for optical purity analysis of S3. 

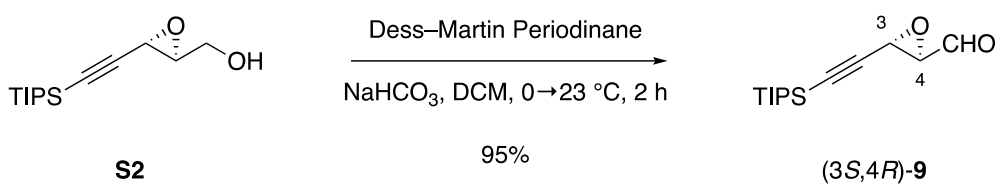

\section{Epoxyaldehyde (3S,4R)-9.}

Oxidation of alcohol $\mathbf{S 2}$ was performed according to a procedure described by Fürstner and co-workers. ${ }^{12}$ In a 100-mL round-bottomed flask, epoxyalcohol S2 was dissolved in dichloromethane $(6.64 \mathrm{~mL})$. This solution was chilled to $0{ }^{\circ} \mathrm{C}$ before solid sodium bicarbonate (558 mg, $6.64 \mathrm{mmol}, 10.0$ equiv) was added. The resulting suspension was stirred at $0{ }^{\circ} \mathrm{C}$ for 30 min before Dess-Martin periodinane (423 mg, $0.996 \mathrm{mmol}, 1.50$ equiv) was added. The mixture was removed from the cooling bath and was allowed to warm to $23^{\circ} \mathrm{C}$ gradually. After $2 \mathrm{~h}$, TLC analysis (40\% ethyl acetate-hexanes, PAA) indicated that no epoxyalcohol starting material remained. The mixture was again cooled to $0{ }^{\circ} \mathrm{C}$ before saturated aqueous sodium bicarbonate solution $(3 \mathrm{~mL})$ was added dropwise, followed by saturated aqueous sodium thiosulfate solution $(3 \mathrm{~mL})$. The mixture was stirred at $0{ }^{\circ} \mathrm{C}$ for $15 \mathrm{~min}$ before stirring was discontinued and the layers were separated. The aqueous phase was extracted with dichloromethane $(3 \times 6 \mathrm{~mL})$. The combined organic extracts were washed sequentially with 1:1 saturated aqueous sodium bicarbonatesaturated aqueous sodium thiosulfate solution $(10 \mathrm{~mL})$, then with brine. The washed organic solution was dried over sodium sulfate, filtered, and concentrated to provide a milky oil. The crude residue was purified by flash-column chromatography $(4 \mathrm{~g}$ silica gel, eluting with 5\% ethyl acetate-hexanes initially; grading to $20 \%$ ethyl acetate-hexanes) to provide epoxyaldehyde (3S,4R)-9 as a colorless oil (159 mg, 95\%). The TLC $\mathrm{R}_{f},{ }^{1} \mathrm{H}$ NMR, ${ }^{13} \mathrm{C}$ NMR, FTIR, and HRMS data matched those of the enantiomer, $(3 R, 4 S)-9$, catalogued below.

\footnotetext{
${ }^{12}$ Fürstner, A.; Flügge, S.; Larionov, O.; Takahashi, Y.; Kubota, T.; Kobayashi, J. Chem. Eur. J. 2009, 15, 40114029 .
} 


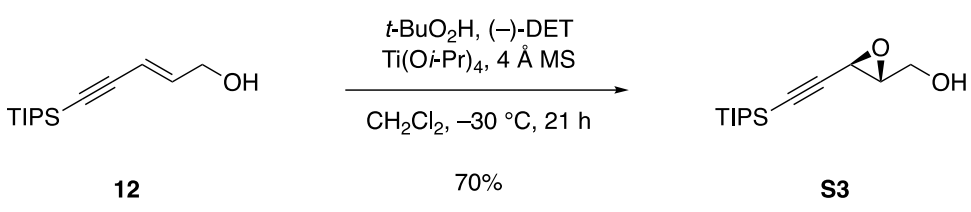

\section{Epoxyalcohol S3.}

Sharpless asymmetric epoxidation was performed according to a procedure adapted from the report of Kim and co-workers. ${ }^{111}$ A 1-L, 2-necked round-bottomed flask was oven-dried. Once cooled, the flask was charged with a magnetic stir bar and powdered $4-\AA$ molecular sieves (20.0 g, Sigma-Aldrich, activated by heating overnight in a vacuum drying oven $\left[200{ }^{\circ} \mathrm{C}, \sim 70\right.$ Torr]). A thermocouple probe was fitted to one neck of the flask, while the other neck was sealed with a rubber septum. Dichloromethane $(229 \mathrm{~mL})$ was added, and the resulting slurry was cooled to $-30^{\circ} \mathrm{C}$ in a CryoCool bath. (-)-Diethyl-D-tartrate $(7.21 \mathrm{~mL}, 41.9 \mathrm{mmol}, 0.500$ equiv) was added. Titanium tetra-iso-propoxide ( $9.83 \mathrm{~mL}, 33.6 \mathrm{mmol}, 0.400$ equiv) was then added dropwise over 2 min, causing the internal temperature to rise to $-26{ }^{\circ} \mathrm{C}$ briefly. The resulting mixture was stirred at $-30{ }^{\circ} \mathrm{C}$ for $20 \mathrm{~min}$, after which time a solution of allylic alcohol $12(20.0 \mathrm{~g}, 84.0 \mathrm{mmol}, 1$ equiv) in dichloromethane $(295 \mathrm{~mL})$ was added slowly by cannula over $10 \mathrm{~min}$. The mixture was incubated at $-30{ }^{\circ} \mathrm{C}$ for $30 \mathrm{~min}$. tert-Butylhydroperoxide solution (TBHP, 5.5 M solution in decane, $30.5 \mathrm{~mL}, 170 \mathrm{mmol}, 2.0$ equiv) was finally added at a rate of $2.0 \mathrm{~mL} / \mathrm{min}$ with a syringe pump, such that the internal temperature of the mixture did not rise above $-28{ }^{\circ} \mathrm{C}$. Stirring was maintained at $-30{ }^{\circ} \mathrm{C}$ following the addition of TBHP, and progress was monitored by TLC $(10 \%$ ethyl acetate-dichloromethane, UV+PAA). After $21 \mathrm{~h}$, the reaction was judged to be complete. A solution comprising iron(II) sulfate heptahydrate ( $27 \mathrm{~g}, 97 \mathrm{mmol}, 1.2$ equiv), DL-tartaric acid (62 $\mathrm{g}, 0.41 \mathrm{~mol}, 4.9$ equiv), and water $(517 \mathrm{~mL})$ was added to the reaction mixture, and the resulting biphasic mixture was stirred at $0{ }^{\circ} \mathrm{C}$ for 10 min at a moderate stir rate $(350 \mathrm{rpm})$ The mixture was 
then transferred to a separatory funnel where the layers were separated. The aqueous phase was extracted with ethyl ether $(3 \times 300 \mathrm{~mL})$, and the combined organic layers were washed with saturated aqueous sodium chloride solution $(2 \times 200 \mathrm{~mL})$. The washed organic solution was dried over sodium sulfate, the dried solution was filtered, and the filtrate was concentrated to give a slightly cloudy colorless oil. This residue was purified by flash-column chromatography (800 g silica gel, eluting with $5 \%$ ethyl acetate-hexanes initially, grading to $15 \%$ ethyl acetate-hexanes) to give epoxyalcohol $\mathbf{S 3}$ as a colorless, viscous oil (14.9 g, 70\%). The ${ }^{1} \mathrm{H}$ NMR, ${ }^{13} \mathrm{C}$ NMR, FTIR, and HRMS data matched reported values. ${ }^{11}$

The enantiomeric excess was determined by conversion to the corresponding Mosher esters. In this procedure, a solution of epoxyalcohol S3 (10 mg, $39 \mu \mathrm{mol}, 1$ equiv) in 4:1 dichloromethane-pyridine $(200 \mu \mathrm{L})$ was treated with $(R)-3,3,3$-trifluoro-2-methoxy-2phenylpropanoyl chloride $\left(8.8 \mu \mathrm{L}, 47 \mu \mathrm{mol}, 1.2\right.$ equiv) at $23{ }^{\circ} \mathrm{C}$. The mixture was stirred at $23{ }^{\circ} \mathrm{C}$ for $30 \mathrm{~min}$, at which point TLC analysis (50\% ethyl acetate-hexanes, $\left.\mathrm{UV}+\mathrm{KMnO}_{4}\right)$ indicated complete consumption of starting material. The reaction mixture was concentrated, and the crude residue was subjected to ${ }^{1} \mathrm{H} \mathrm{NMR}$ analysis $\left(600 \mathrm{MHz}, \mathrm{CDCl}_{3}\right)$. Integration of the major methylene resonance at $\delta 4.60(\mathrm{dd}, J=12.3,3.2 \mathrm{~Hz}, 1 \mathrm{H})$ relative to its minor diastereomeric counterpart at $\delta$ $4.66(\mathrm{dd}, J=12.5,3.0 \mathrm{~Hz}, 1 \mathrm{H}$, derived from undesired $(2 S, 3 S)$-product enantiomer) demonstrated an enantiomeric ratio of 94:6 (88\% ee). Use of the enantiomeric ( $S$ )-Mosher acyl chloride reagent gave the same result. 

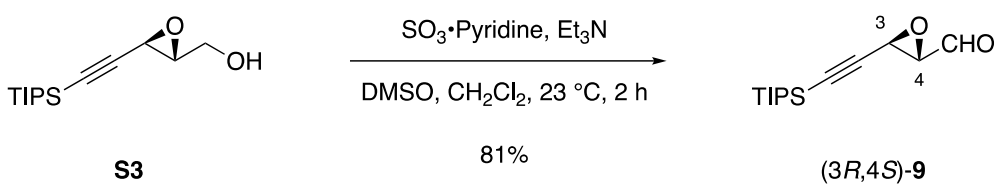

\section{Epoxyaldehyde (3R,4S)-9.}

A solution of epoxyalcohol $\mathbf{S 3}$ (14.9 g, $58.6 \mathrm{mmol}, 1$ equiv) in dichloromethane (468 mL) and anhydrous dimethyl sulfoxide $(117 \mathrm{~mL})$ was treated with triethylamine $(65.3 \mathrm{~mL}, 468 \mathrm{mmol}$, 8.00 equiv). Sulfur trioxide-pyridine complex ( $37.3 \mathrm{~g}, 234 \mathrm{mmol}, 4.00$ equiv) was then added in three portions over $15 \mathrm{~min}$ at $23{ }^{\circ} \mathrm{C}$. The resulting salmon-pink solution was stirred at $23{ }^{\circ} \mathrm{C}$, and after $2 \mathrm{~h}$, TLC analysis (30\% ethyl acetate-hexanes, PAA) indicated complete consumption of starting material. The reaction mixture was transferred to a separatory funnel containing $1.2 \mathrm{~L}$ of $0.5 \mathrm{M}$ copper(II) sulfate solution. The layers were shaken, then separated, and the aqueous phase was extracted with dichloromethane $(3 \times 300 \mathrm{~mL})$. The combined organic layers were then washed with saturated aqueous sodium chloride solution $(200 \mathrm{~mL})$, and the washed organic product solution was dried over sodium sulfate. The dried solution was filtered, and the filtrate was concentrated to give a brown oil. This residue was purified by flash-column chromatography (600 g silica gel, eluting with 5\% ethyl acetate-hexanes initially, grading to 10\% ethyl acetate-hexanes) to afford $(3 R, 4 S)-\mathbf{9}$ as a colorless oil $(12.0 \mathrm{~g}, 81 \%)$.

$\mathrm{R}_{f}=0.57$ (40\% ethyl acetate-hexanes, $\mathrm{KMnO}_{4}$ ).

${ }^{1} \mathrm{H}$ NMR (500 MHz, $\left.\mathrm{CDCl}_{3}\right): \delta 9.02(\mathrm{~d}, J=6.1 \mathrm{~Hz}, 1 \mathrm{H}), 3.69(\mathrm{~d}, J=1.8 \mathrm{~Hz}, 1 \mathrm{H}), 3.54(\mathrm{dd}, J=$ 6.1, $1.8 \mathrm{~Hz}, 1 \mathrm{H}), 1.07(\mathrm{~s}, 21 \mathrm{H})$.

${ }^{13} \mathrm{C} \mathrm{NMR}\left(100 \mathrm{MHz}, \mathrm{CDCl}_{3}\right): \delta 196.3,99.9,88.9,60.5,44.2,18.6,11.2$. 
FTIR (neat, $\mathrm{cm}^{-1}$ ): 2944 (s), 2866 (s), 1733 (s), 1463 (m), 1411 (m), 1046 (m), 883 (m), 833 (m), $667(\mathrm{~m})$.

HRMS (ESI+, $m / z):[\mathrm{M}+\mathrm{H}]^{+}$calc'd for $\mathrm{C}_{14} \mathrm{H}_{24} \mathrm{O}_{2} \mathrm{Si}, 252.1542$; found 252.1540 . 


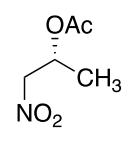

15

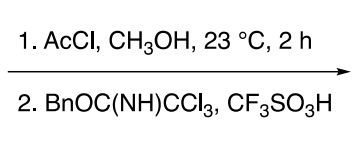

$66 \%(\geq 99 \%$ ee)

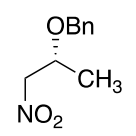

10

\section{Nitro compound 10.}

Acetyl chloride (123 mL, $1.73 \mathrm{~mol}, 12.8$ equiv) was added dropwise over $15 \mathrm{~min}$ to a solution of $(R)$-1-nitropropan-2-yl acetate $(\mathbf{1 5}, 20.0 \mathrm{~g}, 136 \mathrm{mmol}, 1 \text { equiv })^{13}$ in methanol (1.23 L) at $0{ }^{\circ} \mathrm{C}$. Following the addition of acetyl chloride, the mixture was allowed to warm to $23{ }^{\circ} \mathrm{C}$; progress was monitored by TLC (40\% ethyl acetate-hexanes, $\mathrm{KMnO}_{4}$ ). After $2 \mathrm{~h}$, complete consumption of starting material was noted, and the mixture was concentrated by rotary evaporation to obtain $(R)$-1-nitropropan-2-ol as a faint yellow oil. Residual methanol present in the crude product was removed by azeotropic removal of benzene. The crude product thus obtained was used in the next step without further purification.

To a solution of $(R)$-1-nitropropan-2-ol (theoretically $136 \mathrm{mmol}$ ) in 1:2 dichloromethanehexane (412 mL) was added benzyl 2,2,2-trichloroacetimidate (30.5 mL, $163 \mathrm{mmol}, 1.20$ equiv). Trifluoromethanesulfonic acid $(1.21 \mathrm{~mL}, 13.6 \mathrm{mmol}, 0.100$ equiv) was then added dropwise over 30 min at $23^{\circ} \mathrm{C}$, causing a white precipitate to appear. After $5 \mathrm{~h}$, TLC analysis (20\% ethyl acetatehexanes, $\mathrm{UV}+\mathrm{KMnO}_{4}$ ) indicated that all starting material had been consumed. The reaction mixture was filtered through a pad of Celite to remove the trichloroacetamide precipitate, and the filter pad was washed with hexanes $(2 \times 50 \mathrm{~mL})$. The filtrate was concentrated to give a muddy brown slurry, which was purified by two sequential recrystallizations from $1 \%$ ethyl acetatehexanes $(200 \mathrm{~mL})$ to give benzyl ether $\mathbf{1 0}$ as a brilliant white, fluffy powder $(17.4 \mathrm{~g}, 66 \%, 2 \mathrm{steps})$.

\footnotetext{
${ }^{13}$ Kitayama, T. Tetrahedron 1996, 52, 6139-6148.
} 
The ${ }^{1} \mathrm{H}$ NMR and melting-point data matched reported values. ${ }^{14}$ Enantiomeric excess was determined to be $\geq 99 \%$ by chiral HPLC analysis using a chiral stationary-phase AD-H column using $2 \%$ isopropanol-hexanes as eluent at a flow rate of $1.0 \mathrm{~mL} / \mathrm{min}$, with detection at $300 \mathrm{~nm}$. Major enantiomer $\mathrm{R}_{t}=14.7 \mathrm{~min}$, minor enantiomer $\mathrm{R}_{t}=11.7 \mathrm{~min}$.

${ }^{14}$ Bartoli, G.; Marcantoni, E.; Petrini, M. J. Chem. Soc. Chem. Commun. 1991, 793-794. 


\section{Synthesis of Isoxazoline $N$-oxides 17 and 18}

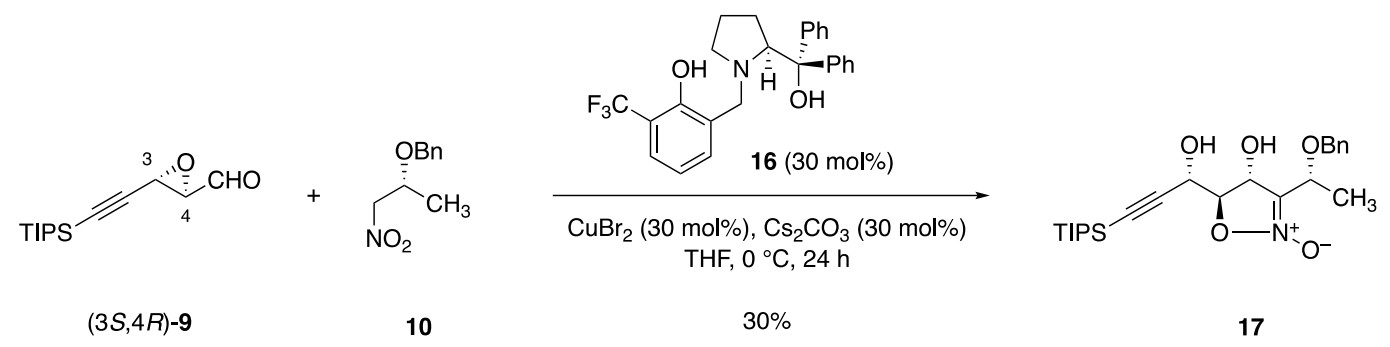

\section{Isoxazoline $N$-oxide 17.}

A 4-mL glass vial was charged with a magnetic stir bar, nitro compound $\mathbf{1 0}$ (64 mg, 0.33 mmol, 1.7 equiv), copper(II) bromide (13 mg, $59 \mu$ mol, 0.30 equiv), cesium carbonate (29mg, 89 $\mu$ mol, 0.45 equiv), and prolinol ligand 16 (25 mg, $59 \mu \mathrm{mol}, 0.30$ equiv). ${ }^{15}$ This mixture was suspended in tetrahydrofuran $(800 \mu \mathrm{L})$, the vial was sealed with a PTFE-lined screw cap, and the mixture was stirred at $23{ }^{\circ} \mathrm{C}$ for $4 \mathrm{~h}$; over this time, the mixture changed from dark black to cerulean blue. The mixture was then chilled to $0{ }^{\circ} \mathrm{C}$ before a solution of epoxyaldehyde $(3 S, 4 R)-9(50 \mathrm{mg}$, $0.20 \mathrm{mmol}, 1$ equiv) in tetrahydrofuran $(100 \mu \mathrm{L})$ was added. The mixture was warmed to $4{ }^{\circ} \mathrm{C}$, and it was stirred at this temperature for $24 \mathrm{~h}$, until TLC analysis (30\% ethyl acetate-hexanes) showed complete consumption of aldehyde starting material. The mixture was neutralized with the addition of saturated aqueous ammonium chloride solution $(1.0 \mathrm{~mL})$. This mixture was then extracted with ethyl acetate $(3 \times 2 \mathrm{~mL})$; the combined organic extracts were dried over sodium sulfate, filtered, and concentrated to provide a dark green-black oil. This crude mixture was purified by flash-column chromatography (12 g silica gel, eluting with $10 \%$ ethyl acetate-hexanes initially, grading to $35 \%$ ethyl acetate-hexanes) to provide $\mathbf{1 7}$ as a white, crystalline solid (26 mg, $30 \%)$.

${ }^{15}$ Xu, K.; Lai, G.; Zha, Z.; Pan, S.; Chen, H.; Wang, Z. Chem. Eur. J. 2012, 18, 12357-12362. 
Crystals suitable for X-ray diffraction analysis were prepared by dissolving the product (20 $\mathrm{mg})$ in dichloromethane $(1 \mathrm{~mL})$. This solution was passed through a cotton plug to remove any insoluble impurities, and the filtrate was collected in a 1-mL glass vial. This vial was placed within a 20 -mL glass vial into which hexanes $(\sim 5 \mathrm{~mL})$ had been introduced. The large vial was capped, and the assembly was allowed to stand at $23^{\circ} \mathrm{C}$; after $1 \mathrm{~d}$, the hexanes in the large vial was removed by pipette, and fresh portion of hexanes $(\sim 5 \mathrm{~mL})$ was introduced. The cap to the large vial was left slightly ajar to allow slow evaporation of solvent, and after $4 \mathrm{~d}$ of standing, needle-shaped crystals had formed.

$\mathrm{R}_{f}=0.32$ (30\% ethyl acetate-hexanes, $\mathrm{UV}+\mathrm{KMnO}_{4}$ ).

${ }^{1} \mathrm{H}$ NMR $\left(500 \mathrm{MHz}, \mathrm{CDCl}_{3}\right) \delta 7.35-7.29(\mathrm{~m}, 5 \mathrm{H}), 5.60(\mathrm{~d}, J=2.5 \mathrm{~Hz}, 1 \mathrm{H}), 4.67(\mathrm{~d}, J=3.0 \mathrm{~Hz}$, $1 \mathrm{H}), 4.60(\mathrm{q}, J=6.7 \mathrm{~Hz}, 1 \mathrm{H}), 4.57(\mathrm{~d}, J=11.2 \mathrm{~Hz}, 1 \mathrm{H}), 4.45-4.43(\mathrm{~m}, 2 \mathrm{H}), 1.52(\mathrm{~d}, J=$ $6.7 \mathrm{~Hz}, 3 \mathrm{H}), 1.08(\mathrm{~s}, 21 \mathrm{H})$.

${ }^{13} \mathrm{C}$ NMR $\left(126 \mathrm{MHz}, \mathrm{CDCl}_{3}\right) \delta 137.3,128.7,128.3,128.2,119.6,102.2,89.9,84.6,75.2,72.1$, $70.3,62.6,19.1,18.7,11.2$.

FTIR (neat, $\left.\mathrm{cm}^{-1}\right)$ : 3386 (br), 2865 (m), 1636 (s), 1462 (m), 1366 (m), 1209 (m), 1088 (s), 882 (s), $676(s)$.

HRMS (ESI+, $m / z):[\mathrm{M}+\mathrm{Na}]^{+}$calc'd for $\mathrm{C}_{24} \mathrm{H}_{37} \mathrm{NO}_{5} \mathrm{Si}$, 470.2333; found 470.2321. 


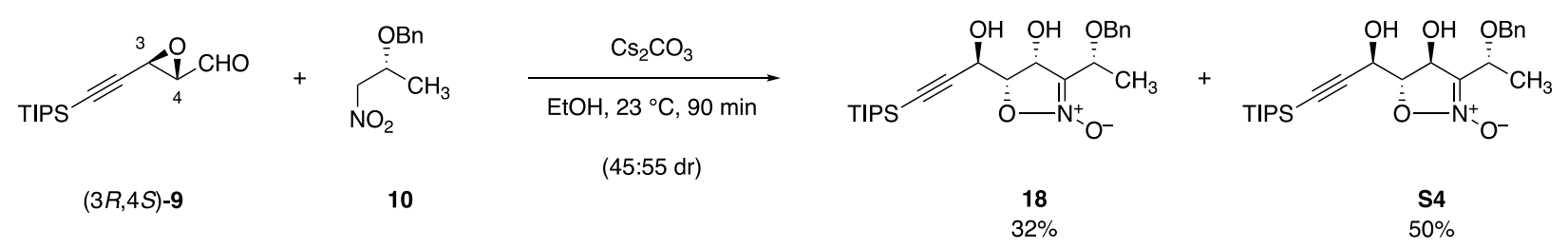

\section{Non-diastereoselective synthesis of isoxazoline $N$-oxides 18 and S4.}

In a 20-mL glass vial fitted with a magnetic stir bar, nitro compound $\mathbf{1 0}(914 \mathrm{mg}, 4.68$ mmol, 1.20 equiv) was added to a solution of epoxyaldehyde ( $3 R, 4 S)-9$ (985 mg, $3.90 \mathrm{mmol}, 1$ equiv) in ethanol (200 proof, $7.80 \mathrm{~mL}$ ). The mixture was stirred at $23{ }^{\circ} \mathrm{C}$ for $5-10 \mathrm{~min}$, until the nitro compound was fully dissolved, before cesium carbonate ( $254 \mathrm{mg}, 780 \mu \mathrm{mol}, 0.200$ equiv) was added in a single portion. The mixture immediately turned canary yellow in color. Progress was monitored by ${ }^{1} \mathrm{H}-\mathrm{NMR}$ analysis; after $90 \mathrm{~min}$, an aliquot of the reaction mixture was concentrated, re-dissolved in $\mathrm{CDCl}_{3}$ and analyzed by ${ }^{1} \mathrm{H}-\mathrm{NMR}$, revealing that no epoxy aldehyde starting material remained, and that cyclization of the intermediate nitroaldol adducts was complete. The stir bar was removed, and the reaction mixture was concentrated directly in vacuo to provide a viscous, yellow oil. This was purified by flash-column chromatography ( $80 \mathrm{~g}$ silica gel, eluting with 5\% ethyl acetate-hexanes initially, grading to $20 \%$ ethyl acetate-hexanes) to furnish, in order of elution, the undesired C5 epimer S4 (866 mg, 50\%) and the desired C5 epimer $18(560 \mathrm{mg}, 32 \%)$ as colorless oils.

\section{Compound 18:}

$\mathrm{R}_{f}=0.61$ (50\% ethyl acetate-hexanes, $\left.\mathrm{UV}+\mathrm{KMnO}_{4}\right)$.

${ }^{1} \mathrm{H}$ NMR (600 MHz, $\left.\mathrm{CDCl}_{3}\right): \delta 7.37-7.29(\mathrm{~m}, 5 \mathrm{H}), 5.14($ app t, $J=6.9 \mathrm{~Hz}, 1 \mathrm{H}), 4.77$ (app t, $J=$ $5.4 \mathrm{~Hz}, 1 \mathrm{H}), 4.66(\mathrm{~d}, J=12.1 \mathrm{~Hz}, 1 \mathrm{H}), 4.63(\mathrm{q}, J=6.7 \mathrm{~Hz}, 1 \mathrm{H}), 4.43(\mathrm{~d}, J=12.2 \mathrm{~Hz}, 1 \mathrm{H})$, 
$3.92(\mathrm{dd}, J=6.7,5.6 \mathrm{~Hz}, 1 \mathrm{H}), 3.60(\mathrm{~d}, J=7.2 \mathrm{~Hz}, 1 \mathrm{H}), 3.35(\mathrm{~d}, J=5.8 \mathrm{~Hz}, 1 \mathrm{H}), 1.49(\mathrm{~d}, J$ $=6.7 \mathrm{~Hz}, 3 \mathrm{H}), 1.09(\mathrm{br} \mathrm{s}, 21 \mathrm{H})$.

${ }^{13} \mathrm{C}$ NMR $\left(150 \mathrm{MHz}, \mathrm{CDCl}_{3}\right) \delta 162.6,138.0,128.7,128.4,127.9,119.6,103.2,89.6,79.4,77.4$, $77.2,76.9,74.7,72.8,70.8,60.4,19.1,18.7,11.2$.

FTIR: 3380 (br), 2942 (s), 2865 (s), 1630 (s), 1463 (m), 1381 (m), 1083 (s), 883 (s), 678 (s).

HRMS (ESI+, $m / z)$ : $[\mathrm{M}+\mathrm{H}]^{+}$calc'd for $\mathrm{C}_{24} \mathrm{H}_{37} \mathrm{NO}_{5} \mathrm{Si}$, 448.2514; found 448.2529 .

\section{Compound S4:}

$\mathrm{R}_{f}=0.67$ (50\% ethyl acetate-hexanes, $\mathrm{UV}+\mathrm{KMnO}_{4}$ ).

${ }^{1} \mathrm{H} \mathrm{NMR}\left(500 \mathrm{MHz}, \mathrm{CDCl}_{3}\right) \delta 7.38-7.29(\mathrm{~m}, 5 \mathrm{H}), 5.47(\mathrm{dd}, J=3.6,2.5 \mathrm{~Hz}, 1 \mathrm{H}), 4.72-4.68(\mathrm{~m}$, 2H), $4.63(\mathrm{~d}, J=11.5 \mathrm{~Hz}, 1 \mathrm{H}), 4.59(\mathrm{~d}, J=11.5 \mathrm{~Hz}, 1 \mathrm{H}), 4.47(\operatorname{app} \mathrm{t}, J=2.7 \mathrm{~Hz}, 1 \mathrm{H}), 2.85$ $(\mathrm{d}, J=5.5 \mathrm{~Hz}, 1 \mathrm{H}), 2.83(\mathrm{~d}, J=3.7 \mathrm{~Hz}, 1 \mathrm{H}), 1.45(\mathrm{~d}, J=6.6 \mathrm{~Hz}, 3 \mathrm{H}), 1.08(\mathrm{~s}, 21 \mathrm{H})$.

${ }^{13} \mathrm{C}$ NMR $\left(126 \mathrm{MHz}, \mathrm{CDCl}_{3}\right) \delta 137.3,128.8,128.3,128.2,117.9,102.0,90.0,84.1,74.5,72.0$, 70.0, 63.0, 18.7, 17.7, 11.1.

FTIR (neat, $\mathrm{cm}^{-1}$ ): 3395 (br), 2943 (s), 2866 (s), 1630 (s), 1463 (m), 1213 (m), 1089 (s), 833 (s). HRMS (ESI+, $m / z)$ : $[\mathrm{M}+\mathrm{H}]^{+}$calc'd for $\mathrm{C}_{24} \mathrm{H}_{37} \mathrm{NO}_{5} \mathrm{Si}$, 448.2514; found 448.2502. 


\section{Synthesis of Methylthiolincosamine (1)}

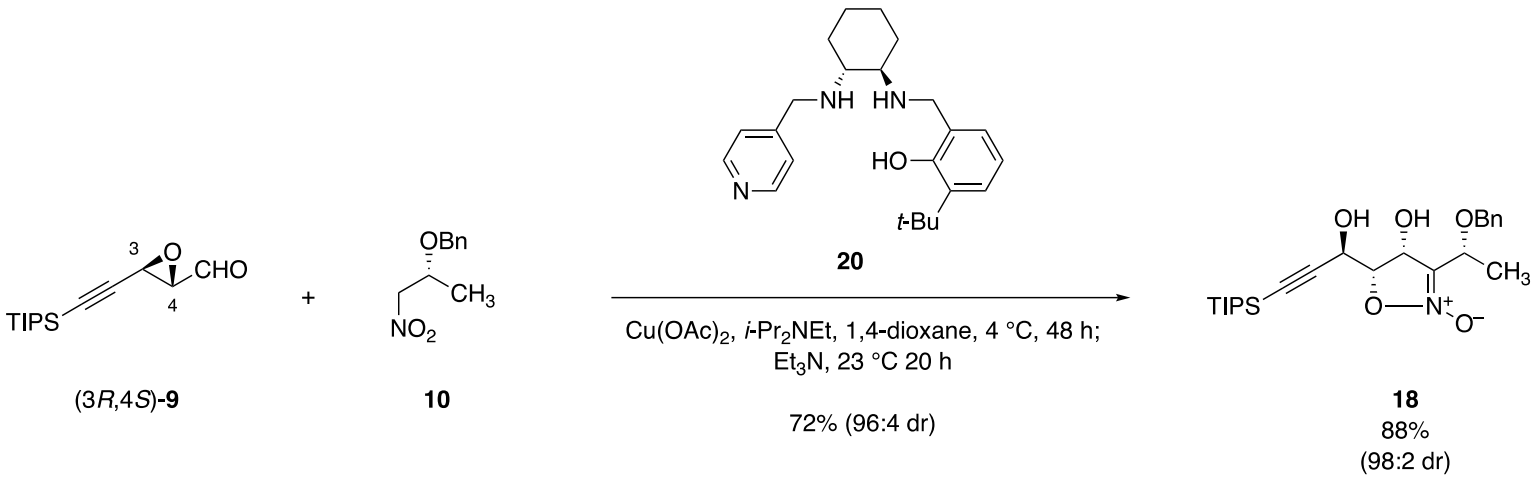

\section{Diastereoselective synthesis of isoxazoline $N$-oxide 18 .}

To a mixture of $(R, R)$-diaminocyclohexane ligand 20 (1.75 g, $47.5 \mathrm{mmol}, 0.0100$ equiv) ${ }^{16}$ and anhydrous copper(II) acetate ( $863 \mathrm{mg}, 4.75 \mathrm{mmol}, 0.0100$ equiv) was added 1,4-dioxane (47.5 $\mathrm{mL} \mathrm{mL)}$. The resulting dark forest-green solution was stirred at $23{ }^{\circ} \mathrm{C}$ for $30 \mathrm{~min}$ before $N, N$ diisopropylethylamine ( $830 \mu \mathrm{L}, 4.75 \mathrm{mmol}, 0.0100$ equiv) was added. The catalyst mixture was then stirred an additional $10 \mathrm{~min}$ at $23{ }^{\circ} \mathrm{C}$ before cooling to $5-10{ }^{\circ} \mathrm{C}$ in an ice-water bath. Nitropropane 10 (12.1 g, $61.8 \mathrm{mmol}, 1.30$ equiv) was added in one portion, followed by the epoxyaldehyde $(3 S, 4 R)-9$ (12.0 g, $47.5 \mathrm{mmol}, 1$ equiv), which was added by cannula transfer (transfer was quantitated with $2 \times 2 \mathrm{~mL} \mathrm{1,4-dioxane} \mathrm{rinses).} \mathrm{The} \mathrm{mixture} \mathrm{was} \mathrm{then} \mathrm{transferred} \mathrm{to}$ a $4{ }^{\circ} \mathrm{C}$ cold-room, where constant stirring was maintained at that temperature. ${ }^{17}$ Progress was monitored by NMR as follows: Aliquots of the reaction mixture (ca. $50 \mu \mathrm{L}$ ) were diluted with ethyl acetate $(2 \mathrm{~mL})$, and the diluted samples were washed with saturated aqueous ammonium chloride solution $(1 \mathrm{~mL})$. The washed samples were then dried by passage through a short plug of sodium sulfate $(1 \times 2 \mathrm{~cm})$, and the dried filtrate was concentrated. The green-brown residue thus

${ }^{16}$ (a) Chougnet, A.; Zhang, G.; Liu, K.; Häussinger, D.; Kägi, A.; Allmendinger, T.; Woggon, W.-D. Adv. Synth. Catal. 2011, 353, 1797-1806. (b) Zhang, G.; Yashima, E.; Woggon, W.-D. Adv. Synth. Catal. 2009, 351, 1255-1262. ${ }^{17}$ Although the melting point of pure 1,4 -dioxane is $12{ }^{\circ} \mathrm{C}$, freezing point depression prevents the solidification of the reaction mixture at these temperatures. 
obtained was analyzed by ${ }^{1} \mathrm{H}$ NMR $\left(\mathrm{CDCl}_{3}\right)$, where consumption of epoxyaldehyde was gauged relative to the triisopropylsilyl signal $(\delta 1.15-1.00,21 \mathrm{H})$. After $48 \mathrm{~h}$ at $4{ }^{\circ} \mathrm{C}$, conversion of aldehyde had reached $\geq 95 \%$, and triethylamine ( $13.3 \mathrm{~mL}, 95.0 \mathrm{mmol}, 2.00$ equiv) was added to induce cyclization. The mixture was warmed to $23{ }^{\circ} \mathrm{C}$ and stirred for $20 \mathrm{~h}$, whereupon aliquot NMR analysis (as above) showed the absence of epoxide methine resonances (ca. $\delta 3.45,3.30$ ), with concomitant formation of isoxazoline $N$-oxide products as a 98:2 diastereomeric mixture. The product mixture was poured into a separatory funnel containing $175 \mathrm{~mL}$ saturated aqueous ammonium chloride solution, and the resulting mixture was extracted with ethyl acetate $(3 \times 150$ $\mathrm{mL}$ ). The combined organic extracts were washed with saturated aqueous sodium chloride solution $(50 \mathrm{~mL})$, and the washed organic phase was dried over sodium sulfate. The dried product solution was filtered, and the filtrate was concentrated to afford crude product as a dark brown oil. This residue was purified by flash-column chromatography $(2.0 \mathrm{~kg}$ silica; eluting $10 \%$ ethyl acetatehexanes initially, grading to $30 \%$ ethyl acetate-hexanes) to afford the isoxazoline $N$-oxide $\mathbf{1 8}$ an amber-brown, viscous oil (16.4 g, 77\%). 


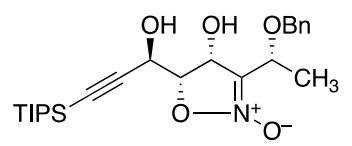

18

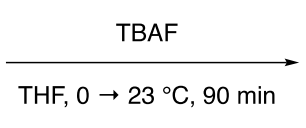

$91 \%$

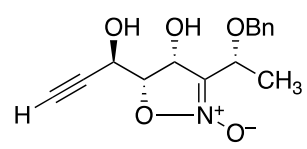

S5

\section{Propargylic alcohol S5.}

A solution of tetrabutylammonium fluoride $(1.0 \mathrm{M}$ in tetrahydrofuran, $88 \mathrm{~mL}, 88 \mathrm{mmol}$, 2.5 equiv) was added via cannula over $5 \mathrm{~min}$ to a solution of alkynyl silane $\mathbf{1 8}$ (15.8 g, $35.3 \mathrm{mmol}$, 1 equiv) in tetrahydrofuran $(118 \mathrm{~mL})$ at $0{ }^{\circ} \mathrm{C}$. The mixture was then warmed to $23{ }^{\circ} \mathrm{C}$, and after 90 min of stirring at this temperature, TLC analysis (50\% ethyl acetate-hexanes, $\left.\mathrm{UV}+\mathrm{KMnO}_{4}\right)$ indicated full conversion of starting material. The product solution was then poured into a separatory funnel containing $350 \mathrm{~mL}$ of water to which $35 \mathrm{~mL}$ of saturated aqueous sodium chloride solution had been added. The resulting biphasic mixture was extracted with ethyl acetate $(3 \times 150 \mathrm{~mL})$. The organic layers were combined, and the organic solution was washed with saturated aqueous sodium chloride solution $(100 \mathrm{~mL})$. The washed product solution was dried over sodium sulfate, and the dried solution was filtered. The filtrate was concentrated to afford crude product as a light amber oil. This residue was purified by flash-column chromatography (500 $\mathrm{g}$ silica; eluting $35 \%$ ethyl acetate-hexanes initially, grading to 50\% ethyl acetate-hexanes) to provide $\mathbf{S 5}$ as a sand-colored, powdery solid (9.38 g, 91\%).

$\mathrm{R}_{f}=0.45$ (60\% ethyl acetate-hexanes, $\left.\mathrm{UV}+\mathrm{KMnO}_{4}\right)$.

${ }^{1} \mathrm{H}$ NMR $\left(600 \mathrm{MHz}, \mathrm{CDCl}_{3}\right): \delta 7.37-7.29(\mathrm{~m}, 5 \mathrm{H}), 5.22(\mathrm{~d}, J=6.7 \mathrm{~Hz}, 1 \mathrm{H}), 4.77(\mathrm{dd}, J=6.3,2.3$ $\mathrm{Hz}, 1 \mathrm{H}), 4.61(\mathrm{q}, J=6.7 \mathrm{~Hz}, 1 \mathrm{H}), 4.60(\mathrm{~d}, J=12.2 \mathrm{~Hz}, 1 \mathrm{H}), 4.45(\mathrm{~d}, J=12.1 \mathrm{~Hz}, 1 \mathrm{H}), 4.06$ $(\operatorname{app~t}, J=6.5 \mathrm{~Hz}, 1 \mathrm{H}), 4.03($ br s, $1 \mathrm{H}), 2.59(\mathrm{~d}, J=2.2 \mathrm{~Hz}, 1 \mathrm{H}), 1.48(\mathrm{~d}, J=6.7 \mathrm{~Hz}, 3 \mathrm{H})$. 
${ }^{13} \mathrm{C}$ NMR $\left(125 \mathrm{MHz}, \mathrm{CDCl}_{3}\right): \delta$ 137.6, 128.7, 128.4, 127.9, 120.0, 80.3, 79.3, 75.7, 73.9, 72.6, $70.5,59.2,18.9$.

FTIR (neat, $\mathrm{cm}^{-1}$ ): 3373 (br), 3284 (m), 1628 (s), 1377 (m), 1085 (s), 1046 (m), 699 (m). HRMS (ESI+, $m / z)$ : $[\mathrm{M}+\mathrm{Na}]^{+}$calc'd for $\mathrm{C}_{15} \mathrm{H}_{17} \mathrm{NO}_{5}, 314.0999$; found 314.1009. 


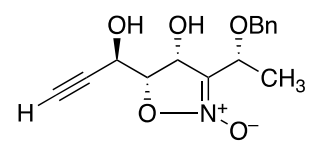

S5

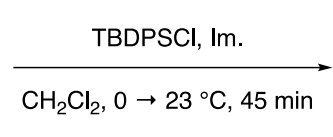

$93 \%$

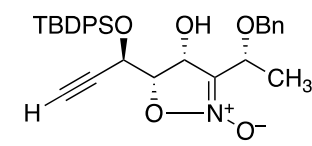

22a

tert-Butyldiphenylsilyl ether 22a.

A mixture of diol $\mathbf{S 5}$ (9.38 g, $32.2 \mathrm{mmol}, 1$ equiv) and imidazole (6.58 g, $97.0 \mathrm{mmol}, 3.00$ equiv) was dissolved in dichloromethane $(161 \mathrm{~mL})$, and the resulting solution was cooled to $0{ }^{\circ} \mathrm{C}$. tert-Butyl(chloro)diphenylsilane (12.4 mL, $48.3 \mathrm{mmol}, 1.50$ equiv) was then added in one portion, and the solution was warmed to $23{ }^{\circ} \mathrm{C}$. Within $2-5$ min of addition of the silyl chloride, a precipitate formed, imparting a cloudy appearance to the reaction mixture. Progress was monitored by TLC (60\% ethyl acetate-hexanes, $\left.\mathrm{UV}+\mathrm{KMnO}_{4}\right)$, and after $45 \mathrm{~min}$, full consumption of starting material was observed. The reaction mixture was quenched with the addition of $150 \mathrm{~mL}$ saturated aqueous sodium bicarbonate solution, and the mixture was stirred rapidly at $23{ }^{\circ} \mathrm{C}$ for $10 \mathrm{~min}$. The biphasic mixture was then extracted with dichloromethane $(3 \times 50 \mathrm{~mL})$, and the combined organic extracts were washed with brine $(50 \mathrm{~mL})$. The organic solution was then dried over sodium sulfate, and the dried solution was filtered. The filtrate was concentrated to give a peach-colored oil, which was purified by flash-column chromatography (700 g silica; eluting with hexanes initially, grading to $25 \%$ ethyl acetate-hexanes) to provide $\mathbf{2 2 a}$ as a colorless, highly viscous oil (15.8 $\mathrm{g}, 93 \%)$.

$\mathrm{R}_{f}=0.49$ (30\% ethyl acetate-hexanes, $\left.\mathrm{UV}+\mathrm{KMnO}_{4}\right)$.

${ }^{1} \mathrm{H}$ NMR (500 MHz, $\left.\mathrm{CDCl}_{3}\right): \delta$ 7.75-7.68 (m, 4H), 7.49-7.44 (m, 2H), 7.43-7.28 (m, 9H), 5.17 $(\operatorname{app~t}, J=7.6 \mathrm{~Hz}, 1 \mathrm{H}), 4.72(\mathrm{dd}, J=4.6,2.2 \mathrm{~Hz}, 1 \mathrm{H}), 4.66(\mathrm{q}, J=6.8 \mathrm{~Hz}, 1 \mathrm{H}), 4.64(\mathrm{~d}, J$ $=12.2 \mathrm{~Hz}, 1 \mathrm{H}), 4.46(\mathrm{~d}, J=12.1 \mathrm{~Hz}, 1 \mathrm{H}), 4.02(\mathrm{dd}, J=6.9,4.7 \mathrm{~Hz}, 1 \mathrm{H}), 3.59(\mathrm{~d}, J=8.3$ $\mathrm{Hz}, 1 \mathrm{H}), 2.45$ (d, $J=2.3 \mathrm{~Hz}, 1 \mathrm{H}), 1.50(\mathrm{~d}, J=6.8 \mathrm{~Hz}, 3 \mathrm{H}), 1.09$ (s, 9H). 
${ }^{13} \mathrm{C}$ NMR (125 MHz, $\left.\mathrm{CDCl}_{3}\right): \delta 138.1,136.2,136.1,132.0,131.4,130.6,130.4,128.6,128.2(2 \times$ C), $127.9,127.8,118.9,79.4,78.9,76.7,74.6,72.6,70.7,61.7,26.9,19.4,19.2$.

FTIR (neat, $\mathrm{cm}^{-1}$ ): 3367 (br), 2932 (m), 2858 (m), 1632 (s), 1428 (m), 1112 (s), 1087 (s), 701 (s). HRMS (ESI+, m/z): [M+Na] ${ }^{+}$calc'd for $\mathrm{C}_{31} \mathrm{H}_{35} \mathrm{NO}_{5} \mathrm{Si}$, 552.2177; found 552.2177. 


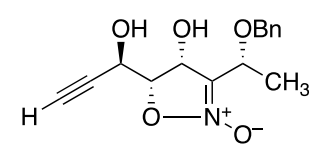

S5

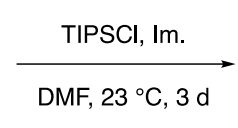

$81 \%$

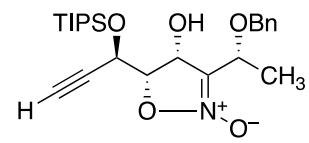

22b

\section{Triisopropylsilyl ether 22b.}

To a solution of diol S5 (329 mg, $1.13 \mathrm{mmol}, 1$ equiv) and imidazole (615 mg, $9.04 \mathrm{mmol}$, 8.00 equiv) in dimethylformamide $(11.3 \mathrm{~mL})$ was added triisopropylchlorosilane $(718 \mu \mathrm{L}, 3.39$ mmol, 3.00 equiv) in one portion at $23{ }^{\circ} \mathrm{C}$. Reaction progress was monitored by TLC (80\% ethyl acetate-hexanes, $\mathrm{UV}+\mathrm{KMnO}_{4}$ ). After $3 \mathrm{~d}$, full consumption of starting material was observed, and water $(25 \mathrm{~mL})$ was added. The resulting mixture was extracted with ethyl ether $(3 \times 25 \mathrm{~mL})$, and the combined organic extracts were washed with saturated aqueous sodium chloride solution (25 $\mathrm{mL}$ ). The washed organic solution was dried over sodium sulfate, the dried solution was filtered, and the filtrate was concentrated. The residue was purified by flash-column chromatography (24 g silica; eluting 5\% ethyl acetate-hexanes, grading to $20 \%$ ethyl acetate-hexanes) to obtain $\mathbf{2 2 b}$ as a bright white, crystalline solid (407 $\mathrm{mg}, 81 \%)$.

Crystals of 22b suitable for X-ray analysis were prepared as follows: A 1-mL vial was charged with $20 \mathrm{mg}$ of $\mathbf{2 2 \mathbf { b }}$, and a minimum quantity of benzene (ca. $50 \mu \mathrm{L}$ ) was added to dissolve this material. The sample vial was then placed inside a larger, $20-\mathrm{mL}$ scintillation vial filled with ca. $5 \mathrm{~mL}$ of hexanes, and the large vial was sealed with a screw cap. Slow diffusion of hexane into the solution of $\mathbf{2 2} \mathbf{b}$ in benzene occurred over several days at $23{ }^{\circ} \mathrm{C}$, resulting in the growth of long, needle-shaped crystals. See Appendix A for X-ray crystal structure data.

$\mathrm{R}_{f}=0.56$ (30\% ethyl acetate-hexanes, $\left.\mathrm{UV}+\mathrm{KMnO}_{4}\right)$. 
${ }^{1} \mathrm{H}$ NMR $\left(600 \mathrm{MHz}, \mathrm{CDCl}_{3}\right) \delta 7.38-7.28(\mathrm{~m}, 5 \mathrm{H}), 5.21(\mathrm{dd}, J=8.1,7.2 \mathrm{~Hz}, 1 \mathrm{H}), 4.92(\mathrm{dd}, J=4.3$, $2.3 \mathrm{~Hz}, 1 \mathrm{H}), 4.65(\mathrm{q}, J=6.8 \mathrm{~Hz}, 1 \mathrm{H}), 4.64(\mathrm{~d}, J=12.2 \mathrm{~Hz}, 1 \mathrm{H}), 4.45(\mathrm{~d}, J=12.2 \mathrm{~Hz}, 1 \mathrm{H})$, $4.08(\mathrm{~d}, J=8.2 \mathrm{~Hz}, 1 \mathrm{H}), 4.04(\mathrm{dd}, J=7.2,4.3 \mathrm{~Hz}, 1 \mathrm{H}), 2.61(\mathrm{~d}, J=2.2 \mathrm{~Hz}, 1 \mathrm{H}), 1.50(\mathrm{~d}, J$ $=6.8 \mathrm{~Hz}, 3 \mathrm{H}), 1.22-1.15(\mathrm{~m}, 3 \mathrm{H}), 1.09(\mathrm{app} \mathrm{dd}, J=7.4,5.4 \mathrm{~Hz}, 18 \mathrm{H})$.

${ }^{13} \mathrm{C} \mathrm{NMR}\left(151 \mathrm{MHz}, \mathrm{CDCl}_{3}\right) \delta 140.2,130.6,130.2,129.9,120.9,81.8,80.6,78.4,76.9,74.5,72.7$, $63.6,21.1,20.0,19.9,14.2$.

FTIR (neat, $\mathrm{cm}^{-1}$ ): 3345 (m), 3260 (m), 2939 (m), 2865 (m), 1639 (s), $1202(\mathrm{~m}), 1115$ (s), 873 (m), $816(\mathrm{~m}), 733(\mathrm{~s})$.

HRMS (ESI+, $m / z$ ): $[\mathrm{M}+\mathrm{H}]^{+}$calc'd for $\mathrm{C}_{24} \mathrm{H}_{37} \mathrm{NO}_{5} \mathrm{Si}$, 448.2514; found 448.2516 . 


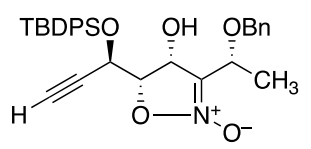

22a

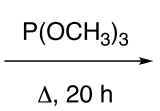

$75 \%$

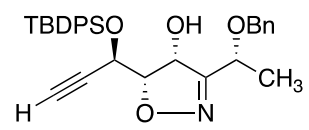

23

\section{Isoxazoline 23a.}

The procedure for isoxazoline $\mathrm{N}$-oxide deoxygenation was adapted from the report of Marotta and coworkers. ${ }^{18}$ A 500-mL round-bottomed flask was charged with isoxazoline $N$-oxide 22a (15.7 g, $29.6 \mathrm{mmol})$, and this substrate was dried by azeotropic removal of benzene. Once dried, the starting material was dissolved in trimethyl phosphite $(119 \mathrm{~mL}$; CAUTION: trimethyl phosphite is a highly malodorous, volatile substance. All operations up to and including the aqueous acid quench should be carried out in a well-ventilated fume hood.), and the flask was sealed. The mixture was heated to $100{ }^{\circ} \mathrm{C}$ in a pre-heated oil bath for $20 \mathrm{~h}$, at which point TLC analysis (30\% ethyl acetate-hexanes, UV+PAA) indicated full consumption of starting material. The solution was cooled to $23{ }^{\circ} \mathrm{C}$, and the cooled product solution was transferred to a 2-L roundbottomed flask containing $500 \mathrm{~mL}$ of ethyl ether. The product solution was cooled to $5^{\circ} \mathrm{C}$ in an ice-water bath, and the chilled mixture was treated very carefully with $1 \mathrm{~N}$ aqueous hydrochloric acid solution (100 mL, added in 1-mL portions over 30 minutes). Care was taken not to allow the internal temperature of the mixture rise above $15{ }^{\circ} \mathrm{C}$ during the acidification procedure. The acidified mixture was transferred to a separatory funnel, where the layers were separated. The organic layer was washed with $1 \mathrm{~N}$ aqueous hydrochloric acid solution $(2 \times 75 \mathrm{~mL})$. The combined aqueous washes were extracted with fresh portions of ethyl ether $(2 \times 75 \mathrm{~mL})$. The combined organic phases were then washed sequentially with half-saturated aqueous sodium chloride solution $(50 \mathrm{~mL})$, and saturated aqueous sodium chloride solution $(50 \mathrm{~mL})$. The organic layer was

\footnotetext{
${ }^{18}$ Marotta, E.; Micheloni, L. M.; Scardovi, N.; Righi, P. Org. Lett. 2001, 3, 727-729.
} 
then dried over sodium sulfate, the dried solution was filtered, and the filtrate was concentrated to afford crude product as a light-yellow oil. The crude material was purified by flash-column chromatography (700 g silica; eluting with 5\% ethyl acetate-hexanes initially, grading to $25 \%$ ethyl acetate-hexanes) to furnish $\mathbf{2 3}$ as a light peach-colored, highly viscous oil (11.5 g, 75\%).

$\mathrm{R}_{f}=0.56$ (30\% ethyl acetate-hexanes, $\left.\mathrm{UV}+\mathrm{PAA}\right)$.

${ }^{1} \mathrm{H}$ NMR $\left(600 \mathrm{MHz}, \mathrm{CDCl}_{3}\right): \delta$ 7.79-7.76 (m, 4H), 7.50-7.46 (m, 2H), 7.44-7.41 (m, 4H), 7.37$7.34(\mathrm{~m}, 4 \mathrm{H}), 7.32-7.29(\mathrm{~m}, 1 \mathrm{H}), 5.28($ app t, $J=8.3 \mathrm{~Hz}, 1 \mathrm{H}), 4.88(\mathrm{dd}, J=4.0,2.3 \mathrm{~Hz}$, $1 \mathrm{H}), 4.58(\mathrm{q}, J=6.8 \mathrm{~Hz}, 1 \mathrm{H}), 4.56(\mathrm{~d}, J=12.3 \mathrm{~Hz}, 1 \mathrm{H}), 4.53(\mathrm{~d}, J=12.0 \mathrm{~Hz}, 1 \mathrm{H}), 4.23(\mathrm{~d}$, $J=8.2,4.0 \mathrm{~Hz}, 1 \mathrm{H}), 4.15(\mathrm{~d}, J=8.6 \mathrm{~Hz}, 1 \mathrm{H}), 2.48(\mathrm{~d}, J=2.3 \mathrm{~Hz}, 1 \mathrm{H}), 1.59(\mathrm{~d}, J=6.8 \mathrm{~Hz}$, $3 \mathrm{H}), 1.10(\mathrm{~s}, 9 \mathrm{H})$.

${ }^{13} \mathrm{C}$ NMR (150 MHz, $\left.\mathrm{CDCl}_{3}\right): \delta 161.3,137.5,136.3,136.2,132.1,131.3,130.5,130.2,128.5$, $128.0,127.9,127.7,83.4,80.1,76.0,71.2,70.9,62.6,26.9,20.0,19.4$.

FTIR (neat, $\mathrm{cm}^{-1}$ ): 3471 (br), 2932 (m), 2858 (m), 1428 (m), 1086 (s), 907 (m), 608 (s). HRMS (ESI+, m/z): $[\mathrm{M}+\mathrm{H}]^{+}$calc'd for $\mathrm{C}_{31} \mathrm{H}_{35} \mathrm{NO}_{4} \mathrm{Si}$, 514.2408; found 514.2424. 


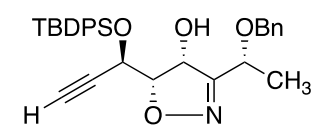

23
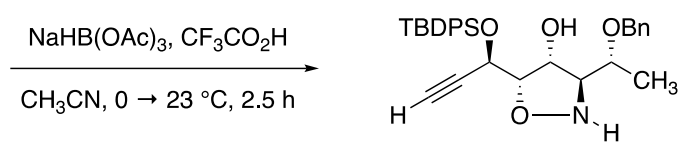

S6

\section{Isoxazolidine S6.}

The procedure for isoxazoline reduction was adapted from the report of Bauder. ${ }^{19} \mathrm{~A}$ mixture of isoxazoline $\mathbf{2 3}$ (11.4 g, $22.1 \mathrm{mmol}, 1$ equiv) and sodium triacetoxyborohydride (23.4 g, $110 \mathrm{mmol}, 5.00$ equiv) was suspended in anhydrous acetonitrile $(184 \mathrm{~mL})$. The resulting milkywhite suspension was cooled to $0{ }^{\circ} \mathrm{C}$ in an ice-water bath with constant stirring, and to the cooled suspension was added trifluoroacetic acid (170 mL, $2.21 \mathrm{~mol}, 100$ equiv) over $10 \mathrm{~min}$ via an ovendried pressure-equalizing addition funnel. Addition of trifluoroacetic acid caused the suspension to resolve into a colorless solution; following this addition, the ice-water bath was removed, and the reaction solution was allowed to warm to $23{ }^{\circ} \mathrm{C}$. Progress was monitored by TLC (30\% ethyl acetate-hexanes, UV+PAA), and after $2.5 \mathrm{~h}$, starting material was fully consumed. The mixture was cooled to $0{ }^{\circ} \mathrm{C}$, and was then transferred via cannula to a stirred, ice-cold mixture of dichloromethane $(300 \mathrm{~mL})$ and $2 \mathrm{~N}$ aqueous sodium hydroxide solution $(1.10 \mathrm{~L}, 2.21 \mathrm{~mol})$. The resulting biphasic mixture was stirred rapidly for $10 \mathrm{~min}$. Additional sodium hydroxide solution was added as necessary, until the aqueous phase attained $\mathrm{pH}>8$. The mixture was then transferred to a separatory funnel, and the layers were separated. The aqueous layer was extracted with dichloromethane $(3 \times 300 \mathrm{~mL})$, and the combined organic extracts were washed with brine $(300$ $\mathrm{mL}$ ). The washed organic layer was dried over sodium sulfate, the dried solution was filtered, and the filtrate was concentrated to afford crude isoxazolidine product as a colorless oil. This material was used in the next step without further purification.

\footnotetext{
${ }^{19}$ Bauder, C. Org. Biomol. Chem. 2008, 6, 2952-2960.
} 
For characterization purposes, a small quantity (ca. $25 \mathrm{mg}$ ) of crude residue was purified by HPLC (eluting with $0.1 \%$ trifluoroacetic acid-25\% acetonitrile-water, grading to $0.1 \%$ trifluoroacetic acid-95\% acetonitrile-water over $45 \mathrm{~min}$, with a flow rate of $15 \mathrm{~mL} / \mathrm{min}$; monitored by $\mathrm{UV}$ absorbance at $254 \mathrm{~nm}$; product $\mathrm{R}_{t}=33.5 \mathrm{~min}$ ). The trifluoroacetic acid salt thus obtained (S6 $\cdot \mathrm{CF}_{3} \mathrm{CO}_{2} \mathrm{H}$ ) exhibited the following spectral properties:

${ }^{1} \mathrm{H}$ NMR (600 MHz, $\left.\mathrm{CDCl}_{3}\right) \delta$ 7.76-7.69 (m, 4H), 7.48-7.43 (m, 2H), 7.42-7.28 (m, 9H), 4.91 (dd, $J=5.1,2.8 \mathrm{~Hz}, 1 \mathrm{H}), 4.74(\mathrm{dd}, J=4.9,2.2 \mathrm{~Hz}, 1 \mathrm{H}), 4.66(\mathrm{~d}, J=11.5 \mathrm{~Hz}, 1 \mathrm{H}), 4.40(\mathrm{~d}$, $J=11.6 \mathrm{~Hz}, 1 \mathrm{H}), 3.98(\operatorname{app~t}, J=5.0 \mathrm{~Hz}, 1 \mathrm{H}), 3.81(\mathrm{~m}, 1 \mathrm{H}), 3.51($ app t $, J=3.3 \mathrm{~Hz}, 1 \mathrm{H})$, $2.40(\mathrm{~d}, J=2.2 \mathrm{~Hz}, 1 \mathrm{H}), 1.39(\mathrm{~d}, J=6.2 \mathrm{~Hz}, 3 \mathrm{H}), 1.09$ (s, 9H).

${ }^{13} \mathrm{C}$ NMR $\left(126 \mathrm{MHz}, \mathrm{CDCl}_{3}\right): \delta 137.6,136.2,136.1,132.2,131.7,130.5,130.3,128.8,128.2$, $128.1,128.0,127.7,86.1,80.4,76.1,75.4,73.9,70.9,70.7,62.1,26.9,19.4,16.7$. Trifluoroacetate carbons were not resolved due to ${ }^{19} \mathrm{~F}$ nuclear coupling.

FTIR (neat, cm ${ }^{-1}$ ): 3302 (br), 2932 (m), 2859 (m), 1671 (s), 1428 (m), 1199 (m), 1113 (s), 701 (s). HRMS (ESI+, $m / z)$ : $[\mathrm{M}+\mathrm{Na}]^{+}$calc'd for $\mathrm{C}_{31} \mathrm{H}_{37} \mathrm{NO}_{4} \mathrm{Si}$, 538.2384; found 538.2385. 


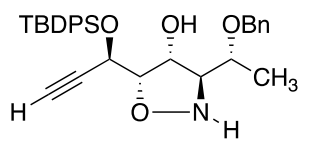

S6

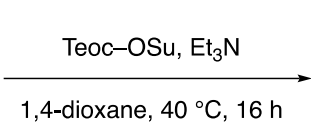

$73 \%(2$ steps $)$

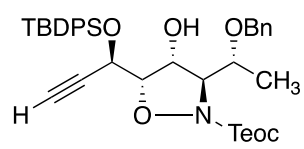

24

\section{Alkynol 24.}

A 200-mL round-bottomed flask was charged with isoxazolidine S6 (crude product from the preceding directed reduction step, theoretically $22.1 \mathrm{mmol}$ ). The starting material was dissolved in 1,4-dioxane $(55 \mathrm{~mL})$ and to the resulting solution, triethylamine $(15.4 \mathrm{~mL}, 110 \mathrm{mmol}$, 5.00 equiv) and $\mathrm{N}$-[2-(trimethylsilyl)ethoxycarbonyloxy]succinimide (Teoc-OSu, $8.59 \mathrm{~g}, 33.1$ mmol, 1.50 equiv) were added sequentially. The reaction mixture was heated to $40{ }^{\circ} \mathrm{C}$, and consumption of starting material was monitored by LCMS. After $16 \mathrm{~h}$, the reaction was judged to be complete. The reaction mixture was then diluted in $450 \mathrm{~mL}$ of ethyl acetate, and the diluted product solution was washed with saturated aqueous ammonium chloride solution $(3 \times 50 \mathrm{~mL})$. The combined aqueous washes were extracted with a portion of fresh ethyl acetate $(100 \mathrm{~mL})$, and the combined organic layers were then washed with saturated aqueous sodium chloride solution $(50 \mathrm{~mL})$. The washed organic product solution was dried over sodium sulfate, the dried solution was filtered, and the filtrate was concentrated to give a viscous orange oil. This material was purified by flash-column chromatography $(1.00 \mathrm{~kg}$ silica gel, eluting with $5 \%$ ethyl acetatehexanes initially, grading to $20 \%$ ethyl acetate-hexanes) to provide $\mathbf{2 4}$ as a highly viscous, colorless oil (10.6 g, 73\%, 2 steps).

$\mathrm{R}_{f}=0.43$ (20\% ethyl acetate-hexanes, UV+KMnO4).

${ }^{1} \mathrm{H}$ NMR (600 MHz, $\left.\mathrm{CDCl}_{3}\right): \delta 7.78-7.74(\mathrm{~m}, 4 \mathrm{H}), 7.48-7.44(\mathrm{~m}, 2 \mathrm{H}), 7.42-7.36(\mathrm{~m}, 4 \mathrm{H}), 7.35-$ $7.27(\mathrm{~m}, 5 \mathrm{H}), 4.90(\operatorname{app~t}, \mathrm{J}=3.8 \mathrm{~Hz}, 1 \mathrm{H}), 4.79(\mathrm{dd}, \mathrm{J}=6.2,2.2 \mathrm{~Hz}, 1 \mathrm{H}), 4.67$ (d, J = 11.8 
$\mathrm{Hz}, 1 \mathrm{H}), 4.48(\mathrm{~d}, \mathrm{~J}=11.8 \mathrm{~Hz}, 1 \mathrm{H}), 4.25-4.12(\mathrm{~m}, 4 \mathrm{H}), 3.65(\operatorname{app} \mathrm{p}, \mathrm{J}=6.3 \mathrm{~Hz}, 1 \mathrm{H}), 3.31$ $(\mathrm{d}, \mathrm{J}=3.9 \mathrm{~Hz}, 1 \mathrm{H}), 2.36(\mathrm{~d}, \mathrm{~J}=2.2 \mathrm{~Hz}, 1 \mathrm{H}), 1.33(\mathrm{~d}, \mathrm{~J}=6.2 \mathrm{~Hz}, 3 \mathrm{H}), 1.10(\mathrm{~s}, 9 \mathrm{H}), 1.05-$ $0.94(\mathrm{~m}, 2 \mathrm{H}), 0.04(\mathrm{~s}, 9 \mathrm{H})$.

${ }^{13} \mathrm{C} \mathrm{NMR}\left(125 \mathrm{MHz}, \mathrm{CDCl}_{3}\right): \delta 158.2,138.3,136.3,136.0,130.3,130.2,128.5,127.9(2 \times \mathrm{C})$, $127.8,127.6,83.9,81.2,75.7,74.7,74.1,73.5,71.4,64.9,62.1,26.9,19.4,17.7,17.0,1.4$. FTIR (neat, $\mathrm{cm}^{-1}$ ): 3463 (br), 2954 (m), $2858(\mathrm{~m}), 1702$ (m), 1325 (m), $1112(\mathrm{~s}), 1064$ (s), 838 (s), $700(\mathrm{~s})$.

HRMS (ESI+, m/z): $[\mathrm{M}+\mathrm{H}]^{+}$calc'd for $\mathrm{C}_{37} \mathrm{H}_{49} \mathrm{NO}_{6} \mathrm{Si}_{2}, 660.3171$; found 660.3161 . 


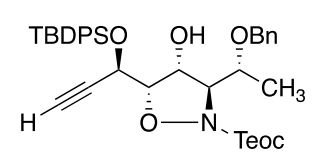

24

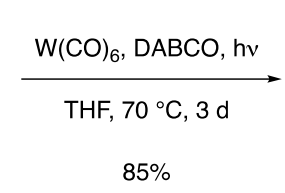

$85 \%$

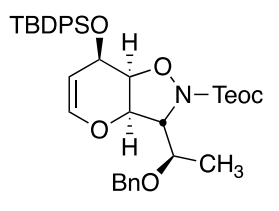

25

\section{Glycal 25.}

The procedure for tungsten-catalyzed cycloisomerization was adapted from the reports of McDonald and Koo. ${ }^{20}$ In a 200-mL round-bottomed flask, alkynol 24 (4.17 g, $6.32 \mathrm{mmol}, 1$ equiv) was dried by azeotropic removal of benzene under vacuum. The flask was back-filled with argon, and tungsten hexacarbonyl (556 mg, $1.58 \mathrm{mmol}, 0.250$ equiv), ${ }^{21}$ 1,4-diazabicyclo[2.2.2]octane (DABCO, $1.42 \mathrm{~g}, 12.6 \mathrm{mmol}, 2.00$ equiv), and degassed, anhydrous tetrahydrofuran (63.2 $\mathrm{mL}$ ) were then added sequentially (CAUTION: tungsten hexacarbonyl is a volatile source of metal and of carbon monoxide. Manipulations of this reagent should be conducted within a well-ventilated fume hood.). The flask was fitted with an oven-dried reflux condenser, and the apparatus was transferred to a pre-heated oil bath $\left(70{ }^{\circ} \mathrm{C}\right)$ positioned inside a photochemistry safety cabinet. A positive pressure of dry argon was maintained via tubing connected to an argon-filled balloon placed outside of the lightbox. The reaction mixture was refluxed with constant UV irradiation from an adjacent 200-Watt mercury-vapor bulb filtered through a water-cooled Pyrex glass jacket (CAUTION: Exposure to high-intensity UV light can cause irreversible vision loss. Never open the safety cabinet when the UV lamp is on.). Progress was monitored by TLC (20\% ethyl acetatehexanes, $\mathrm{UV}+\mathrm{KMnO}_{4}$ ). After $3 \mathrm{~d}$, full consumption of the alkynol substrate was achieved, and the crude product mixture was concentrated under a stream of dry nitrogen. The canary-yellow residue

\footnotetext{
${ }^{20}$ Koo, B.-S.; McDonald, F. E. Org. Lett. 2007, 9, 1737-1740.

${ }^{21}$ Tungsten hexacarbonyl purchased from Strem (99\%, <0.3\% molybdenum) gave moderately higher yields than precatalyst purchased from Sigma-Aldrich (97\%), likely due to the presence of molybdenum hexacarbonyl as a major impurity in the latter sample.
} 
was purified by flash-column chromatography (eluting with hexanes initially, grading to $20 \%$ ethyl acetate-hexanes) to provide $\mathbf{2 5}$ as a viscous, colorless oil (3.53 g, 85\%).

$\mathrm{R}_{f}=0.65$ (20\% ethyl acetate-hexanes, $\mathrm{UV}+\mathrm{KMnO}_{4}$ )

${ }^{1} \mathrm{H}$ NMR (500 MHz, CDCl $)$ : 7.77-7.74 (m, 2H), 7.70-7.67 (m, 2H), 7.44-7.38 (m, 2H), 7.37$7.31(\mathrm{~m}, 4 \mathrm{H}), 7.27-7.23(\mathrm{~m}, 3 \mathrm{H}), 7.22-7.19(\mathrm{~m}, 2 \mathrm{H}), 6.10(\mathrm{dd}, J=6.4,2.3 \mathrm{~Hz}, 1 \mathrm{H}), 4.67$ (app dt, $J=6.5,1.9 \mathrm{~Hz}, 1 \mathrm{H}), 4.62(\mathrm{~d}, J=2.9 \mathrm{~Hz}, 1 \mathrm{H}), 4.56-4.51(\mathrm{~m}, 2 \mathrm{H}), 4.36(\mathrm{~d}, J=11.7$ $\mathrm{Hz}, 1 \mathrm{H}), 4.36-4.31(\mathrm{~m}, 1 \mathrm{H}), 4.24(\mathrm{td}, J=10.4,6.9 \mathrm{~Hz}, 1 \mathrm{H}), 4.20(\operatorname{app} \mathrm{dt}, J=4.6,2.3 \mathrm{~Hz}$, $1 \mathrm{H}), 4.10(\mathrm{~d}, J=5.1 \mathrm{~Hz}, 1 \mathrm{H}), 3.72(\operatorname{app~p}, J=6.2 \mathrm{~Hz}, 1 \mathrm{H}), 1.27(\mathrm{~d}, J=6.4 \mathrm{~Hz}, 3 \mathrm{H}), 1.08$ (s, 9H), 0.07 (s, 9H).

${ }^{13} \mathrm{C}$ NMR $\left(125 \mathrm{MHz}, \mathrm{CDCl}_{3}\right): \delta 157.1,141.8,138.2,136.0(2 \times \mathrm{C}), 133.8,133.6,129.9(2 \times \mathrm{C})$, $128.5,127.9,127.8(3 \times \mathrm{C}), 102.0,77.5,77.3,73.6,72.4,71.9,64.8,63.0,27.0,19.4,17.8$, 17.2, 1.2.

FTIR (neat, $\left.\mathrm{cm}^{-1}\right)$ : 2954 (m), $2858(\mathrm{~m}), 1703$ (m), $1328(\mathrm{~m}), 1112(\mathrm{~s}), 1066$ (s), $838(\mathrm{~m}), 702(\mathrm{~s})$. HRMS (ESI+, $m / z):[\mathrm{M}+\mathrm{H}]^{+}$calc'd for $\mathrm{C}_{37} \mathrm{H}_{49} \mathrm{NO}_{6} \mathrm{Si}_{2}, 660.3171$; found 660.3164 . 


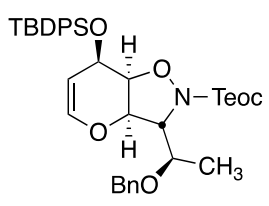

25

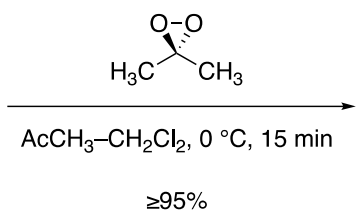

$\geq 95 \%$

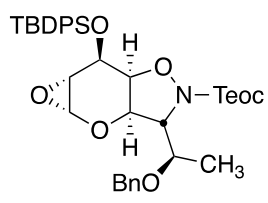

26

\section{Glycal epoxide 26.}

A solution of dimethyldioxirane in acetone was prepared, and its concentration was assayed according to the procedure of Murray and Singh. ${ }^{22}$ A solution of glycal 25 (1.45 g, $2.20 \mu \mathrm{mol}, 1$ equiv) in dichloromethane $(22.0 \mathrm{~mL})$ was cooled to $0{ }^{\circ} \mathrm{C}$, whereupon dimethyldioxirane solution (0.0997 M, $26.4 \mathrm{~mL}, 2.64 \mu \mathrm{mol}, 1.20$ equiv) was added dropwise over $1 \mathrm{~min}$. The reaction mixture was stirred at $0{ }^{\circ} \mathrm{C}$ for $15 \mathrm{~min}$, at which point TLC analysis (20\% ethyl acetate-hexanes, UV+PAA) indicated full consumption of starting material. The mixture was then concentrated under a stream of dry argon, and the residue was dried by azeotropic removal of benzene to afford glycal epoxide 26 as a colorless oil that was suitable for use without further purification (quantitative yield, $\geq 95 \%$ purity by NMR).

$\mathrm{R}_{f}=0.56\left(\mathrm{NH}_{2}\right.$ silica gel, ${ }^{23} 2 \%$ methanol-20\% ethyl acetate-hexanes, UV+CAM).

${ }^{1} \mathrm{H}$ NMR (500 MHz, C6 $\left.\mathrm{D}_{6}\right) \delta$ 7.89-7.83 (m, 2H), 7.77-7.71 (m, 2H), 7.21-7.09 (m, 7H), 7.08-7.00 $(\mathrm{m}, 4 \mathrm{H}), 4.66(\mathrm{dd}, J=2.6,1.0 \mathrm{~Hz}, 1 \mathrm{H}), 4.42(\mathrm{~d}, J=5.1 \mathrm{~Hz}, 1 \mathrm{H}), 4.34-4.21(\mathrm{~m}, 4 \mathrm{H}), 4.21$ $(\mathrm{d}, J=11.8 \mathrm{~Hz}, 1 \mathrm{H}), 4.12-4.08(\mathrm{~m}, 1 \mathrm{H}), 4.05(\mathrm{~d}, J=11.8 \mathrm{~Hz}, 1 \mathrm{H}), 3.56(\operatorname{app} \mathrm{p}, J=6.2 \mathrm{~Hz}$ 1H), 2.97-2.92 (m, 1H), $1.19(\mathrm{~d}, J=0.7 \mathrm{~Hz}, 9 \mathrm{H}), 0.95(\mathrm{~d}, J=6.4 \mathrm{~Hz}, 3 \mathrm{H}), 0.91$ (ddd, $J=$ 9.4, 6.7, 3.9 Hz, 2H), $-0.11(\mathrm{~d}, J=0.7 \mathrm{~Hz}, 9 \mathrm{H})$.

\footnotetext{
${ }^{22}$ Murray, R. W.; Singh, M. Org. Synth. 1997, 74, 91.

${ }^{23}$ Note: The acid-sensitive product is unstable toward chromatography using standard silica gel.
} 
${ }^{13} \mathrm{C}$ NMR $\left(125 \mathrm{MHz}, \mathrm{C}_{6} \mathrm{D}_{6}\right) \delta 157.95,138.78,136.31,136.13,133.68,133.47,130.36,130.34$, $128.59,128.35,128.31,128.25,128.20,128.06,127.87,127.75,77.12,74.25,74.12$, $73.79,73.33,71.60,67.08,64.65,51.67,27.12,19.63,17.74,16.79,-1.45$.

FTIR (neat, $\left.\mathrm{cm}^{-1}\right)$ : $2953(\mathrm{~m}), 2858(\mathrm{~m}), 1703(\mathrm{~m}), 1249(\mathrm{~m}), 1112(\mathrm{~s}), 837(\mathrm{~s}), 701(\mathrm{~s})$. HRMS (ESI+, $m / z)$ : $[\mathrm{M}+\mathrm{H}]^{+}$calc'd for $\mathrm{C}_{37} \mathrm{H}_{49} \mathrm{NO}_{7} \mathrm{Si}_{2}, 676.3120$; found 676.3118 . 

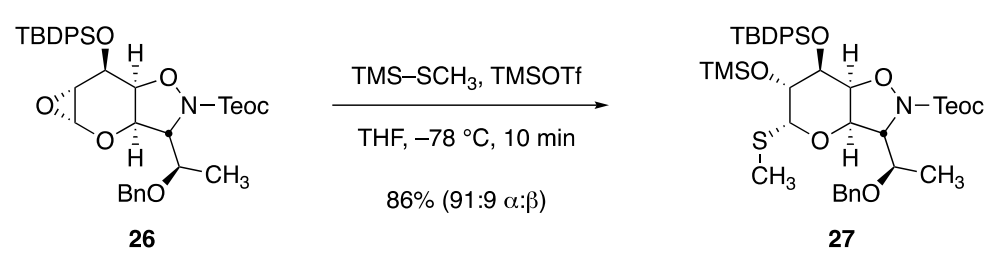

\section{Thioglycoside 27.}

A $10-\mathrm{mL}$ round-bottomed flask was charged with a magnetic stir bar and glycal epoxide $\mathbf{2 6}$ (103 mg, $152 \mu \mathrm{mol}, 1$ equiv). This starting material was dried by azeotropic removal of benzene before it was dissolved in tetrahydrofuran $(760 \mu \mathrm{L})$. The solution was chilled to $-78{ }^{\circ} \mathrm{C}$ before trimethyl(methylthio)silane $(65.7 \mu \mathrm{L}, 456 \mu$ mol, 3.00 equiv) was added. Trimethylsilyl trifluoromethanesulfonate $\left(5.49 \mu \mathrm{L}, 30.4 \mu \mathrm{mol}, 0.200\right.$ equiv) was then added dropwise at $-78^{\circ} \mathrm{C}$, and stirring was maintained at that temperature. Progress was monitored by $\mathrm{TLC}\left(\mathrm{NH}_{2}\right.$ silica gel, $2 \%$ methanol-20\% ethyl acetate-hexanes, UV+CAM), and after $10 \mathrm{~min}$, the reaction was judged to be complete. The mixture was neutralized with the addition of $5 \% \mathrm{v} / \mathrm{v}$ triethylaminedichloromethane (500 $\mu \mathrm{L})$, and the quenched reaction mixture was concentrated in vacuo. Crude ${ }^{1} \mathrm{H}-\mathrm{NMR}$ analysis revealed a 91:9 mixture of anomers; this mixture was subjected to flash-column chromatography (12 g silica gel, eluting with hexanes initially, grading to $20 \%$ ethyl acetatehexanes) to provide the product as a colorless oil (105 $\mathrm{mg}, 86 \%)$.

$\mathrm{R}_{f}=0.40$ (20\% ethyl acetate-hexanes, UV+PMA).

${ }^{1} \mathrm{H}$ NMR (500 MHz, $\left.\mathrm{CDCl}_{3}\right) \delta$ 7.88-7.86 (m, 2H), 7.82-7.80 (m, 2H), 7.44-7.34 (m, 6H), 7.27$7.22(\mathrm{~m}, 3 \mathrm{H}), 7.13-7.11(\mathrm{~m}, 2 \mathrm{H}), 5.08(\mathrm{~d}, J=4.9 \mathrm{~Hz}, 1 \mathrm{H}), 4.52(\mathrm{~d}, J=2.2 \mathrm{~Hz}, 1 \mathrm{H}), 4.42$ (d, $J=11.8 \mathrm{~Hz}, 1 \mathrm{H}), 4.41(\mathrm{dd}, J=9.1,5.1 \mathrm{~Hz}), 4.33(\operatorname{app} \mathrm{t}, J=8.5 \mathrm{~Hz}, 2 \mathrm{H}), 4.19(\mathrm{dd}, J=$ 9.5, $3.8 \mathrm{~Hz}, 1 \mathrm{H}), 4.17(\mathrm{~d}, J=11.6 \mathrm{~Hz}, 1 \mathrm{H}), 4.02(\mathrm{~d}, J=6.6 \mathrm{~Hz}, 1 \mathrm{H}), 3.70(\mathrm{dd}, J=3.8,2.3$ 
$\mathrm{Hz}, 1 \mathrm{H}), 3.31(\operatorname{app} \mathrm{p}, J=6.2 \mathrm{~Hz}, 1 \mathrm{H}), 1.97(\mathrm{~s}, 3 \mathrm{H}), 1.21(\mathrm{~d}, J=6.2 \mathrm{~Hz}, 3 \mathrm{H}), 1.11(\mathrm{~s}, 9 \mathrm{H})$, $0.20(\mathrm{~s}, 9 \mathrm{H}), 0.11(\mathrm{~s}, 9 \mathrm{H})$.

${ }^{13} \mathrm{C} \mathrm{NMR}\left(126 \mathrm{MHz}, \mathrm{CDCl}_{3}\right) \delta 158.2,138.0,136.2,136.1,134.5,133.3,129.8,129.6,128.4,127.7$ $(2 \times C), 127.6,127.5,87.3,79.6,73.3,73.1,71.6(2 \times C), 70.2,69.8,64.7,27.1,19.4,17.8$, $17.2,12.7,0.4,-1.3$

IR (neat, $\mathrm{cm}^{-1}$ ): 1703 (m), 1325 (m), 1105 (m), 1063 (m), 837 (s), 731 (s), 699 (s).

HRMS (ESI+, $m / z)$ : $[\mathrm{M}+\mathrm{Na}]^{+}$calc'd for $\mathrm{C}_{41} \mathrm{H}_{61} \mathrm{NO}_{7} \mathrm{SSi}_{3}, 818.3369$; found 818.3356. 


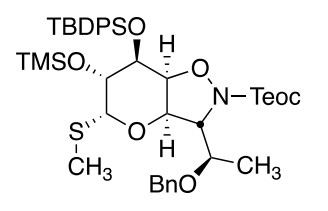

27

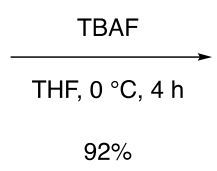

$92 \%$

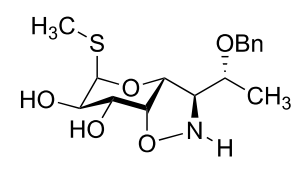

S7

\section{Isoxazolidine diol S7.}

To a stirred solution of thioglycoside 27 (104 mg, $131 \mu \mathrm{mol}$, 1equiv) in tetrahydrofuran $(1.87 \mathrm{~mL})$ was added tetrabutylammonium fluoride solution $(1.0 \mathrm{M}$ in tetrahydrofuran, $650 \mu \mathrm{L}$, $650 \mu \mathrm{mol}, 5.0$ equiv) at $0{ }^{\circ} \mathrm{C}$. Progress was monitored by flow-injection analysis mass spectrometry, which showed rapid $(<20 \mathrm{~min})$ cleavage of the trimethylsilyl and (trimethylsilyl)ethoxycarbonyl groups; the tert-butyldiphenylsilyl group was removed more slowly. After $4 \mathrm{~h}$ at $0{ }^{\circ} \mathrm{C}$, the reaction was judged to be complete, and the mixture was quenched with the addition of saturated aqueous sodium bicarbonate solution $(10 \mathrm{~mL})$. The resulting mixture was extracted with ethyl acetate $(3 \times 10 \mathrm{~mL})$, and the combined extracts were washed with saturated aqueous sodium chloride solution $(10 \mathrm{~mL})$. Before it was discarded, the sodium chloride solution was extracted with fresh portions of ethyl acetate $(2 \times 5 \mathrm{~mL})$, and the combined organic extracts were dried over sodium sulfate. The dried product solution was filtered, and the filtrate was concentrated to give a colorless oil. The crude isoxazolidine was purified by flash-column chromatography (10 g silica gel, eluting initially with $0.2 \%$ ammonium hydroxide- $2 \%$ methanoldichloromethane, grading to $0.3 \%$ ammonium hydroxide- $3 \%$ methanol-dichloromethane in one step) to provide $\mathbf{S 7}$ as a white solid (40.9 $\mathrm{mg}, 92 \%)$.

Owing to nitrogen inversion that occurred on the NMR time scale, the free-base form of this isoxazolidine featured ${ }^{1} \mathrm{H}-\mathrm{NMR}$ peak broadening, as indicated below. For characterization purposes, a portion of this free-base (ca. $12 \mathrm{mg}$ ) was purified by HPLC-MS on a Waters SunFire prep $\mathrm{C}_{18}$ column $(5 \mu \mathrm{m}, 250 \times 19 \mathrm{~mm}$; eluting with $0.1 \%$ trifluoroacetic acid-10\% acetonitrile- 
water initially, grading to $0.1 \%$ trifluoroacetic acid-80\% acetonitrile-water over 30 min, with a flow rate of $15 \mathrm{~mL} / \mathrm{min}$; monitored by UV absorbance at $254 \mathrm{~nm}$ and by ESI+ selected ion monitoring $[\mathrm{m} / \mathrm{z}=342] ; \mathrm{R}_{t}=14.8 \mathrm{~min}$ ) to provide the product as the corresponding hydrotrifluoroacetate salt, which featured sharper NMR peaks.

$\mathrm{R}_{f}=0.31$ (free base, $1 \%$ ammonium hydroxide-10\% methanol-dichloromethane, UV+PAA).

${ }^{1} \mathrm{H}$ NMR (free base, $\left.600 \mathrm{MHz}, \mathrm{CDCl}_{3}\right) \delta$ 7.37-7.35 (m, 2H), 7.32-7.28 (m, 2H), $5.24(\mathrm{~d}, J=4.9$ $\mathrm{Hz}, 1 \mathrm{H}), 4.87(\mathrm{br}, 1 \mathrm{H}), 4.66(\mathrm{~d}, J=11.7 \mathrm{~Hz}, 1 \mathrm{H}), 4.35(\mathrm{~d}, J=11.6 \mathrm{~Hz}, 1 \mathrm{H}), 4.11(\mathrm{br}, 1 \mathrm{H})$, 3.95 (br, 1H), 3.91 (dd, $J=4.4,2.8 \mathrm{~Hz}, 1 \mathrm{H}), 3.55$ (br, 1H), 3.36 (br, 1H), 3.17 (br, 1H), $3.03(\mathrm{br}, 1 \mathrm{H}), 2.15(\mathrm{~s}, 3 \mathrm{H}), 1.32(\mathrm{~d}, J=6.2 \mathrm{~Hz}, 3 \mathrm{H})$.

${ }^{1} \mathrm{H}$ NMR (hydrotrifluoroacetate salt, $\left.500 \mathrm{MHz}, \mathrm{CD}_{3} \mathrm{OD}\right) \delta 7.38-7.34(\mathrm{~m}, 4 \mathrm{H}), 7.31-7.29$ (m, 1H), $5.26(\mathrm{~d}, J=5.0 \mathrm{~Hz}, 1 \mathrm{H}), 5.06(\mathrm{~d}, J=2.2 \mathrm{~Hz}, 1 \mathrm{H}), 4.69(\mathrm{~d}, J=11.1 \mathrm{~Hz}, 1 \mathrm{H}), 4.56(\mathrm{dd}, J=$ 4.1, 2.3 Hz, 1H), $4.49(\mathrm{~d}, J=11.1 \mathrm{~Hz}, 1 \mathrm{H}), 4.09(\mathrm{dd}, J=10.0,5.0 \mathrm{~Hz}, 1 \mathrm{H}), 3.99-3.97$ (m, 2H), $3.93(\mathrm{dd}, J=9.9,4.0 \mathrm{~Hz}, 1 \mathrm{H}), 2.12(\mathrm{~s}, 3 \mathrm{H}), 1.39(\mathrm{~d}, J=5.8 \mathrm{~Hz}, 3 \mathrm{H})$.

${ }^{13} \mathrm{C}$ NMR (hydrotrifluoroacetate salt, $\left.126 \mathrm{MHz}, \mathrm{CD}_{3} \mathrm{OD}\right) \delta 139.1,129.5,128.9(2 \times \mathrm{C}), 88.8,85.6$, $75.0,73.1,72.8,72.1,69.0,68.7,16.6,13.1$.

FTIR (neat, cm ${ }^{-1}$ ): 3317 (br, w), 1668 (s), 1433 (w), 1197 (s), 1142 (s), 1093 (s) 699 (m). HRMS (ESI+, $m / z)$ : $[\mathrm{M}+\mathrm{H}]^{+}$calc'd for $\mathrm{C}_{16} \mathrm{H}_{23} \mathrm{NO}_{5} \mathrm{~S}, 342.1370$; found 342.1365. 


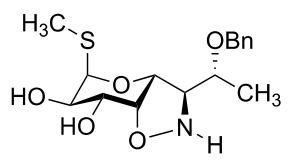

S7

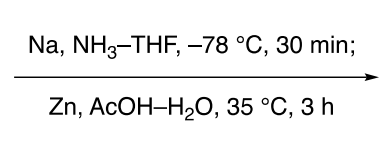

$89 \%$

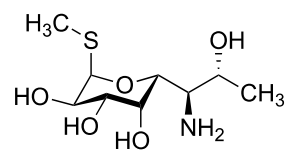

MTL (1)

\section{Completion of the synthesis of methylthiolincosamine (1).}

A flame-dried 2-5-mL glass microwave reaction vial was fitted with a magnetic stir bar and was sealed with a rubber septum. The septum was pierced with a 20 -gauge needle to supply dry argon gas, and a second needle was used to vent the apparatus; under a steady stream of argon to exclude air and moisture, the empty apparatus was chilled to $-78{ }^{\circ} \mathrm{C}$. The chilled flask was then slowly charged with anhydrous ammonia gas (supplied via a 22-gauge needle). After approximately $2 \mathrm{~mL}$ of liquid ammonia was condensed in this fashion, the needle supplying ammonia gas was removed, and a small piece of sodium metal (approximately $1 \mathrm{~mm}^{3}$ ) was added. The mixture attained a deep blue color, and was stirred at $-78^{\circ} \mathrm{C}$ for $5 \mathrm{~min}$. After this time, a solution of isoxazolidine $\mathbf{S 7}(40.0 \mathrm{mg}, 117 \mu \mathrm{mol}, 1$ equiv) in tetrahydrofuran $(500 \mu \mathrm{L})$ was introduced dropwise via syringe. During this addition, the blue coloration of the reaction mixture disappeared, signaling that the initial portion of sodium metal was fully consumed; additional 1$\mathrm{mm}^{3}$ pieces of sodium were added until a deep-blue color persisted. The mixture was then stirred at $-78{ }^{\circ} \mathrm{C}$ for $30 \mathrm{~min}$, until LCMS analysis indicated that $O$-debenzylation was complete $(\mathrm{N}-\mathrm{O}$ bond cleavage stalls in the course of this reaction, leaving a roughly 50:50 mixture of fully reduced product and $O$-debenzylated isoxazolidine intermediate even after prolonged exposure to dissolving-metal conditions). Solid ammonium chloride was added portionwise in order to quench excess reductant, until a colorless mixture was obtained; the apparatus was then allowed to warm to $23{ }^{\circ} \mathrm{C}$ in order to allow the ammonia co-solvent to evaporate. The mixture was then dried in vacuo to provide a white solid residue. 
This residue was re-dissolved in $50 \% \mathrm{v} / \mathrm{v}$ acetic acid-water $(1.0 \mathrm{~mL})$, zinc powder $(30.6$ mg, $469 \mu$ mol, 4.00 equiv) was added, and the mixture was heated to $35^{\circ} \mathrm{C}$ with stirring, in order to quantitate $\mathrm{N}-\mathrm{O}$ bond cleavage of intermediate isoxazolidine compound. After $3 \mathrm{~h}$, LCMS analysis revealed that no isoxazolidine remained, and the mixture was filtered through a pad of Celite in order to remove any residual zinc metal. The filtrate was concentrated, and residual acetic acid and water were removed by repeated azeotropic concentration from $50 \%$ v/v methanoltoluene. The dried residue, containing the aminotetraol as its hydroacetate salt, along with zinc acetate and ammonium acetate, was dissolved in methanol $(5.0 \mathrm{~mL})$, and Amberlyst A26 ionexchange resin (hydroxide form, $1.0 \mathrm{~g}$ ) was added. The mixture was stirred at $23{ }^{\circ} \mathrm{C}$ for $1 \mathrm{~h}$ before the ion-exchange beads were removed by filtration. The filtrate was concentrated to provide crude product in its free-base form. This residue was purified by flash-column chromatography (4.0 g silica gel, eluting with $1 \%$ ammonium hydroxide-10\% methanol-dichloromethane initially, grading to $10 \%$ ammonium hydroxide-40\% methanol-dichloromethane) to provide methylthiolincosamine (1) as a brilliant white solid (26.4 mg, 89\%).

$\mathrm{R}_{f}=0.42$ (10\% ammonium hydroxide-40\% methanol-dichloromethane, PAA).

${ }^{1} \mathrm{H}$ NMR $\left(500 \mathrm{MHz}, \mathrm{D}_{2} \mathrm{O}\right) \delta 5.17(\mathrm{~d}, J=5.8 \mathrm{~Hz}, 1 \mathrm{H}), 3.97-3.93(\mathrm{~m}, 3 \mathrm{H}), 3.82(\mathrm{~d}, J=9.6 \mathrm{~Hz}, 1 \mathrm{H})$, $3.50(\mathrm{dd}, J=10.4,3.3 \mathrm{~Hz}, 1 \mathrm{H}), 3.01(\mathrm{dd}, J=9.6,3.6 \mathrm{~Hz}, 1 \mathrm{H}), 1.97(\mathrm{~s}, 3 \mathrm{H}), 0.99$ (d, $J=6.4$ $\mathrm{Hz}, 3 \mathrm{H})$.

${ }^{13} \mathrm{C}$ NMR $\left(126 \mathrm{MHz}, \mathrm{D}_{2} \mathrm{O}\right) \delta 88.0,71.3,70.4,68.3,67.7,67.1,53.6,14.2,12.9$.

FTIR (neat, $\mathrm{cm}^{-1}$ ): 3280 (br), 2904 (m), 1385 (m), 1076 (m), 1041 (s), 866 (m). HRMS (ESI+, $m / z):[\mathrm{M}+\mathrm{H}]^{+}$calc'd for $\mathrm{C}_{9} \mathrm{H}_{19} \mathrm{NO}_{5} \mathrm{~S}, 254.1057$; found 254.1055. 

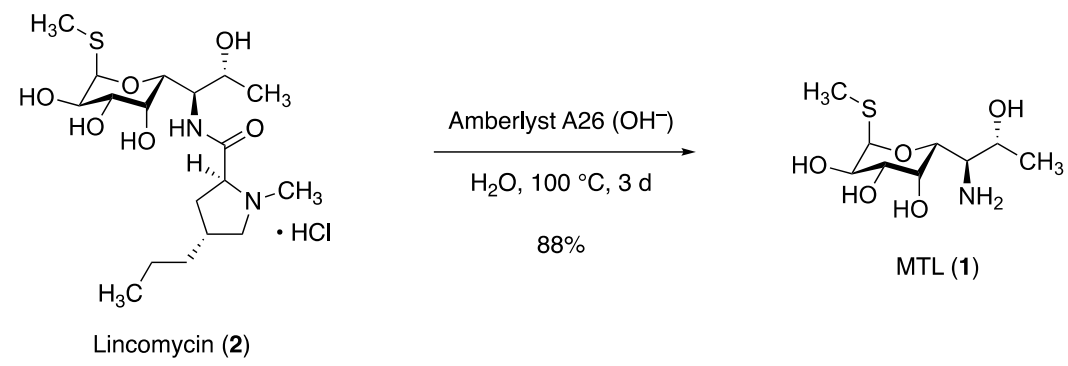

MTL (1)

\section{Semisynthetic preparation of methylthiolincosamine (1).}

Based on the original report of Schroeder, Bannister, and Hoeksema, ${ }^{24}$ an improved procedure for the preparation of methylthiolincosamine (1) from lincomycin (2) avoiding the use of the hazardous reagent hydrazine was developed. In a 250-mL round-bottomed flask, lincomycin hydrochloride (2 $\cdot \mathrm{HCl}, 1.58 \mathrm{~g}, 3.57 \mathrm{mmol}, 1$ equiv), Amberlyst A26 ion-exchange resin (hydroxide form, $15.8 \mathrm{~g}$ ), and water $(71.3 \mathrm{~mL})$ were combined. The flask was fitted with a reflux condenser, and the mixture was heated to reflux for $3 \mathrm{~d}$, at which point LCMS analysis indicated that hydrolysis was complete. The mixture was allowed to cool to ambient temperature before the ion-exchange beads were removed by filtration. The filtrate was concentrated directly to afford pure methylthiolincosamine (MTL, 1) free base as a brilliant white solid (795 mg, 88\%).

The TLC $\mathrm{R}_{f},{ }^{1} \mathrm{H}-\mathrm{NMR},{ }^{13} \mathrm{C}-\mathrm{NMR}$, and HRMS data were identical to those of the synthetic sample prepared by the route described above.

\footnotetext{
${ }^{24}$ Schroeder, W.; Bannister, B.; Hoeksema, H. J. Am. Chem. Soc. 1967, 89, 2448-2453.
} 


\section{Synthesis of $C$-Glycosides 29, 30, and 31}

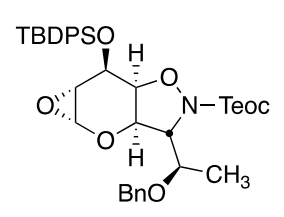

26

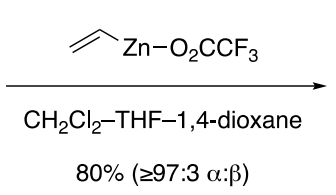

$80 \%(\geq 97: 3 \alpha: \beta)$

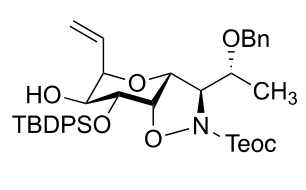

28

\section{Vinyl glycoside 28.}

An oven-dried 100-mL round-bottom flask was charged with a stir bar and divinylzinc solution (0.15 M solution in tetrahydrofuran-dioxane, $21.7 \mathrm{~mL}, 3.3 \mathrm{mmol}, 2.3$ equiv; prepared according to the method of Brubaker and Myers; $;{ }^{25}$ titrated according to the method of Krasovskiy and $\mathrm{Knochel}^{26}$ ). This solution was chilled to $0{ }^{\circ} \mathrm{C}$, and trifluoroacetic acid $(250 \mu \mathrm{L}, 3.3 \mathrm{mmol}, 2.3$ equiv) was then added dropwise. The resulting solution was stirred for $30 \mathrm{~min}$ at $0{ }^{\circ} \mathrm{C}$ prior to use.

In a separate 100-mL round-bottom flask, epoxide 26 (954 mg, $1.41 \mathrm{mmol}, 1$ equiv) was dried by azeotropic removal of benzene. The dried epoxide was dissolved in anhydrous dichloromethane $(14.1 \mathrm{~mL})$, and the resulting solution was chilled to $0{ }^{\circ} \mathrm{C}$. This epoxide solution was then transferred by cannula to the flask containing freshly prepared vinylzinc trifluoroacetate, also at $0{ }^{\circ} \mathrm{C}$. The resulting solution was stirred at $0{ }^{\circ} \mathrm{C}$ for $4 \mathrm{~h}$, at which point TLC analysis $\left(\mathrm{NH}_{2}\right.$ silica gel, $20 \%$ ethyl acetate-hexanes $+2 \%$ methanol, UV+CAM) indicated full consumption of epoxide starting material. The reaction was quenched with the addition of $35 \mathrm{~mL}$ of saturated aqueous ammonium chloride solution, and the resulting biphasic mixture was stirred for $10 \mathrm{~min}$. The layers were then separated, and the aqueous phase was extracted with dichloromethane $(3 \times$ $20 \mathrm{~mL}$ ). The combined organic extracts were washed with saturated aqueous sodium chloride

\footnotetext{
${ }^{25}$ Brubaker, J. D.; Myers, A. G. Org. Lett. 2007, 9, 3523-3525.

${ }^{26}$ Krasovskiy, A.; Knochel, P. Synthesis 2006, 890-891.
} 
solution, and the washed organic product solution was dried over sodium sulfate. The dried solution was filtered, and the filtrate was concentrated to afford crude product as a faint yellow oil. The product was purified by flash-column chromatography (40 g silica, eluting with $5 \%$ ethyl acetate-hexanes initially, grading to $20 \%$ ethyl acetate-hexanes) to provide $\mathbf{2 8}$ as a colorless oil (846 mg, $1.20 \mathrm{mmol}, 85 \%)$.

$\mathrm{R}_{f}=0.47$ (20\% ethyl acetate-hexanes, $\mathrm{UV}+\mathrm{KMnO}_{4}$ ).

${ }^{1} \mathrm{H}$ NMR $\left(600 \mathrm{MHz}, \mathrm{C}_{6} \mathrm{D}_{6}\right) \delta$ 7.96-7.94 (m, 2H), 7.83-7.79 (m, 2H), 7.22-7.19 (m, 2H), 7.18-7.16 (m, 1H), 7.15-7.11 (m, 4H), 7.07-7.00 (m, 4H). $5.74(\mathrm{ddd}, J=17.6,11.0,4.1 \mathrm{~Hz}, 1 \mathrm{H})$, 5.20 (app dt, $J=17.6,2.1 \mathrm{~Hz}, 1 \mathrm{H}), 4.95$ (app dt, $J=11.1,2.1 \mathrm{~Hz}, 1 \mathrm{H}), 4.57$ (app dt, $J=$ 9.7, $5.0 \mathrm{~Hz}, 1 \mathrm{H}), 4.53(\mathrm{~d}, J=2.4 \mathrm{~Hz}, 1 \mathrm{H}), 4.50$ (app ddt, $J=6.1,4.3,2.2 \mathrm{~Hz}, 1 \mathrm{H}), 4.40$ (d, $J=5.4 \mathrm{~Hz}, 1 \mathrm{H}), 4.33($ app td, $J=10.3,6.5 \mathrm{~Hz}, 1 \mathrm{H}), 4.30-4.25(\mathrm{~m}, 2 \mathrm{H}), 4.23($ app t,$J=3.0$ $\mathrm{Hz}, 1 \mathrm{H}), 4.09(\mathrm{~d}, J=11.8 \mathrm{~Hz}, 1 \mathrm{H}), 4.01(\mathrm{dd}, J=9.7,3.6 \mathrm{~Hz}, 1 \mathrm{H}), 3.60($ app qn, $J=6.2 \mathrm{~Hz}$, $1 \mathrm{H}), 1.71(\mathrm{~d}, J=4.2 \mathrm{~Hz}, 1 \mathrm{H}), 1.18(\mathrm{~s}, 9 \mathrm{H}), 1.07(\mathrm{~d}, J=6.3 \mathrm{~Hz}, 3 \mathrm{H}), 0.97-0.91(\mathrm{~m}, 2 \mathrm{H}),-$ 0.09 (s, 9H).

${ }^{13} \mathrm{C}$ NMR (126 MHz, $\left.\mathrm{CDCl}_{3}\right) \delta 157.9,138.1,136.2,135.8,133.5,133.3,130.8,130.1,128.5$, $128.0,127.9,127.8,127.8,119.2,80.2,76.3,74.6,73.2,72.5,71.7,71.1,68.7,64.8,27.1$, $19.5,17.7,17.3,-1.2$. Overlap of a single pair of phenyl carbon resonances accounts for the observation of only 11 unique phenyl-derived signals.

FTIR (neat, $\mathrm{cm}^{-1}$ ): 3473 (br), 2953 (m), 2931 (m), 2895 (m), 2858 (m), 1702 (m), 1427 (m), 1250 (m), $1112(\mathrm{~s}), 1082(\mathrm{~s}), 838(\mathrm{~m}), 702(\mathrm{~s})$.

HRMS (ESI+, $m / z):[\mathrm{M}+\mathrm{H}]^{+}$calc'd for $\mathrm{C}_{39} \mathrm{H}_{53} \mathrm{NO}_{7} \mathrm{Si}_{2}, 704.3433$; found 704.3418 


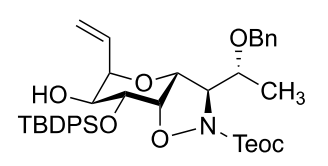

28

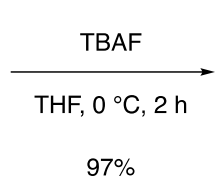

$97 \%$

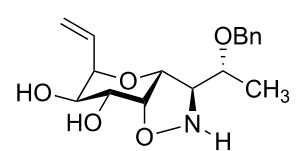

S8

\section{Isoxazolidine diol S8.}

In a 10-mL round-bottomed flask, isoxazolidine 28 (150 mg, $213 \mu \mathrm{mol}, 1$ equiv) was dissolved in tetrahydrofuran $(2.13 \mathrm{~mL})$. The resulting solution was chilled to $0{ }^{\circ} \mathrm{C}$ before it was treated with tetra- $n$-butylammonium fluoride solution $(1.0 \mathrm{M}$ in tetrahydrofuran, $640 \mu \mathrm{L}, 3.0$ equiv). While cleavage of the 2-(trimethylsilyl)ethyl carbamoyl protecting group is rapid, the tertbutyldiphenylsilyl ether group is less labile. After $2 \mathrm{~h}$ of stirring at $0{ }^{\circ} \mathrm{C}, \mathrm{LCMS}$ analysis showed that global desilylation was complete and the reaction mixture was treated with saturated aqueous sodium bicarbonate solution $(2 \mathrm{~mL})$ and saturated aqueous sodium chloride solution $(5 \mathrm{~mL})$. This mixture was extracted with dichloromethane $(3 \times 10 \mathrm{~mL})$, and the combined extracts were dried directly over sodium sulfate. The dried solution was then filtered, the filtrate was concentrated, and the crude residue was purified by flash-column chromatography (12 g silica gel, eluting with dichloromethane initially, grading to $10 \%$ methanol-dichloromethane) to furnish isoxazolidine diol product as a viscous, colorless oil (66.4 mg, 97\%).

In its free-base form, this product displayed substantial ${ }^{1} \mathrm{H}$ - and ${ }^{13} \mathrm{C}-\mathrm{NMR}$ peak broadening, likely owing to a nitrogen inversion process occurring on the NMR timescale. Thus, for NMR characterization purposes, the product was converted to its hydrochloride salt form by treating an ice-cold solution of free base $(61 \mathrm{mg}, 190 \mu \mathrm{mol}, 1$ equiv) in methanol $(5.0 \mathrm{~mL})$ with hydrogen chloride solution (4.0 M in 1,4-dioxane, $190 \mu \mathrm{L}, 760 \mu \mathrm{mol}, 4.0$ equiv). The mixture was then concentrated in vacuo to provide the hydrochloride salt $\mathbf{S 8} \cdot \mathrm{HCl}$ as a white solid. 
$\mathrm{R}_{f}=0.40$ (free base, $10 \%$ methanol-dichloromethane, $\mathrm{I}_{2}$ ).

${ }^{1} \mathrm{H}$ NMR (hydrochloride salt, $\left.500 \mathrm{MHz}, \mathrm{CD}_{3} \mathrm{OD}\right) \delta$ 7.39-7.33 (m, 4H), 7.30-7.27 (m, 1H), 6.09 (ddd, $J=17.4,10.8,5.2 \mathrm{~Hz}, 1 \mathrm{H}$ ), 5.43 (app dt, $J=17.4,1.9 \mathrm{~Hz}, 1 \mathrm{H}$ ), 5.40 (app dt, $J=10.1$, $1.8 \mathrm{~Hz}, 1 \mathrm{H}), 5.01(\mathrm{dd}, J=3.4,2.1 \mathrm{~Hz}, 1 \mathrm{H}), 4.71-4.70(\mathrm{~m}, 1 \mathrm{H}), 4.67(\mathrm{~d}, J=11.1 \mathrm{~Hz}, 1 \mathrm{H})$, 4.57-4.55 (m, 1H), $4.53(\mathrm{~d}, J=11.1 \mathrm{~Hz}, 1 \mathrm{H}), 4.14($ app t, $J=2.5 \mathrm{~Hz}, 1 \mathrm{H}), 4.09(\mathrm{qd}, J=$ 6.2, 3.0 Hz, 1H), 3.96-3.95 (m, 2H), $1.40(\mathrm{~d}, J=6.3 \mathrm{~Hz}, 3 \mathrm{H})$.

${ }^{13} \mathrm{C}$ NMR (hydrochloride salt, $\left.126 \mathrm{MHz}, \mathrm{CD}_{3} \mathrm{OD}\right) \delta$ 139.1, 132.7, 129.4, $128.8(2 \times \mathrm{C}), 119.8$, $84.1,76.8,75.3,72.5,72.0,71.4,69.2,68.5,16.1$.

FTIR (hydrochloride salt, neat, $\mathrm{cm}^{-1}$ ): 3390 (br), 2895 (m), 1454 (m), 1087 (s), 698 (s). HRMS (ESI+, m/z): [M+H] $]^{+}$calc'd for $\mathrm{C}_{17} \mathrm{H}_{23} \mathrm{NO}_{5}, 322.1649$; found 322.1658 . 


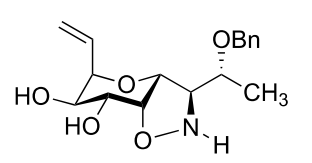

S8

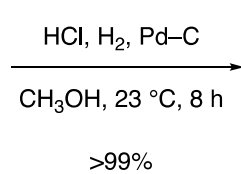

$>99 \%$

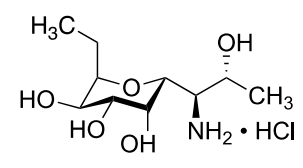

29

\section{Aminotetraol 29.}

In a 10-mL round-bottomed flask, isoxazolidine $\mathbf{S 8}(67.6 \mathrm{mg}, 0.189 \mathrm{mmol}, 1$ equiv) was dissolved in methanol $(1.00 \mathrm{~mL})$, and the solution was treated with hydrogen chloride solution (4.0 $\mathrm{M}$ in 1,4-dioxane, $190 \mu \mathrm{L}, 4.0$ equiv). The mixture was then concentrated to dryness to provide the hydrochloride salt of the starting material; this salt was dissolved in methanol (1.89 $\mathrm{mL})$, and the solution was treated with palladium on carbon $(10 \% \mathrm{w} / \mathrm{w}, 20 \mathrm{mg})$. The headspace of the flask was replaced with hydrogen gas, and the black suspension was stirred at $23{ }^{\circ} \mathrm{C}$ for $8 \mathrm{~h}$, whereupon LCMS analysis revealed that olefin saturation, isoxazolidine hydrogenation, and debenzylation were all complete. The mixture was filtered through a pad of Celite to remove the catalyst, and the filter cake was washed with fresh methanol $(3 \times 1 \mathrm{~mL})$. The filtrate was concentrated to afford 29 - $\mathrm{HCl}$ as a white foaming solid (54.3 $\mathrm{mg}, 106 \%)$.

${ }^{1} \mathrm{H}$ NMR $\left(600 \mathrm{MHz}, \mathrm{CD}_{3} \mathrm{OD}\right) \delta 4.20(\operatorname{app~t}, J=2.9 \mathrm{~Hz}, 1 \mathrm{H}), 4.13(\operatorname{app} \mathrm{p}, J=6.2 \mathrm{~Hz}, 1 \mathrm{H}), 3.94-$ $3.91(\mathrm{~m}, 2 \mathrm{H}), 3.87(\mathrm{td}, J=7.0,4.6 \mathrm{~Hz}, 1 \mathrm{H}), 3.77(\mathrm{dd}, J=8.2,3.1 \mathrm{~Hz}, 1 \mathrm{H}), 3.63(\operatorname{app~t}, J=$ $6.4 \mathrm{~Hz}, 1 \mathrm{H}), 1.64(\operatorname{app~p}, J=7.3 \mathrm{~Hz}, 2 \mathrm{H}), 1.29(\mathrm{~d}, J=6.4 \mathrm{~Hz}, 3 \mathrm{H}), 0.96(\mathrm{t}, J=7.3 \mathrm{~Hz}, 3 \mathrm{H})$. ${ }^{13} \mathrm{C}$ NMR $\left(126 \mathrm{MHz}, \mathrm{CD}_{3} \mathrm{OD}\right) \delta$ 77.2, 71.5, 69.9, 69.7, 68.7, 65.5, 58.5, 19.7, 18.7, 10.9.

FTIR (neat, cm ${ }^{-1}$ ): 3333 (br), 2968 (m), 2936 (m), 1503 (m), 1070 (s).

HRMS (ESI+, $m / z):[\mathrm{M}+\mathrm{H}]^{+}$calc'd for $\mathrm{C}_{10} \mathrm{H}_{21} \mathrm{NO}_{5}, 236.1492$; found 236.1488. 


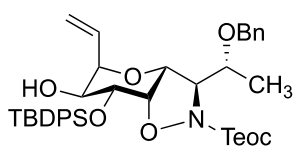

28

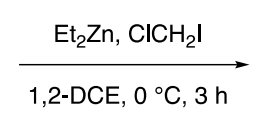

$89 \%$

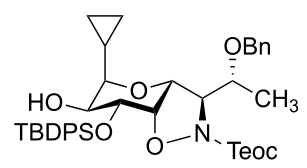

S9

\section{Cyclopropyl glycoside S9.}

Cyclopropanation was performed using the method described by Denmark and Edwards. ${ }^{27}$ In a 2-5-mL glass microwave vial fitted with a magnetic stir bar, a solution of diethylzinc (43.9 $\mu \mathrm{L}, \quad 0.426 \mathrm{mmol}, 3.00$ equiv) in 1,2-dichloroethane $(800 \mu \mathrm{L})$ was chilled to $0{ }^{\circ} \mathrm{C}$. Chloroiodomethane $(61.9 \mu \mathrm{L}, 0.852 \mathrm{mmol}, 6.00$ equiv) was then added dropwise to this solution, and the mixture was stirred at $0{ }^{\circ} \mathrm{C}$ for $5 \mathrm{~min}$ before a solution of olefin $\mathbf{2 8}(100 \mathrm{mg}, 0.142 \mathrm{mmol}$, 1 equiv) in 1,2-dichloroethane $(100 \mu \mathrm{L})$ was added by cannula. The reaction mixture was stirred at $0{ }^{\circ} \mathrm{C}$ for $3 \mathrm{~h}$, whereupon TLC analysis (30\% ethyl acetate-hexanes, UV+CAM) showed complete consumption of starting material. Excess Simmons-Smith reagent was quenched with the addition of saturated aqueous ammonium chloride solution $(2 \mathrm{~mL})$, and the resulting biphasic mixture was extracted with dichloromethane $(3 \times 10 \mathrm{~mL})$. The combined organic extracts were washed with saturated aqueous sodium chloride solution $(10 \mathrm{~mL})$, dried over sodium sulfate, filtered, and concentrated. The residue thus obtained was purified by flash-column chromatography (12 g silica gel, eluting with $20 \%$ ethyl acetate-hexanes initially, grading to $50 \%$ ethyl acetate-hexanes) to furnish $\mathbf{S 9}$ as a colorless oil (90.9 $\mathrm{mg}, 89 \%)$.

$\mathrm{R}_{f}=0.64$ (30\% ethyl acetate-hexanes, UV+CAM).

\footnotetext{
${ }^{27}$ Denmark, S. E.; Edwards, J. P. J. Org. Chem. 1991, 56, 6974-6981.
} 
${ }^{1} \mathrm{H}$ NMR $\left(600 \mathrm{MHz}, \mathrm{CDCl}_{3}\right) \delta 7.83-7.81(\mathrm{~m}, 2 \mathrm{H}), 7.72-7.71(\mathrm{~m}, 2 \mathrm{H}), 7.44-7.40(\mathrm{~m}, 2 \mathrm{H}), 7.38-$ $7.34(\mathrm{~m}, 4 \mathrm{H}), 7.22-7.21(\mathrm{~m}, 3 \mathrm{H}), 7.16-7.14(\mathrm{~m}, 2 \mathrm{H}), 4.51(\mathrm{~d}, J=11.5 \mathrm{~Hz}, 1 \mathrm{H}), 4.41(\mathrm{~d}, J$ $=2.0 \mathrm{~Hz}, 1 \mathrm{H}), 4.31(\mathrm{~d}, J=11.7 \mathrm{~Hz}, 1 \mathrm{H}), 4.30-4.26(\mathrm{~m}, 2 \mathrm{H}), 4.20($ app dtd, $J=7.6,5.0$, $2.5 \mathrm{~Hz}, 1 \mathrm{H}), 4.02-4.00(\mathrm{~m}, 2 \mathrm{H}), 3.95(\mathrm{~d}, J=5.3 \mathrm{~Hz}, 1 \mathrm{H}), 3.62(\operatorname{app~p}, J=6.2 \mathrm{~Hz}, 1 \mathrm{H})$, $3.03(\mathrm{dd}, J=9.6,5.4 \mathrm{~Hz}, 1 \mathrm{H}), 1.75(\mathrm{~d}, J=4.8 \mathrm{~Hz}, 1 \mathrm{H}), 1.25(\mathrm{~d}, J=6.3 \mathrm{~Hz}, 3 \mathrm{H}), 1.11(\mathrm{~s}$, 9H), $1.09-1.06(\mathrm{~m}, 2 \mathrm{H}), 0.61-0.52(\mathrm{~m}, 2 \mathrm{H}), 0.40(\mathrm{tt}, J=9.7,3.9 \mathrm{~Hz}, 1 \mathrm{H}), 0.25$ (ddt, $J=$ $16.1,9.2,4.6 \mathrm{~Hz}, 2 \mathrm{H}), 0.08(\mathrm{~s}, 9 \mathrm{H})$.

${ }^{13} \mathrm{C}$ NMR $\left(126 \mathrm{MHz}, \mathrm{CDCl}_{3}\right) \delta 157.6,138.2,136.3,135.9,133.7,133.5,130.0,128.5,128.0$, $127.8,81.5,79.9,75.1,73.4,72.2,71.9,71.7,70.2,64.7,27.1,19.6,17.7,17.3,7.4,4.9$, $1.7,-1.2$. Overlapping pairs of phenyl carbon resonances are believed to account for the observation of only 9 unique phenyl-derived signals.

FTIR (neat, $\mathrm{cm}^{-1}$ ): 2953 (m), 2931 (m), 2857 (m), 1698 (m), 1428 (m), 1333 (m), 1250 (m), 1113 (s), $1081(\mathrm{~s}), 839(\mathrm{~m}), 702(\mathrm{~s})$.

HRMS (ESI+, $m / z):[\mathrm{M}+\mathrm{H}]^{+}$calc'd for $\mathrm{C}_{40} \mathrm{H}_{55} \mathrm{NO}_{7} \mathrm{Si}_{2}, 718.3590$; found 718.3569. 


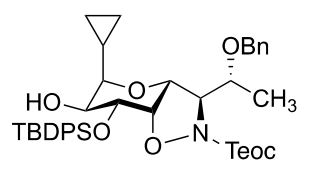

s9

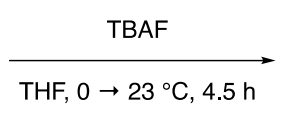

$84 \%$

\section{Isoxazolidine diol S10.}

To an ice-cold solution of $\mathbf{S 9}$ (88 $\mathrm{mg}, 0.12 \mathrm{mmol}, 1$ equiv) in tetrahydrofuran (1.2 $\mathrm{mL}$ ) was added tetra- $n$-butylammonium fluoride solution (1.0 M in tetrahydrofuran, $370 \mu \mathrm{L}, 370 \mu \mathrm{mol}, 3.0$ equiv). The mixture was warmed to $23{ }^{\circ} \mathrm{C}$, and desilylation was monitored by LCMS. While cleavage of the (trimethylsilyl)ethyl carbamate group was rapid $(\sim 30 \mathrm{~min})$, the tertbutyldiphenylsilyl ether linkage underwent more sluggish deprotection. After $4.5 \mathrm{~h}$, the reaction was complete, and the mixture was diluted with saturated aqueous sodium bicarbonate solution. The mixture was then extracted with dichloromethane $(4 \times 10 \mathrm{~mL})$, the combined extracts were dried over sodium sulfate, the dried solution was filtered, and the filtrate was concentrated. This crude residue was purified by flash-column chromatography (4 $\mathrm{g}$ silica gel, eluting with dichloromethane initially, grading to $10 \%$ methanol-dichloromethane) to furnish the product in its free-base form. This material was then converted to its hydrochloride salt by dissolving it in methanol $(3 \mathrm{~mL})$, treating the resulting solution with hydrogen chloride solution $(4.0 \mathrm{M}$ in 1,4 dioxane, $120 \mu \mathrm{L}, 0.49 \mathrm{mmol}, 4.0$ equiv), and concentrating the acidified solution to dryness. This gave the product $(\mathbf{S 1 0} \cdot \mathrm{HCl}, 39 \mathrm{mg}, 84 \%)$ as a light sand-colored solid.

$\mathrm{R}_{f}=0.37$ (free base, $10 \%$ methanol-dichloromethane, $\mathrm{I}_{2}$ ).

${ }^{1} \mathrm{H}$ NMR (hydrochloride salt, $\left.600 \mathrm{MHz}, \mathrm{CDCl}_{3}\right) \delta 7.40(\mathrm{~d}, J=7.0 \mathrm{~Hz}, 2 \mathrm{H}), 7.35(\mathrm{t}, J=7.5 \mathrm{~Hz}$, 2H), $7.28(\mathrm{t}, J=7.3 \mathrm{~Hz}, 1 \mathrm{H}), 5.05(\operatorname{app~t}, J=3.7 \mathrm{~Hz}, 1 \mathrm{H}), 4.74(\operatorname{app} \mathrm{t}, J=4.1 \mathrm{~Hz}, 1 \mathrm{H})$, $4.68(\mathrm{~d}, J=11.1 \mathrm{~Hz}, 1 \mathrm{H}), 4.55(\mathrm{~d}, J=11.2 \mathrm{~Hz}, 1 \mathrm{H}), 4.17(\mathrm{dd}, J=7.7,4.1 \mathrm{~Hz}, 1 \mathrm{H}), 4.11-$ 
$4.07(\mathrm{~m}, 2 \mathrm{H}), 3.88(\mathrm{dd}, J=7.7,3.7 \mathrm{~Hz}, 1 \mathrm{H}), 3.14(\mathrm{dd}, J=9.8,3.7 \mathrm{~Hz}, 1 \mathrm{H}), 1.41(\mathrm{~d}, J=6.0$ $\mathrm{Hz}, 1 \mathrm{H}), 1.15($ app tp, $J=8.6,4.6 \mathrm{~Hz}, 1 \mathrm{H}), 0.65($ app tt, $J=8.3,4.3 \mathrm{~Hz}, 1 \mathrm{H}), 0.58($ app tt, $J=9.1,4.1 \mathrm{~Hz}, 1 \mathrm{H}), 0.36-0.28(\mathrm{~m}, 2 \mathrm{H})$.

${ }^{13} \mathrm{C}$ NMR (hydrochloride salt, $100 \mathrm{MHz}, \mathrm{CDCl}_{3}$ ) $\delta 139.2,129.4,128.8,128.7,82.2,80.2,75.6$, $72.2,71.9,70.4,69.2,68.8,15.9,9.6,4.7,3.0$.

FTIR (hydrochloride salt, neat, $\mathrm{cm}^{-1}$ ): 3347 (br), 2932 (w), 1454 (w), 1339 (w), 1127 (m), 1085 (s), $1026(\mathrm{~m}), 677(\mathrm{~m})$.

HRMS (ESI+, $m / z):[\mathrm{M}+\mathrm{H}]^{+}$calc'd for $\mathrm{C}_{18} \mathrm{H}_{25} \mathrm{NO}_{5}, 336.1805$; found 336.1820 . 


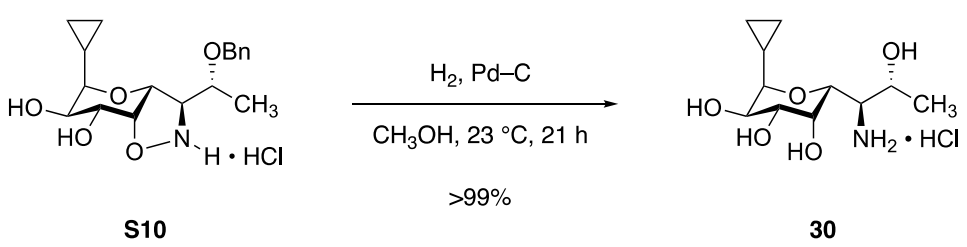

\section{Aminotetraol 30.}

A 2-5-mL glass microwave vial was charged with a magnetic stir bar, isoxazolidine salt S10 $\cdot \mathrm{HCl}(38 \mathrm{mg}, 0.10 \mathrm{mmol}, 1$ equiv), methanol $(1.0 \mathrm{~mL})$ and palladium on carbon $(10 \% \mathrm{w} / \mathrm{w}$, $11 \mathrm{mg}$ ). The headspace above the reaction mixture was flushed with hydrogen gas, and the mixture was stirred at $23{ }^{\circ} \mathrm{C}$ under a baloonful of hydrogen gas. After $21 \mathrm{~h}$, LCMS analysis indicated that isoxazolidine hydrogenolysis and $O$-debenzylation were complete; the mixture was filtered through a Celite pad, and the filter cake was rinsed with methanol $(3 \times 1 \mathrm{~mL})$. The filtrate was concentrated to afford analytically pure product (30) as a white solid (32 $\mathrm{mg}, 111 \%)$.

${ }^{1} \mathrm{H}$ NMR (600 MHz, CD 3 OD) $\delta 4.18(\operatorname{app~t}, J=2.3 \mathrm{~Hz}, 1 \mathrm{H}), 4.12(\operatorname{app~p}, J=6.3 \mathrm{~Hz}, 1 \mathrm{H}), 4.06$ (dd, $J=7.4,2.4 \mathrm{~Hz}, 1 \mathrm{H}), 3.96(\mathrm{dd}, J=8.7,5.0 \mathrm{~Hz}, 1 \mathrm{H}), 3.89(\mathrm{dd}, J=8.7,3.2 \mathrm{~Hz}, 1 \mathrm{H}), 3.55$ (app t, $J=6.4 \mathrm{~Hz}, 1 \mathrm{H}), 3.11(\mathrm{dd}, J=9.9,5.0 \mathrm{~Hz}, 1 \mathrm{H}), 1.29(\mathrm{~d}, J=6.4 \mathrm{~Hz}, 3 \mathrm{H}), 1.15($ app ddq, $J=12.9,9.3,4.8 \mathrm{~Hz}, 1 \mathrm{H}), 0.71(\mathrm{tdd}, J=8.5,5.9,4.4 \mathrm{~Hz}, 1 \mathrm{H}), 0.53($ app tt, $J=9.1$, $5.3 \mathrm{~Hz}, 1 \mathrm{H}), 0.35(\mathrm{dq}, J=9.7,4.8 \mathrm{~Hz}, 1 \mathrm{H}), 0.29(\mathrm{dq}, J=9.6,4.9 \mathrm{~Hz}, 1 \mathrm{H})$.

${ }^{13} \mathrm{C}$ NMR $\left(100 \mathrm{MHz}, \mathrm{CD}_{3} \mathrm{OD}\right) \delta 82.0,71.9,70.5,69.9(2 \times \mathrm{C}), 65.6,58.2,18.4,93,5.9,2.6$. FTIR (neat, $\mathrm{cm}^{-1}$ ): 3350 (br), 2925 (m), 1620 (w), 1510 (m), 1094 (s), 1072 (s), 1002 (m). HRMS (ESI+, $m / z):[\mathrm{M}+\mathrm{H}]^{+}$calc'd for $\mathrm{C}_{11} \mathrm{H}_{21} \mathrm{NO}_{5}, 248.1492$; found 248.1498 . 


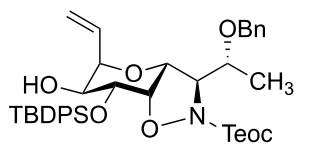

28

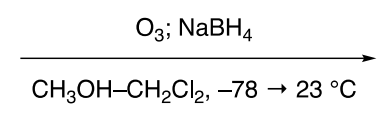

$98 \%$

\section{Hydroxymethyl glycoside S11.}

A solution of 28 (654 mg, $0.929 \mathrm{mmol}, 1$ equiv) in 50\% v/v dichloromethane-methanol (18.6 mL) was chilled to $-78{ }^{\circ} \mathrm{C}$. A mixture of ozone and dioxygen from an ozone generator was bubbled gently through the reaction solution, until an azure color appeared and persisted for 15 seconds, signaling saturation of the solution with ozone gas with concomitant disappearance of starting material. Ozone bubbling was then discontinued, and nitrogen gas was bubbled through the solution for 5 minutes in order to flush the solution of residual ozone. The resulting colorless solution was treated with sodium borohydride ( $351 \mathrm{mg}, 9.29 \mathrm{mmol}, 10.0$ equiv) at $-78{ }^{\circ} \mathrm{C}$, and the mixture was subsequently allowed to warm to $23{ }^{\circ} \mathrm{C}$ with constant stirring (Note: gas evolution occurs upon warming, and the reaction flask should be adequately vented to avoid overpressurization). After stirring for $1 \mathrm{~h}$ at $23{ }^{\circ} \mathrm{C}$, the mixture was carefully treated with $30 \mathrm{~mL}$ of half-saturated aqueous sodium chloride solution (Caution: gas evolution!). The resulting mixture was stirred for 5 minutes, or until gas evolution ceased; and the mixture was then extracted with ethyl acetate $(3 \times 20 \mathrm{~mL})$. The combined organic extracts were washed with saturated aqueous sodium chloride solution, the washed solution was dried over sodium sulfate, and the dried solution was concentrated to afford $\mathbf{S 1 1}$ as a brilliant white solid (644 $\mathrm{mg}, 98 \%)$. This material was suitable for use without further purification.

$\mathrm{R}_{f}=0.34$ (40\% ethyl acetate-hexanes, UV+CAM). 
${ }^{1} \mathrm{H}$ NMR $\left(500 \mathrm{MHz}, \mathrm{CDCl}_{3}\right) \delta 7.78-7.75(\mathrm{~m}, 2 \mathrm{H}), 7.69-7.66(\mathrm{~m}, 2 \mathrm{H}), 7.46-7.41(\mathrm{~m}, 2 \mathrm{H}), 7.40-$ $7.35(\mathrm{~m}, 4 \mathrm{H}), 7.25-7.22(\mathrm{~m}, 3 \mathrm{H}), 7.17-7.13(\mathrm{~m}, 2 \mathrm{H}), 4.51(\mathrm{~d}, J=11.6 \mathrm{~Hz}, 1 \mathrm{H}), 4.39(\mathrm{~d}, J$ $=3.1 \mathrm{~Hz}, 1 \mathrm{H}), 4.35-4.26(\mathrm{~m}, 4 \mathrm{H}), 4.03(\mathrm{t}, J=3.3 \mathrm{~Hz}, 1 \mathrm{H}), 4.00(\operatorname{app~q}, J=5.9 \mathrm{~Hz}, 1 \mathrm{H})$, $3.95(\mathrm{~d}, J=5.2 \mathrm{~Hz}, 1 \mathrm{H}), 3.92(\mathrm{dd}, J=8.8,3.3 \mathrm{~Hz}, 1 \mathrm{H}), 3.67(\mathrm{dd}, J=11.9,4.7 \mathrm{~Hz}, 1 \mathrm{H})$, $3.61(\operatorname{app} t \mathrm{tt}, J=11.8,6.7 \mathrm{~Hz}, 2 \mathrm{H}), 2.06(\mathrm{~s}, 1 \mathrm{H}), 1.89(\mathrm{~s}, 1 \mathrm{H}), 1.24(\mathrm{~d}, J=6.4 \mathrm{~Hz}, 3 \mathrm{H}), 1.09$ (s, 9H), $1.07(\mathrm{~m}, 2 \mathrm{H}), 0.08(\mathrm{~s}, 9 \mathrm{H})$.

${ }^{13} \mathrm{C}$ NMR $\left(126 \mathrm{MHz}, \mathrm{CDCl}_{3}\right) \delta 157.4,138.1,136.2,135.8,133.4,133.1,130.2,130.2,128.5$, $128.1,128.0,127.9,127.9,79.6,76.2,75.4,73.2,72.0,71.9,71.8,70.2,64.9,59.9,27.1$, $19.5,17.7,17.3,-1.2$.

FTIR (neat, $\mathrm{cm}^{-1}$ ): 3452 (br), 2953 (m), 2933 (m), 2857 (m), 1703 (m), 1428 (m), 1250 (m), 1112 (s), $1085(\mathrm{~m}), 359(\mathrm{~m}), 838(\mathrm{~m}), 702(\mathrm{~s})$.

HRMS (ESI+, $m / z):[\mathrm{M}+\mathrm{H}]^{+}$calc'd for $\mathrm{C}_{38} \mathrm{H}_{53} \mathrm{NO}_{8} \mathrm{Si}_{2}, 708.3382$; found 708.3366. 


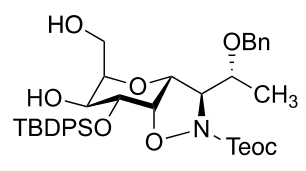

S11

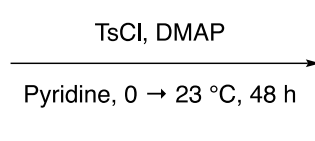

$90 \%$

\section{para-Toluenesulfonate ester S12.}

A flame-dried 25-mL round-bottomed flask was charged with diol S11 (1.05 g, $1.48 \mathrm{mmol}$, 1 equiv), and this starting material was dried by azeotropic removal of benzene. Anhydrous pyridine $(5.0 \mathrm{~mL})$ was then added, and the resulting solution was chilled to $0{ }^{\circ} \mathrm{C}$. Solid $p$ toluenesulfonyl chloride (481 mg, $2.52 \mathrm{mmol}, 1.70$ equiv) was added to the ice-cold solution, causing a golden yellow color to evolve. 4-Dimethylaminopyridine (DMAP, $9.1 \mathrm{mg}, 74 \mu \mathrm{mol}$, 0.050 equiv) was then added, and the resulting solution was stirred at $0{ }^{\circ} \mathrm{C}$ for 5 minutes; the cooling bath was then removed, and the mixture was allowed to warm to $23{ }^{\circ} \mathrm{C}$ with constant stirring. The golden color dissipated within 30 minutes, leaving a colorless solution. Progress was monitored by TLC (60\% ethyl acetate-hexanes, UV+CAM), and after $48 \mathrm{~h}$, the reaction was judged to be complete. The mixture was concentrated in vacuo, and the residue was purified by flash-column chromatography (80 g silica, eluting with $10 \%$ ethyl acetate-hexanes initially, grading to $30 \%$ ethyl acetate-hexanes) to give $\mathbf{S 1 2}$ as a white foaming solid (1.15 g, 90\%).

$\mathrm{R}_{f}=0.49$ (30\% ethyl acetate-hexanes, UV+CAM).

${ }^{1} \mathrm{H}$ NMR $\left(500 \mathrm{MHz}, \mathrm{CDCl}_{3}\right) \delta$ 7.75-7.72 (m, 2H), 7.68-7.64 (m, 4H), 7.46-7.41 (m, 2H), 7.39$7.34(\mathrm{~m}, 4 \mathrm{H}), 7.26-7.22(\mathrm{~m}, 3 \mathrm{H}), 7.19-7.16(\mathrm{~m}, 2 \mathrm{H}), 4.51(\mathrm{~d}, J=11.7 \mathrm{~Hz}, 1 \mathrm{H}), 4.44(\mathrm{~d}, J$ $=2.8 \mathrm{~Hz}, 1 \mathrm{H}), 4.30(\mathrm{~d}, J=11.8 \mathrm{~Hz}, 1 \mathrm{H}), 4.28-4.24(\mathrm{~m}, 3 \mathrm{H}), 4.10-4.00(\mathrm{~m}, 3 \mathrm{H}), 3.96(\mathrm{t}, J$ $=3.2 \mathrm{~Hz}, 1 \mathrm{H}), 3.93(\mathrm{~d}, J=5.4 \mathrm{~Hz}, 1 \mathrm{H}), 3.83(\mathrm{dd}, J=9.2,3.4 \mathrm{~Hz}, 1 \mathrm{H}), 3.57(\operatorname{app} \mathrm{p}, J=6.2$ 
$\mathrm{Hz}, 1 \mathrm{H}), 2.41(\mathrm{~s}, 3 \mathrm{H}), 1.86(\mathrm{~d}, J=3.7 \mathrm{~Hz}, 1 \mathrm{H}), 1.22(\mathrm{~d}, J=6.3 \mathrm{~Hz}, 3 \mathrm{H}), 1.07$ (s, 9H), 1.07$1.03(\mathrm{~m}, 2 \mathrm{H}), 0.07(\mathrm{~s}, 9 \mathrm{H})$.

${ }^{13} \mathrm{C}$ NMR $\left(126 \mathrm{MHz}, \mathrm{CDCl}_{3}\right) \delta 157.5,144.9,138.2,136.1,135.7,133.4,133.0,132.9,130.2$, $129.9,128.5,128.2,128.0,127.9,127.8,79.4,77.4,77.2,76.9,76.0,73.9,73.0,72.2,71.7$ $71.5,68.5,66.0,64.8,27.0,21.8,19.5,17.7,17.1,-1.3,-1.5$.

FTIR (neat, $\mathrm{cm}^{-1}$ ): 2954 (m), 2931 (m), 2896 (m), 2858 (m), 1707 (m), 1362 (m), 1177 (s), 1098 (s), $837(\mathrm{~s}), 703(\mathrm{~s})$.

HRMS (ESI+, $m / z)$ : $[\mathrm{M}+\mathrm{Na}]^{+}$calc'd for $\mathrm{C}_{45} \mathrm{H}_{59} \mathrm{NO}_{10} \mathrm{SSi}_{2}, 884.3290$; found 884.3262. 


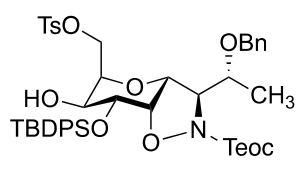

S12

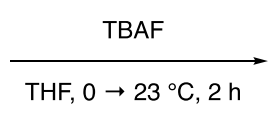

$79 \%$

\section{Isoxazolidine diol S13.}

In a 100-mL round-bottomed flask, a solution of carbamate $\mathbf{S 1 2}$ (1.15 g, 1.34 mmol, 1 equiv) in tetrahydrofuran $(13.4 \mathrm{~mL})$ was chilled to $0{ }^{\circ} \mathrm{C}$ was treated with tetrabutylammonium fluoride (1.0 M solution in tetrahydrofuran, $4.0 \mathrm{~mL}, 4.0 \mathrm{mmol}, 3.0$ equiv). Following the addition of TBAF, the ice-water cooling bath was removed, and the reaction solution was allowed to warm to $23{ }^{\circ} \mathrm{C}$. Progress was monitored by LCMS; cleavage of the (trimethylsilyl)ethyl carbamate was observed within 15 minutes, while cleavage of the tert-butyldiphenylsilyl ether was comparatively slower. After 2 hours, the reaction was judged to be complete, and $20 \mathrm{~mL}$ of saturated aqueous sodium bicarbonate solution was added. The resulting mixture was extracted with dichloromethane $(4 \times 15 \mathrm{~mL})$, and the combined organic layers were dried over sodium sulfate. The dried product solution was filtered, and the filtrate was concentrated to afford a colorless oil. This material was purified by flash-column chromatography (40 g silica, eluting with $1 \%$ methanol-dichloromethane initially, grading to $10 \%$ methanol-dichloromethane) to give $\mathbf{S 1 3}$ as a white foaming solid (508 mg, 79\%).

$\mathrm{R}_{f}=0.52(10 \%$ methanol-dichloromethane, UV+CAM).

${ }^{1} \mathrm{H}$ NMR $\left(600 \mathrm{MHz}, \mathrm{CDCl}_{3}\right) \delta 7.76(\mathrm{~d}, J=8.3 \mathrm{~Hz}, 2 \mathrm{H}), 7.34-7.30(\mathrm{~m}, 2 \mathrm{H}), 7.29-7.25(\mathrm{~m}, 5 \mathrm{H})$, $4.70(\mathrm{dd}, J=4.1,2.1 \mathrm{~Hz}, 1 \mathrm{H}), 4.61(\mathrm{~d}, J=11.6 \mathrm{~Hz}, 1 \mathrm{H}), 4.32(\mathrm{~d}, J=11.7 \mathrm{~Hz}, 1 \mathrm{H}), 4.26-$ $4.21(\mathrm{~m}, 2 \mathrm{H}), 4.18(\mathrm{app} \mathrm{dt}, J=6.9,5.0 \mathrm{~Hz}, 1 \mathrm{H}), 3.97(\mathrm{dd}, J=8.4,5.3 \mathrm{~Hz}, 1 \mathrm{H}), 3.88$ (app 
$\mathrm{t}, J=4.0 \mathrm{~Hz}, 1 \mathrm{H}), 3.79(\mathrm{dd}, J=8.4,3.8 \mathrm{~Hz}, 1 \mathrm{H}), 3.57($ br s, $1 \mathrm{H}), 3.23(\mathrm{dd}, J=3.9,2.1 \mathrm{~Hz}$, 1H), $2.39(\mathrm{~s}, 3 \mathrm{H}), 1.27(\mathrm{~d}, J=6.3 \mathrm{~Hz}, 3 \mathrm{H})$.

${ }^{13} \mathrm{C} \mathrm{NMR}\left(126 \mathrm{MHz}, \mathrm{CDCl}_{3}\right) \delta 144.9,138.0,132.9,130.0,128.6,128.0,128.0,127.8,81.7$ (br), 78.4, 72.9, 71.9, 70.9, 70.6, 70.1, 69.1, 67.2, 21.7, 16.9.

FTIR (neat, $\mathrm{cm}^{-1}$ ): 3378 (br), 2929 (w), 1453 (w), 1356 (m), 1174 (s), 1071 (s), 974 (m), 732 (s). HRMS (ESI+, m/z): $[\mathrm{M}+\mathrm{H}]^{+}$calc'd for $\mathrm{C}_{23} \mathrm{H}_{29} \mathrm{NO}_{8} \mathrm{~S}$, 480.1687; found 480.1711 . 


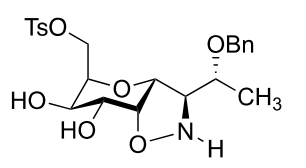

S13

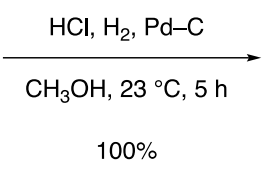

$100 \%$

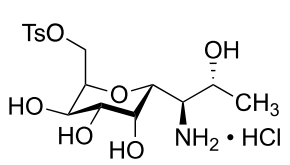

31

\section{Aminotetraol 31.}

In a 25-mL round-bottomed flask, a solution of isoxazolidine $\mathbf{S 1 3}$ (368 mg, $767 \mu \mathrm{mol}, 1$ equiv) in methanol $(8.00 \mathrm{~mL})$ was cooled to $0{ }^{\circ} \mathrm{C}$ and was treated with hydrogen chloride solution (4.0 $\mathrm{M}$ in 1,4-dioxane, $770 \mu \mathrm{L}, 3.1 \mathrm{mmol}, 4.0$ equiv). This solution was immediately concentrated to dryness, and the white residue obtained was re-dissolved in fresh methanol $(7.67 \mathrm{~mL})$. This solution was treated with palladium on carbon $(10 \% \mathrm{w} / \mathrm{w}, 82.0 \mathrm{mg})$, the headspace of the flask was flushed with nitrogen gas, and the apparatus was fitted with a 3-way stopcock to which one arm was affixed to a high-vacuum line, and the other was affixed to a hydrogen gas-filled balloon. The headspace of the flask was replaced by briefly evacuating, then back-filling the flask with hydrogen gas using the stopcock (3 evacuation-backfill cycles), and the black suspension was stirred at $23{ }^{\circ} \mathrm{C}$ under 1 atm of hydrogen gas. After $5 \mathrm{~h}$, LCMS analysis indicated that isoxazolidine ring and benzyl ether hydrogenolysis were complete, and the headspace of the flask was flushed with nitrogen gas. The reaction mixture was filtered through a Celite pad, and the filter cake was rinsed with methanol $(2 \times 3 \mathrm{~mL})$. The filtrate was concentrated to give the product $(\mathbf{3 1})$ as a dull white crystalline solid (327 mg, 100\%). This material was suitable for use in subsequent transformations without further purification.

Crystals suitable for X-ray analysis were prepared as follows: In a 1-mL glass sample vial, $31 \cdot \mathrm{HCl}(3 \mathrm{mg})$ was deposited, and this material was dissolved in approximately $200 \mu \mathrm{L}$ of 190 proof ethanol. The vial containing the ethanolic solution was then placed inside a $20-\mathrm{mL}$ scintillation vial containing approximately $3 \mathrm{~mL}$ of acetonitrile. The large vial was capped, and 
the assembly was allowed to stand undisturbed at $23^{\circ} \mathrm{C}$. After 2 days, needle-shaped crystals had formed.

${ }^{1} \mathrm{H}$ NMR $\left(600 \mathrm{MHz}, \mathrm{CD}_{3} \mathrm{OD}\right) \delta 7.80(\mathrm{~d}, J=8.0 \mathrm{~Hz}, 2 \mathrm{H}), 7.46(\mathrm{~d}, J=8.0 \mathrm{~Hz}, 2 \mathrm{H}), 4.35(\mathrm{dd}, J=$ 11.7, 9.6 Hz, 1H), 4.24-4.21 (m, 2H), 4.18 (app s, 1H), 4.09 (app p, $J=6.3 \mathrm{~Hz}, 1 \mathrm{H}), 3.99$ $(\mathrm{dd}, J=7.1,2.8 \mathrm{~Hz}, 1 \mathrm{H}), 3.95(\mathrm{dd}, J=8.3,5.0 \mathrm{~Hz}, 1 \mathrm{H}), 3.66(\mathrm{dd}, J=8.3,3.0 \mathrm{~Hz}, 1 \mathrm{H}), 3.56$ (app t, $J=6.4 \mathrm{~Hz}, 1 \mathrm{H}), 2.46(\mathrm{~s}, 3 \mathrm{H}), 1.26(\mathrm{~d}, J=6.4 \mathrm{~Hz}, 3 \mathrm{H})$.

${ }^{13} \mathrm{C}$ NMR (126 MHz, CD 3 OD) $\delta$ 146.7, 134.3, 131.2, 129.0, 74.0, 71.7, 69.8, 69.5, 68.7, 68.1, 65.5, $58.1,21.6,18.7$.

FTIR (neat, $\mathrm{cm}^{-1}$ ): 3345 (br), 2927 (br), 1598 (w), 1495 (w), 1356 (m), 1190(m), 1175 (s), 1080 (s), $976(\mathrm{~m}), 554(\mathrm{~m})$.

HRMS (ESI+, $m / z)$ : $[\mathrm{M}+\mathrm{Na}]^{+}$calc'd for $\mathrm{C}_{16} \mathrm{H}_{25} \mathrm{NO}_{8} \mathrm{~S}, 414.1193$; found 414.1203 . 


\section{Synthesis of the Fully Synthetic Lincosamide 37}

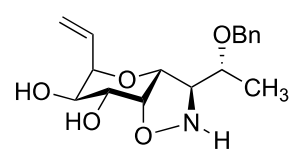

S8

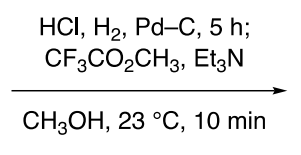

$63 \%$

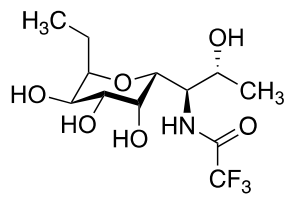

32

Trifluoroacetamide 32.

In a 10-mL glass microwave vial, an ice-cold solution of isoxazolidine $\mathbf{S 8}$ (66 mg, 0.21 mmol, 1 equiv) in methanol $(2.1 \mathrm{~mL})$ was treated with hydrogen chloride solution $(4.0 \mathrm{M}$ in 1,4 dioxane, $210 \mu \mathrm{L}, 0.82 \mathrm{mmol}, 4.0$ equiv). This mixture was immediately concentrated to dryness to provide the hydrochloride salt of the starting material, which was re-dissolved in methanol (2.1 $\mathrm{mL})$. This solution was then treated with palladium on carbon $(10 \% \mathrm{w} / \mathrm{w}, 22 \mathrm{mg})$, the headspace of the reaction flask was replaced with hydrogen gas, and the black suspension was stirred under hydrogen gas $(1 \mathrm{~atm})$ at $23{ }^{\circ} \mathrm{C}$ for $5 \mathrm{~h}$, at which point LCMS analysis indicated that olefin saturation, isoxazolidine hydrogenolysis, and debenzylation were all complete. Triethylamine (140 $\mu \mathrm{L}, 1.0 \mathrm{mmol}, 5.0$ equiv) was added to basify the reaction mixture, and methyl trifluoroacetate (100 $\mu \mathrm{L}, 1.0 \mathrm{mmol}, 5.0$ equiv) was added to protect the primary amine that had been generated in the hydrogenolytic operation. After $10 \mathrm{~min}$ of stirring at $23{ }^{\circ} \mathrm{C}$, LCMS analysis indicated that trifluoroacetylation was complete, and the mixture was filtered through a pad of Celite to remove the heterogeneous catalyst. The filter cake was rinsed with methanol $(3 \times 1 \mathrm{~mL})$, and the filtrate was concentrated in vacuo to give a white solid containing crude product contaminated with triethylamine hydrochloride. The latter was removed as follows: the crude product mixture was partitioned between ethyl acetate $(15 \mathrm{~mL})$ and saturated aqueous sodium chloride solution (15 $\mathrm{mL})$. The layers were shaken, then separated. The organic layer was washed with a fresh portion of saturated aqueous sodium chloride solution. These combined aqueous washes were then themselves extracted with fresh ethyl acetate $(2 \times 10 \mathrm{~mL})$, and the combined organic extracts $(35$ 
$\mathrm{mL}$ in total) were dried over sodium sulfate. The dried product solution was filtered, and the filtrate was concentrated to give pure trifluoroacetamide 32 as a white solid (43 $\mathrm{mg}, 63 \%$ ).

${ }^{1} \mathrm{H}$ NMR $\left(500 \mathrm{MHz}, \mathrm{CD}_{3} \mathrm{OD}\right) \delta 4.20(\operatorname{app~t}, J=7.0 \mathrm{~Hz}, 1 \mathrm{H}), 4.10(\mathrm{qd}, J=7.1,1.7 \mathrm{~Hz}, 1 \mathrm{H}), 4.01-$ $3.96(\mathrm{~m}, 2 \mathrm{H}), 3.88-3.82(\mathrm{~m}, 2 \mathrm{H}), 1.70-1.60(\mathrm{~m}, 2 \mathrm{H}), 1.17(\mathrm{dd}, J=6.4,1.7 \mathrm{~Hz}, 3 \mathrm{H}), 0.96$ $(\mathrm{t}, J=6.8 \mathrm{~Hz}, 3 \mathrm{H})$.

${ }^{19} \mathrm{~F}$ NMR (471 MHz, CD $\left.3 \mathrm{OD}\right) \delta-77.51(\mathrm{~s}, 3 \mathrm{~F})$.

MS (ESI-, m/z): [M-H] $]^{-}$calc'd for $\mathrm{C}_{12} \mathrm{H}_{20} \mathrm{~F}_{3} \mathrm{NO}_{6}, 330.1$; found 330.1. 


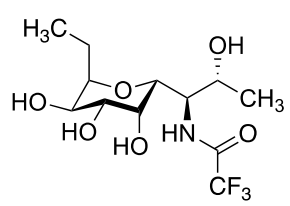

32

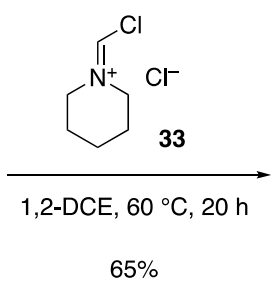

$65 \%$

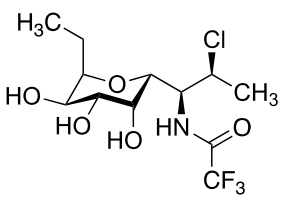

S14

\section{Chloro compound S14.}

In a 2-5-mL glass microwave vial, an ice-cold heterogeneous mixture of tetraol S32 (44 mg, $\quad 0.13$ mmol, 1 equiv) and 1,2-dichloroethane $(2.2 \mathrm{~mL})$ was treated with 1(chloromethylene)pipiridin-1-ium chloride $(33,130 \mathrm{mg}, 0.80 \mathrm{mmol}, 6.0$ equiv). The vial was sealed, and the mixture was stirred at $0{ }^{\circ} \mathrm{C}$ for $15 \mathrm{~min}$, during which time the originally lightyellow suspension clarified to form a light-yellow solution. The mixture was then heated to $60{ }^{\circ} \mathrm{C}$

for $21 \mathrm{~h}$, at which point LCMS analysis showed that deoxychlorination was complete, as evidenced by the disappearance of (oligo)formylated starting material congeners $\left(\mathrm{ESI}-,[\mathrm{M}-\mathrm{H}]^{-} \mathrm{m} / \mathrm{z}=358\right.$, $386,414)$. The mixture was chilled to $0{ }^{\circ} \mathrm{C}$, and excess Vilsmeier reagent was quenched with the addition of aqueous sodium hydroxide solution $(0.50 \mathrm{M}, 1.60 \mathrm{~mL}, 0.80 \mathrm{mmol}, 6.0$ equiv). The resulting aqueous layer was still acidic, so additional sodium hydroxide solution $(0.50 \mathrm{M})$ was added to achieve (and maintain) $\mathrm{pH} \sim 10$. The biphasic mixture was warmed to $23{ }^{\circ} \mathrm{C}$ with rapid stirring, and saponification of pendant formyl groups was monitored by LCMS. After 18 h, deformylation was complete. The layers were separated, and the aqueous phase was then treated with sodium chloride to the point of saturation, in order to diminish the product's solubility in that medium. The resulting aqueous mixture was then extracted with dichloromethane $(5 \times 2 \mathrm{~mL})$, until no product could be detected in the aqueous phase by LCMS. The combined organic extracts were dried over sodium sulfate, the dried solution was filtered, and the filtrate was concentrated. The crude residue thus obtained was purified by flash-column chromatography ( $4 \mathrm{~g}$ silica gel, eluting 
with dichloromethane initially, grading to 7\% methanol-dichloromethane) to provide $\mathbf{S 1 4}$ as a white solid (30 mg, 65\%).

$\mathrm{R}_{f}=0.31$ (10\% methanol-dichloromethane, CAM).

${ }^{1} \mathrm{H}$ NMR (500 MHz, CD $\left.3 \mathrm{OD}\right) \delta 4.63(\mathrm{qd}, J=6.9,1.7 \mathrm{~Hz}, 1 \mathrm{H}), 4.50(\mathrm{dd}, J=9.8,1.6 \mathrm{~Hz}, 1 \mathrm{H}), 3.97$ (dd, $J=10.1,6.3 \mathrm{~Hz}, 1 \mathrm{H}), 3.87-3.83(\mathrm{~m}, 2 \mathrm{H}), 3.77(\mathrm{dd}, J=3.3,1.3 \mathrm{~Hz}, 1 \mathrm{H}), 3.56(\mathrm{dd}, J=$ $10.2,3.3 \mathrm{~Hz}, 1 \mathrm{H}), 1.73-1.62(\mathrm{~m}, 2 \mathrm{H}), 1.44(\mathrm{~d}, J=6.9 \mathrm{~Hz}, 3 \mathrm{H}), 1.02(\mathrm{t}, J=7.4 \mathrm{~Hz}, 3 \mathrm{H})$.

${ }^{13} \mathrm{C}$ NMR (126 MHz, CD $\left.{ }_{3} \mathrm{OD}\right) \delta 80.5,71.9,70.0,69.9,69.5,58.9,55.3,23.1,17.5,11.2$. Trifluoroacetamide carbons were not resolved due to ${ }^{19} \mathrm{~F}$ nuclear coupling.

${ }^{19} \mathrm{~F}$ NMR $\left(471 \mathrm{MHz}, \mathrm{CD}_{3} \mathrm{OD}\right) \delta-76.74(\mathrm{~s}, 3 \mathrm{~F})$.

FTIR (neat, $\mathrm{cm}^{-1}$ ): 3365 (br), 2938 (w), 1712 (s), 1545 (w), 1212 (m), 1160 (s), 1079 (s), 963 (m). HRMS (ESI+, $m / z):[\mathrm{M}+\mathrm{H}]^{+}$calc'd for $\mathrm{C}_{12} \mathrm{H}_{19} \mathrm{ClF}_{3} \mathrm{NO}_{5}, 350.0977$; found 350.0981 . 

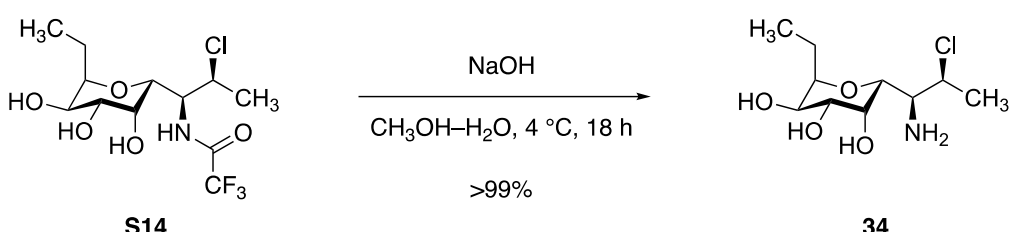

S14

34

\section{Aminotriol 34.}

In a 4-mL glass vial, trifluoroacetamide $\mathbf{S 1 4}(30 \mathrm{mg}, 86 \mu \mathrm{mol}, 1$ equiv) was dissolved in methanol $(50 \mu \mathrm{L})$. To this solution was then added ice-cold aqueous sodium hydroxide solution $(1.0 \mathrm{M}, 450 \mu \mathrm{L})$. Vigorous stirring was maintained, and the mixture was held at $4{ }^{\circ} \mathrm{C}$ for $18 \mathrm{~h}$, at which point LCMS analysis indicated that no starting material remained. The mixture was diluted with $400 \mu \mathrm{L}$ of ice-cold water, and the white suspension was filtered. This filter cake was washed with $300 \mu \mathrm{L}$ of ice-cold water before being dried in vacuo to provide a crop of pure crystalline product (13 mg, 60\%). The filtrate, containing additional aminotriol product, was acidified with the addition of aqueous hydrogen chloride solution $(1.0 \mathrm{M}, 500 \mu \mathrm{L})$ before it was concentrated to dryness to provide crude product as its hydrochloride salt, contaminated with sodium chloride. This solid was suspended in ethanol (190 proof, $1.0 \mathrm{~mL}$ ), and the supernatant (containing $\mathbf{S 3 4} \bullet$ $\mathrm{HCl}$ ) was transferred to a vial containing Amberlyst A26 resin (hydroxide form, $300 \mathrm{mg}$ ). This mixture was stirred at $0{ }^{\circ} \mathrm{C}$ for $30 \mathrm{~min}$ before the ion-exchange beads were removed by filtration. The filtrate was concentrated to provide additional product $\left(11 \mathrm{mg}\right.$, estimated $80 \%$ pure by ${ }^{1} \mathrm{H}$ NMR, 40\%).

${ }^{1} \mathrm{H}$ NMR $(500 \mathrm{MHz}, \mathrm{CD} 3 \mathrm{OD}) \delta 4.62(\mathrm{q}, J=6.7 \mathrm{~Hz}, 1 \mathrm{H}), 4.08(\operatorname{app~t}, J=2.6 \mathrm{~Hz}, 1 \mathrm{H}), 3.91(\mathrm{dd}, J$ $=9.4,5.7 \mathrm{~Hz}, 1 \mathrm{H}), 3.78(\operatorname{app~q}, J=6.8 \mathrm{~Hz}, 1 \mathrm{H}), 3.63(\mathrm{dd}, J=9.4,3.4 \mathrm{~Hz}, 1 \mathrm{H}), 3.48(\mathrm{dd}, J$ $=9.3,1.9 \mathrm{~Hz}, 1 \mathrm{H}), 3.10(\mathrm{~d}, J=9.2 \mathrm{~Hz}, 1 \mathrm{H}), 1.63(\operatorname{app} \mathrm{p}, J=7.4 \mathrm{~Hz}, 2 \mathrm{H}), 1.56(\mathrm{~d}, J=6.9$ $\mathrm{Hz}, 3 \mathrm{H}), 0.99$ (t, $J=7.4 \mathrm{~Hz}, 3 \mathrm{H})$. 
${ }^{13} \mathrm{C}$ NMR (100 MHz, CD 3 OD) $\delta$ 79.0, 72.9, 72.1, 70.2, 69.9, 61.0, 56.5, 22.7, 18.3, 11.1.

FTIR (neat, $\mathrm{cm}^{-1}$ ): 3300 (br), 2929 (w), 2464 (w), 1620 (w), 1076 (s), 963 (m).

HRMS (ESI+, $m / z):[\mathrm{M}+\mathrm{H}]^{+}$calc'd for $\mathrm{C}_{10} \mathrm{H}_{20} \mathrm{ClNO}_{4}, 254.1154$; found 254.1154. 

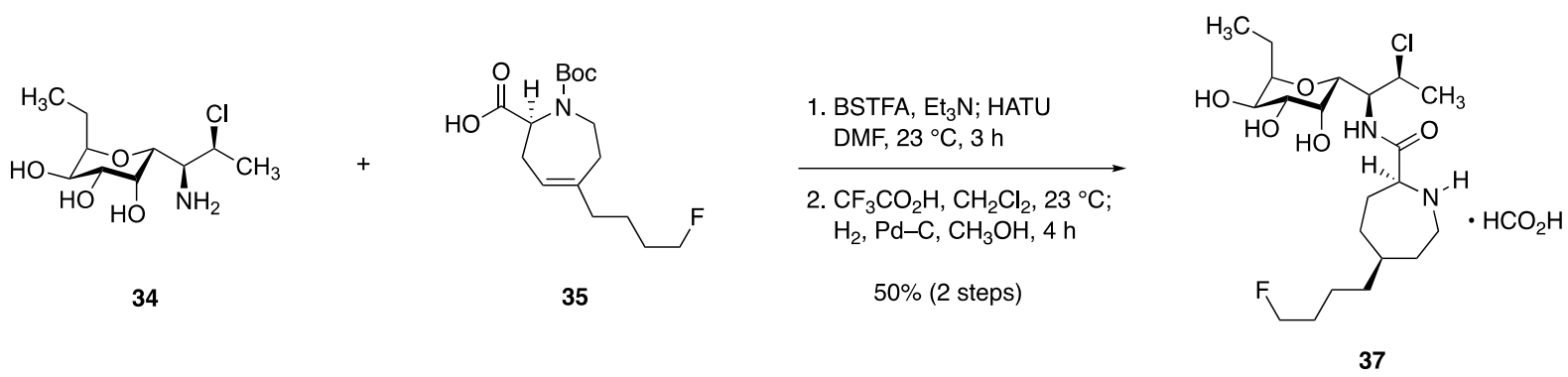

\section{Synthetic lincosamide 37.}

A solution of aminotriol $34(12.9 \mathrm{mg}, 51.0 \mu \mathrm{mol}, 1$ equiv) in $N, N$-dimethylformamide (254 $\mu \mathrm{L})$ was treated sequentially with triethylamine $(22.7 \mu \mathrm{L}, 163 \mu \mathrm{mol}, 3.20$ equiv) and $N, O$ bis(trimethylsilyl)trifluoroacetamide $\left(20.5 \mu \mathrm{L}, 76.0 \mu \mathrm{mol}, 1.50\right.$ equiv) at $23{ }^{\circ} \mathrm{C}$. The mixture was stirred for $1 \mathrm{~h}$ to ensure complete $O$-silylation before a solution of azepine acid $\mathbf{3 5}$ (17.6 mg, 56.0 $\mu$ mol, 1.10 equiv $)^{4}$ in $N, N$-dimethylformamide $(200 \mu \mathrm{L})$ was added. The reaction mixture was then treated with HATU (25.1 mg, $66.0 \mu \mathrm{mol}, 1.30$ equiv), and the lemon-yellow mixture was stirred at $23{ }^{\circ} \mathrm{C}$ for $3 \mathrm{~h}$. After this time, the reaction mixture was diluted with ethyl acetate $(20 \mathrm{~mL})$ and the diluted organic solution was washed sequentially with $10-\mathrm{mL}$ portions of $10 \% \mathrm{w} / \mathrm{v}$ aqueous citric acid solution, saturated aqueous sodium bicarbonate solution, and saturated aqueous sodium chloride solution. The washed organic layer was then dried over sodium sulfate, filtered, and concentrated. The dried residue was transferred to a 4-mL glass vial, where it was re-dissolved in $33 \%$ v/v trifluoroacetic acid-dichloromethane $(300 \mu \mathrm{L})$. Deprotection was monitored by LCMS, and after 15 min global trimethylsilyl and Boc removal was complete. The mixture was concentrated to dryness, and the residue was re-dissolved in methanol (300 mL). Palladium on carbon $(10 \% \mathrm{w} / \mathrm{w}, 20 \mathrm{mg})$ was added, the headspace above the black suspension was replaced with hydrogen gas, and the mixture was stirred at $23{ }^{\circ} \mathrm{C}$ for $4 \mathrm{~h}$, resulting in complete hydrogenation of the azepine, as indicated by LCMS. The mixture was filtered through a pad of Celite to remove the heterogeneous catalyst, and the filter cake was rinsed with methanol $(3 \times 1 \mathrm{~mL})$. The filtrate 
was concentrated to give a brown film, which was subjected to preparative HPLC-MS on a Waters SunFire Prep $\mathrm{C}_{18}$ column $(5 \mu \mathrm{m}, 250 \times 19 \mathrm{~mm}$; eluting with $0.1 \%$ formic acid $-5 \%$ acetonitrilewater initially, grading to $0.1 \%$ formic acid- $-40 \%$ acetonitrile--water over $40 \mathrm{~min}$, with a flow rate of $15 \mathrm{~mL} / \mathrm{min}$; monitored by UV absorbance at $210 \mathrm{~nm}$ and ESI+ selected ion monitoring $[\mathrm{m} / z=$ 453]) to provide the product $\left(\mathbf{3 7} \cdot \mathrm{HCO}_{2} \mathrm{H}, 3.0 \mathrm{mg}, 50 \%, 2\right.$ steps $)$ as a white solid.

${ }^{1} \mathrm{H}$ NMR $\left(600 \mathrm{MHz}, \mathrm{CD}_{3} \mathrm{OD}\right) \delta 8.42(\mathrm{~s}, 1 \mathrm{H}), 4.64(\mathrm{q}, J=6.8 \mathrm{~Hz}, 1 \mathrm{H}), 4.42(\mathrm{dt}, J=47.5,6.0 \mathrm{~Hz}$, $2 \mathrm{H}), 4.41(\mathrm{~d}, J=9.7 \mathrm{~Hz}, 1 \mathrm{H}), 4.10(\operatorname{app~t}, J=5.6 \mathrm{~Hz}, 1 \mathrm{H}), 3.96(\mathrm{dd}, J=10.1,6.3 \mathrm{~Hz}, 1 \mathrm{H})$, 3.85 (ddd, $J=10.1,6.2,3.2 \mathrm{~Hz}, 1 \mathrm{H}), 3.80$ (app s, 1H), 3.68 (d, $J=9.7 \mathrm{~Hz}, 1 \mathrm{H}), 3.57$ (dd, $J=10.3,3.0 \mathrm{~Hz}, 1 \mathrm{H}), 3.44(\mathrm{dd}, J=13.3,4.5 \mathrm{~Hz}, 1 \mathrm{H}), 3.13($ app t, $J=12.5 \mathrm{~Hz}, 1 \mathrm{H}), 2.25-$ $2.14(\mathrm{~m}, 2 \mathrm{H}), 2.02(\mathrm{br} \mathrm{d}, J=14.9 \mathrm{~Hz}, 1 \mathrm{H}), 1.94(\mathrm{ddd}, J=14.8,8.2,4.0 \mathrm{~Hz}, 1 \mathrm{H}), 1.72-1.61$ (m, 5H), 1.61-1.53 (m, 1H), 1.47-1.42 (m, 3H), $1.44(\mathrm{~d}, J=6.7 \mathrm{~Hz}, 3 \mathrm{H}), 1.37-1.33(\mathrm{~m}$, 2H), $1.02(\mathrm{t}, J=7.3 \mathrm{~Hz}, 3 \mathrm{H})$.

${ }^{13} \mathrm{C}$ NMR $\left(126 \mathrm{MHz}, \mathrm{CD}_{3} \mathrm{OD}\right) \delta 171.6,84.7(\mathrm{~d}, J=163.7 \mathrm{~Hz}), 80.4,71.8,70.6,69.9,69.6,60.5$, $59.3,55.0,45.6,38.9,37.4,33.3,31.6(\mathrm{~d}, J=19.6 \mathrm{~Hz}), 30.7,29.1,23.8(\mathrm{~d}, J=5.1 \mathrm{~Hz}, 1 \mathrm{H})$, 23.2, 17.4, 11.2.

FTIR (neat, $\mathrm{cm}^{-1}$ ): 3266 (br), 2934 (m), 1672 (m), 1590 (s), 1459 (m), 1378 (m), 1346 (m), 1084 (m).

HRMS (ESI+, $m / z):[\mathrm{M}+\mathrm{H}]^{+}$calc'd for $\mathrm{C}_{21} \mathrm{H}_{38} \mathrm{ClFN}_{2} \mathrm{O} 5$, 453.2526; found 453.2526. 


\section{Synthesis of 8-Norlincomycin (42)}

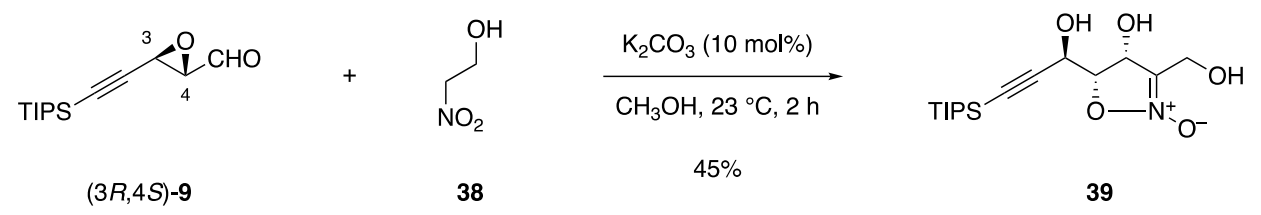

\section{Isoxazoline $N$-oxide 39.}

In a 100-mL round-bottomed flask, epoxyaldehyde (3R,4S)-9 (4.93 g, $19.5 \mathrm{mmol}, 1$ equiv) was dissolved in methanol $(39.1 \mathrm{~mL})$. To this solution were added nitroethanol $(2.80 \mathrm{~mL}, 39.1$ mmol, 2.0 equiv) and potassium carbonate ( $270 \mathrm{mg}, 1.95 \mathrm{mmol}, 0.100$ equiv). After stirring for 2 h at $23{ }^{\circ} \mathrm{C}$, TLC analysis (60\% ethyl acetate-hexanes, CAM) showed complete consumption of epoxyaldehyde starting material, as well as the disappearance of intermediate, linear, mid-polar nitroaldol adducts ( $\mathrm{R}_{f}$ 's $0.63-0.77$, 60\% ethyl acetate-hexanes, CAM). The mixture was concentrated in vacuo, and crude ${ }^{1} \mathrm{H}-\mathrm{NMR}$ analysis of the residue revealed a 62:38 diastereomeric ratio favoring the desired C5 epimer. This crude mixture was subjected to flash-column chromatographic separation (700 g silica gel, eluting with 50\% ethyl acetate-hexanes initially, grading to $80 \%$ ethyl acetate-hexanes) to afford isoxazoline $N$-oxide $\mathbf{3 9}$ as a brilliant white powder $(3.00 \mathrm{~g}, 45 \%)$.

Melting point: $55-57^{\circ} \mathrm{C}$.

$\mathrm{R}_{f}=0.38$ (ethyl acetate, CAM).

${ }^{1} \mathrm{H}$ NMR $\left(500 \mathrm{MHz}_{\mathrm{CDCl}}\right) \delta 5.51(\operatorname{app~t}, J=6.9 \mathrm{~Hz}, 1 \mathrm{H}), 4.89(\mathrm{dd}, J=6.6,5.0 \mathrm{~Hz}, 1 \mathrm{H}), 4.67$ $(\mathrm{dd}, J=7.4,5.0 \mathrm{~Hz}, 1 \mathrm{H}), 4.56-4.53(\mathrm{~m}, 2 \mathrm{H}), 3.42(\mathrm{~d}, J=6.6 \mathrm{~Hz}, 1 \mathrm{H}), 2.97(\mathrm{~d}, J=6.7 \mathrm{~Hz}$ 1H), $2.42(\mathrm{t}, J=6.3 \mathrm{~Hz}, 1 \mathrm{H}), 1.09-1.08(\mathrm{~m}, 21 \mathrm{H})$.

${ }^{13} \mathrm{C} \mathrm{NMR}\left(126 \mathrm{MHz}, \mathrm{CDCl}_{3}\right) \delta 118.7,103.0,89.8,79.7,74.8,60.6,55.2,18.7,11.2$. 
FTIR (neat, $\mathrm{cm}^{-1}$ ): 3357 (br), 2942 (s), 2865 (s), 1639 (s), 1463 (m), 1014 (s), 883 (s), 677 (s). HRMS (ESI+, $m / z)$ : $[\mathrm{M}+\mathrm{H}]^{+}$calc'd for $\mathrm{C}_{16} \mathrm{H}_{29} \mathrm{NO}_{5} \mathrm{Si}$, 366.1707; found 366.1703 . 


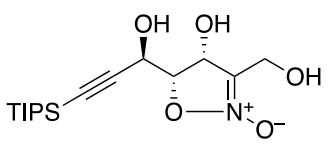

39

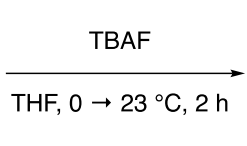

$97 \%$

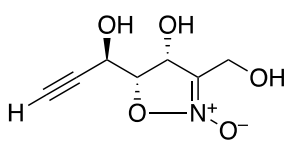

S15

\section{Triol S15.}

To a solution of isoxazoline $N$-oxide $39(4.70 \mathrm{~g}, 13.7 \mathrm{mmol}, 1$ equiv $)$ in tetrahydrofuran $(137 \mathrm{~mL})$ was added tetrabutylammonium fluoride solution (1.0 M in tetrahydrofuran, $32.8 \mathrm{~mL}$, $32.8 \mathrm{mmol}, 2.40$ equiv) dropwise at $0{ }^{\circ} \mathrm{C}$. The resulting colorless solution was immediately warmed to $23{ }^{\circ} \mathrm{C}$, and after $2 \mathrm{~h}$ of stirring at that temperature, TLC analysis (5\% methanol-ethyl acetate, CAM) indicated complete consumption of starting material. The mixture was loaded directly onto a column of silica gel (500 g) pre-equilibrated with ethyl acetate. The product was eluted with 5\% methanol-ethyl acetate, and product-containing fractions were pooled. The pooled fractions were concentrated to give S15 as a buff white solid (221 $\mathrm{mg}, 97 \%)$.

$\mathrm{R}_{f}=0.32$ (5\% methanol-ethyl acetate, CAM).

${ }^{1} \mathrm{H}$ NMR $\left(500 \mathrm{MHz}, \mathrm{CD}_{3} \mathrm{OD}\right) \delta 5.25(\mathrm{~d}, J=6.3 \mathrm{~Hz}, 1 \mathrm{H}), 4.73(\mathrm{dd}, J=8.1,2.2 \mathrm{~Hz}, 1 \mathrm{H}), 4.45(\mathrm{dd}$, $J=6.3,8.1 \mathrm{~Hz}, 1 \mathrm{H}), 4.43(\mathrm{~d}, J=14.6 \mathrm{~Hz}, 1 \mathrm{H}), 4.33(\mathrm{~d}, J=14.1 \mathrm{~Hz}, 1 \mathrm{H}), 2.91(\mathrm{~d}, J=2.2$ $\mathrm{Hz}, 1 \mathrm{H})$.

${ }^{13} \mathrm{C}$ NMR $\left(126 \mathrm{MHz}, \mathrm{CD}_{3} \mathrm{OD}\right) \delta 120.8,82.9,81.9,75.4,75.4,73.5,73.5,58.8,55.1$.

FTIR (neat, $\mathrm{cm}^{-1}$ ): 3279 (br), 2933 (w), 1639 (s), 1293 (m), 1092 (m), 1044 (m), 1019 (m). HRMS (ESI+, $m / z):[\mathrm{M}+\mathrm{H}]^{+}$calc'd for $\mathrm{C}_{7} \mathrm{H}_{9} \mathrm{NO}_{5}, 210.0373$; found 210.0370 . 


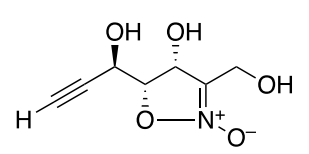

S15

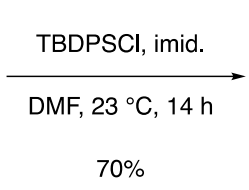

$70 \%$

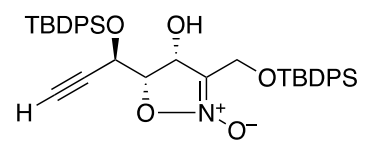

S16

\section{Bis-silyl ether S16.}

To a solution of triol S15 (2.35 g, $12.6 \mathrm{mmol}, 1$ equiv) and imidazole (4.27 g, $62.8 \mathrm{mmol}$, 8.00 equiv) in $N, N$-dimethylformamide $(62.8 \mathrm{~mL})$ was added tert-butyl(chloro)diphenylsilane (7.26 mL, $28.3 \mathrm{mmol}, 4.00$ equiv) dropwise at $0{ }^{\circ} \mathrm{C}$. The mixture was then warmed to $23{ }^{\circ} \mathrm{C}$. Silylation of the primary alcohol was fast (generally complete within $5 \mathrm{~min}$ ), while silylation of the propargylic alcohol was substantially slower. After $14 \mathrm{~h}$ of stirring at $23{ }^{\circ} \mathrm{C}$, TLC analysis (60\% ethyl acetate-hexanes, $\mathrm{UV}+\mathrm{KMnO}_{4}$ ) showed complete consumption of the mono-silylated intermediate $\left(\mathrm{R}_{f}=0.61\right)$. Excess chlorosilane reagent was quenched with the addition of saturated aqueous ammonium chloride $(100 \mathrm{~mL})$, and the resulting mixture was stirred rapidly at $23{ }^{\circ} \mathrm{C}$ for $10 \mathrm{~min}$. The mixture was then extracted with $20 \%$ ethyl acetate-hexanes $(4 \times 100 \mathrm{~mL})$; the organic extracts were then combined, washed with saturated aqueous sodium chloride solution (100 mL), dried over sodium sulfate, filtered, and concentrated to give a light golden-amber oil. This residue was purified by flash-column chromatography (500 g silica gel, eluting with hexanes initially, grading to 20\% ethyl acetate-hexanes) to provide S16 as a white, foaming, amorphous solid (5.87 g, 70\%).

$\mathrm{R}_{f}=0.39$ (20\% ethyl acetate-hexanes, $\mathrm{UV}+\mathrm{KMnO}_{4}$ ).

${ }^{1} \mathrm{H}$ NMR (500 MHz, $\left.\mathrm{CDCl}_{3}\right) \delta$ 7.80-7.78 (m, 2H), 7.76-7.71 (m, 6H), 7.51-7.46 (m, 4H), 7.45$7.40(\mathrm{~m}, 8 \mathrm{H}), 5.34($ app t, $J=7.7 \mathrm{~Hz}, 1 \mathrm{H}), 4.81(\mathrm{dd}, J=5.1,2.3 \mathrm{~Hz}, 1 \mathrm{H}), 4.64(\mathrm{~d}, J=13.7$ 
$\mathrm{Hz}, 1 \mathrm{H}), 4.57(\mathrm{~d}, J=13.8 \mathrm{~Hz}, 1 \mathrm{H}), 4.46(\mathrm{dd}, J=7.2,5.1 \mathrm{~Hz}, 1 \mathrm{H}), 3.38(\mathrm{~d}, J=8.1 \mathrm{~Hz}, 1 \mathrm{H})$, $2.47(\mathrm{~d}, J=2.3 \mathrm{~Hz}, 1 \mathrm{H}), 1.12(\mathrm{~s}, 18 \mathrm{H})$.

${ }^{13} \mathrm{C} \mathrm{NMR}\left(126 \mathrm{MHz}, \mathrm{CDCl}_{3}\right) \delta 136.2,136.0,135.6(2 \times \mathrm{C}), 132.6,132.5,132.1,131.6,130.5$, 130.3, $130.2(2 \times \mathrm{C}), 128.1(2 \times \mathrm{C}), 128.0,127.7,116.9,79.8,79.2,76.5,74.3,61.8,57.0$, $26.9(2 \times C), 19.4,19.3$.

FTIR (neat, $\mathrm{cm}^{-1}$ ): 2931 (w), 2858 (w), 1644 (m), 1427 (m), 1105 (s), 1082 (s), 699 (s).

HRMS (ESI+, m/z): $[\mathrm{M}+\mathrm{H}]^{+}$calc'd for $\mathrm{C}_{39} \mathrm{H}_{45} \mathrm{NO}_{5} \mathrm{Si}_{2}, 664.2909$; found 664.2900. 


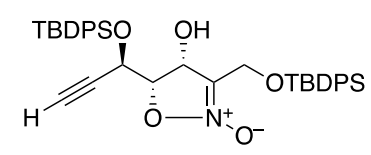

S16

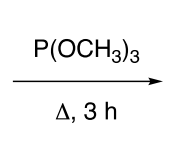

$72 \%$

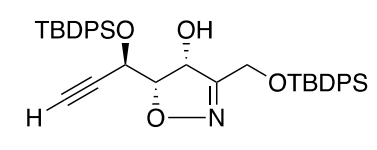

S17

\section{Isoxazoline $\mathbf{S 1 7 .}$}

In a 100-mL round-bottomed flask, isoxazoline $N$-oxide $\mathbf{S 1 6}$ (2.50 g, 3.77 mmol, 1 equiv) was dried by azeotropic removal of benzene. The dried starting material was then dissolved in trimethyl phosphite $(15.1 \mathrm{~mL})$, the flask was fitted with an oven-dried reflux condenser, and the reaction solution was heated to $100{ }^{\circ} \mathrm{C}$ in a pre-heated oil bath. After $3 \mathrm{~h}$, TLC analysis (20\% ethyl acetate-hexanes, PAA) showed complete consumption of starting material. The mixture was cooled to $0{ }^{\circ} \mathrm{C}$ and diluted in ethyl ether $(200 \mathrm{~mL})$; the organic product solution was then washed sequentially with $0.1 \mathrm{M}$ aqueous $\mathrm{HCl}$ solution $(2 \times 40 \mathrm{~mL})$ and saturated aqueous sodium chloride solution $(50 \mathrm{~mL})$. The washed organic solution was dried over sodium sulfate, filtered, and concentrated to give a light yellow foaming solid. This residue was purified by flash-column chromatography (220 g silica gel, eluting with hexanes initially, grading to $20 \%$ ethyl acetatehexanes) to provide $\mathbf{S 1 7}$ as a white, foaming, amorphous solid (1.76 g, 72\%).

$\mathrm{R}_{f}=0.47\left(20 \%\right.$ ethyl acetate-hexanes, $\left.\mathrm{UV}+\mathrm{KMnO}_{4}\right)$

${ }^{1} \mathrm{H}$ NMR $\left(600 \mathrm{MHz}, \mathrm{CDCl}_{3}\right) \delta$ 7.78-7.76 (m, 2H), 7.74-7.71 (m, 4H), 7.70-7.68 (m, 2H), 7.48$7.44(\mathrm{~m}, 4 \mathrm{H}), 7.42-7.39(\mathrm{~m}, 8 \mathrm{H}), 5.43(\operatorname{app~t}, J=8.8 \mathrm{~Hz}, 1 \mathrm{H}), 4.85(\mathrm{dd}, J=4.0,2.4 \mathrm{~Hz}$ $1 \mathrm{H}), 4.60(\mathrm{~d}, J=13.1 \mathrm{~Hz}, 1 \mathrm{H}), 4.56(\mathrm{~d}, J=12.9 \mathrm{~Hz}, 1 \mathrm{H}), 4.39(\mathrm{dd}, J=8.5,3.9 \mathrm{~Hz}, 1 \mathrm{H})$, $3.90(\mathrm{~d}, J=9.0 \mathrm{~Hz}, 1 \mathrm{H}), 2.48(\mathrm{~d}, J=2.3 \mathrm{~Hz}, 1 \mathrm{H}), 1.08(\mathrm{~s}, 9 \mathrm{H}), 1.06(\mathrm{~s}, 9 \mathrm{H})$. 
${ }^{13} \mathrm{C}$ NMR $\left(126 \mathrm{MHz}, \mathrm{CDCl}_{3}\right) \delta$ 159.9, $136.3(2 \times \mathrm{C}), 135.8,135.7,132.8(2 \times \mathrm{C}), 132.2,131.5$, $130.5,130.2,130.1(2 \times C), 128.0,128.0(3 \times C), 127.7,83.1,80.4,77.2,76.0,63.0,57.5$, $26.9(2 \times C), 19.4(2 \times C)$.

HRMS (ESI+, $m / z):[\mathrm{M}+\mathrm{H}]^{+}$calc'd for $\mathrm{C}_{39} \mathrm{H}_{45} \mathrm{NO}_{4} \mathrm{Si}_{2}, 648.2960$; found 648.2957. 


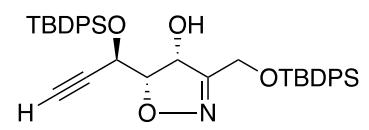

S17

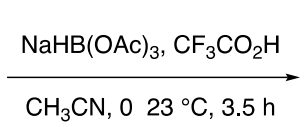

$\mathrm{CH}_{3} \mathrm{CN}, 023^{\circ} \mathrm{C}, 3.5 \mathrm{~h}$

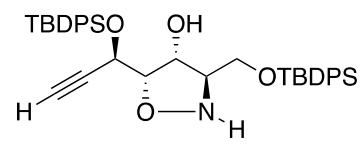

S18

\section{Isoxazolidine S18.}

To a rapidly stirred, ice-cold suspension of isoxazoline S17 (2.00 g, $3.09 \mathrm{mmol}, 1$ equiv) and sodium triacetoxyborohydride $(3.27 \mathrm{mg}, 15.4 \mathrm{mmol}, 5.00$ equiv) in acetonitrile $(25.7 \mathrm{~mL})$ was added trifluoroacetic acid $(23.8 \mathrm{~mL}, 309 \mathrm{mmol}, 100$ equiv) dropwise over $2 \mathrm{~min}$. The mixture was then warmed to $23{ }^{\circ} \mathrm{C}$, and over the course of $1.5 \mathrm{~h}$, the originally opaque white suspension gradually clarified, giving a light yellow, homogeneous solution. After 3.5, TLC analysis (20\% ethyl acetate-hexanes, PAA) showed full consumption of isoxazoline starting material. The reaction mixture was transferred by cannula to a rapidly stirred, ice-cold biphasic mixture of aqueous sodium hydroxide solution $(2.0 \mathrm{M}, 155 \mathrm{~mL}, 309 \mathrm{mmol})$ and dichloromethane $(155 \mathrm{~mL})$. Additional 2.0 M aqueous sodium hydroxide solution was added as necessary to achieve $\mathrm{pH} \geq 8.0$, and rapid stirring was maintained for $10 \mathrm{~min}$. The layers were then separated, and the aqueous layer was extracted with dichloromethane $(3 \times 75 \mathrm{~mL})$. The combined organic extracts were dried over sodium sulfate, filtered, and concentrated to give isoxazolidine $\mathbf{S 1 8}$ as a foaming, dull-white solid that was used in the next step without further purification.

For characterization purposes, a small quantity (ca. $25 \mathrm{mg}$ ) of crude residue was purified by HPLC on a Waters SunFire Prep $\mathrm{C}_{18}$ column $(5 \mu \mathrm{m}, 250 \times 19 \mathrm{~mm}$; eluting with $0.1 \%$ formic acid- $-25 \%$ acetonitrile-water initially, grading to $0.1 \%$ formic acid- $95 \%$ acetonitrile-water over $20 \mathrm{~min}$, then holding at $0.1 \%$ formic acid- $95 \%$ acetonitrile-water for 20 min with a flow rate of $15 \mathrm{~mL} / \mathrm{min}$; monitored by $\mathrm{UV}$ absorbance at $254 \mathrm{~nm} ; \mathrm{R}_{t}=31.9 \mathrm{~min}$ ) to give analytically pure sample with the following spectroscopic properties: 
${ }^{1} \mathrm{H}$ NMR $\left(500 \mathrm{MHz}, \mathrm{CDCl}_{3}\right) \delta$ 7.80-7.72 (m, 4H), 7.67-7.61 (m, 4H), 7.50-7.36 (m, 12H), 4.90 (dd, $J=5.3,2.9 \mathrm{~Hz}, 1 \mathrm{H}), 4.77(\mathrm{dd}, J=4.8,2.2 \mathrm{~Hz}, 1 \mathrm{H}), 3.94-3.88(\mathrm{~m}, 2 \mathrm{H}), 3.71(\mathrm{dd}, J=$ 11.0, $5.6 \mathrm{~Hz}, 1 \mathrm{H}), 3.43(\mathrm{dt}, J=6.4,3.6 \mathrm{~Hz}, 1 \mathrm{H}), 2.44(\mathrm{~d}, J=2.2 \mathrm{~Hz}, 1 \mathrm{H}), 1.11(\mathrm{~s}, 9 \mathrm{H}), 1.08$ $(\mathrm{s}, 9 \mathrm{H})$.

${ }^{13} \mathrm{C}$ NMR $\left(126 \mathrm{MHz}, \mathrm{CDCl}_{3}\right) \delta 136.3,136.1,135.7,135.6,132.9(2 \times \mathrm{C}), 132.3,132.0,130.4$ $130.3,130.1(2 \times \mathrm{C}), 128.0(3 \times \mathrm{C}), 127.8,127.7,81.1,77.7,75.8,70.9,63.1,61.0,27.0$ $(2 \times C), 19.4(2 \times C)$.

FTIR (neat, $\mathrm{cm}^{-1}$ ): $3288(\mathrm{w}), 2931(\mathrm{~m}), 2858(\mathrm{~m}), 1428(\mathrm{~m}), 1112(\mathrm{~s}), 701(\mathrm{~s})$.

HRMS (ESI+, $m / z):[\mathrm{M}+\mathrm{H}]^{+}$calc'd for $\mathrm{C}_{39} \mathrm{H}_{47} \mathrm{NO}_{4} \mathrm{Si}_{2}, 650.3116$; found 650.3119 . 


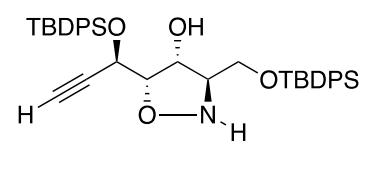

$\mathbf{S 1 8}$

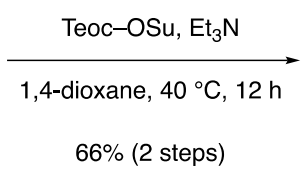

$66 \%$ (2 steps)

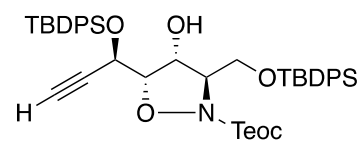

S19

\section{Carbamate S19.}

A solution of isoxazolidine $\mathbf{S 1 8}$ (theoretically $3.09 \mathrm{mmol}, 1$ equiv) and $\mathrm{N}$-[2(trimethylsilyl)ethoxycarbonyloxy]succinimide (Teoc-OSu, $1.20 \mathrm{mg}, 4.64 \mathrm{mmol}, 1.50$ equiv) in 1,4-dioxane $(7.73 \mathrm{~mL})$ was treated with triethylamine $(2.15 \mathrm{~mL}, 15.5 \mathrm{mmol}, 5.00$ equiv $)$ at $23{ }^{\circ} \mathrm{C}$, and the resulting solution was warmed to $40{ }^{\circ} \mathrm{C}$. After $12 \mathrm{~h}$ of stirring at this temperature, LCMS analysis showed full consumption of starting material, and the reaction mixture was diluted with ethyl acetate $(200 \mathrm{~mL})$. The resulting product solution was washed sequentially with saturated aqueous ammonium chloride solution $(2 \times 40 \mathrm{~mL})$ and saturated sodium chloride solution $(40 \mathrm{~mL})$. The washed solution was then dried over sodium sulfate, filtered, and concentrated to provide a foaming, gummy oil. This crude residue was purified by flash-column chromatography (120 g silica gel, eluting with hexanes initially, grading to $15 \%$ ethyl acetate-hexanes) to furnish the product (S19) as a crispy, white amorphous solid (1.61 g, 66\%, 2 steps).

$\mathrm{R}_{f}=0.48$ (20\% ethyl acetate-hexanes, $\left.\mathrm{UV}+\mathrm{KMnO}_{4}\right)$.

${ }^{1} \mathrm{H}$ NMR (500 MHz, $\left.\mathrm{CDCl}_{3}\right) \delta$ 7.83-7.80 (m, 4H), 7.71-7.67 (m, 4H), 7.51-7.38 (m, 8H), 4.96 $(\operatorname{app~t}, J=3.8 \mathrm{~Hz}, 1 \mathrm{H}), 4.87(\mathrm{dd}, J=5.6,2.3 \mathrm{~Hz}, 1 \mathrm{H}), 4.34(\mathrm{dd}, J=6.6,4.1 \mathrm{~Hz}, 1 \mathrm{H}), 4.27$ $(\mathrm{dd}, J=5.6,3.6 \mathrm{~Hz}), 4.26-4.14(\mathrm{~m}, 2 \mathrm{H}), 3.90(\mathrm{dd}, J=10.8,4.1 \mathrm{~Hz}, 1 \mathrm{H}), 3.73(\mathrm{dd}, J=10.8$ $6.6 \mathrm{~Hz}, 1 \mathrm{H}), 3.61(\mathrm{~d}, J=3.8 \mathrm{~Hz}, 1 \mathrm{H}), 2.42(\mathrm{~d}, J=2.2 \mathrm{~Hz}, 1 \mathrm{H}), 1.14(\mathrm{~s}, 9 \mathrm{H}), 1.10(\mathrm{~s}, 9 \mathrm{H})$, $1.02-0.98(\mathrm{~m}, 1 \mathrm{H}), 0.93-0.89(\mathrm{~m}, 1 \mathrm{H}), 0.06(\mathrm{~s}, 9 \mathrm{H})$. 
${ }^{13} \mathrm{C} \mathrm{NMR}\left(126 \mathrm{MHz}, \mathrm{CDCl}_{3}\right) \delta 157.1,136.3,136.1,135.7(2 \times \mathrm{C}), 133.0(2 \times \mathrm{C}), 132.3,131.9$, $130.3,130.2,130.0,129.9,128.0,127.9(2 \times C), 127.7,83.2,80.8,75.9,70.2,64.8,62.9$, 62.1, $26.9(2 \times C), 19.4(2 \times C), 17.7,-1.4$.

IR (neat, cm ${ }^{-1}$ ): 2954 (2), 2858 (w), 1702 (w), 1427 (m), 1104 (s), 837 (m), 731 (s), 699 (s). HRMS (ESI+, $m / z):[\mathrm{M}+\mathrm{H}]^{+}$calc'd for $\mathrm{C}_{45} \mathrm{H}_{59} \mathrm{NO}_{6} \mathrm{Si}_{3}, 794.3723$; found 794.3720. 

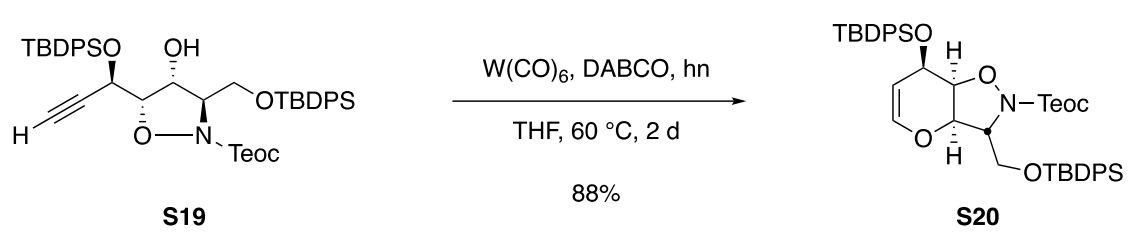

\section{Glycal S20.}

In a 100-mL borosilicate glass microwave reaction vial, alkynol S19 (1.60 g, $2.02 \mathrm{mmol}$, 1 equiv) was dried by azeotropic removal of benzene. To the dried starting material was added tungsten hexacarbonyl (177 mg, $0.504 \mathrm{mmol}, 0.250$ equiv; CAUTION: tungsten hexacarbonyl is a volatile source of metal and of carbon monoxide. Manipulations of this reagent should be conducted within a well-ventilated fume hood.) and 1,4-diazabicyclo[2.2.2] octane (452 mg, 4.03 mmol, 2.00 equiv). The vial was flushed with dry argon gas, and then anhydrous, degassed tetrahydrofuran $(20.2 \mathrm{~mL})$ was added at $23{ }^{\circ} \mathrm{C}$. The resulting colorless solution attained a vibrant fluorescent yellow color within 3 minutes. The vial was sealed and was transferred to a pre-heated oil bath $\left(60^{\circ} \mathrm{C}\right)$ positioned inside a photochemistry safety cabinet. The reaction mixture was heated with constant UV irradiation from an adjacent 200-Watt mercury-vapor bulb filtered through a water-cooled Pyrex glass jacket (CAUTION: exposure to high-intensity UV light can cause irreversible vision loss. Never open the safety cabinet when the UV lamp is on). Progress was monitored by TLC ( $20 \%$ ethyl acetate-hexanes, UV+KMnO 4$)$. After $2 \mathrm{~d}$, full consumption of alkynol substrate was achieved, and the crude product mixture was concentrated to dryness in vасио. The goldenrod-colored, oily residue was purified by flash-column chromatography (120 g silica gel, eluting with hexanes initially, grading to $15 \%$ ethyl acetate-hexanes) to provide glycal S20 as a viscous, colorless oil (1.40 g, 88\%). 
${ }^{1} \mathrm{H}$ NMR $\left(500 \mathrm{MHz}, \mathrm{C}_{6} \mathrm{D}_{6}\right) \delta$ 7.93-7.91 (m, 2H), 7.88-7.85 (m, 2H), 7.70-7.65 (m, 4H), 7.28-7.18 (m, 12H), $5.98(\mathrm{dd}, J=6.5,2.2 \mathrm{~Hz}, 1 \mathrm{H}), 4.69(\operatorname{app~dt}, J=6.5,1.9 \mathrm{~Hz}, 1 \mathrm{H}), 4.64(\mathrm{dd}, J=$ 7.0, 4.1 Hz, 1H), $4.61($ app dt, $J=4.4,2.1 \mathrm{~Hz}), 4.32-4.26(\mathrm{~m}, 2 \mathrm{H}), 4.24-4.17(\mathrm{~m}, 2 \mathrm{H}), 3.85$ (dd, $J=10.9,4.1 \mathrm{~Hz}, 1 \mathrm{H}), 3.69(\mathrm{dd}, J=10.8,7.0 \mathrm{~Hz}, 1 \mathrm{H}), 1.22(\mathrm{~s}, 9 \mathrm{H}), 1.10(\mathrm{~s}, 9 \mathrm{H}), 0.91$ (t, $J=8.3 \mathrm{~Hz}, 2 \mathrm{H}),-0.07(\mathrm{~s}, 9 \mathrm{H})$.

${ }^{13} \mathrm{C}$ NMR $\left(126 \mathrm{MHz}, \mathrm{C}_{6} \mathrm{D}_{6}\right) \delta$ 157.3, 142.0, $136.3(2 \times \mathrm{C}), 136.0(2 \times \mathrm{C}), 134.2(2 \times \mathrm{C}), 133.5$, 133.4, $130.2(4 \times C), 128.4,128.2(2 \times C), 128.1,102.1,78.9,76.9,69.3,64.5,63.6,63.3$, $27.1(2 \times C), 19.6,19.4,17.7,-1.4$.

IR (neat, $\mathrm{cm}^{-1}$ ): 2954 (m), 2931 (m), 2857 (m), 1702 (m), 1427 (m), 1111 (s), 1066 (s), 837 (m), $701(s)$.

HRMS (ESI+, $m / z)$ : $[\mathrm{M}+\mathrm{H}]^{+}$calc'd for $\mathrm{C}_{45} \mathrm{H}_{59} \mathrm{NO}_{6} \mathrm{Si}_{3}, 794.3723$; found 794.3696. 

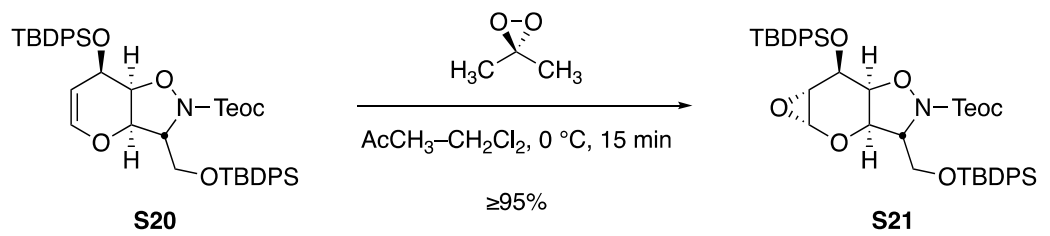

\section{Glycal epoxide S21.}

A solution of dimethyldioxirane in acetone was prepared, and its concentration was assayed according to the procedures of Murray and Singh. ${ }^{22}$ A solution of glycal S20 (920 mg, $1.16 \mathrm{mmol}$, 1 equiv) in dichloromethane $(11.6 \mu \mathrm{L})$ was cooled to $0{ }^{\circ} \mathrm{C}$, whereupon dimethyldioxirane solution $(0.0775 \mathrm{M}, 17.9 \mathrm{~mL}, 1.39 \mu \mathrm{mol}, 1.20$ equiv) was added dropwise over $3 \mathrm{~min}$. The reaction mixture was stirred at $0{ }^{\circ} \mathrm{C}$ for $15 \mathrm{~min}$, at which point TLC analysis $\left(\mathrm{NH}_{2}\right.$ silica gel, $20 \%$ ethyl acetatehexanes, UV+PAA) indicated full consumption of starting material. The mixture was then concentrated under a stream of dry argon, and the residue was dried by azeotropic removal of benzene to afford glycal epoxide $\mathbf{S 2 1}$ as a colorless oil that was suitable for use without further purification (quantitative yield, $\geq 95 \%$ purity by NMR).

$\mathrm{R}_{f}=0.63\left(\mathrm{NH}_{2}\right.$ silica gel, $20 \%$ ethyl acetate-hexanes $+2 \%$ methanol, $\left.\mathrm{UV}+\mathrm{CAM}\right)$.

${ }^{1} \mathrm{H}$ NMR (500 MHz, $\left.\mathrm{C}_{6} \mathrm{D}_{6}\right) \delta$ 7.89-7.86 (m, 2H), 7.80-7.76 (m, 2H), 7.65-7.59 (m, 4H), 7.22-7.13 (m, 12H), $4.65(\operatorname{app~dt}, J=2.3,1.1 \mathrm{~Hz}, 1 \mathrm{H}), 4.61(\mathrm{dd}, J=7.1,4.3 \mathrm{~Hz}, 1 \mathrm{H}), 4.31(\mathrm{~d}, J=5.1$ $\mathrm{Hz}, 1 \mathrm{H}), 4.28-4.17(\mathrm{~m}, 2 \mathrm{H}), 4.12(\mathrm{~d}, J=2.0,1 \mathrm{H}), 3.88(\mathrm{~d}, J=4.9 \mathrm{~Hz}, 1 \mathrm{H}), 3.74(\mathrm{dd}, J=$ $10.9,4.3 \mathrm{~Hz}, 1 \mathrm{H}), 3.53(\mathrm{dd}, J=10.8,7.2 \mathrm{~Hz}, 1 \mathrm{H}), 2.94($ app t, $J=1.1 \mathrm{~Hz}, 1 \mathrm{H}), 1.19(\mathrm{~s}$, 9H), 1.04 (s, 9H), $0.88(\mathrm{t}, J=8.3 \mathrm{~Hz}, 2 \mathrm{H}),-0.11(\mathrm{~s}, 9 \mathrm{H})$.

${ }^{13} \mathrm{C}$ NMR $\left(126 \mathrm{MHz}, \mathrm{C}_{6} \mathrm{D}_{6}\right) \delta 157.2,136.2,136.1,135.9(2 \times \mathrm{C}), 133.4(2 \times \mathrm{C}), 133.3,133.2$ $130.3(2 \times \mathrm{C}), 130.1,128.3,128.2,128.1,77.1,74.7,73.2,69.4,66.9,64.5,63.3,51.6$, 27.0, 19.6, 19.3, 17.6, -1.5 . Two phenyl carbons are not observed: one is believed to be 
obfuscated by the solvent signal, and the other is believed to coincide with another resonance $(\delta 130.1)$.

IR (neat, $\left.\mathrm{cm}^{-1}\right): 2954(\mathrm{~m}), 2931(\mathrm{~m}), 2858(\mathrm{~m}), 1703(\mathrm{~m}), 1427(\mathrm{~m}), 1249(\mathrm{~m}), 1111(\mathrm{~s}), 822(\mathrm{~s})$, $700(\mathrm{~s})$.

HRMS (ESI+, $m / z):[\mathrm{M}+\mathrm{H}]^{+}$calc'd for $\mathrm{C}_{45} \mathrm{H}_{59} \mathrm{NO}_{7} \mathrm{Si}_{3}, 810.3672$; found 810.3667. 


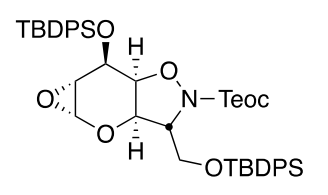

S21

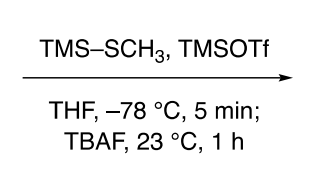

$>99 \%$

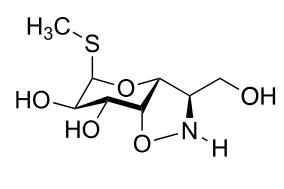

S22

\section{Isoxazolidine triol S22.}

In a 25-mL round-bottomed flask fitted with a magnetic stir bar, glycal epoxide $\mathbf{S 2 1}$ (321 $\mathrm{mg}, 396 \mathrm{mmol}, 1$ equiv) was dried by azeotropic removal of benzene. Once dried, the starting material was dissolved in tetrahydrofuran $(3.96 \mathrm{~mL})$, and the resulting solution was chilled to -78 ${ }^{\circ} \mathrm{C}$. Once cooled, (methylthio)trimethylsilane ( $169 \mu \mathrm{L}, 1.19 \mathrm{mmol}, 3.00$ equiv) was added; next, trimethylsilyl trifluoromethanesulfonate $(14.3 \mu \mathrm{L}, 79.0 \mu \mathrm{mol}, 0.200$ equiv) was added dropwise. After 5 min, TLC analysis ( $\mathrm{NH}_{2}$ silica gel, 2\% methanol-20\% ethyl acetate-hexanes, UV+CAM) showed complete conversion of starting material to a slightly more polar product. At this point the reaction was quenched with the addition of tetra- $n$-butylammonium fluoride solution (1.0 M in tetrahydrofuran, $2.8 \mathrm{~mL}, 2.8 \mathrm{mmol}, 7.0$ equiv), and the mixture was warmed to $23^{\circ} \mathrm{C}$. After $1 \mathrm{~h}$ of stirring at $23{ }^{\circ} \mathrm{C}$, LCMS analysis showed that global desilylation was complete. The mixture was loaded directly onto a column of silica gel ( $20 \mathrm{~g})$ that had been pre-equilibrated with ethyl acetate; the column was eluted first with ethyl acetate $(300 \mathrm{~mL})$, then with 5\% methanol-ethyl acetate (300 $\mathrm{mL})$, and finally with $10 \%$ methanol-ethyl acetate $(600 \mathrm{~mL})$. Fractions containing product were identified by TLC (10\% methanol-ethyl acetate, PAA), and these fractions were pooled and concentrated to afford isoxazolidine triol S22 (103 $\mathrm{mg}, 110 \%)$ that was sufficiently pure for use in the subsequent $N-O$ bond cleavage reaction.

For characterization purposes, a small quantity (ca. $20 \mathrm{mg}$ ) of this product was subjected to preparative HPLC (with a flow rate of $15 \mathrm{~mL} / \mathrm{min}$, eluting with $0.1 \%$ trifluoroacetic acid-1\% acetonitrile-water for $2 \mathrm{~min}$, then grading to $0.1 \%$ trifluoroacetic acid-20\% acetonitrile-water 
over $18 \mathrm{~min}$; monitored by UV absorbance at $210 \mathrm{~nm}$; product $\mathrm{R}_{t}=8.75 \mathrm{~min}$ ) to give the trifluoroacetic acid salt of $\mathbf{S 2 2} \cdot \mathrm{CF}_{3} \mathrm{CO}_{2} \mathrm{H}$ in pure form.

$\mathrm{R}_{f}=0.06$ (free base, $10 \%$ methanol-ethyl acetate, PAA).

${ }^{1} \mathrm{H}$ NMR (hydrotrifluoroacetate salt, $\left.500 \mathrm{MHz}, \mathrm{CD}_{3} \mathrm{OD}\right) \delta 5.27(\mathrm{~d}, J=5.0 \mathrm{~Hz}, 1 \mathrm{H}), 4.98(\mathrm{~d}, J=$ $2.0 \mathrm{~Hz}, 1 \mathrm{H}), 4.71(\mathrm{dd}, J=3.8,2.1 \mathrm{~Hz}, 1 \mathrm{H}), 4.12(\mathrm{dd}, J=10.1,5.1 \mathrm{~Hz}, 1 \mathrm{H}), 4.10(\operatorname{app} \mathrm{t}, J$ $=5.5 \mathrm{~Hz}, 1 \mathrm{H}), 3.99(\mathrm{dd}, J=10.0,3.8 \mathrm{~Hz}, 1 \mathrm{H}), 3.87(\mathrm{dd}, J=12.0,4.8 \mathrm{~Hz}, 1 \mathrm{H}), 3.83(\mathrm{dd}, J$ $=12.0,6.0 \mathrm{~Hz}, 1 \mathrm{H}), 2.14(\mathrm{~s}, 3 \mathrm{H})$.

${ }^{13} \mathrm{C}$ NMR (hydrotrifluoroacetate salt, $\left.100 \mathrm{MHz}, \mathrm{CD}_{3} \mathrm{OD}\right) \delta 89.0,85.4,76.1,70.1,69.0,68.6,59.0$, 13.1.

${ }^{19} \mathrm{~F}$ NMR (hydrotrifluoroacetate salt, $\left.471 \mathrm{MHz}, \mathrm{CD}_{3} \mathrm{OD}\right) \delta-77.3(\mathrm{~s}, 3 \mathrm{~F})$.

IR (hydrotrifluoroacetate salt, neat, $\mathrm{cm}^{-1}$ ): 3349 (br), 1672 (s), 1434 (w), 1199 (s), 1139 (m), 1095 (m), $1051(\mathrm{~m})$.

HRMS (ESI+, $m / z):[\mathrm{M}+\mathrm{H}]^{+}$calc'd for $\mathrm{C}_{8} \mathrm{H}_{15} \mathrm{NO}_{5} \mathrm{~S} 238.0744$; found 238.0739. 


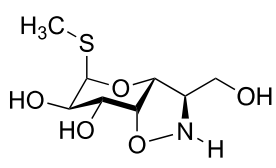

S22

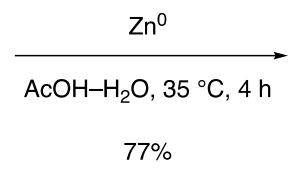

$77 \%$

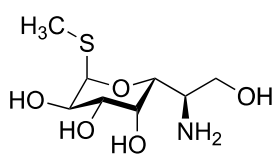

40

\section{Methylthio-8-norlincosamine (40).}

To a solution of isoxazolidine triol $\mathbf{S 2 2}(234 \mathrm{mg}, 986 \mu \mathrm{mol}, 1$ equiv) in 50\% v/v acetic acid-water $(9.86 \mathrm{~mL})$ was added activated zinc powder $(258 \mathrm{mg}, 3.94 \mathrm{mmol}, 4.00$ equiv). The mixture was heated to $35{ }^{\circ} \mathrm{C}$ with stirring, and after $4 \mathrm{~h}$, LCMS showed complete conversion of starting material to aminotetraol product. The mixture was cooled before it was filtered through a Celite pad. The filter cake was washed with methanol $(3 \times 5 \mathrm{~mL})$, and the combined filtrates were concentrated to dryness. Residual acetic acid was removed by repeated concentration from $50 \%$ v/v methanol-toluene. Once dried, the crude residue, containing the hydroacetate salt of the desired product as well as zinc acetate as a major impurity, was dissolved in methanol (20 mL) and was treated with Amberlyst A26 resin (hydroxide form, $4.00 \mathrm{~g}$ ). After stirring the mixture at $23{ }^{\circ} \mathrm{C}$ for $1 \mathrm{~h}$, the ion-exchange beads were removed by filtration, and the filtrate was concentrated to give a white solid. This crude residue was finally purified by flash-column chromatography (25 silica gel, eluting with $1 \%$ ammonium hydroxide-10\% methanol-dichloromethane initially, grading to $10 \%$ ammonium hydroxide- $40 \%$ methanol-dichloromethane) to provide methylthio-8norlincosamine (40) as a white solid (182 $\mathrm{mg}, 77 \%)$.

$\mathrm{R}_{f}=0.30$ (10\% ammonium hydroxide-40\% methanol-dichloromethane, ninhydrin). ${ }^{28}$

\footnotetext{
${ }^{28}$ Note: Prior to staining with ninhydrin, TLC plates must be heated thoroughly $\left(\sim 200{ }^{\circ} \mathrm{C}, 30 \mathrm{~s}\right)$ to drive off residual ammonia, which interferes with proper staining.
} 
${ }^{1} \mathrm{H}$ NMR $\left(400 \mathrm{MHz}, \mathrm{D}_{2} \mathrm{O}\right) \delta 5.17(\mathrm{~d}, J=5.7 \mathrm{~Hz}, 1 \mathrm{H}), 3.95-3.92(\mathrm{~m}, 2 \mathrm{H}), 3.84(\mathrm{~d}, J=9.2 \mathrm{~Hz}, 1 \mathrm{H})$, $3.63(\mathrm{dd}, J=11.0,2.5 \mathrm{~Hz}, 1 \mathrm{H}), 3.54(\mathrm{dd}, J=10.2,2.9 \mathrm{~Hz}, 1 \mathrm{H}), 3.38(\mathrm{dd}, J=11.2,6.1 \mathrm{~Hz}$, 1H), $2.91(\mathrm{ddd}, J=9.0,6.1,3.2 \mathrm{~Hz}, 1 \mathrm{H}), 1.92(\mathrm{~s}, 3 \mathrm{H})$.

${ }^{13} \mathrm{C}$ NMR (100 MHz, D2O) 87.0, 70.5, 70.3, 68.2, 67.8, 63.0, 50.6, 12.0.

FTIR (neat, cm ${ }^{-1}$ ): 2939 (s), 2865 (m), 1711 (s), 1464 (m), 1434 (m), 1125 (m), 1036 (m), 756 (s). HRMS (ESI+, $m / z)$ : $[\mathrm{M}+\mathrm{H}]^{+}$calc'd for $\mathrm{C}_{8} \mathrm{H}_{17} \mathrm{NO}_{5} \mathrm{~S}, 240.0900$; found 240.0899 . 

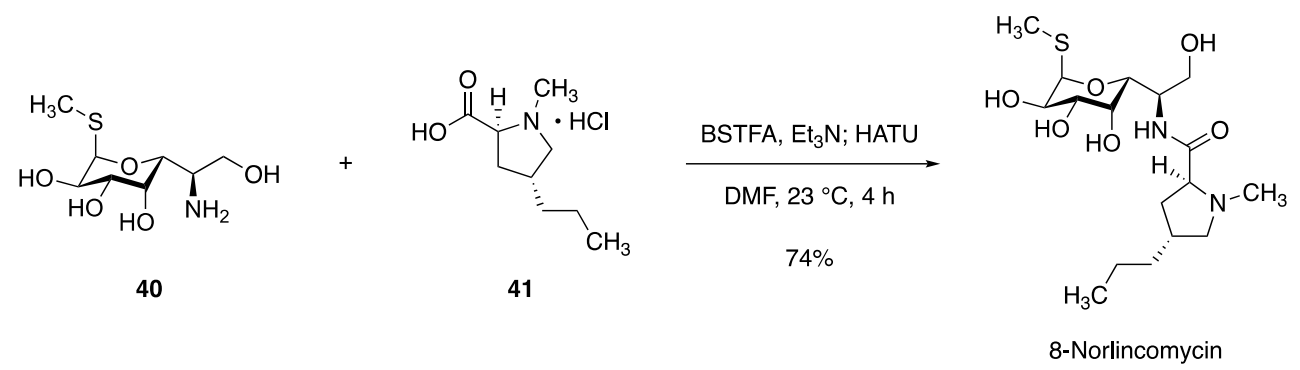

(42)

\section{8-Norlincomycin (3.5).}

In a 2-5-mL glass microwave vial fitted with a magnetic stir bar, methylthio-8norlincosamine (40,100 mg, $418 \mu \mathrm{mol}, 1$ equiv) was dissolved in $N, N$-dimethylformamide (2.09 mL). Triethylamine $(262 \mu \mathrm{L}, \quad 1.88 \quad$ mmol, $4.50 \quad$ equiv $)$ and $\quad N, O$ bis(trimethylsilyl)trifluoroacetamide $(224 \mu \mathrm{L}, 836 \mu \mathrm{mol}, 2.00$ equiv) were added next, and the solution was stirred at $23{ }^{\circ} \mathrm{C}$ for $1 \mathrm{~h}$ to ensure complete $O$-silylation. After this period, trans-4- $n$ propyl-L-hygric acid hydrochloride (41) (104 mg, $501 \mu \mathrm{mol}, 1.20$ equiv) and HATU (222 mg, 585 $\mu$ mol, 1.40 equiv) were added, causing the reaction mixture to attain a canary yellow hue. Following $4 \mathrm{~h}$ of stirring at $23^{\circ} \mathrm{C}$, LCMS analysis showed complete conversion of aminotetraol starting material and its (oligo)silylated congeners to amide products. The reaction mixture was consequently diluted with ethyl acetate $(25 \mathrm{~mL})$ and the diluted solution was washed with saturated aqueous sodium bicarbonate solution $(10 \mathrm{~mL})$. The aqueous layer was extracted with ethyl acetate $(3 \times 10 \mathrm{~mL})$, and the combined organic layers were then washed with saturated aqueous sodium chloride solution $(15 \mathrm{~mL})$. The washed organic solution was dried over sodium sulfate, filtered, and concentrated; and the residue thus obtained was re-dissolved in 50\% v/v methanol-acetic acid. This colorless solution was stirred at $40{ }^{\circ} \mathrm{C}$ for $24 \mathrm{~h}$ to ensure complete desilylation before it was concentrated to dryness in vacuo. Residual acetic acid was removed by repeated concentration of the mixture from 50\% v/v methanol-toluene. Once thoroughly dried, the crude residue was treated 
with methanol $(10 \mathrm{~mL})$ and Amberlyst A26 resin (hydroxide form, $2.00 \mathrm{~g}$ ). The resulting mixture was stirred at $23{ }^{\circ} \mathrm{C}$ for $1 \mathrm{~h}$ before the ion-exchange beads were removed by filtration and the filtrate was concentrated. This light amber-colored oily residue was purified by flash-column chromatography (18 g silica gel, eluting with $0.5 \%$ ammonium hydroxide-5\% methanoldichloromethane initially; grading to $1 \%$ ammonium hydroxide-10\% methanol-dichloromethane) to furnish 8-norlincomycin (42) as a light yellow, foaming solid (121 mg, 74\%).

$\mathrm{R}_{f}=0.23$ (1\% ammonium hydroxide-10\% methanol-dichloromethane, PMA or $\mathrm{I}_{2}$ ).

${ }^{1} \mathrm{H}$ NMR $\left(500 \mathrm{MHz}, \mathrm{CD}_{3} \mathrm{OD}\right) \delta 5.29(\mathrm{~d}, J=5.6 \mathrm{~Hz}, 1 \mathrm{H}), 4.17(\mathrm{~d}, J=8.9 \mathrm{~Hz}, 1 \mathrm{H}), 4.12-4.08(\mathrm{~m}$, 2H), $3.78(\operatorname{app~dt}, J=6.6,5.1 \mathrm{~Hz}, 2 \mathrm{H}), 3.72(\mathrm{dd}, J=10.7,4.2 \mathrm{~Hz}, 1 \mathrm{H}), 3.63(\mathrm{dd}, J=10.1$, $3.4 \mathrm{~Hz}, 1 \mathrm{H}), 3.21(\mathrm{dd}, J=8.7,6.0 \mathrm{~Hz}, 1 \mathrm{H}), 2.95(\mathrm{dd}, J=10.6,4.8 \mathrm{~Hz}, 1 \mathrm{H}), 2.37(\mathrm{~s}, 3 \mathrm{H})$, 2.19-2.15 (m, 1H), $2.08(\mathrm{~s}, 3 \mathrm{H}), 2.05$ (dd, $J=10.1,8.8 \mathrm{~Hz}, 1 \mathrm{H}), 1.99$ (ddd, $J=13.0,8.2$, $4.8 \mathrm{~Hz}, 1 \mathrm{H}), 1.84(\operatorname{app} \mathrm{dt}, J=12.9,10.3 \mathrm{~Hz}, 1 \mathrm{H}), 1.36-1.31(\mathrm{~m}, 4 \mathrm{H}), 0.92(\mathrm{t}, J=6.5 \mathrm{~Hz}$, $3 \mathrm{H})$.

${ }^{13} \mathrm{C}$ NMR (126 MHz, CD $\left.3 \mathrm{OD}\right) \delta 178.2,89.0,71.9,70.4,69.8(2 \times \mathrm{C}), 69.5,63.8,61.5,51.9,41.9$, 38.9, 38.6, 37.0, 22.6, 14.6, 12.8.

FTIR (neat, cm ${ }^{-1}$ ): 3333 (br), 2920 (s), 2787 (m), 1644 (s), 1525 (s), 1080 (s).

HRMS (ESI+, m/z): $[\mathrm{M}+\mathrm{H}]^{+}$calc'd for $\mathrm{C}_{17} \mathrm{H}_{32} \mathrm{~N}_{2} \mathrm{O}_{6} \mathrm{~S}, 393.2054$; found 393.2050. 


\section{Synthesis of Fully Synthetic Lincosamide Analogs 43-50}

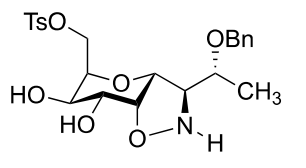

$\mathbf{S 1 3}$

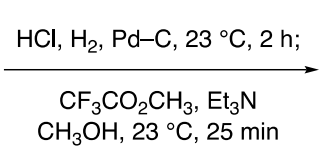

$>99 \%$

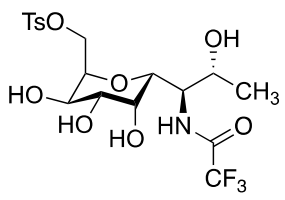

$\mathbf{S 2 3}$

\section{$N$-Trifluoroacetamido tetraol S23.}

A 50-mL round-bottomed flask was charged with isoxazolidine 13 (508 mg, $1.06 \mathrm{mmol}, 1$ equiv). Methanol $(10.6 \mathrm{~mL})$ was added, the resulting solution was chilled to $0{ }^{\circ} \mathrm{C}$, and the stirred solution was treated with hydrogen chloride $(1.06 \mathrm{~mL}, 4 \mathrm{M}$ solution in dioxane, $4.24 \mathrm{mmol}, 4.00$ equiv). The mixture was then concentrated in vacuo to remove methanol, dioxane, and excess hydrogen chloride; and the dried residue $(\mathbf{S 1 3} \bullet \mathrm{HCl})$ was re-dissolved in methanol $(10.6 \mathrm{~mL})$. To this solution was added $10 \% \mathrm{w} / \mathrm{w}$ palladium on carbon $(113 \mathrm{mg})$. The reaction flask was fitted with a 3-way stopcock to which a hydrogen-filled balloon had been affixed. The headspace in the flask was replaced with hydrogen gas by three evacuation-backfilling cycles, and the black reaction mixture was stirred at $23{ }^{\circ} \mathrm{C}$. After $2 \mathrm{~h}$, LCMS analysis indicated that isoxazolidine hydrogenolysis and $O$-debenzylation were complete. At this point, triethylamine $(738 \mu \mathrm{L}, 5.30$ mmol, 5.00 equiv) and methyl trifluoroacetate $(533 \mu \mathrm{L}, 5.30 \mathrm{mmol}, 5.00$ equiv) were added sequentially. After an additional 25 min, LCMS analysis demonstrated complete conversion of the primary amine intermediate to the corresponding trifluoroacetamide. The reaction mixture was filtered through a pad of Celite to remove catalyst, and the filtrate was concentrated to give product alongside triethylamine hydrochloride. In order to remove the latter, the crude residue was suspended in ethyl acetate $(30 \mathrm{~mL})$, and the organic solution was washed with saturated aqueous sodium chloride solution $(3 \times 10 \mathrm{~mL})$. The combined aqueous washes were extracted with ethyl 
acetate $(2 \times 10 \mathrm{~mL})$, and these extracts were washed with a fresh portion of saturated aqueous sodium chloride solution $(10 \mathrm{~mL})$. The combined organic layers were dried over sodium sulfate, the dried solution was filtered, and the filtrate was concentrated to give the product $(\mathbf{S 2 3})$ as a white solid (529 mg, 102\%). This material was sufficiently pure ( $\geq 90 \%$, based on ${ }^{1} \mathrm{H}$ NMR analysis) for use without further purification. An analytically pure sample ( $25 \mathrm{mg})$ was prepared by flash-column chromatography (4.5 g silica gel, eluting with $3 \%$ methanol-dichloromethane initially, grading to $10 \%$ methanol-dichloromethane).

$\mathrm{R}_{f}=0.27$ (10\% methanol-dichloromethane, UV+PMA).

${ }^{1} \mathrm{H}$ NMR $\left(600 \mathrm{MHz}, \mathrm{CD}_{3} \mathrm{OD}\right) \delta 7.81(\mathrm{~d}, J=8.4 \mathrm{~Hz}, 2 \mathrm{H}), 7.45(\mathrm{~d}, J=8.1 \mathrm{~Hz}, 2 \mathrm{H}), 4.41(\mathrm{dd}, J=$ $11.4,9.6 \mathrm{~Hz}, 1 \mathrm{H}), 4.28(\mathrm{dd}, J=11.4,2.8 \mathrm{~Hz}, 1 \mathrm{H}), 4.21(\mathrm{q}, J=7.1 \mathrm{~Hz}, 1 \mathrm{H}), 4.18(\mathrm{ddd}, J=$ 9.5, 7.0, $2.9 \mathrm{~Hz}, 1 \mathrm{H}), 3.98-3.95(\mathrm{~m}, 2 \mathrm{H}), 3.87(\mathrm{dd}, J=7.2,1.4 \mathrm{~Hz}, 1 \mathrm{H}), 3.48(\mathrm{dd}, J=10.1$, $3.2 \mathrm{~Hz}, 1 \mathrm{H}), 2.46(\mathrm{~s}, 3 \mathrm{H}), 1.15(\mathrm{~d}, J=6.4 \mathrm{~Hz}, 3 \mathrm{H})$.

${ }^{13} \mathrm{C}$ NMR (100 MHz, CD 3 OD) $\delta$ 146.6, 134.3, 131.2, 129.0, 76.1, 72.0, 70.9, 70.5, 68.2, 68.1, 66.6, 57.1, 21.6, 19.1. Trifluoroacetamide carbons were not resolved due to ${ }^{19} \mathrm{~F}$ nuclear coupling. ${ }^{19} \mathrm{~F}$ NMR $\left(376 \mathrm{MHz}, \mathrm{CD}_{3} \mathrm{OD}\right) \delta-77.44(\mathrm{~s}, 3 \mathrm{~F})$.

FTIR (neat, $\mathrm{cm}^{-1}$ ): 3381 (br), 2519 (br), 1710 (s), 1353 (m), 1175 (s), 1080 (m), 973 (m). HRMS (ESI+, $m / z)$ : $[\mathrm{M}+\mathrm{H}]^{+}$calc'd for $\mathrm{C}_{18} \mathrm{H}_{24} \mathrm{~F}_{3} \mathrm{NO}_{9} \mathrm{~S}, 488.1197$; found 488.1192 . 

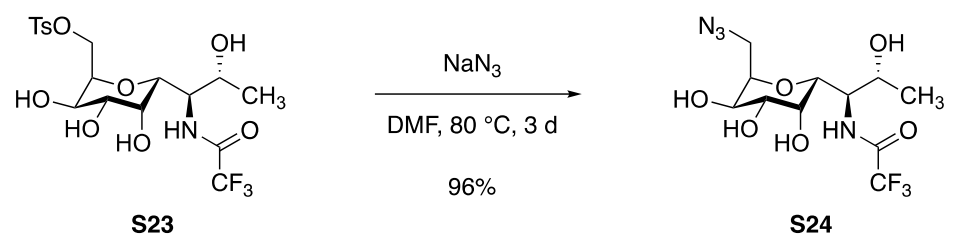

\section{Azidomethyl glycoside S24.}

An oven-dried 20-mL microwave vial was charged with a stir bar and $\mathbf{S 2 3}(400 \mathrm{mg}, 821$ $\mu$ mol, 1 equiv), and this material was dried by azeotropic removal of benzene. Sodium azide (533 $\mathrm{mg}, 8.21 \mathrm{mmol}, 10.0$ equiv) and anhydrous $N, N$-dimethylformamide $(4.10 \mathrm{~mL})$ were then added, and the vial was sealed. The mixture was heated to $80^{\circ} \mathrm{C}$ with rapid stirring. After 3 days, LCMS analysis indicated complete consumption of starting material; at this time the mixture was cooled, and the cooled reaction mixture was diluted with water $(5 \mathrm{~mL})$ and saturated aqueous sodium chloride solution $(35 \mathrm{~mL})$. This mixture was extracted with ethyl acetate $(4 \times 20 \mathrm{~mL})$. The combined organic extracts were dried over sodium sulfate, the dried product solution was filtered, and the filtrate was concentrated to give a light brown oil. In order to remove residual $N, N$ dimethylformamide, the crude residue was concentrated repeatedly from $10 \%$ methanol-toluene, affording S24 as a dull brown solid (281 $\mathrm{mg}, 96 \%)$. This material could be used in subsequent steps without further purification; an analytically pure sample $(\sim 20 \mathrm{mg})$ was prepared by flashcolumn chromatography (10 g silica gel, eluting with 5\% methanol-dichloromethane initially, grading to $10 \%$ methanol-dichloromethane), affording a brilliant white crystalline solid.

Melting point: $140-143^{\circ} \mathrm{C}$.

$\mathrm{R}_{f}=0.12$ (10\% methanol-dichloromethane, PMA). 
${ }^{1} \mathrm{H}$ NMR $\left(600 \mathrm{MHz}, \mathrm{CD}_{3} \mathrm{OD}\right) \delta 4.26(\operatorname{app~t}, J=6.9 \mathrm{~Hz}, 1 \mathrm{H}), 4.18(\mathrm{ddd}, J=10.1,6.5,3.1 \mathrm{~Hz}, 1 \mathrm{H})$, 4.05-3.97 (m, 4H), $3.71(\mathrm{dd}, J=13.8,10.5 \mathrm{~Hz}, 1 \mathrm{H}), 3.56(\mathrm{dd}, J=9.9,3.3 \mathrm{~Hz}, 1 \mathrm{H}), 3.45$ $(\mathrm{dd}, J=13.8,3.1 \mathrm{~Hz} 1 \mathrm{H}), 1.19(\mathrm{~d}, J=6.4 \mathrm{~Hz}, 3 \mathrm{H})$.

${ }^{13} \mathrm{C}$ NMR (100 MHz, CD $\left.3 \mathrm{OD}\right) \quad \delta$ 77.3, 71.8, 70.8,70.3, 68.6, 68.2, 57.5, 47.3, 19.4. Trifluoroacetamide carbons were not resolved due to ${ }^{19} \mathrm{~F}$ nuclear coupling.

${ }^{19} \mathrm{~F}$ NMR (471 MHz, CD $\left.3 \mathrm{OD}\right) \delta-77.56(\mathrm{~s}, 3 \mathrm{~F})$.

FTIR (neat, $\mathrm{cm}^{-1}$ ): 3319 (br), 2933 (w), 2105 (s), 1710 (s), 1556 (m), 1282 (m), 1214 (s), 1183 (s), 1159 (s), 1073 (s).

HRMS (ESI+, $m / z):[\mathrm{M}+\mathrm{H}]^{+}$calc'd for $\mathrm{C}_{11} \mathrm{H}_{17} \mathrm{~F}_{3} \mathrm{~N}_{4} \mathrm{O}_{6}, 359.1173$; found 359.1180 . 

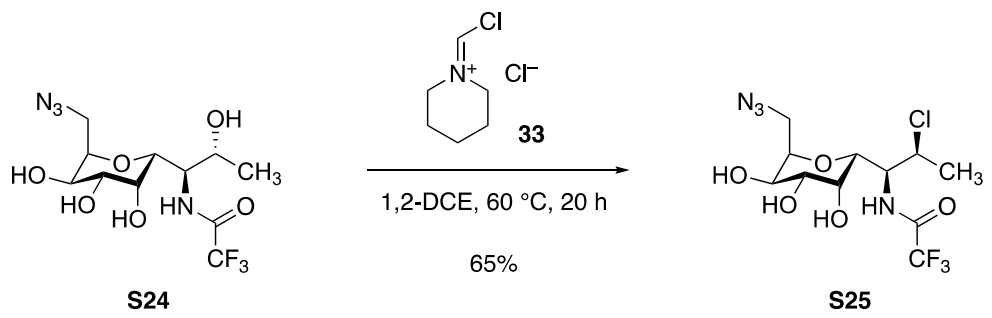

\section{Chloro compound S25.}

A flame-dried 20-mL microwave vial was charged with azidotetraol S24 (250 mg, 698 $\mu$ mol, 1 equiv), and this starting material was dried by azeotropic removal of benzene. The dried residue was suspended in 1,2-dichloroethane $(11.6 \mathrm{~mL})$, and the resulting suspension was cooled to $0{ }^{\circ} \mathrm{C}$. Chloromethylenepipiridinium chloride $(\mathbf{3 3}, 704 \mathrm{mg}, 4.19 \mathrm{mmol}, 6.00$ equiv) was added in one portion, and the mixture was stirred rapidly at $0{ }^{\circ} \mathrm{C}$. After $15 \mathrm{~min}$, the originally light yellow suspension had clarified, forming a yellow homogeneous solution. The reaction mixture was then heated to $60{ }^{\circ} \mathrm{C}$, and over the course of $2 \mathrm{~h}$ the solution attained an intense sunset orange color. After $20 \mathrm{~h}$, LCMS analysis indicated that deoxychlorination was complete (evidenced by the disappearance of starting material and its mono- and di-formylated congeners; ESI $-m / z=357$, 385 , and 413 , respectively). The reaction mixture was cooled to $23^{\circ} \mathrm{C}$, and the cooled solution was transferred by cannula to a rapidly stirred, ice-cold sodium hydroxide solution $(8.38 \mathrm{~mL}, 0.5$ M, 4.19 mmol, 6.00 equiv). In order to saponify the formyl esters formed upon workup, the biphasic mixture was treated with additional $0.5 \mathrm{M}$ sodium hydroxide solution until the aqueous phase achieved $\mathrm{pH}=11$; the mixture was then warmed to $23{ }^{\circ} \mathrm{C}$ with constant vigorous stirring, and additional sodium hydroxide solution was added periodically to maintain $\mathrm{pH}=11$. After $24 \mathrm{~h}$, deformylation was complete by LCMS analysis. The mixture was transferred to a separatory funnel, and the layers were separated. The aqueous phase was then treated with solid sodium chloride until saturation was achieved, and the resulting aqueous solution was extracted with 
dichloromethane $(5 \times 7 \mathrm{~mL})$. The combined organic layers were dried over sodium sulfate, the dried solution was filtered, and the filtrate was concentrated to give a brown oil. This residue was purified by flash-column chromatography (12 g silica, eluting with dichloromethane initially, grading to 8\% methanol-dichloromethane) to give $\mathbf{S 2 5}$ as a brilliant white solid (170 $\mathrm{mg}, 65 \%$ ).

$\mathrm{R}_{f}=0.23$ (10\% methanol-dichloromethane PMA).

${ }^{1} \mathrm{H}$ NMR $\left(600 \mathrm{MHz}, \mathrm{CD}_{3} \mathrm{OD}\right) \delta 4.64(\mathrm{qd}, J=6.8,1.9 \mathrm{~Hz}, 1 \mathrm{H}), 4.51(\mathrm{dd}, J=9.6,1.8 \mathrm{~Hz}, 1 \mathrm{H}), 4.15$ $(\mathrm{ddd}, J=9.6,6.5,3.1 \mathrm{~Hz}, 1 \mathrm{H}), 4.01(\mathrm{dd}, J=9.9,6.6 \mathrm{~Hz}, 1 \mathrm{H}), 3.97(\mathrm{dd}, J=9.5,1.4 \mathrm{~Hz}$, 1H), $3.82(\mathrm{dd}, J=3.3,1.3 \mathrm{~Hz}, 1 \mathrm{H}), 3.66(\mathrm{dd}, J=13.8,9.4 \mathrm{~Hz}, 1 \mathrm{H}), 3.60(\mathrm{dd}, J=13.8,3.2$ $\mathrm{Hz}, 1 \mathrm{H}), 3.53(\mathrm{dd}, J=9.9,3.2 \mathrm{~Hz}, 1 \mathrm{H}), 1.44(\mathrm{~d}, J=6.8 \mathrm{~Hz}, 3 \mathrm{H})$.

${ }^{13} \mathrm{C}$ NMR (126 MHz, CD 3 OD) $\delta 159.3$ (q, $\left.J=37.4 \mathrm{~Hz}\right), 117.5(\mathrm{q}, J=286.8 \mathrm{~Hz}), 77.1,72.2,71.3$, $69.5,68.6,58.8,55.1,47.5,22.8$.

FTIR (neat, $\mathrm{cm}^{-1}$ ): 3384 (br), 2106 (s), 1716 (s), 1545 (m), 1289 (m), 1217 (s), 1176 (s), 1165 (s), $1078(\mathrm{~s})$.

HRMS (ESI-, m/z): [M-H] $]^{-}$calc'd for $\mathrm{C}_{11} \mathrm{H}_{16} \mathrm{ClF}_{3} \mathrm{~N}_{4} \mathrm{O}_{5}, 375.0689$; found 375.0692. 

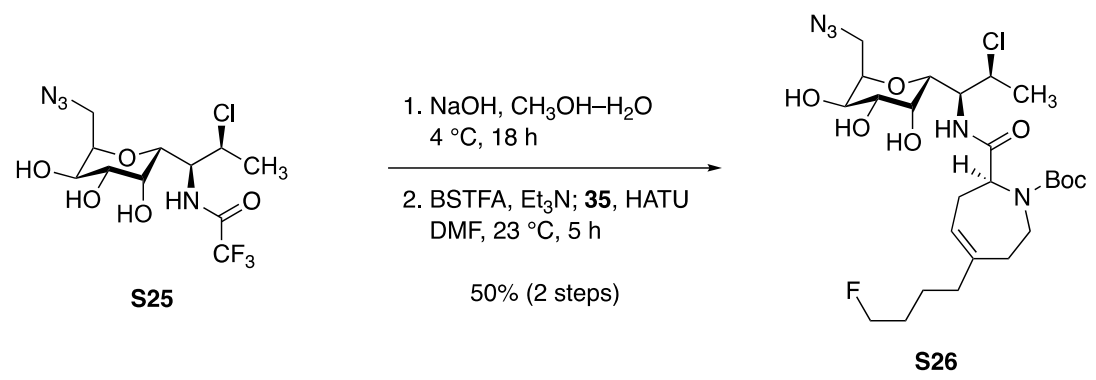

\section{Protected lincosamide S26.}

In a $10-\mathrm{mL}$ round-bottomed flask, trifluoroacetamide $\mathbf{S 2 5}$ (170 mg, $451 \mu \mathrm{mol}, 1$ equiv) was dissolved in a minimal quantity of methanol $(500 \mu \mathrm{L})$. This solution was chilled to $0{ }^{\circ} \mathrm{C}$ before it was treated with ice-cold aqueous sodium hydroxide solution $(1.00 \mathrm{M}, 2.26 \mathrm{~mL}, 2.26 \mathrm{mmol}, 5.0$ equiv). The mixture was stirred at $4{ }^{\circ} \mathrm{C}$ for $18 \mathrm{~h}$, at which point LCMS analysis showed that no starting material remained. The mixture was acidified with the addition of aqueous hydrogen chloride solution $(1.0 \mathrm{M})$, until the $\mathrm{pH}<2$ was attained. The acidified mixture was then concentrated to dryness to give a light-yellow residue comprising deacylated product, sodium chloride, and sodium trifluoroacetate. This mixture was suspended in ethanol (190 proof, $5 \mathrm{~mL}$ ), and the suspension was filtered. The solids were rinsed with fresh ethanol (190 proof, $2 \times 2 \mathrm{~mL}$ ), and the combined filtrates were concentrated. This residue was then re-dissolved in methanol (10 $\mathrm{mL}$ ), the solution was cooled to $0{ }^{\circ} \mathrm{C}$, and the mixture was treated with Amberlyst A26 resin (hydroxide form, $2.0 \mathrm{~g}$ ). After stirring for $1 \mathrm{~h}$ at $0{ }^{\circ} \mathrm{C}$, the ion-exchange beads were removed by filtration, and the filtrate was concentrated to provide aminotriol intermediate (132 mg, 104\%).

A portion of this crude aminotriol $(100 \mathrm{mg}, 360 \mu \mathrm{mol}, 1$ equiv) transferred to a $2-5-\mathrm{mL}$ glass microwave vial containing a magnetic stir bar, where it was dissolved in $N, N-$ dimethylformamide $(1.78 \mathrm{~mL})$. This solution was chilled to $0{ }^{\circ} \mathrm{C}$, triethylamine $(169 \mu \mathrm{L}, 1.21$ mmol, 3.40 equiv) and $N, O$-bis(trimethylsilyl)trifluoroacetamide $(143 \mu \mathrm{L}, 534 \mu$ mol, 1.50 equiv) 
were added, and the mixture was warmed immediately back to $23{ }^{\circ} \mathrm{C}$. After $1 \mathrm{~h}$ of stirring at this temperature, the mixture was transferred via cannula to a separate 4-mL glass vial (fitted with a magnetic stir bar and silicone septum screw cap) containing azepine acid 35 (135 mg, 427 mmol, 1.20 equiv). ${ }^{4}$ The mixture was then treated with HATU (176 mg, $463 \mu \mathrm{mol}, 1.30$ equiv), causing the dull brown solution to turn the color of chartreuse. After $5 \mathrm{~h}$, the mixture was diluted with ethyl acetate $(40 \mathrm{~mL})$, and the diluted solution was washed sequentially with $10 \% \mathrm{w} / \mathrm{v}$ aqueous citric acid solution $(2 \times 10 \mathrm{~mL})$, saturated aqueous sodium bicarbonate solution $(2 \times 10 \mathrm{~mL})$, and saturated aqueous sodium chloride solution $(10 \mathrm{~mL})$. The product solution was then dried over sodium sulfate, filtered, and concentrated; the residue obtained was re-dissolved in $50 \% \mathrm{v} / \mathrm{v}$ acetic acid-methanol $(8 \mathrm{~mL})$, and the resulting solution was stirred at $40{ }^{\circ} \mathrm{C}$ overnight in order to effect global desilylation. The mixture was then diluted with toluene $(10 \mathrm{~mL})$ and the diluted solution was concentrated. The dried residue was purified by flash-column chromatography ( $24 \mathrm{~g}$ silica gel, eluting with dichloromethane initially, grading to $10 \%$ methanol-dichloromethane) to provide S26 as white solid (98.2 mg, 50\%, 2 steps).

$\mathrm{R}_{f}=0.16$ (10\% methanol-dichloromethane, PMA)

${ }^{1} \mathrm{H}$ NMR $\left(600 \mathrm{MHz}, \mathrm{CD}_{3} \mathrm{OD}\right) \delta 5.53-5.48(\mathrm{~m}, 1 \mathrm{H}), 4.70-4.63(\mathrm{~m}, 1 \mathrm{H}), 4.53(\mathrm{dd}, J=12.0,4.1 \mathrm{~Hz}$, $1 \mathrm{H}), 4.41(\mathrm{dt}, J=47.5,5.9 \mathrm{~Hz}, 2 \mathrm{H}), 4.30(\mathrm{~d}, J=9.5 \mathrm{~Hz}, 1 \mathrm{H}), 4.14(\mathrm{ddd}, J=9.6,6.7,3.2$ $\mathrm{Hz}, 1 \mathrm{H}), 4.03-3.98(\mathrm{~m}, 1 \mathrm{H}), 3.90-3.85(\mathrm{~m}, 1 \mathrm{H}), 3.83(\mathrm{dd}, J=4.8,3.8 \mathrm{~Hz}, 1 \mathrm{H}), 3.80-3.73$ $(\mathrm{m}, 2 \mathrm{H}), 3.67-3.57(\mathrm{~m}, 2 \mathrm{H}), 3.54(\mathrm{dd}, J=10.0,3.2 \mathrm{~Hz}, 1 \mathrm{H}), 2.83-2.74(\mathrm{~m}, 1 \mathrm{H}), 2.51-2.38$ $(\mathrm{m}, 2 \mathrm{H}), 2.34-2.30(\mathrm{~d}, J=17.8 \mathrm{~Hz}, 1 \mathrm{H}), 2.01(\operatorname{app~t}, J=7.6 \mathrm{~Hz}, 2 \mathrm{H}), 1.69-1.58(\mathrm{~m}, 2 \mathrm{H})$, $1.54-1.44(\mathrm{~m}, 14 \mathrm{H})$. 
${ }^{13} \mathrm{C}$ NMR $\left(126 \mathrm{MHz}, \mathrm{CD}_{3} \mathrm{OD}\right) \delta 175.9,157.8,142.8,120.2,111.4,84.7(\mathrm{~d}, J=163.8 \mathrm{~Hz}), 81.9$, 77.2, 72.5, 72.1, 69.6, 68.9, 62.9, 59.4, 54.4, 47.7, 41.8, 39.5, 35.4, 31.0 (d, $J=19.8 \mathrm{~Hz})$, 28.8, $24.8(\mathrm{~d}, J=4.3 \mathrm{~Hz}), 22.8$.

FTIR (neat, $\mathrm{cm}^{-1}$ ): 3395 (br), 2972 (m), 2935 (m), 2101 (s), 1663 (s), 1445 (m), 1413 (m), 1393 (m), $1368(\mathrm{~m}), 1253(\mathrm{~m}), 1163(\mathrm{~s}), 1084(\mathrm{~m})$.

HRMS (ESI+, $m / z):[\mathrm{M}+\mathrm{H}]^{+}$calc'd for $\mathrm{C}_{25} \mathrm{H}_{41} \mathrm{ClFN}_{5} \mathrm{O}_{7}, 578.2751$; found 578.2738. 

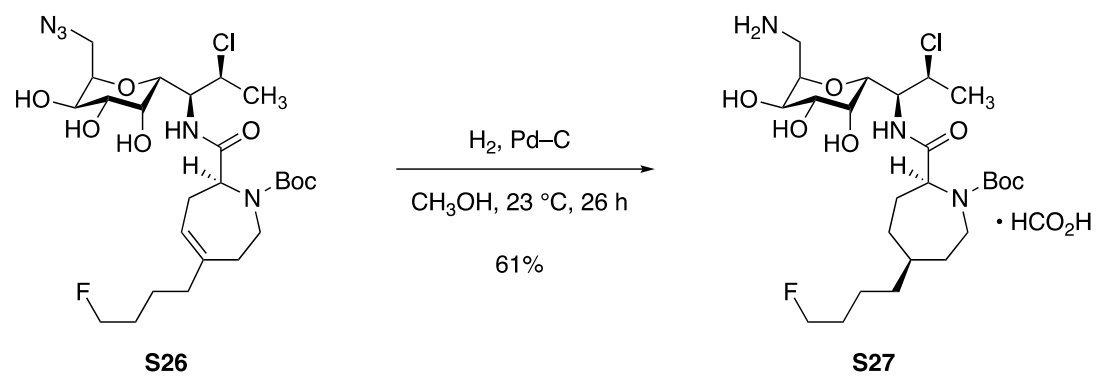

\section{Aminomethyl protected lincosamide S27.}

To a 1-dram vial containing azidotriol S26 (40.0 mg, $69.0 \mu \mathrm{mol}, 1$ equiv) was added methanol $(690 \mu \mathrm{L})$ and palladium on carbon $(10 \% \mathrm{w} / \mathrm{w}, 4.0 \mathrm{mg})$. The vial was fitted with a rubber septum and the headspace above the reaction mixture was flushed with hydrogen gas. The black heterogeneous reaction mixture was stirred at $23{ }^{\circ} \mathrm{C}$ under an atmosphere of hydrogen gas supplied by a balloon. After $26 \mathrm{~h}$, complete consumption of starting material was noted by LCMS analysis, and the reaction mixture was filtered through a pad of Celite $(1 \times 1 \mathrm{~cm})$ to remove catalyst. The filter pad was rinsed with methanol $(3 \times 2 \mathrm{~mL})$, and the filtrate was concentrated to give a colorless oil. The residue was purified by preparative HPLC on a Waters SunFire Prep $\mathrm{C}_{18}$ column $(5 \mu \mathrm{m}$, $250 \times 19 \mathrm{~mm}$; eluting with $0.1 \%$ formic acid $-5 \%$ acetonitrile-water initially, grading to $0.1 \%$ formic acid-25\% acetonitrile-water over $10 \mathrm{~min}$, then grading to $0.1 \%$ formic acid-55\% acetonitrile-water over the next $30 \mathrm{~min}$, with a flow rate of $15 \mathrm{~mL} / \mathrm{min}$; monitored by UV absorbance at $210 \mathrm{~nm})$ to provide $\mathbf{S 2 7}$ as a brilliant white solid (25.4 $\mathrm{mg}, 61 \%)$.

${ }^{1} \mathrm{H}$ NMR $(65: 35$ mixture of rotamers, asterisk [*] denotes minor rotamer peaks that could be resolved, $\left.500 \mathrm{MHz}, \mathrm{CD}_{3} \mathrm{OD}\right) \delta 8.49(\mathrm{br}, 1 \mathrm{H}), 4.73(\mathrm{q}, J=6.5 \mathrm{~Hz}, 1 \mathrm{H}), 4.51(\mathrm{dd}, J=12.6$, $5.8 \mathrm{~Hz}, 1 \mathrm{H}), * 4.47-4.35(\mathrm{~m}, 4 \mathrm{H}) .4 .22(\mathrm{app} \mathrm{dq}, J=6.1,4.2 \mathrm{~Hz}, 1 \mathrm{H}), 4.08(\mathrm{dd}, J=9.4,6.4$ $\mathrm{Hz}, 1 \mathrm{H}), * 4.05(\mathrm{dd}, J=9.5,6.3 \mathrm{~Hz}, 1 \mathrm{H}), 3.97-3.86(\mathrm{~m}, 2 \mathrm{H}), 3.68(\mathrm{~d}, J=9.5 \mathrm{~Hz}, 1 \mathrm{H}), 3.66$ 
$(\mathrm{d}, J=9.7 \mathrm{~Hz}, 1 \mathrm{H}), * 3.54(\mathrm{dd}, J=9.5,3.2 \mathrm{~Hz}, 1 \mathrm{H}), 3.36(\mathrm{app} \mathrm{dt}, J=13.5,4.1 \mathrm{~Hz}, 1 \mathrm{H})$, $3.21(\mathrm{ddd}, J=13.3,9.0,3.1 \mathrm{~Hz}, 1 \mathrm{H}), 3.11(\mathrm{dd}, J=15.1,11.7 \mathrm{~Hz}, 1 \mathrm{H}), 3.05(\mathrm{dd}, J=14.7$, $12.0 \mathrm{~Hz}, 1 \mathrm{H}),{ }^{*} 2.37-2.25(\mathrm{~m}, 1 \mathrm{H}), 1.99-1.95(\mathrm{~m}, 1 \mathrm{H}), 1.88-1.60(\mathrm{~m}, 4 \mathrm{H}), 1.48(\mathrm{~s}, 9 \mathrm{H})$, $1.46-1.37(\mathrm{~m}, 3 \mathrm{H}), 1.31-1.26(\mathrm{~m}, 2 \mathrm{H}), 1.21-1.07(\mathrm{~m}, 2 \mathrm{H})$.

FTIR (neat, cm ${ }^{-1}$ ): 3269 (br), 2967 (m), 2929 (m), 1655 (s), 1586 (s), 1406 (m), 1395 (m), 1367 (m), $1347(\mathrm{~m}), 1248(\mathrm{~m}), 1161(\mathrm{~s}), 1082(\mathrm{~m}), 776(\mathrm{w})$.

HRMS (ESI+, $m / z$ ): $[\mathrm{M}+\mathrm{H}]^{+}$calc'd for $\mathrm{C}_{25} \mathrm{H}_{45} \mathrm{ClFN}_{3} \mathrm{O}_{7}, 554.3003$; found 554.3005. 


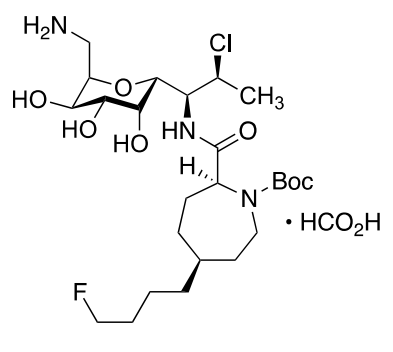

S27

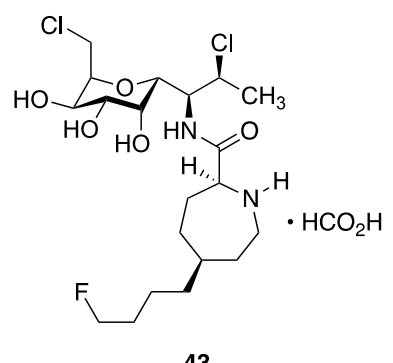

43

\section{Synthetic lincosamide 43.}

A nitrosyl chloride solution (1.08 M) was prepared according to the method described by Weiß and Wagner: ${ }^{29}$ A solution of isoamyl nitrite $(501 \mu \mathrm{L}, 3.73 \mathrm{mmol})$ in tetrahydrofuran $(2.50$ $\mathrm{mL}$ ) was cooled to $0{ }^{\circ} \mathrm{C}$ and was treated with chlorotrimethylsilane (475 $\left.\mu \mathrm{L}, 3.73 \mathrm{mmol}\right)$. The resulting solution was stirred at $0{ }^{\circ} \mathrm{C}$ for $1.5 \mathrm{~h}$ prior to use.

In a 1-mL vial, aminotriol $\mathbf{S 2 7}(5.0 \mathrm{mg}, 9.0 \mu \mathrm{mol})$ was dried by azeotropic removal of benzene. The dried starting material was then dissolved in tetrahydrofuran $(100 \mu \mathrm{L})$, and the resulting solution was cooled to $0{ }^{\circ} \mathrm{C}$ with stirring. Nitrosyl chloride solution $(1.08 \mathrm{M}, 100 \mu \mathrm{L}$, $108 \mu \mathrm{mol}, 12.0$ equiv) was then added, and the resulting solution was stirred at $0{ }^{\circ} \mathrm{C}$. After $2.5 \mathrm{~h}$, LCMS analysis indicated no starting material remained; the reaction mixture was concentrated under a stream of nitrogen. The dried residue was re-dissolved in 33\% trifluoroacetic aciddichloromethane, and the resulting solution was stirred at $23^{\circ} \mathrm{C}$ for $30 \mathrm{~min}$, at which point LCMS analysis indicated that Boc removal was complete. Toluene $(1 \mathrm{~mL})$ was added, and the resulting mixture was concentrated to dryness. The residue was purified by preparative HPLC on a Waters SunFire Prep $\mathrm{C}_{18}$ column $(5 \mu \mathrm{m}, 250 \times 19 \mathrm{~mm}$; eluting with $1 \%$ formic acid-5\% acetonitrile-water initially, grading to $0.1 \%$ formic acid-50\% acetonitrile-water over $40 \mathrm{~min}$, with a flow rate of 15

\footnotetext{
${ }^{29}$ Weiß, R.; Wagner, K.-G. Chem. Ber. 1984, 117, 1973-1976.
} 
$\mathrm{mL} / \mathrm{min}$; monitored by $\mathrm{UV}$ absorbance at $210 \mathrm{~nm}$ ) to afford $\mathbf{4 3} \cdot \mathrm{HCO}_{2} \mathrm{H}$ as a white solid (2.2 $\mathrm{mg}$, $52 \%)$

${ }^{1} \mathrm{H}$ NMR (600 MHz, CD $\left.3 \mathrm{OD}\right) \delta 4.69(\mathrm{q}, J=7.0 \mathrm{~Hz}, 1 \mathrm{H}), 4.43(\mathrm{dt}, J=47.5,6.0 \mathrm{~Hz}, 2 \mathrm{H}), 4.40(\mathrm{~m}$, $1 \mathrm{H}), 4.17(\operatorname{app~dt}, J=8.9,5.8 \mathrm{~Hz}, 1 \mathrm{H}), 4.03(\mathrm{dd}, J=10.0,6.5 \mathrm{~Hz}, 1 \mathrm{H}), 4.00(\mathrm{dd}, J=10.1$, $2.6 \mathrm{~Hz}, 1 \mathrm{H}), 3.85(\mathrm{~m}, 2.0 \mathrm{H}), 3.81(\mathrm{~d}, J=3.2 \mathrm{~Hz}, 1 \mathrm{H}), 3.76(\mathrm{~d}, J=9.7 \mathrm{~Hz}, 1 \mathrm{H}), 3.54(\mathrm{~d}, J$ $=10.0,3.2 \mathrm{~Hz}, 1 \mathrm{H}), 3.36(\mathrm{ddd}, J=14.0,6.2,3.1 \mathrm{~Hz}, 1 \mathrm{H}), 2.32(\mathrm{~m}, 1 \mathrm{H}), 2.04(\mathrm{~m}, 2 \mathrm{H}), 1.93$ $(\mathrm{m}, 1 \mathrm{H}), 1.73-1.52(\mathrm{~m}, 4 \mathrm{H}), 1.49-1.45(\mathrm{~m}, 2 \mathrm{H}), 1.44(\mathrm{~d}, J=6.9 \mathrm{~Hz}, 3 \mathrm{H}), 1.42-1.36(\mathrm{~m}$, $3 \mathrm{H})$. One methylene proton corresponding to the $\zeta$ position of the azepane is obfuscated by $\mathrm{CHD}_{2} \mathrm{OD}$ signal.

HRMS (ESI+, m/z): $[\mathrm{M}+\mathrm{H}]^{+}$calc'd for $\mathrm{C}_{20} \mathrm{H}_{35} \mathrm{Cl}_{2} \mathrm{FN}_{2} \mathrm{O}$, 473.1980 ; found 473.1983 . 

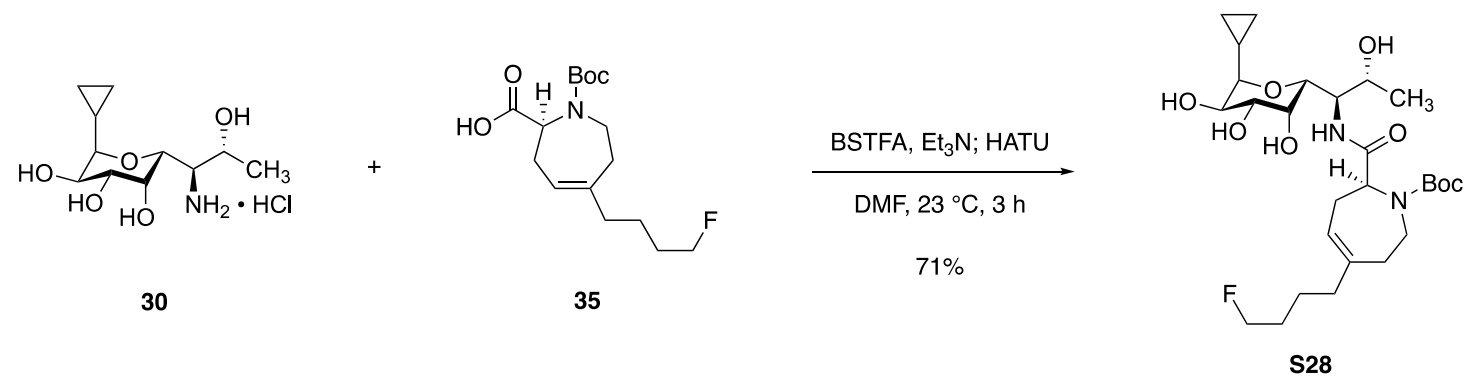

Protected lincosamide S28.

In a 4-mL glass vial fitted with a magnetic stir bar and silicone septum screw cap, an icecold solution of aminotetraol hydrochloride salt $\mathbf{3 0} \cdot \mathrm{HCl}(32 \mathrm{mg}, 0.11 \mathrm{mmol})$ and triethylamine (66 $\mu \mathrm{L}, 0.47 \mathrm{mmol}, 4.2$ equiv) in $N, N$-dimethylformamide $(564 \mu \mathrm{L})$ was treated with $N, O$ bis(trimethylsilyl)trifluoroacetamide $(61 \mu \mathrm{L}, 0.23 \mathrm{mmol}, 2.0$ equiv). The mixture was warmed to $23{ }^{\circ} \mathrm{C}$ and was stirred at that temperature for $1 \mathrm{~h}$ to ensure complete $O$-silylation before it was transferred via cannula to a separate 4-mL glass vial (fitted with a magnetic stir bar and silicone septum screw cap) containing azepine acid 35 (39 mg, $0.12 \mathrm{mmol}, 1.1$ equiv). ${ }^{4}$ The resulting mixture was then treated with HATU (56 $\mathrm{mg}, 0.15 \mathrm{mmol}, 1.3$ equiv), and the yellow solution was stirred at $23{ }^{\circ} \mathrm{C}$. After $3 \mathrm{~h}$, this solution was diluted with ethyl acetate $(20 \mathrm{~mL})$, and the organic solution was washed sequentially with $10-\mathrm{mL}$ portions of $10 \% \mathrm{w} / \mathrm{v}$ aqueous citric acid solution, saturated aqueous sodium bicarbonate solution, and saturated aqueous sodium chloride solution. The washed organic product solution was then dried over sodium sulfate, filtered, and concentrated to give a residue that was re-dissolved in $50 \% \mathrm{v} / \mathrm{v}$ acetic acid-methanol $(4 \mathrm{~mL})$. This solution was stirred at $40{ }^{\circ} \mathrm{C}$ overnight to effect global desilylation, the desilylated mixture was diluted with toluene $(4 \mathrm{~mL})$, and the diluted mixture was concentrated to dryness in vacuo. The residue thus obtained was purified by flash-column chromatography $(12 \mathrm{~g}$ silica gel, eluting with dichloromethane initially, grading to $10 \%$ methanol-dichloromethane) to provide $\mathbf{S 2 8}$ as a white solid (44 mg, 71\%). 
${ }^{1} \mathrm{H}$ NMR (60:40 mixture of rotamers, asterisk [*] denotes minor rotamer signals that could be resolved, $\left.600 \mathrm{MHz}, \mathrm{CD}_{3} \mathrm{OD}\right) \delta 7.97(\mathrm{~d}, J=8.9 \mathrm{~Hz}, 1 \mathrm{H}),{ }^{*} 7.83(\mathrm{~d}, J=9.3 \mathrm{~Hz}, 1 \mathrm{H}), 5.50-$ $5.46(\mathrm{~m}, 1 \mathrm{H}), 4.48(\mathrm{dd}, J=12.3,4.5 \mathrm{~Hz}, 1 \mathrm{H}), 4.40($ app dq, $J=47.5,6.3 \mathrm{~Hz}, 2 \mathrm{H}), 4.12-$ $4.07(\mathrm{~m}, 1 \mathrm{H}), 4.07-4.02(\mathrm{~m}, 1 \mathrm{H}), 4.01-4.91(\mathrm{~m}, 3 \mathrm{H}), 3.88(\mathrm{~d}, J=8.1 \mathrm{~Hz}, 1 \mathrm{H}), 3.86-3.80$ (m, 1H), 3.78-3.74 (m, 1H), 3.71-3.64 (m, 1H), 3.07 (dd, $J=9.8,6.8 \mathrm{~Hz}, 1 \mathrm{H}), 2.74$ (app q, $J=15.5 \mathrm{~Hz}, 1 \mathrm{H}), 2.49-2.37$ (m, 2H), 2.32 (br s, 1H), 2.29 (br s, 1H), * 1.99 (app q, $J=$ $7.2 \mathrm{~Hz}, 1 \mathrm{H}), 1.67-1.57(\mathrm{~m}, 2 \mathrm{H}), 1.52-1.48(\mathrm{~m}, 2 \mathrm{H}), 1.48(\mathrm{~s}, 9 \mathrm{H}), 1.45(\mathrm{~s}, 9 \mathrm{H}),{ }^{*} 1.22(\mathrm{~d}, J$ $=6.3 \mathrm{~Hz}, 3 \mathrm{H}), 1.19(\mathrm{~d}, J=6.4 \mathrm{~Hz}, 3 \mathrm{H}),{ }^{*} 1.15-1.09(\mathrm{~m}, 1 \mathrm{H}), 0.74(\mathrm{tdd}, J=8.5,6.0,4.4 \mathrm{~Hz}$, $1 \mathrm{H}), 0.50(\mathrm{tq}, J=9.2,4.9 \mathrm{~Hz}, 1 \mathrm{H}), 0.37(\mathrm{dq}, J=9.8,4.9 \mathrm{~Hz}, 1 \mathrm{H}), 0.27(\mathrm{dq}, J=10.0,5.1$ $\mathrm{Hz}, 1 \mathrm{H})$. 

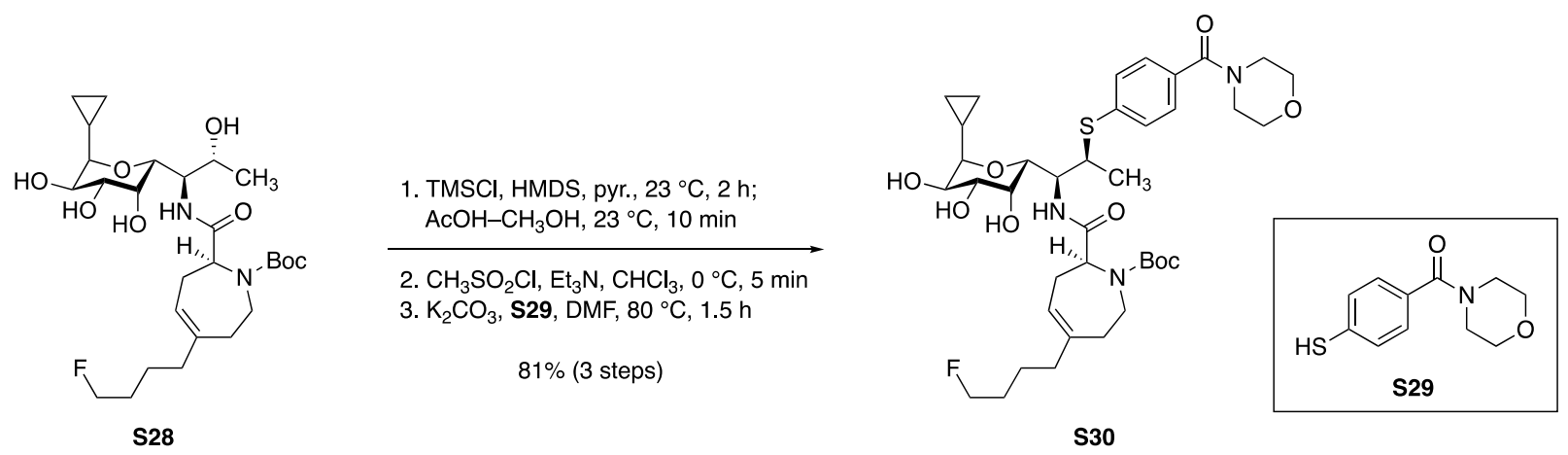

\section{Protected lincosamide S30.}

In a 1-mL glass vial fitted with a magnetic stir bar, an ice-cold solution of tetraol S28 (20.3 $\mathrm{mg}, 37.3 \mu \mathrm{mol}, 1$ equiv) in pyridine $(62.1 \mu \mathrm{L})$ was treated sequentially with hexamethyldisilazane (44.8 $\mu \mathrm{L}, 214 \mu \mathrm{mol}, 5.74$ equiv) and chlorotrimethylsilane (12.1 $\mu \mathrm{L}, 94.3 \mu \mathrm{mol}, 2.53$ equiv). The cooling bath was then removed, and the milky white suspension was stirred at $23{ }^{\circ} \mathrm{C}$ for $2 \mathrm{~h}$ before it was concentrated to dryness. The dried residue was partitioned between water (10 mL) and 50\% v/v ethyl acetate-hexanes $(10 \mathrm{~mL})$; the biphasic mixture was shaken vigorously until the layers were clear, and then the layers were separated. The organic layer was washed with a fresh portion of water $(5 \mathrm{~mL})$. The washed organic solution was dried over sodium sulfate, filtered, and concentrated to give 2,3,4,7-tetrakis- $O$-trimethylsilylated intermediate as a colorless oil. This material was dissolved in methanol $(500 \mu \mathrm{L})$, and $80 \%$ v/v acetic acid-water $(75 \mu \mathrm{L})$ was added. Desilylation was monitored by TLC, and after $1.5 \mathrm{~h}$, complete disappearance of starting material $\left(\mathrm{R}_{f}=0.50,20 \%\right.$ ethyl acetate-hexanes, CAM) was observed. The mixture was neutralized with the addition of saturated aqueous sodium bicarbonate solution $(200 \mu \mathrm{L})$, and the basified mixture was concentrated to dryness. The dried residue was partitioned between water $(10 \mathrm{~mL})$ and $50 \%$ ethyl ether-hexanes $(10 \mathrm{~mL})$, the biphasic mixture was agitated, and the layers were separated. The organic product solution was then washed with a fresh portion of water $(5 \mathrm{~mL})$, dried over sodium 
sulfate, filtered, and concentrated to give 2,3,4,-tris- $O$-trimethylsilylated intermediate as a colorless oil.

This material was transferred to a clean 1-mL glass vial containing a magnetic stir bar, where it was dissolved in chloroform $(123 \mu \mathrm{L})$. The solution was chilled to $0{ }^{\circ} \mathrm{C}$ before triethylamine $(12.8 \mu \mathrm{L}, 92.0 \mu \mathrm{mol}, 2.50$ equiv $)$ and methanesulfonyl chloride $(5.73 \mu \mathrm{L}, 73.6 \mu \mathrm{mol}$, 2.00 equiv) were added sequentially by micropipette. After 5 min of stirring at $0{ }^{\circ} \mathrm{C}$, TLC analysis (40\% ethyl acetate-hexanes, CAM) indicated that no 2,3,4,-tris- $O$-trimethylsilylated intermediate remained. The reaction mixture was diluted with dichloromethane $(5 \mathrm{~mL})$, and the mixture was washed with saturated aqueous sodium bicarbonate solution $(2 \times 2 \mathrm{~mL})$. The washed product solution was then dried over sodium sulfate, filtered, and concentrated to give 2,3,4-tris- $O$ trimethylsilyl-7-O-methanesulfonyl intermediate as a foaming, off-white solid.

Finally, in a 1-mL glass vial, methanesulfonate ester intermediate $(25.6 \mathrm{mg}, 30.5 \mu \mathrm{mol}, 1$ equiv), (4-mercaptophenyl)(morpholino)methanone (S29, $13.6 \mathrm{mg}, 61.0 \mu \mathrm{mol}, 2.00$ equiv), ${ }^{30}$ and potassium carbonate $(12.7 \mathrm{mg}, 91.5 \mu \mathrm{mol}, 3.00$ equiv) were suspended in $N, N$-dimethylformamide $(76.0 \mu \mathrm{L})$. This mixture was heated to $80{ }^{\circ} \mathrm{C}$ for $1.5 \mathrm{~h}$, whereupon TLC analysis (40\% ethyl acetate-hexanes, UV+PAA) showed that no sulfonate ester intermediate remained. The reaction mixture was diluted with ethyl acetate $(5 \mathrm{~mL})$, the diluted solution was washed with water $(2 \times 1$ $\mathrm{mL}$ ), and the washed solution was concentrated. The residue was re-dissolved in $50 \% \mathrm{v} / \mathrm{v}$ acetic acid-methanol $(2 \mathrm{~mL})$, and the resulting solution was stirred at $40{ }^{\circ} \mathrm{C}$ overnight in order to effect global desilylation. The desilylated product mixture was concentrated to dryness, and the dried residue was subjected to flash-column chromatography (4 g silica gel, eluting with

\footnotetext{
${ }^{30}$ Ahlmark, M.; Din Belle, D.; Kauppala, M.; Luiro, A.; Pajunen, T.; Pystynen, J.; Tianen, E.; Vaismaa, M.; Messinger, J. WO patent 2013/175053 A1, November 28, 2013.
} 
dichloromethane initially, grading to $10 \%$ methanol-dichloromethane) to furnish $\mathbf{S 3 0}$ as a colorless oil (18.2 mg, 69\% overall).

$\mathrm{R}_{f}=0.26$ (10\% methanol-dichloromethane, UV+PAA).

${ }^{1} \mathrm{H}$ NMR $\left(500 \mathrm{MHz}, \mathrm{CDCl}_{3}\right) \delta 7.44(\mathrm{~d}, J=8.4 \mathrm{~Hz}, 2 \mathrm{H}), 7.37(\mathrm{~d}, J=8.3 \mathrm{~Hz}, 2 \mathrm{H}), 6.68(\mathrm{~d}, J=9.2$ $\mathrm{Hz}, 1 \mathrm{H}), 5.44(\operatorname{app~t}, J=6.8 \mathrm{~Hz}, 1 \mathrm{H}), 4.55(\mathrm{dd}, J=11.5,3.5 \mathrm{~Hz}, 1 \mathrm{H}), 4.43(\mathrm{dt}, J=47.3$, $6.0 \mathrm{~Hz}, 2 \mathrm{H}), 4.19(\operatorname{app} \mathrm{td}, J=9.6,2.2 \mathrm{~Hz}, 1 \mathrm{H}), 4.14-4.07(\mathrm{~m}, 1 \mathrm{H}), 4.01$ (dd, $J=9.6,6.0$ $\mathrm{Hz}, 1 \mathrm{H}), 3.88-3.77(\mathrm{~m}, 3 \mathrm{H}), 3.76-3.76(\mathrm{~m}, 7 \mathrm{H}), 3.20(\mathrm{dd}, J=9.6,6.2 \mathrm{~Hz}, 1 \mathrm{H}), 2.81-2.77$ (br, 1H), 2.76-2.49 (br, 1H), 2.48-2.35 (br, 1H), 2.34-2.26 (m, 1H), 2.02-1.95 (m, 2H), $1.70-1.59(\mathrm{~m}, 2 \mathrm{H}), 1.54-1.41(\mathrm{~m}, 11 \mathrm{H}), 1.29-1.23(\mathrm{~m}, 3 \mathrm{H}), 1.03-0.96(\mathrm{br}, 1 \mathrm{H}), 0.74-0.67$ (br, 1H), 0.42-0.28 (br, 2H), 0.26-0.15 (br, 1H).

MS (ESI+, $m / z):[\mathrm{M}+\mathrm{H}]^{+}$calc'd for $\mathrm{C}_{38} \mathrm{H}_{56} \mathrm{FN}_{3} \mathrm{O}_{9} \mathrm{~S}, 750.4$; found 750.4. 


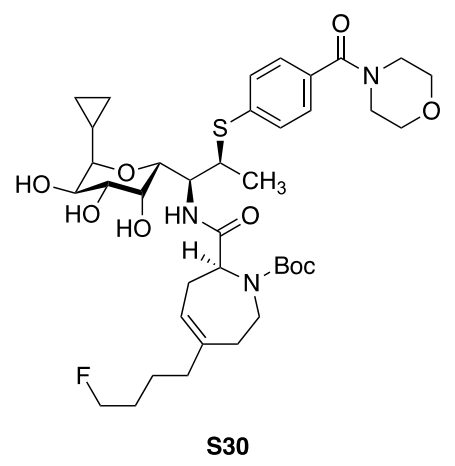

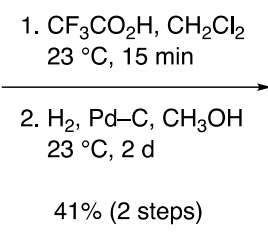

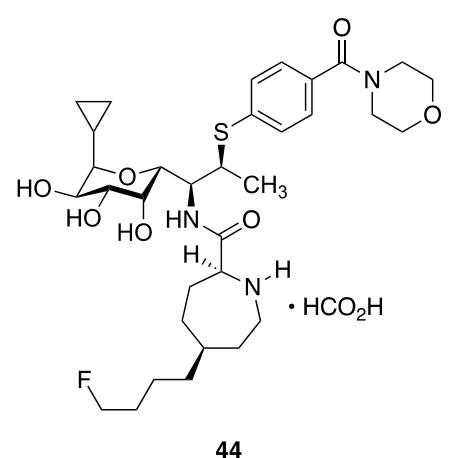

\section{Synthetic lincosamide 44.}

In a 4-mL glass vial fitted with a magnetic stir bar and silicone septum screw-cap, azepine S30 (18.2 mg, $24.3 \mu \mathrm{mol}, 1$ equiv) was dissolved in 33\% v/v trifluoroacetic acid-dichloromethane $(450 \mu \mathrm{L})$, and the resulting solution was stirred at $23{ }^{\circ} \mathrm{C}$. After $15 \mathrm{~min}$, LCMS analysis indicated that Boc removal was complete; toluene $(1 \mathrm{~mL})$ was added, and the mixture was concentrated to dryness. The residue was then re-dissolved in methanol $(500 \mu \mathrm{L})$, palladium on carbon $(10 \% \mathrm{w} / \mathrm{w}$, $20 \mathrm{mg}$ ) was added, the headspace above the reaction mixture was replaced with hydrogen gas, and the mixture was stirred at $23{ }^{\circ} \mathrm{C}$ under a balloonful of hydrogen gas. After $2 \mathrm{~d}$, LCMS showed that azepine hydrogenation was $\sim 75 \%$ complete, and the mixture was filtered through a Celite pad to remove the heterogeneous catalyst. The filter cake was rinsed with methanol $(3 \times 1 \mathrm{~mL})$, and the filtrate was concentrated to give a colorless oil. This residue was purified by preparative HPLC on a Waters SunFire Prep $C_{18}$ column $(5 \mu \mathrm{m}, 250 \times 19 \mathrm{~mm}$; eluting with $0.1 \%$ formic acid-10\% acetonitrile-water initially, grading to $0.1 \%$ formic acid-50\% acetonitrile-water over 30 min, with a flow rate of $15 \mathrm{~mL} / \mathrm{min}$; monitored by $\mathrm{UV}$ absorbance at $254 \mathrm{~nm})$ to provide $44 \cdot \mathrm{HCO}_{2} \mathrm{H}(6.9$ $\mathrm{mg}, 41 \%)$ as a white solid.

${ }^{1} \mathrm{H}$ NMR (600 MHz, CD $\left.3 \mathrm{OD}\right) \delta 8.38(\mathrm{br}, 1 \mathrm{H}), 7.47(\mathrm{~d}, J=8.4 \mathrm{~Hz}, 2 \mathrm{H}), 7.40(\mathrm{~d}, J=8.3 \mathrm{~Hz}, 2 \mathrm{H})$, $4.54(\mathrm{dd}, J=9.8,2.3 \mathrm{~Hz}, 1 \mathrm{H}), 4.42(\mathrm{dt}, J=47.5,6.0 \mathrm{~Hz}, 2 \mathrm{H}), 4.12-4.08(\mathrm{~m}, 2 \mathrm{H}), 4.00(\mathrm{qd}$, 
$J=6.8,2.2 \mathrm{~Hz}, 1 \mathrm{H}), 3.97(\mathrm{dd}, J=10.1,6.1 \mathrm{~Hz}, 1 \mathrm{H}), 3.88(\mathrm{~d}, J=3.3 \mathrm{~Hz}, 1 \mathrm{H}), 3.77(\mathrm{dd}, J$ $=10.2,3.3 \mathrm{~Hz}, 1 \mathrm{H}), 3.76-3.69(\mathrm{br}, 4 \mathrm{H}), 3.68-3.60(\mathrm{br}, 2 \mathrm{H}), 3.57-3.48(\mathrm{br}, 2 \mathrm{H}), 3.45(\mathrm{dd}$, $J=13.5,4.3 \mathrm{~Hz}, 1 \mathrm{H}), 3.14(\operatorname{app} \mathrm{t}, J=12.6 \mathrm{~Hz}, 3.06(\mathrm{dd}, J=10.1,6.1 \mathrm{~Hz}, 1 \mathrm{H}), 2.27-2.16$ (m, 2H), 2.06-2.00 (m, 1H), 1.96-1.91 (m, 1H), 1.72-1.55 (m, 4H), 1.48-1.41 (m, 3H), $1.38(\mathrm{~d}, J=6.9 \mathrm{~Hz}, 3 \mathrm{H}), 1.37-1.33(\mathrm{~m}, 2 \mathrm{H}), 1.07$ (tdd, $J=12.9,6.6,4.0 \mathrm{~Hz}, 1 \mathrm{H}), 0.64-$ $0.59(\mathrm{~m}, 1 \mathrm{H}), 0.28(\mathrm{dq}, J=9.5,4.8 \mathrm{~Hz}, 1 \mathrm{H}), 0.10(\mathrm{tt}, J=8.5,5.1 \mathrm{~Hz}, 1 \mathrm{H}), 0.04$ (ddd, $J=$ $11.0,9.3,5.1 \mathrm{~Hz}, 1 \mathrm{H})$.

HRMS (ESI+, $m / z)$ : $[\mathrm{M}+\mathrm{H}]^{+}$calc'd for $\mathrm{C}_{33} \mathrm{H}_{50} \mathrm{FN}_{3} \mathrm{O}_{7} \mathrm{~S}, 652.3426$; found 652.3443 . 

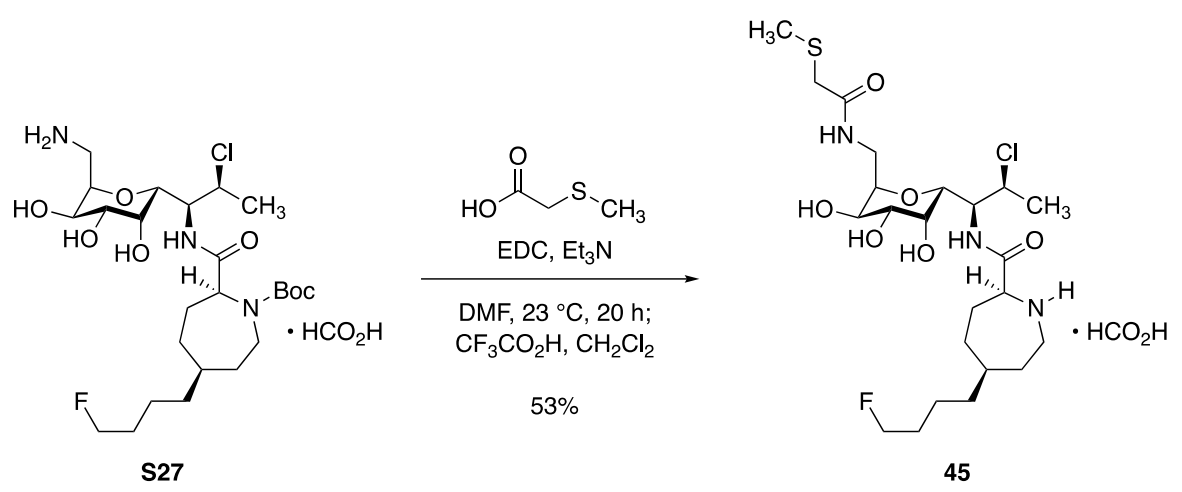

\section{Synthetic lincosamide 45.}

A 1-mL vial was charged sequentially with aminotriol S27 (5.0 mg, $8.3 \mu \mathrm{mol}, 1$ equiv), $N, N$-dimethylformamide $(83 \mu \mathrm{L})$, triethylamine $(3.5 \mu \mathrm{L}, 25 \mu \mathrm{mol}, 3.0$ equiv), and 2(methylthio)acetic acid (1.1 $\mu \mathrm{L}, 10 \mu \mathrm{mol}, 1.2$ equiv). $N$-(3-Dimethylaminopropyl- $N$ 'ethylcarbodiimide hydrochloride (EDC, $1.8 \mathrm{mg}, 9.2 \mu \mathrm{mol}, 1.1$ equiv) was then added. The resulting solution was stirred at $23{ }^{\circ} \mathrm{C}$ for $1 \mathrm{~h}$, at which time additional triethylamine $(6.0 \mu \mathrm{L}, 43$ $\mu$ mol, 5.2 equiv) and 2-(methylthio)acetic acid (1.1 $\mu \mathrm{L}, 10 \mu \mathrm{mol}, 1.2$ equiv) were added. After 19 h, LCMS analysis showed no starting material remained. Methanol $(200 \mu \mathrm{L})$ and toluene $(200 \mu \mathrm{L})$ were added, and the resulting solution was concentrated to dryness. The residue was then redissolved in $33 \%$ trifluoroacetic acid-dichloromethane $(200 \mu \mathrm{L})$, and after $30 \mathrm{~min}$ of stirring at 23 ${ }^{\circ} \mathrm{C}$, LCMS analysis indicated that Boc removal was complete. Toluene (300 $\left.\mu \mathrm{L}\right)$ was added, and the resulting solution was concentrated to dryness. The crude residue was purified by preparative HPLC on a Waters SunFire Prep $\mathrm{C}_{18}$ column $(5 \mu \mathrm{m} 250 \times 19 \mathrm{~mm}$, eluting with $0.1 \%$ formic acid$5 \%$ acetonitrile-water, grading to $0.1 \%$ formic acid-50\% acetonitrile-water over $30 \mathrm{~min}$, with a flow rate of $15 \mathrm{~mL} / \mathrm{min}$; monitored by $\mathrm{UV}$ absorbance at $210 \mathrm{~nm})$ to afford $45 \cdot \mathrm{HCO}_{2} \mathrm{H}(2.6 \mathrm{mg}$, $53 \%)$ as a white solid. 


\section{5 - $\mathrm{HCO}_{2} \mathrm{H}$ :}

${ }^{1} \mathrm{H}$ NMR (600 MHz, CD $\left.3 \mathrm{OD}\right) \delta 4.70(\mathrm{q}, J=6.3 \mathrm{~Hz}, 1 \mathrm{H}), 4.47-4.43(\mathrm{~m}, 1 \mathrm{H}), 4.42(\mathrm{dd}, J=47.4$, $5.9 \mathrm{~Hz}, 2 \mathrm{H}), 4.17(\mathrm{ddd}, J=10.5,6.4,4.0 \mathrm{~Hz}, 1 \mathrm{H}), 4.06-3.99(\mathrm{~m}, 2 \mathrm{H}), 3.82(\mathrm{~d}, J=3.3 \mathrm{~Hz}$, 1H), $3.70(\mathrm{~d}, J=9.6 \mathrm{~Hz}, 1 \mathrm{H}), 3.65-3.53(\mathrm{~m}, 3 \mathrm{H}), 3.37(\mathrm{ddd}, J=13.9,6.3,3.2 \mathrm{~Hz}, 1 \mathrm{H})$, $3.20(\operatorname{app~q}, J=15.1 \mathrm{~Hz}, 2 \mathrm{H}), 2.37-2.30(\mathrm{~m}, 1 \mathrm{H}), 2.15(\mathrm{~s}, 3 \mathrm{H}), 2.09-2.02(\mathrm{~m}, 2 \mathrm{H}), 1.93$ $(\operatorname{app~q}, J=12.6 \mathrm{~Hz}, 1 \mathrm{H}), 1.74-1.53(\mathrm{~m}, 4 \mathrm{H}), 1.50-1.45(\mathrm{~m}, 2 \mathrm{H}), 1.44(\mathrm{~d}, J=6.9 \mathrm{~Hz}, 3 \mathrm{H})$, 1.43-1.34 (m, 3H). One methylene proton corresponding to the $\zeta$ position of the azepane is obfuscated by $\mathrm{CHD}_{2} \mathrm{OD}$ signal.

HRMS (ESI+, $m / z)$ : $[\mathrm{M}+\mathrm{H}]^{+}$calc'd for $\mathrm{C}_{23} \mathrm{H}_{41} \mathrm{ClFN}_{3} \mathrm{O}_{6} \mathrm{~S}, 542.2461$; found 542.2451. 

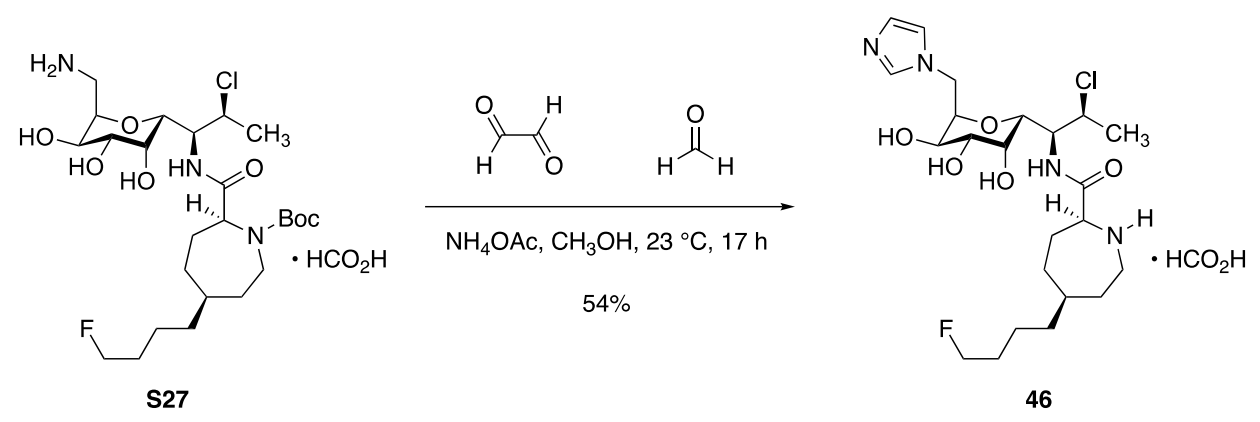

\section{Synthetic lincosamide 46.}

To a 1-mL vial, aminotriol S27 $(5.0 \mathrm{mg}, 9.02 \mu \mathrm{mol}$, 1 equiv), methanol $(180 \mu \mathrm{L})$, ammonium acetate $(2.1 \mathrm{mg}, 27 \mu \mathrm{mol}, 3.0$ equiv), glyoxal ( $40 \% \mathrm{w} / \mathrm{w}$ aqueous solution, $3.9 \mu \mathrm{L}, 27$ $\mu$ mol, 3.0 equiv), and formalin ( $37 \% \mathrm{w} / \mathrm{w}, 2.0 \mu \mathrm{L}, 27 \mu \mathrm{mol}, 3.0$ equiv) were added sequentially. The mixture was stirred at $23^{\circ} \mathrm{C}$. After $3 \mathrm{~h}$, additional glyoxal $(3.9 \mu \mathrm{L}, 3.0$ equiv) and formalin (2.0 $\mu \mathrm{L}, 3.0$ equiv) were added. After an additional $14 \mathrm{~h}$, no starting material remained by LCMS, and the mixture was diluted with benzene $(300 \mu \mathrm{L})$. The mixture was concentrated, and the dried residue was re-dissolved in 33\% trifluoroacetic acid-dichloromethane $(200 \mu \mathrm{L})$. After $30 \mathrm{~min}$ of stirring at $23{ }^{\circ} \mathrm{C}$, LCMS analysis indicated that Boc removal was complete. Toluene (500 $\left.\mu \mathrm{L}\right)$ was added, and the mixture was concentrated. The dried residue was purified by preparative HPLC on a Waters SunFire Prep $C_{18}$ column $(5 \mu \mathrm{m}, 250 \times 19 \mathrm{~mm}$; eluting with $0.1 \%$ formic acid-5\% acetonitrile-water initially, grading to $1 \%$ formic acid-50\% acetonitrile-water over $40 \mathrm{~min}$, with a flow rate of $15 \mathrm{~mL} / \mathrm{min}$; monitored by $\mathrm{UV}$ absorbance at $210 \mathrm{~nm}$ ) to afford $46 \cdot \mathrm{HCO}_{2} \mathrm{H}$ as a white solid (2.9 mg, 54\%).

${ }^{1} \mathrm{H}$ NMR (600 MHz, CD 3 OD) $\delta 8.78(\mathrm{~s}, 1 \mathrm{H}), 8.10(\mathrm{br}, 1 \mathrm{H}), 7.65(\mathrm{~s}, 1 \mathrm{H}), 7.51(\mathrm{~s}, 1 \mathrm{H}), 4.66-4.52$ (m, 3H), 4.47-4.44 (m, 1H), $4.43(\mathrm{dd}, J=47.2,6.0 \mathrm{~Hz}, 2 \mathrm{H}), 4.25$ (app q, $J=6.6 \mathrm{~Hz}, 1 \mathrm{H})$, $4.14(\mathrm{dd}, J=9.7,6.3 \mathrm{~Hz}, 1 \mathrm{H}), 4.10-4.05(\mathrm{~m}, 1 \mathrm{H}), 3.92-3.89(\mathrm{~m}, 1 \mathrm{H}), 3.84(\mathrm{~d}, J=9.6 \mathrm{~Hz}$, 
1H), $3.67(\mathrm{dd}, J=9.9,3.0 \mathrm{~Hz}, 1 \mathrm{H}), 3.38(\mathrm{ddd}, J=14.3,6.2,3.3 \mathrm{~Hz}, 1 \mathrm{H}), 2.33(\mathrm{dd}, J=14.8$, $6.3 \mathrm{~Hz}, 1 \mathrm{H}), 2.09-2.02(\mathrm{~m}, 2 \mathrm{H}), 1.92(\operatorname{app~q}, J=12.2 \mathrm{~Hz}, 1 \mathrm{H}), 1.74-1.53(\mathrm{~m}, 4 \mathrm{H}), 1.50-$ $1.38(\mathrm{~m}, 5 \mathrm{H}), 1.37(\mathrm{~d}, J=7.0 \mathrm{~Hz}, 3 \mathrm{H})$. One methylene proton corresponding to the $\zeta$ position of the azepane is obfuscated by $\mathrm{CHD}_{2} \mathrm{OD}$ signal.

HRMS (ESI+, $m / z):[\mathrm{M}+\mathrm{H}]^{+}$calc'd for $\mathrm{C}_{23} \mathrm{H}_{38} \mathrm{ClFN}_{4} \mathrm{O}_{5}$, 505.2588; found 505.2590. 

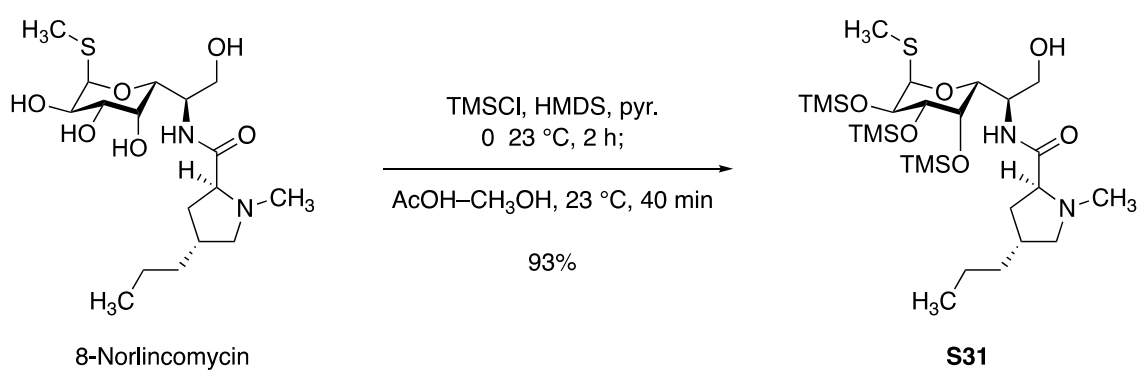

(42)

\section{Alcohol S31.}

In a 2-5-mL glass microwave vial, an ice-cold solution of 8-norlincomycin $(\mathbf{4 2}, 90.0 \mathrm{mg}$, $229 \mu \mathrm{mol}, 1$ equiv) in pyridine $(382 \mu \mathrm{L})$ was treated sequentially with hexamethyldisilazane $(121$ $\mu \mathrm{L}, 578 \mu \mathrm{mol}, 2.52$ equiv) and chlorotrimethylsilane (168 $\mu \mathrm{L}, 1.31 \mathrm{mmol}, 5.72$ equiv). Following the addition of these reagents, the mixture was warmed to $23{ }^{\circ} \mathrm{C}$, and stirring was maintained for $2 \mathrm{~h}$. The mixture was then concentrated to dryness in vacuo, and the residue was partitioned between hexanes $(10 \mathrm{~mL})$ and water $(10 \mathrm{~mL})$. The layers were separated, and the aqueous phase was extracted with additional hexanes $(3 \times 5 \mathrm{~mL})$. The combined organic extracts were then dried over sodium sulfate, the dried solution was filtered, and the filtrate was concentrated to afford crude, persilylated 8-norlincomycin as a brilliant white solid. This material was then suspended in methanol $(887 \mu \mathrm{L})$, and $80 \%$ v/v acetic acid-water $(133 \mu \mathrm{L})$ was added to the suspension, causing the mixture to become a homogeneous, colorless solution. Desilylation was monitored by TLC (40\% ethyl acetate-hexanes, CAM; persilylated intermediate $\mathrm{R}_{f}=0.64$; alcohol product $\mathrm{R}_{f}=0.16$ ), and after $40 \mathrm{~min}$ of stirring at $23^{\circ} \mathrm{C}$, the reaction was judged to be complete. The reaction mixture was transferred to a separatory funnel containing hexanes $(10 \mathrm{~mL})$ and saturated aqueous sodium bicarbonate solution $(10 \mathrm{~mL})$. The mixture was shaken vigorously, and the layers were separated. The aqueous layer was extracted with fresh hexanes $(3 \times 5 \mathrm{~mL})$, and the combined organic extracts were washed with saturated aqueous sodium chloride solution $(10 \mathrm{~mL})$. The washed organic 
solution was then dried over sodium sulfate, filtered, and concentrated to provide 2,3,4-tris- $O$ trimethylsilyl-8-norlincomycin (S31) as a white, foaming, amorphous solid (115 mg, 93\%).

$\mathrm{R}_{f}=0.16$ (40\% ethyl acetate-hexanes, CAM).

${ }^{1} \mathrm{H}$ NMR $\left(600 \mathrm{MHz}, \mathrm{CDCl}_{3}\right) \delta 7.73(\mathrm{~d}, J=8.8 \mathrm{~Hz}, 1 \mathrm{H}), 5.22(\mathrm{~d}, J=5.6 \mathrm{~Hz}, 1 \mathrm{H}), 4.17-4.11(\mathrm{~m}$, $3 \mathrm{H}), 3.92(\mathrm{br} \mathrm{d}, J=11.0 \mathrm{~Hz}, 1 \mathrm{H}), 3.81(\mathrm{~d}, J=2.6 \mathrm{~Hz}, 1 \mathrm{H}), 3.70($ br d, $J=10.8 \mathrm{~Hz}, 1 \mathrm{H})$, $3.66(\mathrm{dd}, J=9.4,2.6 \mathrm{~Hz}, 1 \mathrm{H}), 3.16-3.12(\mathrm{~m}, 1 \mathrm{H}), 2.94(\mathrm{dd}, J=10.8,4.2 \mathrm{~Hz}, 1 \mathrm{H}), 2.57(\mathrm{br}$, $1 \mathrm{H}), 2.34(\mathrm{~s}, 3 \mathrm{H}), 2.07(\mathrm{~s}, 3 \mathrm{H}), 2.04-2.02(\mathrm{~m}, 2 \mathrm{H}), 1.97-1.93(\mathrm{~m}, 1 \mathrm{H}), 1.85-1.80(\mathrm{~m}, 1 \mathrm{H})$, $1.30-1.24(\mathrm{~m}, 4 \mathrm{H}), 0.87$ (t, $J=6.7 \mathrm{~Hz}, 3 \mathrm{H}), 0.17$ (s, 9H), $0.12(\mathrm{~s}, 9 \mathrm{H}), 0.11(\mathrm{~s}, 9 \mathrm{H})$.

${ }^{13} \mathrm{C}$ NMR $\left(126 \mathrm{MHz}, \mathrm{CDCl}_{3}\right) \delta$ 174.8, 88.3, $72.6(2 \times \mathrm{C}), 70.9,69.0,68.9,62.9,62.8,50.0,42.0$, $38.3,37.8,35.8,21.7,14.4,12.7,0.9,0.5,0.3$.

FTIR (neat, $\left.\mathrm{cm}^{-1}\right): 2957(\mathrm{~m}), 1659(\mathrm{~m}), 1518(\mathrm{~m}), 1250(\mathrm{~m}), 1132(\mathrm{~m}), 1070(\mathrm{~m}), 893(\mathrm{~s}), 839(\mathrm{~s})$. HRMS (ESI+, $m / z$ ): $[\mathrm{M}+\mathrm{H}]^{+}$calc'd for $\mathrm{C}_{26} \mathrm{H}_{56} \mathrm{~N}_{2} \mathrm{O}_{6} \mathrm{SSi}_{3}$, 609.3240; found 609.3259. 

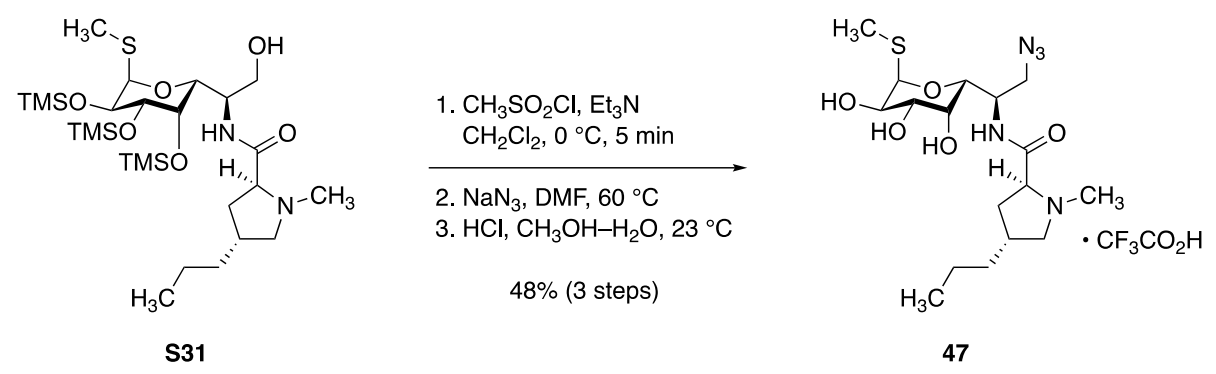

\section{Synthetic lincosamide 47.}

In a 1-mL glass vial fitted with a magnetic stir bar and a PTFE-lined screw cap, 2,3,4-tris$O$-trimethylsilyl-8-norlincomycin (S31, $20 \mathrm{mg}, 33 \mu \mathrm{mol}, 1$ equiv) was dissolved in chloroform $(160 \mu \mathrm{L})$. Triethylamine (11 $\mu \mathrm{L}, 82 \mu \mathrm{mol}, 2.5$ equiv) was added, the vial was sealed, and the solution was chilled to $0{ }^{\circ} \mathrm{C}$. Methanesulfonyl chloride $(5.1 \mu \mathrm{L}, 66 \mu \mathrm{mol}, 2.0$ equiv) was then added, the vial re-sealed, and the mixture stirred at $0{ }^{\circ} \mathrm{C}$ for $5 \mathrm{~min}$, whereupon TLC analysis ( $10 \%$ methanol-dichloromethane, PAA) revealed that all of the starting material had been consumed. The reaction mixture was diluted with dichloromethane $(1 \mathrm{~mL})$, and the diluted mixture was transferred to a separatory funnel containing hexanes $(10 \mathrm{~mL})$ and saturated aqueous sodium bicarbonate solution $(10 \mathrm{~mL})$. The biphasic mixture was shaken vigorously for $1 \mathrm{~min}$ before the layers were separated; the aqueous layer was extracted with fresh hexanes $(2 \times 5 \mathrm{~mL})$, and the combined organic extracts were washed with saturated aqueous sodium chloride solution $(5 \mathrm{~mL})$. The washed organic solution was dried over sodium sulfate, filtered, and concentrated to give crude methanesulfonate ester intermediate as a white solid. This material was transferred to a 4$\mathrm{mL}$ glass vial and was dried by azeotropic removal of benzene before sodium azide ( $21 \mathrm{mg}, 330$ $\mu$ mol, 10 equiv) and $N, N$-dimethylformamide $(330 \mu \mathrm{L})$ were added. The vial was sealed with a PTFE-lined screw cap, and the reaction mixture was heated to $60^{\circ} \mathrm{C}$ in a pre-heated oil bath. After $18 \mathrm{~h}$, LCMS analysis showed that all the intermediate sulfonate ester had been consumed, and the product mixture was transferred to a separatory funnel containing $50 \% \mathrm{v} / \mathrm{v}$ saturated aqueous 
sodium bicarbonate solution-saturated aqueous sodium chloride solution $(10 \mathrm{~mL})$. This mixture was then extracted with ethyl acetate $(4 \times 5 \mathrm{~mL})$, the combined organic extracts were dried over sodium sulfate, the dried product solution was filtered, and the filtrate was concentrated. The residue thus obtained was then re-dissolved in 50\% v/v methanol-1N aqueous hydrogen chloride solution; after 30 min of stirring this mixture, LCMS analysis showed that global desilylation was complete, and the mixture was passed through a 0.2- $\mu \mathrm{m}$ PTFE filter. The filtrate was concentrated, and the crude residue was subjected to preparative HPLC on a Waters SunFire Prep $\mathrm{C}_{18}$ column $(5 \mu \mathrm{m}, 250 \times 19 \mathrm{~mm}$; eluting with $0.1 \%$ trifluoroacetic acid-water, grading to $0.1 \%$ trifluoroacetic acid-40\% acetonitrile-water over $40 \mathrm{~min}$, with a flow rate of $15 \mathrm{~mL} / \mathrm{min}$; monitored by UV absorbance at $\left.210 \mathrm{~nm} ; \mathrm{R}_{t}=28.6 \mathrm{~min}\right)$ to provide azide analog $47 \cdot \mathrm{CF}_{3} \mathrm{CO}_{2} \mathrm{H}$ as a white solid (8.4 $\mathrm{mg}, 48 \%)$.

${ }^{1} \mathrm{H}$ NMR $\left(600 \mathrm{MHz}, \mathrm{CD}_{3} \mathrm{OD}\right) \delta 5.29(\mathrm{~d}, J=5.7 \mathrm{~Hz}, 1 \mathrm{H}), 4.42(\mathrm{ddd}, J=9.3,5.8,3.3 \mathrm{~Hz}, 1 \mathrm{H}), 4.22$ $(\mathrm{dd}, J=9.5,1.3 \mathrm{~Hz}, 1 \mathrm{H}), 4.18(\mathrm{dd}, J=9.7,6.6 \mathrm{~Hz}, 1 \mathrm{H}), 4.09(\mathrm{dd}, J=10.2,5.6 \mathrm{~Hz}, 1 \mathrm{H})$, $3.85(\mathrm{dd}, J=3.4,1.3 \mathrm{~Hz}, 1 \mathrm{H}), 3.77(\mathrm{dd}, J=11.1,6.8 \mathrm{~Hz}, 1 \mathrm{H}), 3.69$ (dd, $J=12.7,3.4 \mathrm{~Hz}$ 1H), $3.59(\mathrm{dd}, J=10.2,3.3 \mathrm{~Hz}, 1 \mathrm{H}), 3.53(\mathrm{dd}, J=12.7,5.9 \mathrm{~Hz}, 1 \mathrm{H}), 2.94(\mathrm{~s}, 3 \mathrm{H}), 2.89$ (app t, $J=11.0 \mathrm{~Hz}, 1 \mathrm{H}), 2.39-2.32(\mathrm{~m}, 1 \mathrm{H}), 2.29-2.24(\mathrm{~m}, 2 \mathrm{H}), 2.10(\mathrm{~s}, 3 \mathrm{H}), 1.52-1.45$ (m, 2H), 1.39-1.34 (m, 2H), $0.95(\mathrm{t}, J=7.3 \mathrm{~Hz}, 3 \mathrm{H})$.

${ }^{13} \mathrm{C}$ NMR $\left(100 \mathrm{MHz}, \mathrm{CD}_{3} \mathrm{OD}\right) \delta 169.0,89.5,72.0,69.9,69.8,69.6,69.4,62.3,52.7,50.8,41.1$, $38.0,36.4,35.7,22.1,14.2,13.1$.

FTIR (neat, $\mathrm{cm}^{-1}$ ): 3367 (br), 2927 (w), 2105 (s), 1671 (s), 1453 (m), 1202 (s), 1136 (m). HRMS (ESI+, m/z): $[\mathrm{M}+\mathrm{H}]^{+}$calc'd for $\mathrm{C}_{17} \mathrm{H}_{31} \mathrm{~N}_{5} \mathrm{O} 5 \mathrm{~S}, 418.2119$; found 418.2132. 

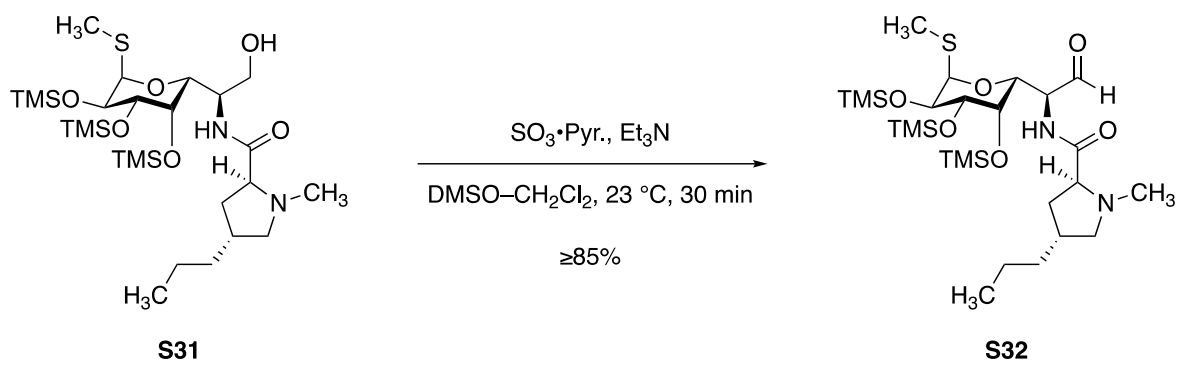

\section{Aldehyde S32.}

To a solution of 2,3,4-tris- $O$-trimethylsilyl-8-norlincomycin $(\mathbf{S 3 1}, 50 \mathrm{mg}, 82 \mu \mathrm{mol}, 1$ equiv) in dichloromethane $(660 \mu \mathrm{L})$ and dimethyl sulfoxide $(160 \mu \mathrm{L})$ were added triethylamine (92 $\mu \mathrm{L}, 660 \mu \mathrm{mol}, 8.0$ equiv) and sulfur trioxide-pyridine complex (52 mg, $330 \mu \mathrm{mol}, 4.0$ equiv) at $23{ }^{\circ} \mathrm{C}$. After $15 \mathrm{~min}$, TLC analysis (10\% methanol-dichloromethane, PAA) showed that reaction progress had stalled, and additional portions of triethylamine ( $92 \mu \mathrm{L}, 660 \mu \mathrm{mol}, 8.0$ equiv) and sulfur trioxide-pyridine complex ( $52 \mathrm{mg}, 330 \mu \mathrm{mol}, 4.0$ equiv) were added. After an additional 15 min of stirring at $23{ }^{\circ} \mathrm{C}$, TLC analysis showed the reaction was complete. The mixture was diluted with dichloromethane $(10 \mathrm{~mL})$, and the diluted solution was transferred to a separatory funnel containing saturated aqueous sodium bicarbonate solution $(10 \mathrm{~mL})$. The layers were shaken vigorously, then separated, and the aqueous phase was extracted with fresh portions of dichloromethane $(3 \times 5 \mathrm{~mL})$. The combined organic extracts were then washed with saturated aqueous sodium chloride solution $(10 \mathrm{~mL})$ before being dried over sodium sulfate, filtered, and concentrated to provide crude aldehyde $\mathbf{S 3 2}$ as a dull white solid. This material was unstable toward column chromatography, and thus an analytically pure sample could not be obtained; instead, purity of $\geq 85 \%$ was assumed based on crude ${ }^{1} \mathrm{H}$ NMR analysis $\left(\mathrm{CDCl}_{3}\right)$, and this material was used directly in subsequent transformations, after which 2-step yields were determined. 

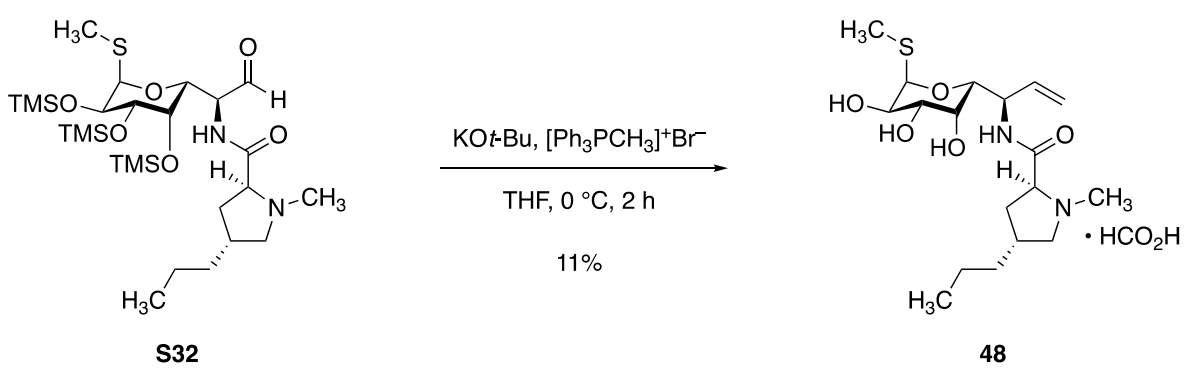

\section{Synthetic lincosamide 48.}

An oven-dried 4-mL glass vial was charged with a magnetic stir bar, methyltriphenylphosponium bromide ( $16 \mathrm{mg}, 46 \mu \mathrm{mol}, 1.4$ equiv), and tetrahydrofuran ( $330 \mu \mathrm{L}$ ). The vial was sealed with a silicone septum-lined screw cap, and the mixture was chilled to $0{ }^{\circ} \mathrm{C}$ before potassium tert-butoxide solution (1.0 M in tetrahydrofuran, $40 \mu \mathrm{L}, 40 \mu \mathrm{mol}, 1.2$ equiv) was added. Upon treatment with alkoxide base, the heterogeneous mixture immediately attained a vibrant, highlighter-yellow color. This mixture was stirred at $0{ }^{\circ} \mathrm{C}$ for $30 \mathrm{~min}$ before a solution of aldehyde $\mathbf{3 . 8 3}$ (theoretically $20 \mathrm{mg}, 33 \mu \mathrm{mol}, 1$ equiv) in tetrahydrofuran ( $330 \mu \mathrm{L})$ was added by cannula, causing the yellow color to disappear. After 5 min of stirring at $0{ }^{\circ} \mathrm{C}, \mathrm{TLC}$ analysis $(7 \%$ methanol-dichloromethane, PAA) revealed that no starting material remained, and excess Wittig reagent was quenched with the addition of acetone $(150 \mu \mathrm{L})$. The product mixture was diluted with hexanes $(15 \mathrm{~mL})$, dried over sodium sulfate, filtered, and concentrated to give a white film that was re-dissolved in $50 \% \mathrm{v} / \mathrm{v}$ methanol-1N aqueous hydrogen chloride solution $(1.5 \mathrm{~mL})$. This mixture was stirred at $23{ }^{\circ} \mathrm{C}$ for $1 \mathrm{~h}$, at which point LCMS analysis indicated that global desilylation was complete. The mixture was passed through a 0.2- $\mu \mathrm{m}$ PTFE filter, the filtrate was concentrated, and the crude residue was purified by preparative HPLC-MS on a Waters SunFire Prep $\mathrm{C}_{18}$ column $(5 \mu \mathrm{m}, 250 \times 19 \mathrm{~mm}$; eluting with $0.1 \%$ formic acid-water, grading to $0.1 \%$ formic acid-35\% acetonitrile-water over $40 \mathrm{~min}$, with a flow rate of $15 \mathrm{~mL} / \mathrm{min}$; monitored by 
UV absorbance at $210 \mathrm{~nm}$ and ESI+ selected ion monitoring $[\mathrm{m} / \mathrm{z}=389] ; \mathrm{R}_{t}=18.9 \mathrm{~min}$ ) to provide vinyl analog $48 \cdot \mathrm{HCO}_{2} \mathrm{H}$ as a white solid (1.5 mg, 11\%, 2 steps).

${ }^{1} \mathrm{H}$ NMR (600 MHz, CD $\left.3 \mathrm{OD}\right) \delta 8.37(\mathrm{~s}, 1 \mathrm{H}), 6.01(\mathrm{ddd}, J=17.3,10.5,5.5 \mathrm{~Hz}, 1 \mathrm{H}), 5.28(\mathrm{~d}, J=$ $5.6 \mathrm{~Hz}, 1 \mathrm{H}), 5.23(\operatorname{app} \mathrm{dt}, J=17.3,1.5 \mathrm{~Hz}, 1 \mathrm{H}), 5.21(\operatorname{app} \mathrm{dt}, J=10.4,1.4 \mathrm{~Hz}, 1 \mathrm{H}), 4.71$ (app ddt, $J=8.5,5.5,1.6 \mathrm{~Hz}, 1 \mathrm{H}), 4.11(\mathrm{dd}, J=10.1,5.7 \mathrm{~Hz}, 1 \mathrm{H}), 4.09$ (dd, $J=8.2,0.8$ $\mathrm{Hz}, 1 \mathrm{H}), 3.88(\mathrm{dd}, J=3.5,1.3 \mathrm{~Hz}, 1 \mathrm{H}), 3.59(\mathrm{dd}, J=10.1,3.3 \mathrm{~Hz}, 1 \mathrm{H}), 3.44-3.41(\mathrm{~m}, 1 \mathrm{H})$, $2.59(\mathrm{~s}, 3 \mathrm{H}), 2.38(\operatorname{app~t}, J=10.0 \mathrm{~Hz}, 1 \mathrm{H}), 2.30-2.23(\mathrm{~m}, 1 \mathrm{H}), 2.08(\mathrm{ddd}, J=13.5,8.3,5.4$ $\mathrm{Hz}, 1 \mathrm{H}), 2.04(\mathrm{~s}, 3 \mathrm{H}), 2.01-1.95(\mathrm{~m}, 1 \mathrm{H}), 1.42-1.32(\mathrm{~m}, 4 \mathrm{H}), 0.94(\mathrm{t}, J=7.1 \mathrm{~Hz}, 3 \mathrm{H})$. HRMS (ESI+, m/z): $[\mathrm{M}+\mathrm{H}]^{+}$calc'd for $\mathrm{C}_{18} \mathrm{H}_{32} \mathrm{~N}_{2} \mathrm{O}$ S S, 389.2105; found 389.2111. 

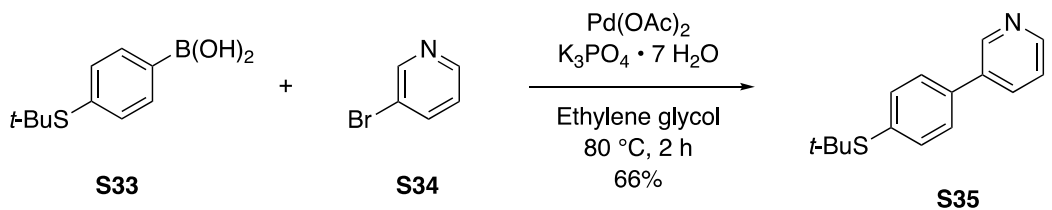

tert-Butane sulfide S35.

Ligand-free Suzuki coupling was performed according to the method of Liu, Han, Song, and Qiu. ${ }^{31}$ Taking no special precautions to exclude air or moisture, a 300-mL round-bottomed flask was charged with a magnetic stir bar, (4-(tert-butylthio)phenyl)boronic acid (S33, $4.79 \mathrm{~g}$, $22.8 \mathrm{mmol}, 1.20$ equiv), potassium phosphate heptahydrate (12.9 g, $38.0 \mathrm{mmol}, 2.00$ equiv), palladium(II) acetate (43.0 mg, $0.190 \mathrm{mmol}, 0.0100$ equiv), and ethylene glycol (146 mL). 3Bromopyridine (S34, $1.83 \mathrm{~mL}, 19.0 \mathrm{mmol}, 1$ equiv) was added last, stirring was initiated, and the reaction mixture was heated to $80{ }^{\circ} \mathrm{C}$ (open to the atmosphere) in a pre-heated oil bath. Within 30 min, the suspension had clarified, forming an amber-brown homogeneous solution; and after $1 \mathrm{~h}$, the mixture became a light tan, turbid suspension. After $2 \mathrm{~h}$ of stirring at $80{ }^{\circ} \mathrm{C}$, TLC analysis $(60 \%$ ethyl acetate-hexanes, UV) showed that no starting material remained. The mixture was cooled to $23{ }^{\circ} \mathrm{C}$ and was then poured into a separatory funnel containing saturated aqueous sodium chloride solution $(250 \mathrm{~mL})$. The aqueous suspension was extracted with ethyl ether $(4 \times 50 \mathrm{~mL})$, and the combined organic extracts were washed with a fresh portion of saturated aqueous sodium chloride solution $(50 \mathrm{~mL})$. The washed organic product solution was then dried over sodium sulfate, filtered, and concentrated to give a milky, light yellow oil that was purified by flash-column chromatography (120 g silica gel, eluting with $10 \%$ ethyl acetate-hexanes initially, grading to $40 \%$ ethyl acetate-hexanes) to provide the product as a brilliant white, fluffy powder $(3.04 \mathrm{~g}, 66 \%)$.

\footnotetext{
${ }^{31}$ Liu, C.; Han, N.; Song, X.; Qiu, J. Eur. J. Org Chem. 2010, 5548-5551.
} 
Melting point: $55-57^{\circ} \mathrm{C}$.

$\mathrm{R}_{f}=0.37$ (60\% ethyl acetate-hexanes, UV).

${ }^{1} \mathrm{H}$ NMR $\left(600 \mathrm{MHz}, \mathrm{CDCl}_{3}\right) \delta 8.86(\mathrm{~d}, J=1.7 \mathrm{~Hz}, 1 \mathrm{H}), 8.61(\mathrm{dd}, J=4.7,1.6 \mathrm{~Hz}, 1 \mathrm{H}), 7.88(\mathrm{ddd}$, $J=7.9,2.4,1.6 \mathrm{~Hz}, 1 \mathrm{H}), 7.64(\mathrm{~d}, J=8.3 \mathrm{~Hz}, 2 \mathrm{H}), 7.55(\mathrm{~d}, J=8.2 \mathrm{~Hz}, 2 \mathrm{H}), 7.38(\mathrm{ddd}, J=$ 7.8, 4.8, $0.9 \mathrm{~Hz}, 1 \mathrm{H}), 1.33(\mathrm{~s}, 9 \mathrm{H})$.

${ }^{13} \mathrm{C}$ NMR $\left(100 \mathrm{MHz}, \mathrm{CDCl}_{3}\right) \delta 148.9,148.4,138.2(2 \times \mathrm{C}), 136.0,134.4,133.0,127.2,123.7$, $46.4,31.1$.

FTIR (neat, $\mathrm{cm}^{-1}$ ): 2960 (s), 1573 (w), 1471 (s), 1363 (s), 1168 (m), 1001 (m), 800 (s), $711(\mathrm{~s})$, $561(\mathrm{~m})$.

HRMS (ESI+, $m / z)$ : $[\mathrm{M}+\mathrm{H}]^{+}$calc'd for $\mathrm{C}_{15} \mathrm{H}_{17} \mathrm{NS}, 244.1154$; found 244.1167 . 

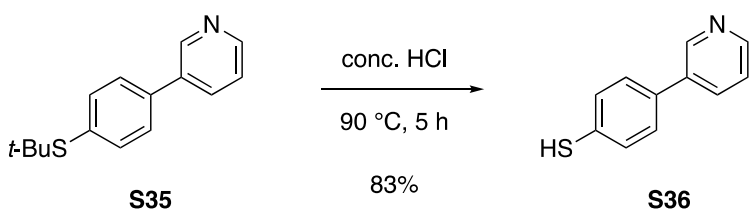

Biaryl thiol 2.39b.

In a 500-mL round-bottomed flask containing a magnetic stir bar, tert-butanesulfide $\mathbf{S 3 5}$ (3.00 g, $12.3 \mathrm{mmol}, 1$ equiv) and concentrated hydrochloric acid (38\% w/w in water, $123 \mathrm{~mL}$ ) were combined. The headspace was flushed with argon, and the mixture was heated to $90{ }^{\circ} \mathrm{C}$ with constant stirring; the starting material gradually dissolved upon warming. After $5 \mathrm{~h}$, LCMS analysis showed that no starting material remained, and the reaction mixture was cooled to $0{ }^{\circ} \mathrm{C}$. The chilled solution was basified with the careful addition of aqueous $6 \mathrm{~N}$ sodium hydroxide solution, until $\mathrm{pH}=8$ was achieved. The aqueous mixture was then extracted with ethyl ether $(4 \times$ $75 \mathrm{~mL}$ ), the combined extracts were dried over sodium sulfate, the dried solution was filtered, and the filtrate was concentrated to give a colorless oil. This crude residue was finally purified by flashcolumn chromatography ( 80 g silica gel, eluting with $20 \%$ ethyl acetate-hexanes initially, grading to $60 \%$ ethyl acetate-hexanes) to provide arenethiol product as a light yellow solid (1.92 $\mathrm{g}, 83 \%)$.

Melting point: $42-44^{\circ} \mathrm{C}$.

$\mathrm{R}_{f}=0.23$ (60\% ethyl acetate-hexanes, UV).

${ }^{1} \mathrm{H}$ NMR $\left(600 \mathrm{MHz}, \mathrm{CDCl}_{3}\right) \delta 8.79(\mathrm{~d}, J=2.4 \mathrm{~Hz}, 1 \mathrm{H}), 8.56(\mathrm{dd}, J=4.8,1.6 \mathrm{~Hz}, 1 \mathrm{H}), 7.79(\mathrm{dt}, J$ $=7.9,2.0 \mathrm{~Hz}, 1 \mathrm{H}), 7.42(\mathrm{~d}, J=8.3 \mathrm{~Hz}, 2 \mathrm{H}), 7.34(\mathrm{~d}, J=8.3 \mathrm{~Hz}, 2 \mathrm{H}), 7.32(\mathrm{dd}, J=7.9,4.9$ $\mathrm{Hz}, 1 \mathrm{H}), 3.55(\mathrm{~s}, 1 \mathrm{H})$.

${ }^{13} \mathrm{C}$ NMR $\left(100 \mathrm{MHz}, \mathrm{CDCl}_{3}\right) \delta$ 148.5, 148.0, 135.8, 135.1, 134.0, 131.4, 129.8, 127.7, 123.6. 
FTIR (neat, cm ${ }^{-1}$ ): 3027 (m), 2398 (br), 1903 (w), 1597 (m), 1468 (s), 1423 (m), 1393 (m), 1185 (m), 1103 (s), 1000 (s), 794 (s), 708 (s), 547 (s).

HRMS (ESI+, m/z): $[\mathrm{M}+\mathrm{H}]^{+}$calc'd for $\mathrm{C}_{11} \mathrm{H}_{9} \mathrm{NS}, 188.0528$; found 188.0526. 

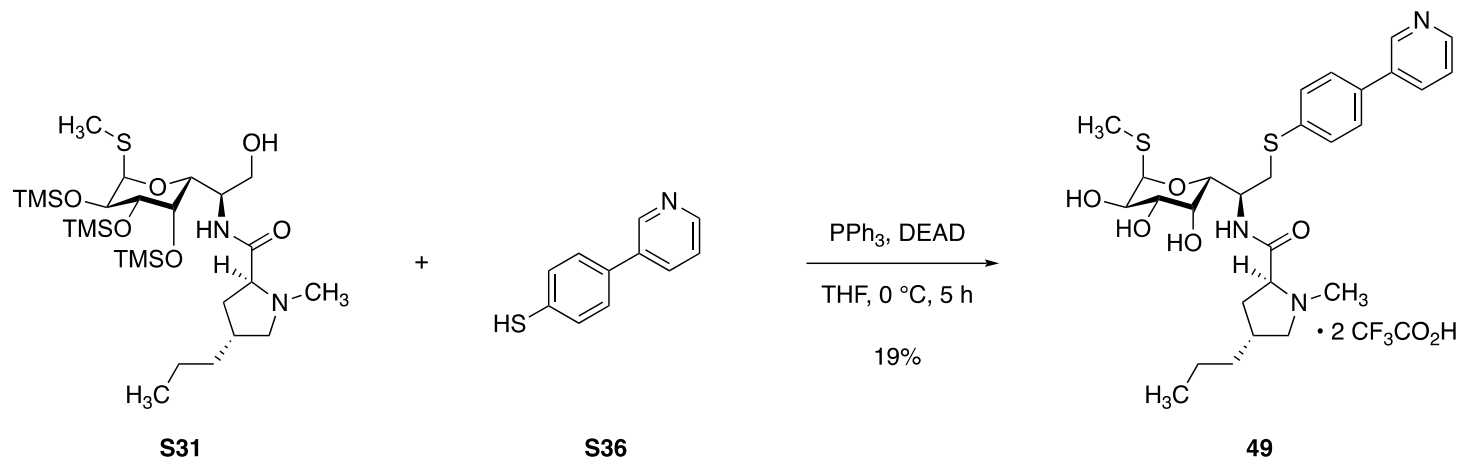

\section{Synthetic lincosamide 49.}

In a 1-mL glass vial, 2,3,4-tris- $O$-trimethylsilyl-8-norlincomycin $(\mathbf{S 3 1}, 20 \mathrm{mg}, 33 \mu \mathrm{mol}, 1$ equiv) and triphenylphosphine (17 mg, $66 \mu \mathrm{mol}, 2.0$ equiv) were dissolved in tetrahydrofuran (660 $\mu \mathrm{L}$ ), and the resulting solution was chilled to $0{ }^{\circ} \mathrm{C}$. With constant stirring, diethyl azodicarboxylate solution (40\% w/w in toluene, $30 \mu \mathrm{L}, 66 \mu \mathrm{mol}, 2.0$ equiv) was added dropwise, and the mixture was stirred at $0{ }^{\circ} \mathrm{C}$ for $5 \mathrm{~min}$, during which time the original orange color of the azodicarboxylate reagent faded to afford a colorless reaction mixture. 4-(Pyridin-3-yl)benzenethiol (S36, 15 mg, 82 $\mu$ mol, 2.5 equiv) was added next, resulting in a flash of yellow-orange color that then disappeared. Progress was monitored by LCMS, and after $5 \mathrm{~h}$, the reaction was judged to be complete. The mixture was concentrated to dryness under a stream of nitrogen, and the residue was then redissolved in $50 \% \mathrm{v} / \mathrm{v}$ methanol-1N aqueous hydrogen chloride solution $(800 \mu \mathrm{L})$. After 30 min of stirring at $23{ }^{\circ} \mathrm{C}$, LCMS analysis showed that global desilylation was complete, and the mixture was passed through a $0.2-\mu \mathrm{m}$ PTFE filter. The filtrate was concentrated, and the crude residue was subjected to preparative HPLC on a on a Waters SunFire Prep $\mathrm{C}_{18}$ column $(5 \mu \mathrm{m}, 250 \times 19 \mathrm{~mm}$; eluting with $0.1 \%$ trifluoroacetic acid-water, grading to $0.1 \%$ trifluoroacetic acid-40\% acetonitrile-water over $40 \mathrm{~min}$, with a flow rate of $15 \mathrm{~mL} / \mathrm{min}$; monitored by UV absorbance at $254 \mathrm{~nm} ; \mathrm{R}_{t}=27.8 \mathrm{~min}$ ) to provide arenesulfide analog $49 \cdot 2 \mathrm{CF}_{3} \mathrm{CO}_{2} \mathrm{H}$ as a white solid (4.8 $\mathrm{mg}$, $19 \%)$. 
${ }^{1} \mathrm{H}$ NMR $\left(600 \mathrm{MHz}, \mathrm{CD}_{3} \mathrm{OD}\right) \delta 9.09(\mathrm{~s}, 1 \mathrm{H}), 8.75(\mathrm{~d}, J=4.9 \mathrm{~Hz}, 1 \mathrm{H}), 8.70(\mathrm{~d}, J=8.2 \mathrm{~Hz}, 1 \mathrm{H})$, $8.00(\mathrm{dd}, J=8.2,5.4 \mathrm{~Hz}, 1 \mathrm{H}), 7.75(\mathrm{~d}, J=8.5 \mathrm{~Hz}, 2 \mathrm{H}), 7.54(\mathrm{~d}, J=8.5 \mathrm{~Hz}, 2 \mathrm{H}), 5.33(\mathrm{~d}, J$ $=5.6 \mathrm{~Hz}, 1 \mathrm{H}), 4.50($ app td, $J=9.0,3.4 \mathrm{~Hz}, 1 \mathrm{H}), 4.24(\mathrm{dd}, J=8.8,1.3 \mathrm{~Hz}, 1 \mathrm{H}), 4.16(\mathrm{dd}$, $J=9.8,6.3 \mathrm{~Hz}, 1 \mathrm{H}), 4.11(\mathrm{dd}, J=10.1,5.6 \mathrm{~Hz}, 1 \mathrm{H}), 3.90(\mathrm{dd}, J=3.4,1.2 \mathrm{~Hz}, 1 \mathrm{H}), 3.74$ (dd, $J=11.1,6.8 \mathrm{~Hz}, 1 \mathrm{H}), 3.70(\mathrm{dd}, J=14.0,3.5 \mathrm{~Hz}, 1 \mathrm{H}), 3.60(\mathrm{dd}, J=10.1,3.3 \mathrm{~Hz}, 1 \mathrm{H})$, $3.14(\mathrm{dd}, J=14.0,9.2 \mathrm{~Hz}, 1 \mathrm{H}), 2.92(\mathrm{~s}, 3 \mathrm{H}), 2.86(\mathrm{app} t, J=11.1 \mathrm{~Hz}, 1 \mathrm{H}), 2.34-2.26(\mathrm{~m}$, 1H), 2.22-2.15 (m, 2H), $2.11(\mathrm{~s}, 3 \mathrm{H}), 1.46-1.39(\mathrm{~m}, 2 \mathrm{H}), 1.33-1.28(\mathrm{~m}, 2 \mathrm{H}), 0.90(\mathrm{t}, J=$ $7.3 \mathrm{~Hz}, 3 \mathrm{H})$.

HRMS (ESI,$+ m / z):[\mathrm{M}+2 \mathrm{H}]^{2+}$ calc'd for $\mathrm{C}_{28} \mathrm{H}_{39} \mathrm{~N}_{3} \mathrm{O}_{5} \mathrm{~S}_{2}, 281.6238$; found 281.6238 . 

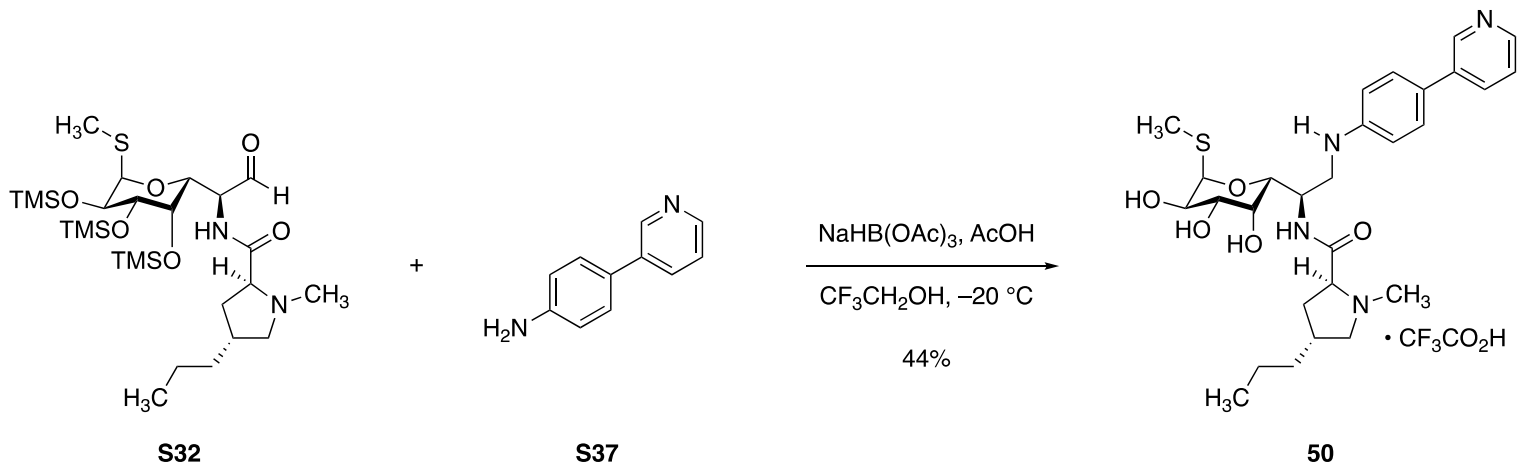

\section{Synthetic lincosamide 50.}

A 4-mL glass vial fitted with a PTFE-lined screw cap was charged with a magnetic stir bar, aldehyde S32 (theoretically $10 \mathrm{mg}, 16 \mu \mathrm{mol}, 1$ equiv), 2,2,2-trifluoroethanol $(330 \mu \mathrm{L})$, and powdered, activated $4 \AA$ molecular sieves $(10 \mathrm{mg})$. The suspension was chilled to $-20{ }^{\circ} \mathrm{C}$ in an acetone bath, whereupon acetic acid $(5.7 \mu \mathrm{L}, 99 \mu \mathrm{mol}, 6.0$ equiv) was added. 4-(Pyridin-3yl)aniline (S37, $8.4 \mathrm{mg}, 49 \mu \mathrm{mol}, 3.0$ equiv) was added next, causing the mixture to turn tennisball yellow; and the mixture was stirred at $-20^{\circ} \mathrm{C}$ for $15 \mathrm{~min}$ before the mixture was treated with sodium triacetoxyborohydride ( $10 \mathrm{mg}, 49 \mu \mathrm{mol}, 3.0$ equiv). After $30 \mathrm{~min}$, LCMS analysis showed complete consumption of aldehyde starting material and imine intermediate. The mixture was warmed to $23{ }^{\circ} \mathrm{C}$ and was concentrated to dryness before being re-suspended in $50 \% \mathrm{v} / \mathrm{v}$ methanol$1 \mathrm{~N}$ aqueous hydrogen chloride solution. After $5 \mathrm{~min}$ of stirring at $23^{\circ} \mathrm{C}$, LCMS analysis showed that global desilylation was complete, and the yellow mixture was filtered through a $0.2-\mu \mathrm{m}$ PTFE filter. The filtrate was concentrated, and the crude residue was purified by preparative HPLC on a Waters SunFire Prep $\mathrm{C}_{18}$ column $(5 \mu \mathrm{m}, 250 \times 19 \mathrm{~mm}$; eluting with $0.1 \%$ trifluoroacetic acidwater, grading to $0.1 \%$ trifluoroacetic acid-50\% acetonitrile-water over $40 \mathrm{~min}$, with a flow rate of $15 \mathrm{~mL} / \mathrm{min}$; monitored by UV absorbance at $280 \mathrm{~nm} ; \mathrm{R}_{t}=22.2 \mathrm{~min}$ ) to provide (pyridyl)aniline analog $\mathbf{5 0} \cdot \mathrm{CF}_{3} \mathrm{CO}_{2} \mathrm{H}$ as a white solid $(5.6 \mathrm{mg}, 44 \%, 2$ steps). 
${ }^{1} \mathrm{H}\left(500 \mathrm{MHz}, \mathrm{CD}_{3} \mathrm{OD}\right) \delta 9.03(\mathrm{~d}, J=2.1 \mathrm{~Hz}, 1 \mathrm{H}), 8.77(\mathrm{ddd}, J=8.4,2.3,1.3 \mathrm{~Hz}, 1 \mathrm{H}), 8.62(\mathrm{dd}$, $J=5.6,1.1 \mathrm{~Hz}, 1 \mathrm{H}), 8.03(\mathrm{dd}, J=8.3,5.6 \mathrm{~Hz}, 1 \mathrm{H}), 7.63(\mathrm{~d}, J=8.7 \mathrm{~Hz}, 2 \mathrm{H}), 6.82(\mathrm{~d}, J=$ $8.7 \mathrm{~Hz}, 2 \mathrm{H}), 5.35(\mathrm{~d}, J=5.6 \mathrm{~Hz}, 1 \mathrm{H}), 4.50(\operatorname{app} \mathrm{td}, J=9.1,3.9 \mathrm{~Hz}, 1 \mathrm{H}), 4.25(\mathrm{~d}, J=8.9$ $\mathrm{Hz}, 1 \mathrm{H}), 4.16-4.11(\mathrm{~m}, 2 \mathrm{H}), 3.91(\mathrm{dd}, J=3.3,1.1 \mathrm{~Hz}, 1 \mathrm{H}), 3.72-3.66$ (m, 2H), 3.62 (dd, $J$ $=10.1,3.3 \mathrm{~Hz}, 1 \mathrm{H}), 3.37(\mathrm{dd}, J=14.1,9.3 \mathrm{~Hz}, 1 \mathrm{H}), 2.91(\mathrm{~s}, 3 \mathrm{H}), 2.83($ app t, $J=11.0 \mathrm{~Hz}$, $1 \mathrm{H}), 2.23-2.16(\mathrm{~m}, 1 \mathrm{H}), 2.09(\mathrm{~s}, 3 \mathrm{H}), 2.09-2.00(\mathrm{~m}, 2 \mathrm{H}), 1.43-1.30(\mathrm{~m}, 2 \mathrm{H}), 1.27-1.19$ (m, 2H), $0.84(\mathrm{t}, J=7.2 \mathrm{~Hz}, 3 \mathrm{H})$.

HRMS (ESI+, $m / z)$ : $[\mathrm{M}+2 \mathrm{H}]^{2+}$ calc'd for $\mathrm{C}_{28} \mathrm{H}_{40} \mathrm{~N}_{4} \mathrm{O}_{5} \mathrm{~S}, 273.1432$; found 273.1432 . 


\section{Catalog of X-ray Crystal Structures}

X-Ray Crystallography: Data were collected from a crystal mounted on a diffractometer at $100 \mathrm{~K}$. The intensities of the reflections were collected using a Bruker APEX II DUO CCD diffractometer ( $\mathrm{Cu}_{\alpha}$ radiation, $\lambda=1.54178 \AA$ ) equipped with an Oxford Cryosystems nitrogenflow apparatus. The collection method involved $1.0^{\circ}$ scans in $\omega$ at $-30^{\circ},-55^{\circ},-80^{\circ}, 30^{\circ}, 55^{\circ}, 80^{\circ}$ and $115^{\circ}$ in $2 \theta$. Data integration down to 0.84 - $\AA$ resolution was carried out using SAINT V8.34 C with reflection spot size optimization. Absorption corrections were made with the program SADABS. ${ }^{32}$ The structure was solved by the intrinsic-phasing method and was refined against $F^{2}$ by least-squares using SHELXT-2014 and SHELXL-2014 ${ }^{33}$ through the OLEX 2 interface. Nonhydrogen atoms were refined anisotropically. Hydrogen atoms were placed at idealized positions and were refined using a riding model. Crystal data as well as details of data collection and refinement are summarized in Tables S1, S4, and S7; geometric parameters are shown in Tables S2, S5, and S8; and hydrogen-bond geometric parameters are listed in Tables S3, S6, and S9. The Ortep plots produced with SHELXL-2014 program, and the other drawings were produced with Accelrys DS Visualizer 2.0. ${ }^{34}$

\footnotetext{
${ }^{32}$ Bruker AXS APEX3, Bruker AXS, Madison, Wisconsin, 2015.

${ }^{33}$ Sheldrick, G. M. Acta Cryst. 2015, A71, 3-8. Sheldrick, G. M. Acta Cryst. 2015, C21, 3-8.

${ }^{34}$ Accelrys DS Visualizer v2.0.1, Accelrys Software, Inc., 2007.
} 


\section{Crystallographic Data for Compound 17}

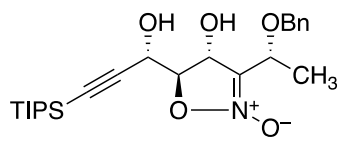

17

\section{Table S1. Experimental details}

\begin{tabular}{|c|c|}
\hline \multicolumn{2}{|l|}{ CCDC Deposition Number 2072279} \\
\hline Chemical formula & $\mathrm{C}_{24} \mathrm{H}_{37} \mathrm{NO}_{5} \mathrm{Si}$ \\
\hline$M_{\mathrm{r}}$ & 447.63 \\
\hline Crystal system, space group & Monoclinic, $P 2_{1}$ \\
\hline Temperature $(\mathrm{K})$ & 100 \\
\hline$a, b, c(\AA)$ & $11.7798(16), 6.7133(10), 19.712(3)$ \\
\hline$\beta\left(^{\circ}\right)$ & $103.006(7)$ \\
\hline$V\left(\AA^{3}\right)$ & $1518.8(4)$ \\
\hline$Z$ & 2 \\
\hline Radiation type & $\mathrm{Cu} K \alpha$ \\
\hline$\mu\left(\mathrm{mm}^{-1}\right)$ & 0.90 \\
\hline Crystal size (mm) & $0.12 \times 0.01 \times 0.01$ \\
\hline \multicolumn{2}{|l|}{ Data collection } \\
\hline Diffractometer & Bruker D8 goniometer with CCD area detector diffractometer \\
\hline Absorption correction & $\begin{array}{l}\text { Multi-scan } \\
S A D A B S\end{array}$ \\
\hline$T_{\min }, T_{\max }$ & $0.683,0.864$ \\
\hline $\begin{array}{l}\text { No. of measured, independent and } \\
\text { observed }[I>2 \sigma(I)] \text { reflections }\end{array}$ & $22195,4853,3617$ \\
\hline$R_{\text {int }}$ & 0.109 \\
\hline$(\sin \theta / \lambda)_{\max }\left(\AA^{-1}\right)$ & 0.596 \\
\hline \multicolumn{2}{|l|}{ Refinement } \\
\hline$R\left[F^{2}>2 \sigma\left(F^{2}\right)\right], w R\left(F^{2}\right), S$ & $0.084,0.231,1.04$ \\
\hline No. of reflections & 4853 \\
\hline No. of parameters & 314 \\
\hline No. of restraints & 85 \\
\hline H-atom treatment & H-atom parameters constrained \\
\hline
\end{tabular}


Table S1 (Continued)

\begin{tabular}{|l|l|}
\hline$\Delta \rho_{\max }, \Delta \rho_{\min }\left(\mathrm{e} \AA^{-3}\right)$ & $0.49,-0.26$ \\
\hline Absolute structure & $\begin{array}{l}\text { Flack x determined using } 1118 \text { quotients [(I+)-(I-)]/[(I+)+(I-)] (Parsons, } \\
\text { Flack and Wagner, Acta Cryst. B69 (2013) 249-259). }\end{array}$ \\
\hline Absolute structure parameter & $0.05(5)$ \\
\hline
\end{tabular}

Computer programs: APEX3 v2015.5.2 (Bruker-AXS, 2015), SAINT 8.34C (Bruker-AXS, 2014), SHELXT2014 (Sheldrick, 2015), SHELXL2014 (Sheldrick, 2015), Bruker SHELXTL (Sheldrick, 2015).

Table S2. Geometric parameters $\left(\stackrel{\AA}{\AA}{ }^{\circ}\right)$

\begin{tabular}{|c|c|c|c|}
\hline $\mathrm{C} 1-\mathrm{C} 6$ & $1.361(10)$ & $\mathrm{C} 20-\mathrm{H} 20 \mathrm{~A}$ & 0.9800 \\
\hline $\mathrm{C} 1-\mathrm{C} 2$ & $1.385(10)$ & $\mathrm{C} 20-\mathrm{H} 20 \mathrm{~B}$ & 0.9800 \\
\hline $\mathrm{C} 1-\mathrm{H} 1$ & 0.9500 & $\mathrm{C} 20-\mathrm{H} 20 \mathrm{C}$ & 0.9800 \\
\hline $\mathrm{C} 2-\mathrm{C} 3$ & $1.374(13)$ & $\mathrm{C} 21-\mathrm{H} 21 \mathrm{~A}$ & 0.9800 \\
\hline $\mathrm{C} 2-\mathrm{H} 2$ & 0.9500 & $\mathrm{C} 21-\mathrm{H} 21 \mathrm{~B}$ & 0.9800 \\
\hline $\mathrm{C} 3-\mathrm{C} 4$ & $1.392(14)$ & $\mathrm{C} 21-\mathrm{H} 21 \mathrm{C}$ & 0.9800 \\
\hline $\mathrm{C} 3-\mathrm{H} 3$ & 0.9500 & $\mathrm{C} 22-\mathrm{C} 24$ & $1.50(2)$ \\
\hline $\mathrm{C} 4-\mathrm{C} 5$ & $1.370(10)$ & $\mathrm{C} 22-\mathrm{C} 23$ & $1.57(2)$ \\
\hline $\mathrm{C} 4-\mathrm{H} 4$ & 0.9500 & $\mathrm{C} 22-\mathrm{H} 22$ & 1.0000 \\
\hline $\mathrm{C} 5-\mathrm{C} 6$ & $1.392(11)$ & $\mathrm{C} 23-\mathrm{H} 23 \mathrm{~A}$ & 0.9800 \\
\hline $\mathrm{C} 5-\mathrm{H} 5$ & 0.9500 & C23-H23B & 0.9800 \\
\hline $\mathrm{C} 6-\mathrm{C} 7$ & $1.506(8)$ & $\mathrm{C} 23-\mathrm{H} 23 \mathrm{C}$ & 0.9800 \\
\hline $\mathrm{C} 7-\mathrm{O} 1$ & $1.430(9)$ & $\mathrm{C} 24-\mathrm{H} 24 \mathrm{~A}$ & 0.9800 \\
\hline $\mathrm{C} 7-\mathrm{H} 7 \mathrm{~A}$ & 0.9900 & $\mathrm{C} 24-\mathrm{H} 24 \mathrm{~B}$ & 0.9800 \\
\hline C7-H7B & 0.9900 & $\mathrm{C} 24-\mathrm{H} 24 \mathrm{C}$ & 0.9800 \\
\hline $\mathrm{C} 8-\mathrm{O} 1$ & $1.416(7)$ & $\mathrm{C} 14 \mathrm{~A}-\mathrm{C} 15 \mathrm{~A}$ & $1.248(19)$ \\
\hline $\mathrm{C} 8-\mathrm{C} 10$ & $1.495(9)$ & $\mathrm{C} 15 \mathrm{~A}-\mathrm{Si} 1 \mathrm{~A}$ & $1.90(2)$ \\
\hline $\mathrm{C} 8-\mathrm{C} 9$ & $1.510(10)$ & Si1A-C16A & $1.82(2)$ \\
\hline $\mathrm{C} 8-\mathrm{H} 8$ & 1.0000 & $\mathrm{Si} 1 \mathrm{~A}-\mathrm{C} 22 \mathrm{~A}$ & $1.94(2)$ \\
\hline C9-H9A & 0.9800 & Si1A $-\mathrm{C} 19 \mathrm{~A}$ & $1.96(3)$ \\
\hline C9-H9B & 0.9800 & $\mathrm{C} 16 \mathrm{~A}-\mathrm{C} 18 \mathrm{~A}$ & $1.53(3)$ \\
\hline C9- $\mathrm{H} 9 \mathrm{C}$ & 0.9800 & $\mathrm{C} 16 \mathrm{~A}-\mathrm{C} 17 \mathrm{~A}$ & $1.61(3)$ \\
\hline $\mathrm{C} 10-\mathrm{N} 1$ & $1.312(8)$ & $\mathrm{C} 16 \mathrm{~A}-\mathrm{H} 16 \mathrm{~A}$ & 1.0000 \\
\hline $\mathrm{C} 10-\mathrm{C} 11$ & $1.504(9)$ & C17A-H17D & 0.9800 \\
\hline
\end{tabular}


Table S2 (Continued)

\begin{tabular}{|c|c|c|c|}
\hline $\mathrm{C} 11-\mathrm{O} 4$ & $1.413(8)$ & $\mathrm{C} 17 \mathrm{~A}-\mathrm{H} 17 \mathrm{E}$ & 0.9800 \\
\hline $\mathrm{C} 11-\mathrm{C} 12$ & $1.555(9)$ & $\mathrm{C} 17 \mathrm{~A}-\mathrm{H} 17 \mathrm{~F}$ & 0.9800 \\
\hline $\mathrm{C} 11-\mathrm{H} 11$ & 1.0000 & $\mathrm{C} 18 \mathrm{~A}-\mathrm{H} 18 \mathrm{D}$ & 0.9800 \\
\hline $\mathrm{C} 12-\mathrm{O} 2$ & $1.451(7)$ & C18A-H18E & 0.9800 \\
\hline $\mathrm{C} 12-\mathrm{C} 13$ & $1.510(9)$ & $\mathrm{C} 18 \mathrm{~A}-\mathrm{H} 18 \mathrm{~F}$ & 0.9800 \\
\hline $\mathrm{C} 12-\mathrm{H} 12$ & 1.0000 & $\mathrm{C} 19 \mathrm{~A}-\mathrm{C} 20 \mathrm{~A}$ & $1.36(3)$ \\
\hline $\mathrm{C} 13-\mathrm{O} 5$ & $1.422(8)$ & $\mathrm{C} 19 \mathrm{~A}-\mathrm{C} 21 \mathrm{~A}$ & $1.47(3)$ \\
\hline $\mathrm{C} 13-\mathrm{C} 14 \mathrm{~A}$ & $1.475(9)$ & C19A-H19A & 1.0000 \\
\hline $\mathrm{C} 13-\mathrm{C} 14$ & $1.475(9)$ & $\mathrm{C} 20 \mathrm{~A}-\mathrm{H} 20 \mathrm{D}$ & 0.9800 \\
\hline C13-H13 & 1.0000 & $\mathrm{C} 20 \mathrm{~A}-\mathrm{H} 20 \mathrm{E}$ & 0.9800 \\
\hline C13-H13A & 1.0000 & $\mathrm{C} 20 \mathrm{~A}-\mathrm{H} 20 \mathrm{~F}$ & 0.9800 \\
\hline $\mathrm{C} 14-\mathrm{C} 15$ & 1.199 (12) & $\mathrm{C} 21 \mathrm{~A}-\mathrm{H} 21 \mathrm{D}$ & 0.9800 \\
\hline $\mathrm{C} 15-\mathrm{Si} 1$ & $1.851(13)$ & $\mathrm{C} 21 \mathrm{~A}-\mathrm{H} 21 \mathrm{E}$ & 0.9800 \\
\hline $\mathrm{Si} 1-\mathrm{C} 16$ & $1.854(12)$ & $\mathrm{C} 21 \mathrm{~A}-\mathrm{H} 21 \mathrm{~F}$ & 0.9800 \\
\hline $\mathrm{Si} 1-\mathrm{C} 19$ & $1.881(16)$ & $\mathrm{C} 22 \mathrm{~A}-\mathrm{C} 24 \mathrm{~A}$ & $1.49(3)$ \\
\hline $\mathrm{Si} 1-\mathrm{C} 22$ & $1.931(17)$ & $\mathrm{C} 22 \mathrm{~A}-\mathrm{C} 23 \mathrm{~A}$ & $1.59(3)$ \\
\hline $\mathrm{C} 16-\mathrm{C} 18$ & $1.560(17)$ & $\mathrm{C} 22 \mathrm{~A}-\mathrm{H} 22 \mathrm{~A}$ & 1.0000 \\
\hline $\mathrm{C} 16-\mathrm{C} 17$ & $1.61(2)$ & $\mathrm{C} 23 \mathrm{~A}-\mathrm{H} 23 \mathrm{D}$ & 0.9800 \\
\hline $\mathrm{C} 16-\mathrm{H} 16$ & 1.0000 & $\mathrm{C} 23 \mathrm{~A}-\mathrm{H} 23 \mathrm{E}$ & 0.9800 \\
\hline C17-H17A & 0.9800 & $\mathrm{C} 23 \mathrm{~A}-\mathrm{H} 23 \mathrm{~F}$ & 0.9800 \\
\hline C17-H17B & 0.9800 & $\mathrm{C} 24 \mathrm{~A}-\mathrm{H} 24 \mathrm{D}$ & 0.9800 \\
\hline C17-H17C & 0.9800 & $\mathrm{C} 24 \mathrm{~A}-\mathrm{H} 24 \mathrm{E}$ & 0.9800 \\
\hline $\mathrm{C} 18-\mathrm{H} 18 \mathrm{~A}$ & 0.9800 & $\mathrm{C} 24 \mathrm{~A}-\mathrm{H} 24 \mathrm{~F}$ & 0.9800 \\
\hline $\mathrm{C} 18-\mathrm{H} 18 \mathrm{~B}$ & 0.9800 & $\mathrm{~N} 1-\mathrm{O} 3$ & $1.261(7)$ \\
\hline $\mathrm{C} 18-\mathrm{H} 18 \mathrm{C}$ & 0.9800 & $\mathrm{~N} 1-\mathrm{O} 2$ & $1.424(7)$ \\
\hline $\mathrm{C} 19-\mathrm{C} 20$ & $1.36(2)$ & $\mathrm{O} 4-\mathrm{H} 4 \mathrm{~A}$ & 0.8400 \\
\hline $\mathrm{C} 19-\mathrm{C} 21$ & $1.50(2)$ & $\mathrm{O} 5-\mathrm{H} 5 \mathrm{~A}$ & 0.8400 \\
\hline $\mathrm{C} 19-\mathrm{H} 19$ & 1.0000 & & \\
\hline $\mathrm{C} 6-\mathrm{C} 1-\mathrm{C} 2$ & $122.8(8)$ & $\mathrm{C} 19-\mathrm{C} 20-\mathrm{H} 20 \mathrm{C}$ & 109.5 \\
\hline $\mathrm{C} 6-\mathrm{C} 1-\mathrm{H} 1$ & 118.6 & $\mathrm{H} 20 \mathrm{~A}-\mathrm{C} 20-\mathrm{H} 20 \mathrm{C}$ & 109.5 \\
\hline $\mathrm{C} 2-\mathrm{C} 1-\mathrm{H} 1$ & 118.6 & $\mathrm{H} 20 \mathrm{~B}-\mathrm{C} 20-\mathrm{H} 20 \mathrm{C}$ & 109.5 \\
\hline $\mathrm{C} 3-\mathrm{C} 2-\mathrm{C} 1$ & $117.8(7)$ & $\mathrm{C} 19-\mathrm{C} 21-\mathrm{H} 21 \mathrm{~A}$ & 109.5 \\
\hline $\mathrm{C} 3-\mathrm{C} 2-\mathrm{H} 2$ & 121.1 & $\mathrm{C} 19-\mathrm{C} 21-\mathrm{H} 21 \mathrm{~B}$ & 109.5 \\
\hline $\mathrm{C} 1-\mathrm{C} 2-\mathrm{H} 2$ & 121.1 & $\mathrm{H} 21 \mathrm{~A}-\mathrm{C} 21-\mathrm{H} 21 \mathrm{~B}$ & 109.5 \\
\hline
\end{tabular}




\begin{tabular}{|c|c|c|c|}
\hline $\mathrm{C} 2-\mathrm{C} 3-\mathrm{C} 4$ & $121.5(7)$ & $\mathrm{C} 19-\mathrm{C} 21-\mathrm{H} 21 \mathrm{C}$ & 109.5 \\
\hline $\mathrm{C} 2-\mathrm{C} 3-\mathrm{H} 3$ & 119.2 & $\mathrm{H} 21 \mathrm{~A}-\mathrm{C} 21-\mathrm{H} 21 \mathrm{C}$ & 109.5 \\
\hline $\mathrm{C} 4-\mathrm{C} 3-\mathrm{H} 3$ & 119.2 & $\mathrm{H} 21 \mathrm{~B}-\mathrm{C} 21-\mathrm{H} 21 \mathrm{C}$ & 109.5 \\
\hline $\mathrm{C} 5-\mathrm{C} 4-\mathrm{C} 3$ & $118.3(9)$ & $\mathrm{C} 24-\mathrm{C} 22-\mathrm{C} 23$ & $111.7(18)$ \\
\hline $\mathrm{C} 5-\mathrm{C} 4-\mathrm{H} 4$ & 120.9 & $\mathrm{C} 24-\mathrm{C} 22-\mathrm{Si} 1$ & $116.5(14)$ \\
\hline $\mathrm{C} 3-\mathrm{C} 4-\mathrm{H} 4$ & 120.9 & $\mathrm{C} 23-\mathrm{C} 22-\mathrm{Si} 1$ & $106.8(13)$ \\
\hline $\mathrm{C} 4-\mathrm{C} 5-\mathrm{C} 6$ & $121.9(8)$ & $\mathrm{C} 24-\mathrm{C} 22-\mathrm{H} 22$ & 107.1 \\
\hline $\mathrm{C} 4-\mathrm{C} 5-\mathrm{H} 5$ & 119.1 & $\mathrm{C} 23-\mathrm{C} 22-\mathrm{H} 22$ & 107.1 \\
\hline $\mathrm{C} 6-\mathrm{C} 5-\mathrm{H} 5$ & 119.1 & $\mathrm{Si} 1-\mathrm{C} 22-\mathrm{H} 22$ & 107.1 \\
\hline $\mathrm{C} 1-\mathrm{C} 6-\mathrm{C} 5$ & $117.7(6)$ & $\mathrm{C} 22-\mathrm{C} 23-\mathrm{H} 23 \mathrm{~A}$ & 109.5 \\
\hline $\mathrm{C} 1-\mathrm{C} 6-\mathrm{C} 7$ & $123.6(7)$ & $\mathrm{C} 22-\mathrm{C} 23-\mathrm{H} 23 \mathrm{~B}$ & 109.5 \\
\hline $\mathrm{C} 5-\mathrm{C} 6-\mathrm{C} 7$ & $118.6(6)$ & $\mathrm{H} 23 \mathrm{~A}-\mathrm{C} 23-\mathrm{H} 23 \mathrm{~B}$ & 109.5 \\
\hline $\mathrm{O} 1-\mathrm{C} 7-\mathrm{C} 6$ & $108.4(5)$ & $\mathrm{C} 22-\mathrm{C} 23-\mathrm{H} 23 \mathrm{C}$ & 109.5 \\
\hline $\mathrm{O} 1-\mathrm{C} 7-\mathrm{H} 7 \mathrm{~A}$ & 110.0 & $\mathrm{H} 23 \mathrm{~A}-\mathrm{C} 23-\mathrm{H} 23 \mathrm{C}$ & 109.5 \\
\hline $\mathrm{C} 6-\mathrm{C} 7-\mathrm{H} 7 \mathrm{~A}$ & 110.0 & $\mathrm{H} 23 \mathrm{~B}-\mathrm{C} 23-\mathrm{H} 23 \mathrm{C}$ & 109.5 \\
\hline $\mathrm{O} 1-\mathrm{C} 7-\mathrm{H} 7 \mathrm{~B}$ & 110.0 & $\mathrm{C} 22-\mathrm{C} 24-\mathrm{H} 24 \mathrm{~A}$ & 109.5 \\
\hline $\mathrm{C} 6-\mathrm{C} 7-\mathrm{H} 7 \mathrm{~B}$ & 110.0 & $\mathrm{C} 22-\mathrm{C} 24-\mathrm{H} 24 \mathrm{~B}$ & 109.5 \\
\hline $\mathrm{H} 7 \mathrm{~A}-\mathrm{C} 7-\mathrm{H} 7 \mathrm{~B}$ & 108.4 & $\mathrm{H} 24 \mathrm{~A}-\mathrm{C} 24-\mathrm{H} 24 \mathrm{~B}$ & 109.5 \\
\hline $\mathrm{O} 1-\mathrm{C} 8-\mathrm{C} 10$ & $111.2(6)$ & $\mathrm{C} 22-\mathrm{C} 24-\mathrm{H} 24 \mathrm{C}$ & 109.5 \\
\hline $\mathrm{O} 1-\mathrm{C} 8-\mathrm{C} 9$ & $106.4(5)$ & $\mathrm{H} 24 \mathrm{~A}-\mathrm{C} 24-\mathrm{H} 24 \mathrm{C}$ & 109.5 \\
\hline $\mathrm{C} 10-\mathrm{C} 8-\mathrm{C} 9$ & $113.4(6)$ & $\mathrm{H} 24 \mathrm{~B}-\mathrm{C} 24-\mathrm{H} 24 \mathrm{C}$ & 109.5 \\
\hline $\mathrm{O} 1-\mathrm{C} 8-\mathrm{H} 8$ & 108.6 & $\mathrm{C} 15 \mathrm{~A}-\mathrm{C} 14 \mathrm{~A}-\mathrm{C} 13$ & $170(4)$ \\
\hline $\mathrm{C} 10-\mathrm{C} 8-\mathrm{H} 8$ & 108.6 & $\mathrm{C} 14 \mathrm{~A}-\mathrm{C} 15 \mathrm{~A}-\mathrm{Si} 1 \mathrm{~A}$ & $172(7)$ \\
\hline $\mathrm{C} 9-\mathrm{C} 8-\mathrm{H} 8$ & 108.6 & $\mathrm{C} 16 \mathrm{~A}-\mathrm{Si} 1 \mathrm{~A}-\mathrm{C} 15 \mathrm{~A}$ & $110(2)$ \\
\hline $\mathrm{C} 8-\mathrm{C} 9-\mathrm{H} 9 \mathrm{~A}$ & 109.5 & $\mathrm{C} 16 \mathrm{~A}-\mathrm{Si} 1 \mathrm{~A}-\mathrm{C} 22 \mathrm{~A}$ & $125.3(15)$ \\
\hline $\mathrm{C} 8-\mathrm{C} 9-\mathrm{H} 9 \mathrm{~B}$ & 109.5 & $\mathrm{C} 15 \mathrm{~A}-\mathrm{Si} 1 \mathrm{~A}-\mathrm{C} 22 \mathrm{~A}$ & $109(3)$ \\
\hline $\mathrm{H} 9 \mathrm{~A}-\mathrm{C} 9-\mathrm{H} 9 \mathrm{~B}$ & 109.5 & $\mathrm{C} 16 \mathrm{~A}-\mathrm{Si1A}-\mathrm{C} 19 \mathrm{~A}$ & $112.3(16)$ \\
\hline $\mathrm{C} 8-\mathrm{C} 9-\mathrm{H} 9 \mathrm{C}$ & 109.5 & $\mathrm{C} 15 \mathrm{~A}-\mathrm{Si} 1 \mathrm{~A}-\mathrm{C} 19 \mathrm{~A}$ & $106(3)$ \\
\hline $\mathrm{H} 9 \mathrm{~A}-\mathrm{C} 9-\mathrm{H} 9 \mathrm{C}$ & 109.5 & $\mathrm{C} 22 \mathrm{~A}-\mathrm{Si1A}-\mathrm{C} 19 \mathrm{~A}$ & $90.8(17)$ \\
\hline $\mathrm{H} 9 \mathrm{~B}-\mathrm{C} 9-\mathrm{H} 9 \mathrm{C}$ & 109.5 & $\mathrm{C} 18 \mathrm{~A}-\mathrm{C} 16 \mathrm{~A}-\mathrm{C} 17 \mathrm{~A}$ & $115(2)$ \\
\hline $\mathrm{N} 1-\mathrm{C} 10-\mathrm{C} 8$ & $121.0(6)$ & $\mathrm{C} 18 \mathrm{~A}-\mathrm{C} 16 \mathrm{~A}-\mathrm{Si} 1 \mathrm{~A}$ & $102(2)$ \\
\hline $\mathrm{N} 1-\mathrm{C} 10-\mathrm{C} 11$ & $109.4(5)$ & $\mathrm{C} 17 \mathrm{~A}-\mathrm{C} 16 \mathrm{~A}-\mathrm{Si} 1 \mathrm{~A}$ & $113(2)$ \\
\hline $\mathrm{C} 8-\mathrm{C} 10-\mathrm{C} 11$ & $129.6(5)$ & $\mathrm{C} 18 \mathrm{~A}-\mathrm{C} 16 \mathrm{~A}-\mathrm{H} 16 \mathrm{~A}$ & 108.7 \\
\hline $\mathrm{O} 4-\mathrm{C} 11-\mathrm{C} 10$ & $113.5(5)$ & $\mathrm{C} 17 \mathrm{~A}-\mathrm{C} 16 \mathrm{~A}-\mathrm{H} 16 \mathrm{~A}$ & 108.7 \\
\hline $\mathrm{O} 4-\mathrm{C} 11-\mathrm{C} 12$ & $113.2(5)$ & Si1A $-\mathrm{C} 16 \mathrm{~A}-\mathrm{H} 16 \mathrm{~A}$ & 108.7 \\
\hline $\mathrm{C} 10-\mathrm{C} 11-\mathrm{C} 12$ & $103.2(5)$ & $\mathrm{C} 16 \mathrm{~A}-\mathrm{C} 17 \mathrm{~A}-\mathrm{H} 17 \mathrm{D}$ & 109.5 \\
\hline $\mathrm{O} 4-\mathrm{C} 11-\mathrm{H} 11$ & 108.9 & $\mathrm{C} 16 \mathrm{~A}-\mathrm{C} 17 \mathrm{~A}-\mathrm{H} 17 \mathrm{E}$ & 109.5 \\
\hline
\end{tabular}


Table S2 (Continued)

\begin{tabular}{|c|c|c|c|}
\hline $\mathrm{C} 10-\mathrm{C} 11-\mathrm{H} 11$ & 108.9 & $\mathrm{H} 17 \mathrm{D}-\mathrm{C} 17 \mathrm{~A}-\mathrm{H} 17 \mathrm{E}$ & 109.5 \\
\hline $\mathrm{C} 12-\mathrm{C} 11-\mathrm{H} 11$ & 108.9 & $\mathrm{C} 16 \mathrm{~A}-\mathrm{C} 17 \mathrm{~A}-\mathrm{H} 17 \mathrm{~F}$ & 109.5 \\
\hline $\mathrm{O} 2-\mathrm{C} 12-\mathrm{C} 13$ & $108.6(5)$ & $\mathrm{H} 17 \mathrm{D}-\mathrm{C} 17 \mathrm{~A}-\mathrm{H} 17 \mathrm{~F}$ & 109.5 \\
\hline $\mathrm{O} 2-\mathrm{C} 12-\mathrm{C} 11$ & $105.6(5)$ & $\mathrm{H} 17 \mathrm{E}-\mathrm{C} 17 \mathrm{~A}-\mathrm{H} 17 \mathrm{~F}$ & 109.5 \\
\hline $\mathrm{C} 13-\mathrm{C} 12-\mathrm{C} 11$ & $114.4(5)$ & $\mathrm{C} 16 \mathrm{~A}-\mathrm{C} 18 \mathrm{~A}-\mathrm{H} 18 \mathrm{D}$ & 109.5 \\
\hline $\mathrm{O} 2-\mathrm{C} 12-\mathrm{H} 12$ & 109.3 & $\mathrm{C} 16 \mathrm{~A}-\mathrm{C} 18 \mathrm{~A}-\mathrm{H} 18 \mathrm{E}$ & 109.5 \\
\hline $\mathrm{C} 13-\mathrm{C} 12-\mathrm{H} 12$ & 109.3 & $\mathrm{H} 18 \mathrm{D}-\mathrm{C} 18 \mathrm{~A}-\mathrm{H} 18 \mathrm{E}$ & 109.5 \\
\hline $\mathrm{C} 11-\mathrm{C} 12-\mathrm{H} 12$ & 109.3 & $\mathrm{C} 16 \mathrm{~A}-\mathrm{C} 18 \mathrm{~A}-\mathrm{H} 18 \mathrm{~F}$ & 109.5 \\
\hline $\mathrm{O} 5-\mathrm{C} 13-\mathrm{C} 14 \mathrm{~A}$ & $111.8(5)$ & $\mathrm{H} 18 \mathrm{D}-\mathrm{C} 18 \mathrm{~A}-\mathrm{H} 18 \mathrm{~F}$ & 109.5 \\
\hline $\mathrm{O} 5-\mathrm{C} 13-\mathrm{C} 14$ & $111.8(5)$ & $\mathrm{H} 18 \mathrm{E}-\mathrm{C} 18 \mathrm{~A}-\mathrm{H} 18 \mathrm{~F}$ & 109.5 \\
\hline $\mathrm{O} 5-\mathrm{C} 13-\mathrm{C} 12$ & $109.5(5)$ & $\mathrm{C} 20 \mathrm{~A}-\mathrm{C} 19 \mathrm{~A}-\mathrm{C} 21 \mathrm{~A}$ & $111(3)$ \\
\hline $\mathrm{C} 14 \mathrm{~A}-\mathrm{C} 13-\mathrm{C} 12$ & $108.9(6)$ & $\mathrm{C} 20 \mathrm{~A}-\mathrm{C} 19 \mathrm{~A}-\mathrm{Si} 1 \mathrm{~A}$ & $110(3)$ \\
\hline $\mathrm{C} 14-\mathrm{C} 13-\mathrm{C} 12$ & $108.9(6)$ & $\mathrm{C} 21 \mathrm{~A}-\mathrm{C} 19 \mathrm{~A}-\mathrm{Si} 1 \mathrm{~A}$ & $114(3)$ \\
\hline $\mathrm{O} 5-\mathrm{C} 13-\mathrm{H} 13$ & 108.9 & $\mathrm{C} 20 \mathrm{~A}-\mathrm{C} 19 \mathrm{~A}-\mathrm{H} 19 \mathrm{~A}$ & 106.9 \\
\hline $\mathrm{C} 14-\mathrm{C} 13-\mathrm{H} 13$ & 108.9 & $\mathrm{C} 21 \mathrm{~A}-\mathrm{C} 19 \mathrm{~A}-\mathrm{H} 19 \mathrm{~A}$ & 106.9 \\
\hline $\mathrm{C} 12-\mathrm{C} 13-\mathrm{H} 13$ & 108.9 & Si1A-C19A-H19A & 106.9 \\
\hline $\mathrm{O} 5-\mathrm{C} 13-\mathrm{H} 13 \mathrm{~A}$ & 108.9 & $\mathrm{C} 19 \mathrm{~A}-\mathrm{C} 20 \mathrm{~A}-\mathrm{H} 20 \mathrm{D}$ & 109.5 \\
\hline $\mathrm{C} 14 \mathrm{~A}-\mathrm{C} 13-\mathrm{H} 13 \mathrm{~A}$ & 108.9 & $\mathrm{C} 19 \mathrm{~A}-\mathrm{C} 20 \mathrm{~A}-\mathrm{H} 20 \mathrm{E}$ & 109.5 \\
\hline $\mathrm{C} 12-\mathrm{C} 13-\mathrm{H} 13 \mathrm{~A}$ & 108.9 & $\mathrm{H} 20 \mathrm{D}-\mathrm{C} 20 \mathrm{~A}-\mathrm{H} 20 \mathrm{E}$ & 109.5 \\
\hline $\mathrm{C} 15-\mathrm{C} 14-\mathrm{C} 13$ & $173.3(17)$ & $\mathrm{C} 19 \mathrm{~A}-\mathrm{C} 20 \mathrm{~A}-\mathrm{H} 20 \mathrm{~F}$ & 109.5 \\
\hline $\mathrm{C} 14-\mathrm{C} 15-\mathrm{Si} 1$ & $168(3)$ & $\mathrm{H} 20 \mathrm{D}-\mathrm{C} 20 \mathrm{~A}-\mathrm{H} 20 \mathrm{~F}$ & 109.5 \\
\hline $\mathrm{C} 15-\mathrm{Si} 1-\mathrm{C} 16$ & $104.6(11)$ & $\mathrm{H} 20 \mathrm{E}-\mathrm{C} 20 \mathrm{~A}-\mathrm{H} 20 \mathrm{~F}$ & 109.5 \\
\hline $\mathrm{C} 15-\mathrm{Si} 1-\mathrm{C} 19$ & $108.3(14)$ & $\mathrm{C} 19 \mathrm{~A}-\mathrm{C} 21 \mathrm{~A}-\mathrm{H} 21 \mathrm{D}$ & 109.5 \\
\hline $\mathrm{C} 16-\mathrm{Si} 1-\mathrm{C} 19$ & $111.1(8)$ & $\mathrm{C} 19 \mathrm{~A}-\mathrm{C} 21 \mathrm{~A}-\mathrm{H} 21 \mathrm{E}$ & 109.5 \\
\hline $\mathrm{C} 15-\mathrm{Si} 1-\mathrm{C} 22$ & $103.5(9)$ & $\mathrm{H} 21 \mathrm{D}-\mathrm{C} 21 \mathrm{~A}-\mathrm{H} 21 \mathrm{E}$ & 109.5 \\
\hline $\mathrm{C} 16-\mathrm{Si} 1-\mathrm{C} 22$ & $111.5(7)$ & $\mathrm{C} 19 \mathrm{~A}-\mathrm{C} 21 \mathrm{~A}-\mathrm{H} 21 \mathrm{~F}$ & 109.5 \\
\hline $\mathrm{C} 19-\mathrm{Si} 1-\mathrm{C} 22$ & $116.8(9)$ & $\mathrm{H} 21 \mathrm{D}-\mathrm{C} 21 \mathrm{~A}-\mathrm{H} 21 \mathrm{~F}$ & 109.5 \\
\hline $\mathrm{C} 18-\mathrm{C} 16-\mathrm{C} 17$ & $111.7(13)$ & $\mathrm{H} 21 \mathrm{E}-\mathrm{C} 21 \mathrm{~A}-\mathrm{H} 21 \mathrm{~F}$ & 109.5 \\
\hline $\mathrm{C} 18-\mathrm{C} 16-\mathrm{Si} 1$ & $109.4(8)$ & $\mathrm{C} 24 \mathrm{~A}-\mathrm{C} 22 \mathrm{~A}-\mathrm{C} 23 \mathrm{~A}$ & $112(3)$ \\
\hline $\mathrm{C} 17-\mathrm{C} 16-\mathrm{Si} 1$ & $114.1(12)$ & $\mathrm{C} 24 \mathrm{~A}-\mathrm{C} 22 \mathrm{~A}-\mathrm{Si} 1 \mathrm{~A}$ & $114(3)$ \\
\hline $\mathrm{C} 18-\mathrm{C} 16-\mathrm{H} 16$ & 107.1 & $\mathrm{C} 23 \mathrm{~A}-\mathrm{C} 22 \mathrm{~A}-\mathrm{Si} 1 \mathrm{~A}$ & $104(2)$ \\
\hline $\mathrm{C} 17-\mathrm{C} 16-\mathrm{H} 16$ & 107.1 & $\mathrm{C} 24 \mathrm{~A}-\mathrm{C} 22 \mathrm{~A}-\mathrm{H} 22 \mathrm{~A}$ & 108.8 \\
\hline $\mathrm{Si} 1-\mathrm{C} 16-\mathrm{H} 16$ & 107.1 & $\mathrm{C} 23 \mathrm{~A}-\mathrm{C} 22 \mathrm{~A}-\mathrm{H} 22 \mathrm{~A}$ & 108.8 \\
\hline $\mathrm{C} 16-\mathrm{C} 17-\mathrm{H} 17 \mathrm{~A}$ & 109.5 & $\mathrm{Si} 1 \mathrm{~A}-\mathrm{C} 22 \mathrm{~A}-\mathrm{H} 22 \mathrm{~A}$ & 108.8 \\
\hline $\mathrm{C} 16-\mathrm{C} 17-\mathrm{H} 17 \mathrm{~B}$ & 109.5 & $\mathrm{C} 22 \mathrm{~A}-\mathrm{C} 23 \mathrm{~A}-\mathrm{H} 23 \mathrm{D}$ & 109.5 \\
\hline
\end{tabular}


Table S2 (Continued)

\begin{tabular}{|c|c|c|c|}
\hline $\mathrm{H} 17 \mathrm{~A}-\mathrm{C} 17-\mathrm{H} 17 \mathrm{~B}$ & 109.5 & $\mathrm{C} 22 \mathrm{~A}-\mathrm{C} 23 \mathrm{~A}-\mathrm{H} 23 \mathrm{E}$ & 109.5 \\
\hline $\mathrm{C} 16-\mathrm{C} 17-\mathrm{H} 17 \mathrm{C}$ & 109.5 & $\mathrm{H} 23 \mathrm{D}-\mathrm{C} 23 \mathrm{~A}-\mathrm{H} 23 \mathrm{E}$ & 109.5 \\
\hline $\mathrm{H} 17 \mathrm{~A}-\mathrm{C} 17-\mathrm{H} 17 \mathrm{C}$ & 109.5 & $\mathrm{C} 22 \mathrm{~A}-\mathrm{C} 23 \mathrm{~A}-\mathrm{H} 23 \mathrm{~F}$ & 109.5 \\
\hline $\mathrm{H} 17 \mathrm{~B}-\mathrm{C} 17-\mathrm{H} 17 \mathrm{C}$ & 109.5 & $\mathrm{H} 23 \mathrm{D}-\mathrm{C} 23 \mathrm{~A}-\mathrm{H} 23 \mathrm{~F}$ & 109.5 \\
\hline $\mathrm{C} 16-\mathrm{C} 18-\mathrm{H} 18 \mathrm{~A}$ & 109.5 & $\mathrm{H} 23 \mathrm{E}-\mathrm{C} 23 \mathrm{~A}-\mathrm{H} 23 \mathrm{~F}$ & 109.5 \\
\hline $\mathrm{C} 16-\mathrm{C} 18-\mathrm{H} 18 \mathrm{~B}$ & 109.5 & $\mathrm{C} 22 \mathrm{~A}-\mathrm{C} 24 \mathrm{~A}-\mathrm{H} 24 \mathrm{D}$ & 109.5 \\
\hline $\mathrm{H} 18 \mathrm{~A}-\mathrm{C} 18-\mathrm{H} 18 \mathrm{~B}$ & 109.5 & $\mathrm{C} 22 \mathrm{~A}-\mathrm{C} 24 \mathrm{~A}-\mathrm{H} 24 \mathrm{E}$ & 109.5 \\
\hline $\mathrm{C} 16-\mathrm{C} 18-\mathrm{H} 18 \mathrm{C}$ & 109.5 & $\mathrm{H} 24 \mathrm{D}-\mathrm{C} 24 \mathrm{~A}-\mathrm{H} 24 \mathrm{E}$ & 109.5 \\
\hline $\mathrm{H} 18 \mathrm{~A}-\mathrm{C} 18-\mathrm{H} 18 \mathrm{C}$ & 109.5 & $\mathrm{C} 22 \mathrm{~A}-\mathrm{C} 24 \mathrm{~A}-\mathrm{H} 24 \mathrm{~F}$ & 109.5 \\
\hline $\mathrm{H} 18 \mathrm{~B}-\mathrm{C} 18-\mathrm{H} 18 \mathrm{C}$ & 109.5 & $\mathrm{H} 24 \mathrm{D}-\mathrm{C} 24 \mathrm{~A}-\mathrm{H} 24 \mathrm{~F}$ & 109.5 \\
\hline $\mathrm{C} 20-\mathrm{C} 19-\mathrm{C} 21$ & 109.7 (19) & $\mathrm{H} 24 \mathrm{E}-\mathrm{C} 24 \mathrm{~A}-\mathrm{H} 24 \mathrm{~F}$ & 109.5 \\
\hline $\mathrm{C} 20-\mathrm{C} 19-\mathrm{Si} 1$ & $116.0(15)$ & $\mathrm{O} 3-\mathrm{N} 1-\mathrm{C} 10$ & $131.2(6)$ \\
\hline $\mathrm{C} 21-\mathrm{C} 19-\mathrm{Si} 1$ & $111.6(15)$ & $\mathrm{O} 3-\mathrm{N} 1-\mathrm{O} 2$ & $114.7(4)$ \\
\hline $\mathrm{C} 20-\mathrm{C} 19-\mathrm{H} 19$ & 106.3 & $\mathrm{C} 10-\mathrm{N} 1-\mathrm{O} 2$ & $114.1(5)$ \\
\hline $\mathrm{C} 21-\mathrm{C} 19-\mathrm{H} 19$ & 106.3 & $\mathrm{C} 8-\mathrm{O} 1-\mathrm{C} 7$ & $113.6(5)$ \\
\hline $\mathrm{Si} 1-\mathrm{C} 19-\mathrm{H} 19$ & 106.3 & $\mathrm{~N} 1-\mathrm{O} 2-\mathrm{C} 12$ & $107.2(4)$ \\
\hline $\mathrm{C} 19-\mathrm{C} 20-\mathrm{H} 20 \mathrm{~A}$ & 109.5 & $\mathrm{C} 11-\mathrm{O} 4-\mathrm{H} 4 \mathrm{~A}$ & 109.5 \\
\hline $\mathrm{C} 19-\mathrm{C} 20-\mathrm{H} 20 \mathrm{~B}$ & 109.5 & $\mathrm{C} 13-\mathrm{O} 5-\mathrm{H} 5 \mathrm{~A}$ & 109.5 \\
\hline $\mathrm{H} 20 \mathrm{~A}-\mathrm{C} 20-\mathrm{H} 20 \mathrm{~B}$ & 109.5 & & \\
\hline $\mathrm{C} 6-\mathrm{C} 1-\mathrm{C} 2-\mathrm{C} 3$ & $-0.4(13)$ & $\mathrm{C} 15-\mathrm{Si} 1-\mathrm{C} 16-\mathrm{C} 18$ & $64.9(15)$ \\
\hline $\mathrm{C} 1-\mathrm{C} 2-\mathrm{C} 3-\mathrm{C} 4$ & $0.8(13)$ & $\mathrm{C} 19-\mathrm{Si} 1-\mathrm{C} 16-\mathrm{C} 18$ & $-178.5(10)$ \\
\hline $\mathrm{C} 2-\mathrm{C} 3-\mathrm{C} 4-\mathrm{C} 5$ & $-0.5(14)$ & $\mathrm{C} 22-\mathrm{Si} 1-\mathrm{C} 16-\mathrm{C} 18$ & $-46.4(12)$ \\
\hline $\mathrm{C} 3-\mathrm{C} 4-\mathrm{C} 5-\mathrm{C} 6$ & $0.0(13)$ & $\mathrm{C} 15-\mathrm{Si} 1-\mathrm{C} 16-\mathrm{C} 17$ & $-61.1(16)$ \\
\hline $\mathrm{C} 2-\mathrm{C} 1-\mathrm{C} 6-\mathrm{C} 5$ & $-0.1(12)$ & $\mathrm{C} 19-\mathrm{Si} 1-\mathrm{C} 16-\mathrm{C} 17$ & $55.5(14)$ \\
\hline $\mathrm{C} 2-\mathrm{C} 1-\mathrm{C} 6-\mathrm{C} 7$ & $179.2(8)$ & $\mathrm{C} 22-\mathrm{Si} 1-\mathrm{C} 16-\mathrm{C} 17$ & $-172.4(12)$ \\
\hline $\mathrm{C} 4-\mathrm{C} 5-\mathrm{C} 6-\mathrm{C} 1$ & $0.3(12)$ & $\mathrm{C} 15-\mathrm{Si} 1-\mathrm{C} 19-\mathrm{C} 20$ & $37(2)$ \\
\hline $\mathrm{C} 4-\mathrm{C} 5-\mathrm{C} 6-\mathrm{C} 7$ & $-179.0(8)$ & $\mathrm{C} 16-\mathrm{Si} 1-\mathrm{C} 19-\mathrm{C} 20$ & $-77.8(18)$ \\
\hline $\mathrm{C} 1-\mathrm{C} 6-\mathrm{C} 7-\mathrm{O} 1$ & $-12.5(9)$ & $\mathrm{C} 22-\mathrm{Si} 1-\mathrm{C} 19-\mathrm{C} 20$ & $152.8(17)$ \\
\hline $\mathrm{C} 5-\mathrm{C} 6-\mathrm{C} 7-\mathrm{O} 1$ & $166.8(7)$ & $\mathrm{C} 15-\mathrm{Si} 1-\mathrm{C} 19-\mathrm{C} 21$ & $163.2(17)$ \\
\hline $\mathrm{O} 1-\mathrm{C} 8-\mathrm{C} 10-\mathrm{N} 1$ & $-114.6(6)$ & $\mathrm{C} 16-\mathrm{Si} 1-\mathrm{C} 19-\mathrm{C} 21$ & $48.9(19)$ \\
\hline $\mathrm{C} 9-\mathrm{C} 8-\mathrm{C} 10-\mathrm{N} 1$ & $125.6(7)$ & $\mathrm{C} 22-\mathrm{Si} 1-\mathrm{C} 19-\mathrm{C} 21$ & $-80.5(18)$ \\
\hline $\mathrm{O} 1-\mathrm{C} 8-\mathrm{C} 10-\mathrm{C} 11$ & $63.3(9)$ & $\mathrm{O} 5-\mathrm{C} 13-\mathrm{C} 14 \mathrm{~A}-\mathrm{C} 15 \mathrm{~A}$ & $79(28)$ \\
\hline $\mathrm{C} 9-\mathrm{C} 8-\mathrm{C} 10-\mathrm{C} 11$ & $-56.4(9)$ & $\mathrm{C} 12-\mathrm{C} 13-\mathrm{C} 14 \mathrm{~A}-\mathrm{C} 15 \mathrm{~A}$ & $-42(28)$ \\
\hline $\mathrm{N} 1-\mathrm{C} 10-\mathrm{C} 11-\mathrm{O} 4$ & $-117.9(6)$ & $\mathrm{C} 15 \mathrm{~A}-\mathrm{Si} 1 \mathrm{~A}-\mathrm{C} 16 \mathrm{~A}-\mathrm{C} 18 \mathrm{~A}$ & $39(4)$ \\
\hline
\end{tabular}


Table S2 (Continued)

\begin{tabular}{|l|l|l|l|}
\hline $\mathrm{C} 8-\mathrm{C} 10-\mathrm{C} 11-\mathrm{O} 4$ & $64.0(8)$ & $\mathrm{C} 22 \mathrm{~A}-\mathrm{Si1A}-\mathrm{C} 16 \mathrm{~A}-\mathrm{C} 18 \mathrm{~A}$ & $-95(3)$ \\
\hline $\mathrm{N} 1-\mathrm{C} 10-\mathrm{C} 11-\mathrm{C} 12$ & $4.9(7)$ & $\mathrm{C} 19 \mathrm{~A}-\mathrm{S} 11 \mathrm{~A}-\mathrm{C} 16 \mathrm{~A}-\mathrm{C} 18 \mathrm{~A}$ & $157(2)$ \\
\hline $\mathrm{C} 8-\mathrm{C} 10-\mathrm{C} 11-\mathrm{C} 12$ & $-173.2(6)$ & $\mathrm{C} 15 \mathrm{~A}-\mathrm{S} 11 \mathrm{~A}-\mathrm{C} 16 \mathrm{~A}-\mathrm{C} 17 \mathrm{~A}$ & $163(4)$ \\
\hline $\mathrm{O} 4-\mathrm{C} 11-\mathrm{C} 12-\mathrm{O} 2$ & $116.0(5)$ & $\mathrm{C} 22 \mathrm{~A}-\mathrm{S} 11-\mathrm{C} 16 \mathrm{~A}-\mathrm{C} 17 \mathrm{~A}$ & $29(3)$ \\
\hline $\mathrm{C} 10-\mathrm{C} 11-\mathrm{C} 12-\mathrm{O} 2$ & $-7.1(6)$ & $\mathrm{C} 19 \mathrm{~A}-\mathrm{Si1}-\mathrm{C} 16 \mathrm{~A}-\mathrm{C} 17 \mathrm{~A}$ & $-79(2)$ \\
\hline $\mathrm{O} 4-\mathrm{C} 11-\mathrm{C} 12-\mathrm{C} 13$ & $-124.6(6)$ & $\mathrm{C} 8-\mathrm{C} 10-\mathrm{N} 1-\mathrm{O} 3$ & $-0.7(11)$ \\
\hline $\mathrm{C} 10-\mathrm{C} 11-\mathrm{C} 12-\mathrm{C} 13$ & $112.3(6)$ & $\mathrm{C} 11-\mathrm{C} 10-\mathrm{N} 1-\mathrm{O} 3$ & $-179.0(6)$ \\
\hline $\mathrm{O} 2-\mathrm{C} 12-\mathrm{C} 13-\mathrm{O} 5$ & $67.1(6)$ & $\mathrm{C} 8-\mathrm{C} 10-\mathrm{N} 1-\mathrm{O} 2$ & $177.5(5)$ \\
\hline $\mathrm{C} 11-\mathrm{C} 12-\mathrm{C} 13-\mathrm{O} 5$ & $-50.6(7)$ & $\mathrm{C} 11-\mathrm{C} 10-\mathrm{N} 1-\mathrm{O} 2$ & $-0.9(7)$ \\
\hline $\mathrm{O} 2-\mathrm{C} 12-\mathrm{C} 13-\mathrm{C} 14 \mathrm{~A}$ & $-170.4(5)$ & $\mathrm{C} 10-\mathrm{C} 8-\mathrm{O} 1-\mathrm{C} 7$ & $65.1(7)$ \\
\hline $\mathrm{C} 11-\mathrm{C} 12-\mathrm{C} 13-\mathrm{C} 14 \mathrm{~A}$ & $71.9(7)$ & $\mathrm{C} 9-\mathrm{C} 8-\mathrm{O} 1-\mathrm{C} 7$ & $-171.1(6)$ \\
\hline $\mathrm{O} 2-\mathrm{C} 12-\mathrm{C} 13-\mathrm{C} 14$ & $-170.4(5)$ & $\mathrm{C} 6-\mathrm{C} 7-\mathrm{O} 1-\mathrm{C} 8$ & $172.2(5)$ \\
\hline $\mathrm{C} 11-\mathrm{C} 12-\mathrm{C} 13-\mathrm{C} 14$ & $71.9(7)$ & $\mathrm{O} 3-\mathrm{N} 1-\mathrm{O} 2-\mathrm{C} 12$ & $174.4(5)$ \\
\hline $\mathrm{C} 14-\mathrm{C} 15-\mathrm{Si} 1-\mathrm{C} 16$ & $-15(11)$ & $\mathrm{C} 10-\mathrm{N} 1-\mathrm{O} 2-\mathrm{C} 12$ & $-4.0(7)$ \\
\hline $\mathrm{C} 14-\mathrm{C} 15-\mathrm{S} 11-\mathrm{C} 19$ & $-134(11)$ & $\mathrm{C} 13-\mathrm{C} 12-\mathrm{O} 2-\mathrm{N} 1$ & $-116.4(5)$ \\
\hline $\mathrm{C} 14-\mathrm{C} 15-\mathrm{Si1}-\mathrm{C} 22$ & $102(10)$ & $\mathrm{C} 11-\mathrm{C} 12-\mathrm{O} 2-\mathrm{N} 1$ & $6.8(6)$ \\
\hline
\end{tabular}

Table S3. Hydrogen-bond parameters

\begin{tabular}{|l|l|l|l|l|}
\hline$D-\mathrm{H} \cdots A$ & $D-\mathrm{H}(\AA)$ & $\mathrm{H} \cdots A(\AA)$ & $D \cdots A(\AA)$ & $D-\mathrm{H} \cdots A\left({ }^{\circ}\right)$ \\
\hline $\mathrm{O} 4-\mathrm{H} 4 \mathrm{~A} \cdots \mathrm{O} 3^{\mathrm{i}}$ & 0.84 & 2.43 & $2.727(6)$ & 101.5 \\
\hline O5-H5A $\cdots \mathrm{O} 2$ & 0.84 & 2.46 & $2.871(6)$ & 111.1 \\
\hline
\end{tabular}

Symmetry code(s): (i) $-x+1, y-1 / 2,-z+1$. 


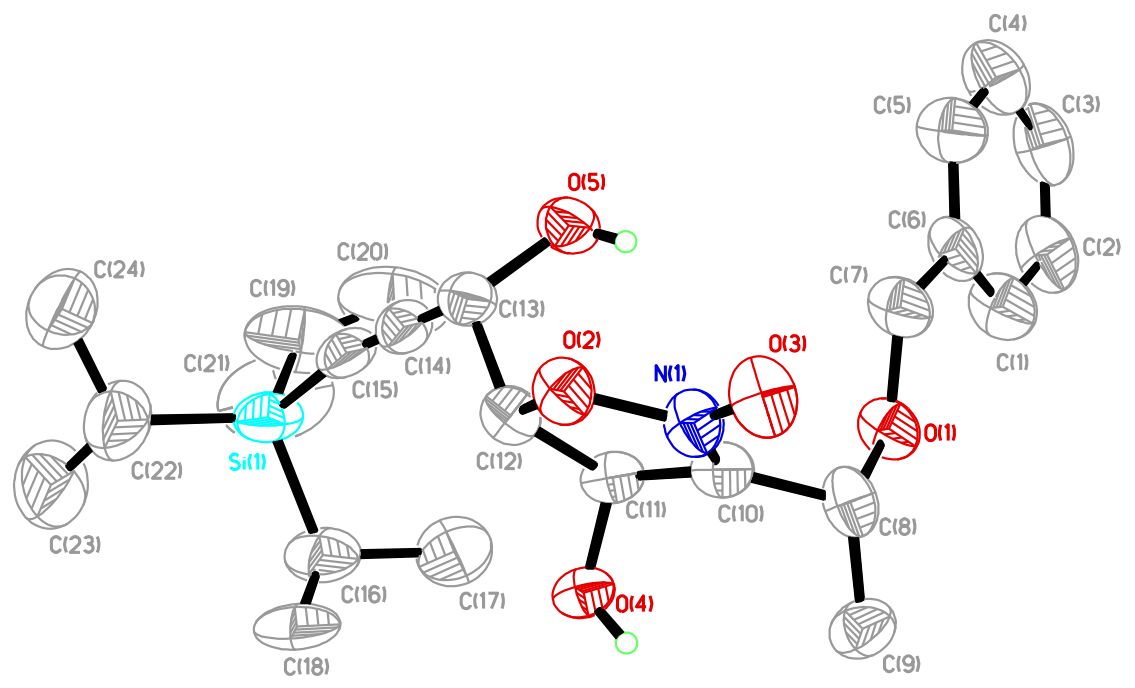

Figure S1. Perspective views showing 50\% probability displacement

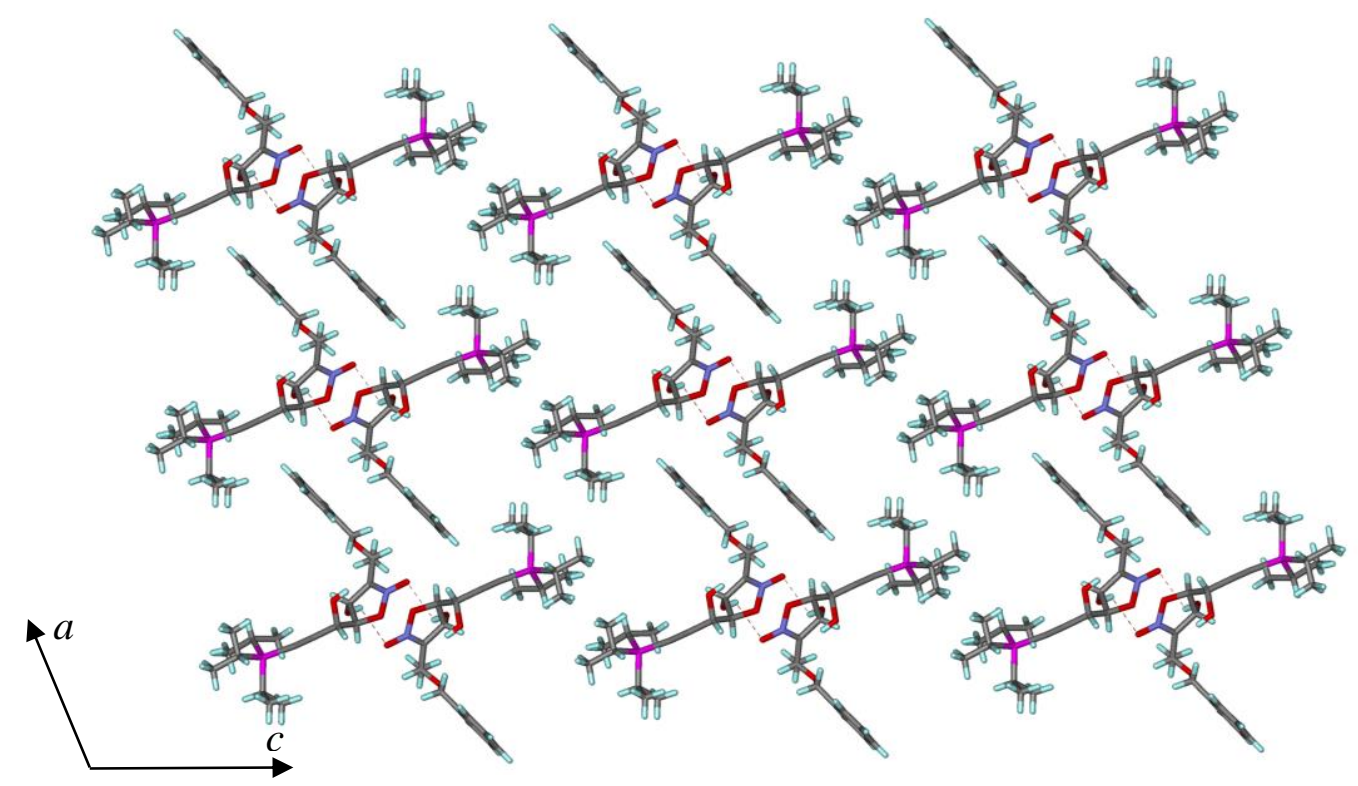

Figure S2. Three-dimensional supramolecular architecture viewed along the $b$-axis direction. 


\section{Crystallographic Data for Compound 22b}

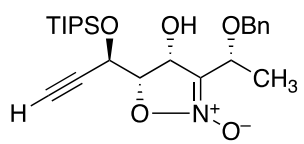

22b

Table S4. Experimental details

\begin{tabular}{|c|c|}
\hline \multicolumn{2}{|l|}{ CCDC Deposition Number 2072280} \\
\hline Chemical formula & $\mathrm{C}_{24} \mathrm{H}_{37} \mathrm{NO}_{5} \mathrm{Si}$ \\
\hline$M_{\mathrm{r}}$ & 447.63 \\
\hline Crystal system, space group & Monoclinic, $P 2_{1}$ \\
\hline Temperature $(\mathrm{K})$ & 100 \\
\hline$a, b, c(\AA)$ & $10.4700(7), 6.9042(4), 17.1454(10)$ \\
\hline$\beta\left(\left(^{\circ}\right)\right.$ & $92.914(5)$ \\
\hline$V\left(\AA^{3}\right)$ & $1237.79(13)$ \\
\hline$Z$ & 2 \\
\hline Radiation type & $\mathrm{Cu} K \alpha$ \\
\hline$\mu\left(\mathrm{mm}^{-1}\right)$ & 1.11 \\
\hline Crystal size (mm) & $0.16 \times 0.08 \times 0.01$ \\
\hline \multicolumn{2}{|l|}{ Data collection } \\
\hline Diffractometer & Bruker D8 goniometer with CCD area detector diffractometer \\
\hline Absorption correction & $\begin{array}{l}\text { Multi-scan } \\
S A D A B S\end{array}$ \\
\hline$T_{\min }, T_{\max }$ & $0.688,0.864$ \\
\hline $\begin{array}{l}\text { No. of measured, independent and } \\
\text { observed }[I>2 \sigma(I)] \text { reflections }\end{array}$ & $16287,3956,3393$ \\
\hline$R_{\text {int }}$ & 0.081 \\
\hline$(\sin \theta / \lambda)_{\max }\left(\AA^{-1}\right)$ & 0.596 \\
\hline \multicolumn{2}{|l|}{ Refinement } \\
\hline$R\left[F^{2}>2 \sigma\left(F^{2}\right)\right], w R\left(F^{2}\right), S$ & $0.055,0.143,1.10$ \\
\hline No. of reflections & 3956 \\
\hline No. of parameters & 291 \\
\hline No. of restraints & 1 \\
\hline
\end{tabular}


Table S4 (Continued)

\begin{tabular}{|l|l|}
\hline H-atom treatment & H atoms treated by a mixture of independent and constrained refinement \\
\hline$\Delta \rho_{\max }, \Delta \rho_{\min }\left(\mathrm{e} \AA^{-3}\right)$ & $0.32,-0.41$ \\
\hline Absolute structure & $\begin{array}{l}\text { Flack x determined using 1252 quotients [(I+)-(I-)]/[(I+)+(I-)] (Parsons, } \\
\text { Flack and Wagner, Acta Cryst. B69 (2013) 249-259). }\end{array}$ \\
\hline Absolute structure parameter & $0.01(5)$ \\
\hline
\end{tabular}

Computer programs: APEX3 v2015.5.2 (Bruker-AXS, 2015), SAINT 8.34C (Bruker-AXS, 2014), SHELXT2014 (Sheldrick, 2015), SHELXL2014 (Sheldrick, 2015), Bruker SHELXTL (Sheldrick, 2015).

Table S5. Geometric parameters $\left(\stackrel{\AA}{{ }^{\circ}}{ }^{\circ}\right)$

\begin{tabular}{|l|l|l|l|}
\hline $\mathrm{C} 1-\mathrm{C} 2$ & $1.184(7)$ & $\mathrm{C} 16-\mathrm{C} 17$ & $1.534(8)$ \\
\hline $\mathrm{C} 1-\mathrm{H} 1$ & 0.9500 & $\mathrm{C} 16-\mathrm{C} 18$ & $1.535(7)$ \\
\hline $\mathrm{C} 2-\mathrm{C} 3$ & $1.480(7)$ & $\mathrm{C} 16-\mathrm{S} 11$ & $1.885(5)$ \\
\hline $\mathrm{C} 3-\mathrm{O} 1$ & $1.419(5)$ & $\mathrm{C} 16-\mathrm{H} 16$ & 1.0000 \\
\hline $\mathrm{C} 3-\mathrm{C} 4$ & $1.529(6)$ & $\mathrm{C} 17-\mathrm{H} 17 \mathrm{~A}$ & 0.9800 \\
\hline $\mathrm{C} 3-\mathrm{H} 3$ & 1.0000 & $\mathrm{C} 17-\mathrm{H} 17 \mathrm{~B}$ & 0.9800 \\
\hline $\mathrm{C} 4-\mathrm{O} 4$ & $1.454(5)$ & $\mathrm{C} 17-\mathrm{H} 17 \mathrm{C}$ & 0.9800 \\
\hline $\mathrm{C} 4-\mathrm{C} 5$ & $1.537(6)$ & $\mathrm{C} 18-\mathrm{H} 18 \mathrm{~A}$ & 0.9800 \\
\hline $\mathrm{C} 4-\mathrm{H} 4$ & 1.0000 & $\mathrm{C} 18-\mathrm{H} 18 \mathrm{~B}$ & 0.9800 \\
\hline $\mathrm{C} 5-\mathrm{O} 2$ & $1.410(6)$ & $\mathrm{C} 18-\mathrm{H} 18 \mathrm{C}$ & 0.9800 \\
\hline $\mathrm{C} 5-\mathrm{C} 6$ & $1.495(6)$ & $\mathrm{C} 19-\mathrm{C} 21$ & $1.538(7)$ \\
\hline $\mathrm{C} 5-\mathrm{H} 5$ & 1.0000 & $\mathrm{C} 19-\mathrm{C} 20$ & $1.542(7)$ \\
\hline $\mathrm{C} 6-\mathrm{N} 1$ & $1.300(6)$ & $\mathrm{C} 19-\mathrm{Si} 1$ & $1.882(6)$ \\
\hline $\mathrm{C} 6-\mathrm{C} 7$ & $1.505(6)$ & $\mathrm{C} 19-\mathrm{H} 19$ & 1.0000 \\
\hline $\mathrm{C} 7-\mathrm{O} 3$ & $1.426(6)$ & $\mathrm{C} 20-\mathrm{H} 20 \mathrm{~A}$ & 0.9800 \\
\hline $\mathrm{C} 7-\mathrm{C} 15$ & $1.516(7)$ & $\mathrm{C} 20-\mathrm{H} 20 \mathrm{~B}$ & 0.9800 \\
\hline $\mathrm{C} 7-\mathrm{H} 7$ & 1.0000 & $\mathrm{C} 20-\mathrm{H} 20 \mathrm{C}$ & 0.9800 \\
\hline $\mathrm{C} 8-\mathrm{O} 3$ & $1.435(6)$ & $\mathrm{C} 21-\mathrm{H} 21 \mathrm{~A}$ & 0.9800 \\
\hline $\mathrm{C} 8-\mathrm{C} 9$ & $1.508(7)$ & $\mathrm{C} 21-\mathrm{H} 21 \mathrm{~B}$ & 0.9800 \\
\hline $\mathrm{C} 8-\mathrm{H} 8 \mathrm{~A}$ & 0.9900 & $\mathrm{C} 22-\mathrm{C} 23$ & 0.9800 \\
\hline $\mathrm{C} 8-\mathrm{H} 8 \mathrm{~B}$ & 0.9900 & $1.525(7)$ \\
\hline $\mathrm{C} 9-\mathrm{C} 10$ & $1.379(8)$ & $1.532(7)$ \\
\hline
\end{tabular}


Table S5 (Continued)

\begin{tabular}{|c|c|c|c|}
\hline $\mathrm{C} 9-\mathrm{C} 14$ & $1.392(8)$ & $\mathrm{C} 22-\mathrm{Si} 1$ & $1.880(5)$ \\
\hline $\mathrm{C} 10-\mathrm{C} 11$ & $1.396(7)$ & $\mathrm{C} 22-\mathrm{H} 22$ & 1.0000 \\
\hline $\mathrm{C} 10-\mathrm{H} 10$ & 0.9500 & $\mathrm{C} 23-\mathrm{H} 23 \mathrm{~A}$ & 0.9800 \\
\hline $\mathrm{C} 11-\mathrm{C} 12$ & $1.371(9)$ & $\mathrm{C} 23-\mathrm{H} 23 \mathrm{~B}$ & 0.9800 \\
\hline $\mathrm{C} 11-\mathrm{H} 11$ & 0.9500 & $\mathrm{C} 23-\mathrm{H} 23 \mathrm{C}$ & 0.9800 \\
\hline $\mathrm{C} 12-\mathrm{C} 13$ & $1.385(9)$ & $\mathrm{C} 24-\mathrm{H} 24 \mathrm{~A}$ & 0.9800 \\
\hline $\mathrm{C} 12-\mathrm{H} 12$ & 0.9500 & $\mathrm{C} 24-\mathrm{H} 24 \mathrm{~B}$ & 0.9800 \\
\hline $\mathrm{C} 13-\mathrm{C} 14$ & $1.403(8)$ & $\mathrm{C} 24-\mathrm{H} 24 \mathrm{C}$ & 0.9800 \\
\hline C13-H13 & 0.9500 & $\mathrm{~N} 1-\mathrm{O} 5$ & $1.259(5)$ \\
\hline C14-H14 & 0.9500 & $\mathrm{~N} 1-\mathrm{O} 4$ & $1.435(4)$ \\
\hline C15-H15A & 0.9800 & $\mathrm{O} 1-\mathrm{Si} 1$ & $1.672(3)$ \\
\hline C15-H15B & 0.9800 & $\mathrm{O} 2-\mathrm{H} 2$ & $0.84(8)$ \\
\hline $\mathrm{C} 15-\mathrm{H} 15 \mathrm{C}$ & 0.9800 & & \\
\hline $\mathrm{C} 2-\mathrm{C} 1-\mathrm{H} 1$ & 180.0 & $\mathrm{C} 18-\mathrm{C} 16-\mathrm{H} 16$ & 106.3 \\
\hline $\mathrm{C} 1-\mathrm{C} 2-\mathrm{C} 3$ & $176.0(5)$ & $\mathrm{Si} 1-\mathrm{C} 16-\mathrm{H} 16$ & 106.3 \\
\hline $\mathrm{O} 1-\mathrm{C} 3-\mathrm{C} 2$ & $112.5(3)$ & $\mathrm{C} 16-\mathrm{C} 17-\mathrm{H} 17 \mathrm{~A}$ & 109.5 \\
\hline $\mathrm{O} 1-\mathrm{C} 3-\mathrm{C} 4$ & $105.6(4)$ & $\mathrm{C} 16-\mathrm{C} 17-\mathrm{H} 17 \mathrm{~B}$ & 109.5 \\
\hline $\mathrm{C} 2-\mathrm{C} 3-\mathrm{C} 4$ & $109.9(4)$ & $\mathrm{H} 17 \mathrm{~A}-\mathrm{C} 17-\mathrm{H} 17 \mathrm{~B}$ & 109.5 \\
\hline $\mathrm{O} 1-\mathrm{C} 3-\mathrm{H} 3$ & 109.6 & $\mathrm{C} 16-\mathrm{C} 17-\mathrm{H} 17 \mathrm{C}$ & 109.5 \\
\hline $\mathrm{C} 2-\mathrm{C} 3-\mathrm{H} 3$ & 109.6 & $\mathrm{H} 17 \mathrm{~A}-\mathrm{C} 17-\mathrm{H} 17 \mathrm{C}$ & 109.5 \\
\hline $\mathrm{C} 4-\mathrm{C} 3-\mathrm{H} 3$ & 109.6 & $\mathrm{H} 17 \mathrm{~B}-\mathrm{C} 17-\mathrm{H} 17 \mathrm{C}$ & 109.5 \\
\hline $\mathrm{O} 4-\mathrm{C} 4-\mathrm{C} 3$ & $107.5(4)$ & $\mathrm{C} 16-\mathrm{C} 18-\mathrm{H} 18 \mathrm{~A}$ & 109.5 \\
\hline $\mathrm{O} 4-\mathrm{C} 4-\mathrm{C} 5$ & $105.5(3)$ & $\mathrm{C} 16-\mathrm{C} 18-\mathrm{H} 18 \mathrm{~B}$ & 109.5 \\
\hline $\mathrm{C} 3-\mathrm{C} 4-\mathrm{C} 5$ & $115.0(4)$ & $\mathrm{H} 18 \mathrm{~A}-\mathrm{C} 18-\mathrm{H} 18 \mathrm{~B}$ & 109.5 \\
\hline $\mathrm{O} 4-\mathrm{C} 4-\mathrm{H} 4$ & 109.6 & $\mathrm{C} 16-\mathrm{C} 18-\mathrm{H} 18 \mathrm{C}$ & 109.5 \\
\hline $\mathrm{C} 3-\mathrm{C} 4-\mathrm{H} 4$ & 109.6 & $\mathrm{H} 18 \mathrm{~A}-\mathrm{C} 18-\mathrm{H} 18 \mathrm{C}$ & 109.5 \\
\hline $\mathrm{C} 5-\mathrm{C} 4-\mathrm{H} 4$ & 109.6 & $\mathrm{H} 18 \mathrm{~B}-\mathrm{C} 18-\mathrm{H} 18 \mathrm{C}$ & 109.5 \\
\hline $\mathrm{O} 2-\mathrm{C} 5-\mathrm{C} 6$ & $110.1(4)$ & $\mathrm{C} 21-\mathrm{C} 19-\mathrm{C} 20$ & $110.6(4)$ \\
\hline $\mathrm{O} 2-\mathrm{C} 5-\mathrm{C} 4$ & $117.0(4)$ & $\mathrm{C} 21-\mathrm{C} 19-\mathrm{Si} 1$ & $116.6(4)$ \\
\hline $\mathrm{C} 6-\mathrm{C} 5-\mathrm{C} 4$ & $99.9(4)$ & $\mathrm{C} 20-\mathrm{C} 19-\mathrm{Si} 1$ & $113.9(4)$ \\
\hline $\mathrm{O} 2-\mathrm{C} 5-\mathrm{H} 5$ & 109.8 & $\mathrm{C} 21-\mathrm{C} 19-\mathrm{H} 19$ & 104.8 \\
\hline $\mathrm{C} 6-\mathrm{C} 5-\mathrm{H} 5$ & 109.8 & $\mathrm{C} 20-\mathrm{C} 19-\mathrm{H} 19$ & 104.8 \\
\hline $\mathrm{C} 4-\mathrm{C} 5-\mathrm{H} 5$ & 109.8 & Si1-C19-H19 & 104.8 \\
\hline $\mathrm{N} 1-\mathrm{C} 6-\mathrm{C} 5$ & $110.2(4)$ & $\mathrm{C} 19-\mathrm{C} 20-\mathrm{H} 20 \mathrm{~A}$ & 109.5 \\
\hline
\end{tabular}


Table S5 (Continued)

\begin{tabular}{|c|c|c|c|}
\hline $\mathrm{N} 1-\mathrm{C} 6-\mathrm{C} 7$ & $121.0(4)$ & $\mathrm{C} 19-\mathrm{C} 20-\mathrm{H} 20 \mathrm{~B}$ & 109.5 \\
\hline $\mathrm{C} 5-\mathrm{C} 6-\mathrm{C} 7$ & $128.5(4)$ & $\mathrm{H} 20 \mathrm{~A}-\mathrm{C} 20-\mathrm{H} 20 \mathrm{~B}$ & 109.5 \\
\hline $\mathrm{O} 3-\mathrm{C} 7-\mathrm{C} 6$ & $108.6(4)$ & $\mathrm{C} 19-\mathrm{C} 20-\mathrm{H} 20 \mathrm{C}$ & 109.5 \\
\hline $\mathrm{O} 3-\mathrm{C} 7-\mathrm{C} 15$ & $107.1(4)$ & $\mathrm{H} 20 \mathrm{~A}-\mathrm{C} 20-\mathrm{H} 20 \mathrm{C}$ & 109.5 \\
\hline $\mathrm{C} 6-\mathrm{C} 7-\mathrm{C} 15$ & $112.0(4)$ & $\mathrm{H} 20 \mathrm{~B}-\mathrm{C} 20-\mathrm{H} 20 \mathrm{C}$ & 109.5 \\
\hline $\mathrm{O} 3-\mathrm{C} 7-\mathrm{H} 7$ & 109.7 & $\mathrm{C} 19-\mathrm{C} 21-\mathrm{H} 21 \mathrm{~A}$ & 109.5 \\
\hline $\mathrm{C} 6-\mathrm{C} 7-\mathrm{H} 7$ & 109.7 & $\mathrm{C} 19-\mathrm{C} 21-\mathrm{H} 21 \mathrm{~B}$ & 109.5 \\
\hline $\mathrm{C} 15-\mathrm{C} 7-\mathrm{H} 7$ & 109.7 & $\mathrm{H} 21 \mathrm{~A}-\mathrm{C} 21-\mathrm{H} 21 \mathrm{~B}$ & 109.5 \\
\hline $\mathrm{O} 3-\mathrm{C} 8-\mathrm{C} 9$ & $109.9(4)$ & $\mathrm{C} 19-\mathrm{C} 21-\mathrm{H} 21 \mathrm{C}$ & 109.5 \\
\hline $\mathrm{O} 3-\mathrm{C} 8-\mathrm{H} 8 \mathrm{~A}$ & 109.7 & $\mathrm{H} 21 \mathrm{~A}-\mathrm{C} 21-\mathrm{H} 21 \mathrm{C}$ & 109.5 \\
\hline $\mathrm{C} 9-\mathrm{C} 8-\mathrm{H} 8 \mathrm{~A}$ & 109.7 & $\mathrm{H} 21 \mathrm{~B}-\mathrm{C} 21-\mathrm{H} 21 \mathrm{C}$ & 109.5 \\
\hline $\mathrm{O} 3-\mathrm{C} 8-\mathrm{H} 8 \mathrm{~B}$ & 109.7 & $\mathrm{C} 23-\mathrm{C} 22-\mathrm{C} 24$ & $109.9(4)$ \\
\hline $\mathrm{C} 9-\mathrm{C} 8-\mathrm{H} 8 \mathrm{~B}$ & 109.7 & C23-C22-Si1 & $113.2(4)$ \\
\hline $\mathrm{H} 8 \mathrm{~A}-\mathrm{C} 8-\mathrm{H} 8 \mathrm{~B}$ & 108.2 & $\mathrm{C} 24-\mathrm{C} 22-\mathrm{Si} 1$ & $113.9(3)$ \\
\hline $\mathrm{C} 10-\mathrm{C} 9-\mathrm{C} 14$ & $119.5(5)$ & $\mathrm{C} 23-\mathrm{C} 22-\mathrm{H} 22$ & 106.4 \\
\hline $\mathrm{C} 10-\mathrm{C} 9-\mathrm{C} 8$ & $122.0(5)$ & $\mathrm{C} 24-\mathrm{C} 22-\mathrm{H} 22$ & 106.4 \\
\hline $\mathrm{C} 14-\mathrm{C} 9-\mathrm{C} 8$ & $118.3(5)$ & $\mathrm{Si} 1-\mathrm{C} 22-\mathrm{H} 22$ & 106.4 \\
\hline $\mathrm{C} 9-\mathrm{C} 10-\mathrm{C} 11$ & $120.4(6)$ & $\mathrm{C} 22-\mathrm{C} 23-\mathrm{H} 23 \mathrm{~A}$ & 109.5 \\
\hline $\mathrm{C} 9-\mathrm{C} 10-\mathrm{H} 10$ & 119.8 & $\mathrm{C} 22-\mathrm{C} 23-\mathrm{H} 23 \mathrm{~B}$ & 109.5 \\
\hline $\mathrm{C} 11-\mathrm{C} 10-\mathrm{H} 10$ & 119.8 & $\mathrm{H} 23 \mathrm{~A}-\mathrm{C} 23-\mathrm{H} 23 \mathrm{~B}$ & 109.5 \\
\hline $\mathrm{C} 12-\mathrm{C} 11-\mathrm{C} 10$ & $120.3(6)$ & $\mathrm{C} 22-\mathrm{C} 23-\mathrm{H} 23 \mathrm{C}$ & 109.5 \\
\hline $\mathrm{C} 12-\mathrm{C} 11-\mathrm{H} 11$ & 119.9 & $\mathrm{H} 23 \mathrm{~A}-\mathrm{C} 23-\mathrm{H} 23 \mathrm{C}$ & 109.5 \\
\hline $\mathrm{C} 10-\mathrm{C} 11-\mathrm{H} 11$ & 119.9 & $\mathrm{H} 23 \mathrm{~B}-\mathrm{C} 23-\mathrm{H} 23 \mathrm{C}$ & 109.5 \\
\hline $\mathrm{C} 11-\mathrm{C} 12-\mathrm{C} 13$ & $120.1(5)$ & $\mathrm{C} 22-\mathrm{C} 24-\mathrm{H} 24 \mathrm{~A}$ & 109.5 \\
\hline $\mathrm{C} 11-\mathrm{C} 12-\mathrm{H} 12$ & 119.9 & $\mathrm{C} 22-\mathrm{C} 24-\mathrm{H} 24 \mathrm{~B}$ & 109.5 \\
\hline $\mathrm{C} 13-\mathrm{C} 12-\mathrm{H} 12$ & 119.9 & $\mathrm{H} 24 \mathrm{~A}-\mathrm{C} 24-\mathrm{H} 24 \mathrm{~B}$ & 109.5 \\
\hline $\mathrm{C} 12-\mathrm{C} 13-\mathrm{C} 14$ & $119.8(6)$ & $\mathrm{C} 22-\mathrm{C} 24-\mathrm{H} 24 \mathrm{C}$ & 109.5 \\
\hline $\mathrm{C} 12-\mathrm{C} 13-\mathrm{H} 13$ & 120.1 & $\mathrm{H} 24 \mathrm{~A}-\mathrm{C} 24-\mathrm{H} 24 \mathrm{C}$ & 109.5 \\
\hline $\mathrm{C} 14-\mathrm{C} 13-\mathrm{H} 13$ & 120.1 & $\mathrm{H} 24 \mathrm{~B}-\mathrm{C} 24-\mathrm{H} 24 \mathrm{C}$ & 109.5 \\
\hline $\mathrm{C} 9-\mathrm{C} 14-\mathrm{C} 13$ & $119.9(6)$ & $\mathrm{O} 5-\mathrm{N} 1-\mathrm{C} 6$ & $132.6(4)$ \\
\hline $\mathrm{C} 9-\mathrm{C} 14-\mathrm{H} 14$ & 120.1 & $\mathrm{O} 5-\mathrm{N} 1-\mathrm{O} 4$ & $114.4(3)$ \\
\hline $\mathrm{C} 13-\mathrm{C} 14-\mathrm{H} 14$ & 120.1 & $\mathrm{C} 6-\mathrm{N} 1-\mathrm{O} 4$ & $112.9(4)$ \\
\hline C7-C15-H15A & 109.5 & $\mathrm{C} 3-\mathrm{O} 1-\mathrm{Si} 1$ & $127.9(3)$ \\
\hline $\mathrm{C} 7-\mathrm{C} 15-\mathrm{H} 15 \mathrm{~B}$ & 109.5 & $\mathrm{C} 5-\mathrm{O} 2-\mathrm{H} 2$ & $117(6)$ \\
\hline $\mathrm{H} 15 \mathrm{~A}-\mathrm{C} 15-\mathrm{H} 15 \mathrm{~B}$ & 109.5 & $\mathrm{C} 7-\mathrm{O} 3-\mathrm{C} 8$ & $113.0(4)$ \\
\hline
\end{tabular}


Table S5 (Continued)

\begin{tabular}{|c|c|c|c|}
\hline C7-C15-H15C & 109.5 & $\mathrm{~N} 1-\mathrm{O} 4-\mathrm{C} 4$ & $104.0(3)$ \\
\hline $\mathrm{H} 15 \mathrm{~A}-\mathrm{C} 15-\mathrm{H} 15 \mathrm{C}$ & 109.5 & $\mathrm{O} 1-\mathrm{Si} 1-\mathrm{C} 22$ & $103.0(2)$ \\
\hline $\mathrm{H} 15 \mathrm{~B}-\mathrm{C} 15-\mathrm{H} 15 \mathrm{C}$ & 109.5 & $\mathrm{O} 1-\mathrm{Si} 1-\mathrm{C} 19$ & $114.1(2)$ \\
\hline $\mathrm{C} 17-\mathrm{C} 16-\mathrm{C} 18$ & $109.8(4)$ & C22-Si1-C19 & $113.2(2)$ \\
\hline $\mathrm{C} 17-\mathrm{C} 16-\mathrm{Si} 1$ & $112.5(3)$ & $\mathrm{O} 1-\mathrm{Si} 1-\mathrm{C} 16$ & $107.2(2)$ \\
\hline $\mathrm{C} 18-\mathrm{C} 16-\mathrm{Si} 1$ & $115.0(4)$ & $\mathrm{C} 22-\mathrm{Si} 1-\mathrm{C} 16$ & $110.3(2)$ \\
\hline $\mathrm{C} 17-\mathrm{C} 16-\mathrm{H} 16$ & 106.3 & $\mathrm{C} 19-\mathrm{Si} 1-\mathrm{C} 16$ & $108.7(2)$ \\
\hline $\mathrm{O} 1-\mathrm{C} 3-\mathrm{C} 4-\mathrm{O} 4$ & $179.1(3)$ & $\mathrm{C} 2-\mathrm{C} 3-\mathrm{O} 1-\mathrm{Si} 1$ & $-84.3(5)$ \\
\hline $\mathrm{C} 2-\mathrm{C} 3-\mathrm{C} 4-\mathrm{O} 4$ & $57.6(5)$ & $\mathrm{C} 4-\mathrm{C} 3-\mathrm{O} 1-\mathrm{Si} 1$ & $155.9(3)$ \\
\hline $\mathrm{O} 1-\mathrm{C} 3-\mathrm{C} 4-\mathrm{C} 5$ & $-63.8(5)$ & $\mathrm{C} 6-\mathrm{C} 7-\mathrm{O} 3-\mathrm{C} 8$ & $73.1(5)$ \\
\hline $\mathrm{C} 2-\mathrm{C} 3-\mathrm{C} 4-\mathrm{C} 5$ & 174.7 (4) & $\mathrm{C} 15-\mathrm{C} 7-\mathrm{O} 3-\mathrm{C} 8$ & $-165.7(4)$ \\
\hline $\mathrm{O} 4-\mathrm{C} 4-\mathrm{C} 5-\mathrm{O} 2$ & $91.9(5)$ & $\mathrm{C} 9-\mathrm{C} 8-\mathrm{O} 3-\mathrm{C} 7$ & $-156.6(4)$ \\
\hline $\mathrm{C} 3-\mathrm{C} 4-\mathrm{C} 5-\mathrm{O} 2$ & $-26.3(6)$ & $\mathrm{O} 5-\mathrm{N} 1-\mathrm{O} 4-\mathrm{C} 4$ & $170.6(4)$ \\
\hline $\mathrm{O} 4-\mathrm{C} 4-\mathrm{C} 5-\mathrm{C} 6$ & $-26.8(5)$ & $\mathrm{C} 6-\mathrm{N} 1-\mathrm{O} 4-\mathrm{C} 4$ & $-12.0(5)$ \\
\hline $\mathrm{C} 3-\mathrm{C} 4-\mathrm{C} 5-\mathrm{C} 6$ & $-145.0(4)$ & $\mathrm{C} 3-\mathrm{C} 4-\mathrm{O} 4-\mathrm{N} 1$ & $147.5(3)$ \\
\hline $\mathrm{O} 2-\mathrm{C} 5-\mathrm{C} 6-\mathrm{N} 1$ & $-103.3(5)$ & $\mathrm{C} 5-\mathrm{C} 4-\mathrm{O} 4-\mathrm{N} 1$ & $24.3(5)$ \\
\hline $\mathrm{C} 4-\mathrm{C} 5-\mathrm{C} 6-\mathrm{N} 1$ & $20.4(5)$ & $\mathrm{C} 3-\mathrm{O} 1-\mathrm{Si} 1-\mathrm{C} 22$ & $-149.6(3)$ \\
\hline $\mathrm{O} 2-\mathrm{C} 5-\mathrm{C} 6-\mathrm{C} 7$ & $69.8(6)$ & C3-O1-Si1-C19 & $-26.4(4)$ \\
\hline $\mathrm{C} 4-\mathrm{C} 5-\mathrm{C} 6-\mathrm{C} 7$ & $-166.5(5)$ & $\mathrm{C} 3-\mathrm{O} 1-\mathrm{Si} 1-\mathrm{C} 16$ & $94.0(4)$ \\
\hline $\mathrm{N} 1-\mathrm{C} 6-\mathrm{C} 7-\mathrm{O} 3$ & $-162.7(5)$ & $\mathrm{C} 23-\mathrm{C} 22-\mathrm{Si} 1-\mathrm{O} 1$ & $170.0(4)$ \\
\hline $\mathrm{C} 5-\mathrm{C} 6-\mathrm{C} 7-\mathrm{O} 3$ & $24.8(7)$ & $\mathrm{C} 24-\mathrm{C} 22-\mathrm{Si} 1-\mathrm{O} 1$ & $43.5(4)$ \\
\hline $\mathrm{N} 1-\mathrm{C} 6-\mathrm{C} 7-\mathrm{C} 15$ & $79.2(6)$ & $\mathrm{C} 23-\mathrm{C} 22-\mathrm{Si} 1-\mathrm{C} 19$ & $46.3(5)$ \\
\hline $\mathrm{C} 5-\mathrm{C} 6-\mathrm{C} 7-\mathrm{C} 15$ & $-93.3(6)$ & $\mathrm{C} 24-\mathrm{C} 22-\mathrm{Si} 1-\mathrm{C} 19$ & $-80.2(4)$ \\
\hline $\mathrm{O} 3-\mathrm{C} 8-\mathrm{C} 9-\mathrm{C} 10$ & $26.4(6)$ & $\mathrm{C} 23-\mathrm{C} 22-\mathrm{Si} 1-\mathrm{C} 16$ & $-75.8(5)$ \\
\hline $\mathrm{O} 3-\mathrm{C} 8-\mathrm{C} 9-\mathrm{C} 14$ & $-158.1(4)$ & $\mathrm{C} 24-\mathrm{C} 22-\mathrm{Si} 1-\mathrm{C} 16$ & $157.7(4)$ \\
\hline $\mathrm{C} 14-\mathrm{C} 9-\mathrm{C} 10-\mathrm{C} 11$ & $0.3(7)$ & $\mathrm{C} 21-\mathrm{C} 19-\mathrm{Si} 1-\mathrm{O} 1$ & $-67.6(4)$ \\
\hline $\mathrm{C} 8-\mathrm{C} 9-\mathrm{C} 10-\mathrm{C} 11$ & $175.7(5)$ & $\mathrm{C} 20-\mathrm{C} 19-\mathrm{Si} 1-\mathrm{O} 1$ & $63.1(4)$ \\
\hline $\mathrm{C} 9-\mathrm{C} 10-\mathrm{C} 11-\mathrm{C} 12$ & $-1.3(8)$ & $\mathrm{C} 21-\mathrm{C} 19-\mathrm{Si} 1-\mathrm{C} 22$ & $49.8(4)$ \\
\hline $\mathrm{C} 10-\mathrm{C} 11-\mathrm{C} 12-\mathrm{C} 13$ & $1.4(9)$ & $\mathrm{C} 20-\mathrm{C} 19-\mathrm{Si} 1-\mathrm{C} 22$ & $-179.5(3)$ \\
\hline $\mathrm{C} 11-\mathrm{C} 12-\mathrm{C} 13-\mathrm{C} 14$ & $-0.6(8)$ & $\mathrm{C} 21-\mathrm{C} 19-\mathrm{Si} 1-\mathrm{C} 16$ & $172.8(4)$ \\
\hline $\mathrm{C} 10-\mathrm{C} 9-\mathrm{C} 14-\mathrm{C} 13$ & $0.5(7)$ & $\mathrm{C} 20-\mathrm{C} 19-\mathrm{Si} 1-\mathrm{C} 16$ & $-56.5(4)$ \\
\hline $\mathrm{C} 8-\mathrm{C} 9-\mathrm{C} 14-\mathrm{C} 13$ & $-175.1(5)$ & $\mathrm{C} 17-\mathrm{C} 16-\mathrm{Si} 1-\mathrm{O} 1$ & $64.1(4)$ \\
\hline $\mathrm{C} 12-\mathrm{C} 13-\mathrm{C} 14-\mathrm{C} 9$ & $-0.3(8)$ & $\mathrm{C} 18-\mathrm{C} 16-\mathrm{Si} 1-\mathrm{O} 1$ & $-169.2(4)$ \\
\hline $\mathrm{C} 5-\mathrm{C} 6-\mathrm{N} 1-\mathrm{O} 5$ & $170.6(5)$ & $\mathrm{C} 17-\mathrm{C} 16-\mathrm{Si} 1-\mathrm{C} 22$ & $-47.4(5)$ \\
\hline
\end{tabular}


Table S5 (Continued)

\begin{tabular}{|l|l|l|l|}
\hline $\mathrm{C} 7-\mathrm{C} 6-\mathrm{N} 1-\mathrm{O} 5$ & $-3.1(9)$ & $\mathrm{C} 18-\mathrm{C} 16-\mathrm{Si} 1-\mathrm{C} 22$ & $79.3(5)$ \\
\hline $\mathrm{C} 5-\mathrm{C} 6-\mathrm{N} 1-\mathrm{O} 4$ & $-6.2(6)$ & $\mathrm{C} 17-\mathrm{C} 16-\mathrm{Si} 1-\mathrm{C} 19$ & $-172.1(4)$ \\
\hline $\mathrm{C} 7-\mathrm{C} 6-\mathrm{N} 1-\mathrm{O} 4$ & $-179.9(4)$ & $\mathrm{C} 18-\mathrm{C} 16-\mathrm{Si} 1-\mathrm{C} 19$ & $-45.4(5)$ \\
\hline
\end{tabular}

Table S6. Hydrogen-bond parameters

\begin{tabular}{|l|l|l|l|l|}
\hline$D-\mathrm{H} \cdots A$ & $D-\mathrm{H}(\AA)$ & $\mathrm{H} \cdots A(\AA)$ & $D \cdots A(\AA)$ & $D-\mathrm{H} \cdots A\left({ }^{\circ}\right)$ \\
\hline $\mathrm{O} 2-\mathrm{H} 2 \cdots \mathrm{O} 5^{\mathrm{i}}$ & $0.84(8)$ & $1.97(8)$ & $2.798(5)$ & $167(8)$ \\
\hline
\end{tabular}

Symmetry code(s): (i) $-x+1, y-1 / 2,-z+1$.

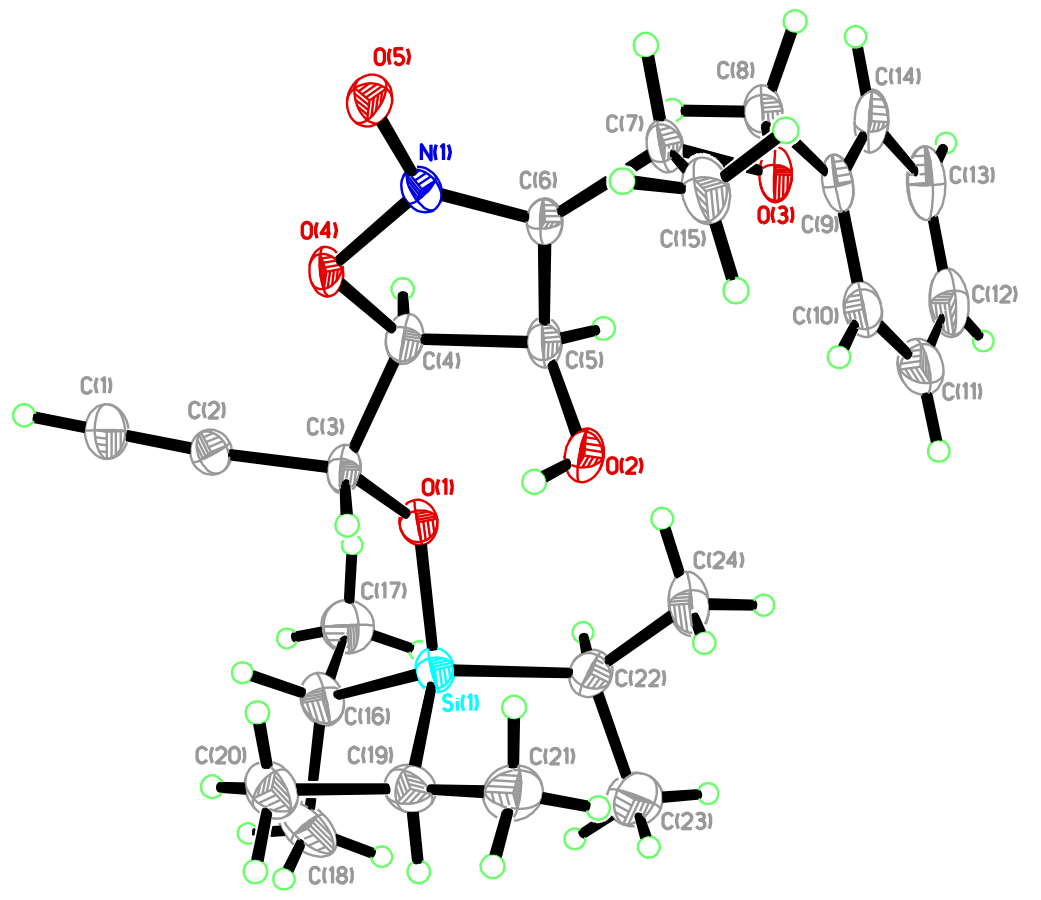

Figure S3. Perspective views showing 50\% probability displacement 


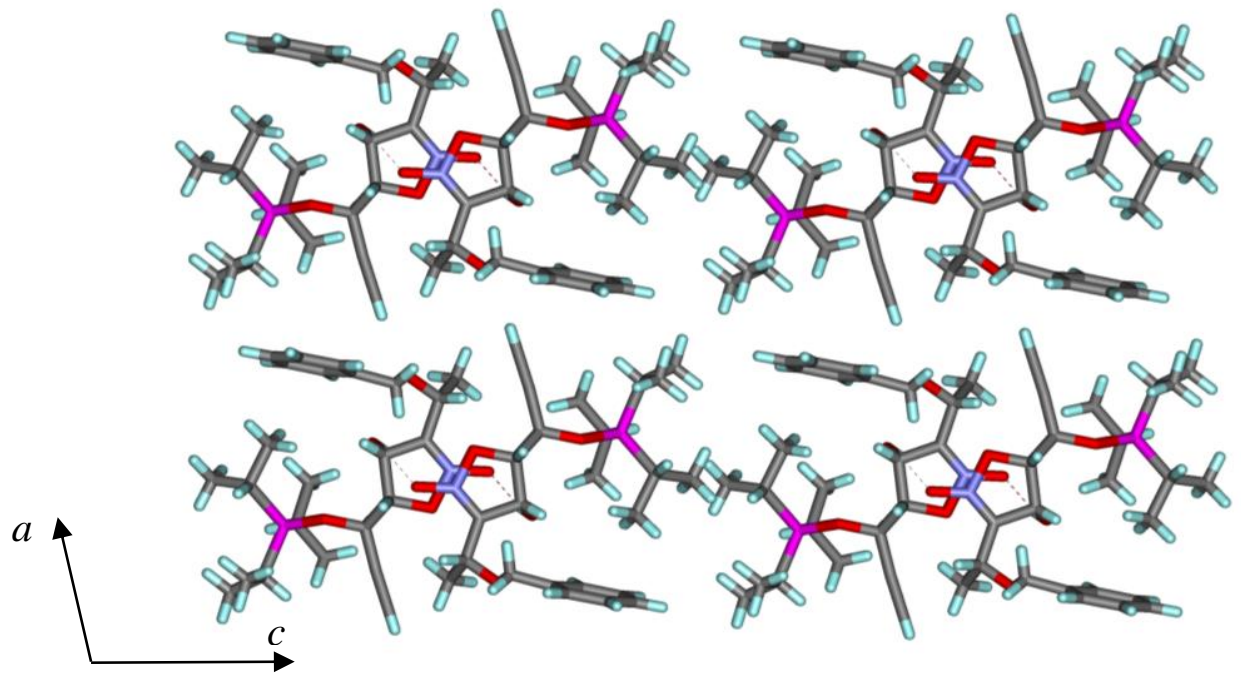

Figure S4. Three-dimensional supramolecular architecture viewed along the $b$-axis direction. 


\section{Crystallographic Data for Compound 31}

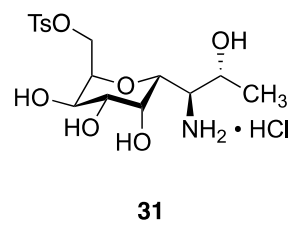

Table S7. Experimental details

\begin{tabular}{|c|c|}
\hline \multicolumn{2}{|l|}{ CCDC Deposition Number 2072281} \\
\hline Chemical formula & $\mathrm{C}_{16} \mathrm{H}_{26} \mathrm{ClNO}_{8} \mathrm{~S}$ \\
\hline$M_{\mathrm{r}}$ & 427.89 \\
\hline Crystal system, space group & Monoclinic, $P 2_{1}$ \\
\hline Temperature $(\mathrm{K})$ & 100 \\
\hline$a, b, c(\AA)$ & $6.0507(3), 9.9307(4), 16.3874(7)$ \\
\hline$\beta\left(\left(^{\circ}\right)\right.$ & $97.2807(15)$ \\
\hline$V\left(\AA^{3}\right)$ & $976.74(8)$ \\
\hline$Z$ & 2 \\
\hline Radiation type & Mo $K \alpha$ \\
\hline$\mu\left(\mathrm{mm}^{-1}\right)$ & 0.35 \\
\hline Crystal size (mm) & $0.20 \times 0.12 \times 0.06$ \\
\hline \multicolumn{2}{|l|}{ Data collection } \\
\hline Diffractometer & Bruker D8 goniometer with CCD area detector \\
\hline Absorption correction & $\begin{array}{l}\text { Multi-scan } \\
S A D A B S\end{array}$ \\
\hline$T_{\min }, T_{\max }$ & $0.806,0.862$ \\
\hline $\begin{array}{l}\text { No. of measured, independent and } \\
\text { observed }[I>2 \sigma(I)] \text { reflections }\end{array}$ & $7929,4202,3942$ \\
\hline$R_{\text {int }}$ & 0.020 \\
\hline$(\sin \theta / \lambda)_{\max }\left(\AA^{-1}\right)$ & 0.641 \\
\hline \multicolumn{2}{|l|}{ Refinement } \\
\hline$R\left[F^{2}>2 \sigma\left(F^{2}\right)\right], w R\left(F^{2}\right), S$ & $0.032,0.067,1.08$ \\
\hline No. of reflections & 4202 \\
\hline No. of parameters & 274 \\
\hline No. of restraints & 1 \\
\hline
\end{tabular}


Table S7 (Continued)

\begin{tabular}{|l|l|}
\hline $\mathrm{H}$-atom treatment & H atoms treated by a mixture of independent and constrained refinement \\
\hline$\Delta \rho_{\max }, \Delta \rho_{\min }\left(\mathrm{e} \AA^{-3}\right)$ & $0.22,-0.29$ \\
\hline Absolute structure & $\begin{array}{l}\text { Flack x determined using } 1719 \text { quotients [(I+)-(I-)]/[(I+)+(I-)] (Parsons, } \\
\text { Flack and Wagner, Acta Cryst. B69 (2013) 249-259). }\end{array}$ \\
\hline Absolute structure parameter & $-0.02(2)$ \\
\hline
\end{tabular}

Computer programs: APEX3 v2016.1-0 (Bruker-AXS, 2016), SAINT 8.37A (Bruker-AXS, 2016),

SHELXT2014 (Sheldrick, 2015), SHELXL2014 (Sheldrick, 2015), Bruker SHELXTL (Sheldrick, 2015).

Table S8. Geometric parameters $\left(\stackrel{\AA}{\AA}{ }^{\circ}\right)$

\begin{tabular}{|l|l|l|l|}
\hline $\mathrm{S} 1-\mathrm{O} 8$ & $1.428(2)$ & $\mathrm{C} 4-\mathrm{C} 5$ & $1.524(4)$ \\
\hline $\mathrm{S} 1-\mathrm{O} 7$ & $1.434(2)$ & $\mathrm{C} 4-\mathrm{H} 4 \mathrm{~A}$ & 1.0000 \\
\hline $\mathrm{S} 1-\mathrm{O} 6$ & $1.578(2)$ & $\mathrm{C} 5-\mathrm{C} 6$ & $1.531(4)$ \\
\hline $\mathrm{S} 1-\mathrm{C} 10$ & $1.747(3)$ & $\mathrm{C} 5-\mathrm{H} 5 \mathrm{~A}$ & 1.0000 \\
\hline $\mathrm{O} 1-\mathrm{C} 2$ & $1.428(3)$ & $\mathrm{C} 6-\mathrm{C} 7$ & $1.506(4)$ \\
\hline $\mathrm{O} 1-\mathrm{H} 1$ & $0.72(4)$ & $\mathrm{C} 6-\mathrm{H} 6$ & 1.0000 \\
\hline O2-C8 & $1.435(3)$ & $\mathrm{C} 7-\mathrm{C} 8$ & $1.524(4)$ \\
\hline $\mathrm{O} 2-\mathrm{C} 4$ & $1.435(3)$ & $\mathrm{C} 7-\mathrm{H} 7$ & 1.0000 \\
\hline $\mathrm{O} 3-\mathrm{C} 5$ & $1.432(3)$ & $\mathrm{C} 8-\mathrm{C} 9$ & $1.525(4)$ \\
\hline $\mathrm{O} 3-\mathrm{H} 3$ & $0.74(4)$ & $\mathrm{C} 8-\mathrm{H} 8$ & 1.0000 \\
\hline $\mathrm{O} 4-\mathrm{C} 6$ & $1.430(3)$ & $\mathrm{C} 9-\mathrm{H} 9 \mathrm{~A}$ & 0.9900 \\
\hline $\mathrm{O} 4-\mathrm{H} 4$ & $0.76(4)$ & $\mathrm{C} 9-\mathrm{H} 9 \mathrm{~B}$ & 0.9900 \\
\hline $\mathrm{O} 5-\mathrm{C} 7$ & $1.431(3)$ & $\mathrm{C} 10-\mathrm{C} 11$ & $1.387(4)$ \\
\hline $\mathrm{O} 5-\mathrm{H} 5$ & $0.73(4)$ & $\mathrm{C} 10-\mathrm{C} 15$ & $1.394(4)$ \\
\hline $\mathrm{O} 6-\mathrm{C} 9$ & $1.471(3)$ & $\mathrm{C} 11-\mathrm{C} 12$ & $1.387(4)$ \\
\hline $\mathrm{N} 1-\mathrm{C} 3$ & $1.491(4)$ & $\mathrm{C} 11-\mathrm{H} 11$ & 0.9500 \\
\hline $\mathrm{N} 1-\mathrm{H} 1 \mathrm{~A}$ & $0.84(4)$ & $\mathrm{C} 12-\mathrm{C} 13$ & $1.387(5)$ \\
\hline $\mathrm{N} 1-\mathrm{H} 1 \mathrm{~B}$ & $0.91(4)$ & $\mathrm{C} 12-\mathrm{H} 12$ & 0.9500 \\
\hline $\mathrm{N} 1-\mathrm{H} 1 \mathrm{C}$ & $0.90(4)$ & $\mathrm{C} 13-\mathrm{C} 14$ & $1.391(5)$ \\
\hline $\mathrm{C} 1-\mathrm{C} 2$ & $1.513(4)$ & $\mathrm{C} 13-\mathrm{C} 16$ & $1.505(4)$ \\
\hline $\mathrm{C} 1-\mathrm{H} 1 \mathrm{D}$ & 0.9800 & $1.383(4)$ \\
\hline
\end{tabular}


Table S8 (Continued)

\begin{tabular}{|c|c|c|c|}
\hline $\mathrm{C} 1-\mathrm{H} 1 \mathrm{E}$ & 0.9800 & C14-H14 & 0.9500 \\
\hline $\mathrm{C} 1-\mathrm{H} 1 \mathrm{~F}$ & 0.9800 & $\mathrm{C} 15-\mathrm{H} 15$ & 0.9500 \\
\hline $\mathrm{C} 2-\mathrm{C} 3$ & $1.525(4)$ & C16-H16A & 0.9800 \\
\hline $\mathrm{C} 2-\mathrm{H} 2$ & 1.0000 & C16-H16B & 0.9800 \\
\hline $\mathrm{C} 3-\mathrm{C} 4$ & $1.530(4)$ & $\mathrm{C} 16-\mathrm{H} 16 \mathrm{C}$ & 0.9800 \\
\hline $\mathrm{C} 3-\mathrm{H} 3 \mathrm{~A}$ & 1.0000 & & \\
\hline $\mathrm{O} 8-\mathrm{S} 1-\mathrm{O} 7$ & $119.62(15)$ & $\mathrm{O} 4-\mathrm{C} 6-\mathrm{C} 7$ & $110.6(2)$ \\
\hline $\mathrm{O} 8-\mathrm{S} 1-\mathrm{O} 6$ & $103.82(12)$ & $\mathrm{O} 4-\mathrm{C} 6-\mathrm{C} 5$ & $107.8(2)$ \\
\hline $\mathrm{O} 7-\mathrm{S} 1-\mathrm{O} 6$ & $108.86(12)$ & $\mathrm{C} 7-\mathrm{C} 6-\mathrm{C} 5$ & $111.2(2)$ \\
\hline $\mathrm{O} 8-\mathrm{S} 1-\mathrm{C} 10$ & $110.90(14)$ & $\mathrm{O} 4-\mathrm{C} 6-\mathrm{H} 6$ & 109.1 \\
\hline $\mathrm{O} 7-\mathrm{S} 1-\mathrm{C} 10$ & $109.04(15)$ & C7-C6-H6 & 109.1 \\
\hline $\mathrm{O} 6-\mathrm{S} 1-\mathrm{C} 10$ & $103.23(12)$ & $\mathrm{C} 5-\mathrm{C} 6-\mathrm{H} 6$ & 109.1 \\
\hline $\mathrm{C} 2-\mathrm{O} 1-\mathrm{H} 1$ & $108(3)$ & $\mathrm{O} 5-\mathrm{C} 7-\mathrm{C} 6$ & $108.3(2)$ \\
\hline $\mathrm{C} 8-\mathrm{O} 2-\mathrm{C} 4$ & $115.4(2)$ & $\mathrm{O} 5-\mathrm{C} 7-\mathrm{C} 8$ & $111.0(2)$ \\
\hline $\mathrm{C} 5-\mathrm{O} 3-\mathrm{H} 3$ & $106(3)$ & $\mathrm{C} 6-\mathrm{C} 7-\mathrm{C} 8$ & $111.7(2)$ \\
\hline $\mathrm{C} 6-\mathrm{O} 4-\mathrm{H} 4$ & $106(3)$ & $\mathrm{O} 5-\mathrm{C} 7-\mathrm{H} 7$ & 108.6 \\
\hline $\mathrm{C} 7-\mathrm{O} 5-\mathrm{H} 5$ & $105(3)$ & C6- $-\mathrm{C} 7-\mathrm{H} 7$ & 108.6 \\
\hline $\mathrm{C} 9-\mathrm{O} 6-\mathrm{S} 1$ & $117.63(16)$ & $\mathrm{C} 8-\mathrm{C} 7-\mathrm{H} 7$ & 108.6 \\
\hline $\mathrm{C} 3-\mathrm{N} 1-\mathrm{H} 1 \mathrm{~A}$ & $110(2)$ & $\mathrm{O} 2-\mathrm{C} 8-\mathrm{C} 7$ & $110.2(2)$ \\
\hline $\mathrm{C} 3-\mathrm{N} 1-\mathrm{H} 1 \mathrm{~B}$ & $112(2)$ & $\mathrm{O} 2-\mathrm{C} 8-\mathrm{C} 9$ & $111.7(2)$ \\
\hline $\mathrm{H} 1 \mathrm{~A}-\mathrm{N} 1-\mathrm{H} 1 \mathrm{~B}$ & $106(3)$ & $\mathrm{C} 7-\mathrm{C} 8-\mathrm{C} 9$ & $113.3(2)$ \\
\hline $\mathrm{C} 3-\mathrm{N} 1-\mathrm{H} 1 \mathrm{C}$ & $114(2)$ & $\mathrm{O} 2-\mathrm{C} 8-\mathrm{H} 8$ & 107.1 \\
\hline $\mathrm{H} 1 \mathrm{~A}-\mathrm{N} 1-\mathrm{H} 1 \mathrm{C}$ & $109(3)$ & $\mathrm{C} 7-\mathrm{C} 8-\mathrm{H} 8$ & 107.1 \\
\hline $\mathrm{H} 1 \mathrm{~B}-\mathrm{N} 1-\mathrm{H} 1 \mathrm{C}$ & $107(3)$ & $\mathrm{C} 9-\mathrm{C} 8-\mathrm{H} 8$ & 107.1 \\
\hline $\mathrm{C} 2-\mathrm{C} 1-\mathrm{H} 1 \mathrm{D}$ & 109.5 & $\mathrm{O} 6-\mathrm{C} 9-\mathrm{C} 8$ & $106.3(2)$ \\
\hline $\mathrm{C} 2-\mathrm{C} 1-\mathrm{H} 1 \mathrm{E}$ & 109.5 & $\mathrm{O} 6-\mathrm{C} 9-\mathrm{H} 9 \mathrm{~A}$ & 110.5 \\
\hline $\mathrm{H} 1 \mathrm{D}-\mathrm{C} 1-\mathrm{H} 1 \mathrm{E}$ & 109.5 & $\mathrm{C} 8-\mathrm{C} 9-\mathrm{H} 9 \mathrm{~A}$ & 110.5 \\
\hline $\mathrm{C} 2-\mathrm{C} 1-\mathrm{H} 1 \mathrm{~F}$ & 109.5 & $\mathrm{O} 6-\mathrm{C} 9-\mathrm{H} 9 \mathrm{~B}$ & 110.5 \\
\hline $\mathrm{H} 1 \mathrm{D}-\mathrm{C} 1-\mathrm{H} 1 \mathrm{~F}$ & 109.5 & $\mathrm{C} 8-\mathrm{C} 9-\mathrm{H} 9 \mathrm{~B}$ & 110.5 \\
\hline $\mathrm{H} 1 \mathrm{E}-\mathrm{C} 1-\mathrm{H} 1 \mathrm{~F}$ & 109.5 & $\mathrm{H} 9 \mathrm{~A}-\mathrm{C} 9-\mathrm{H} 9 \mathrm{~B}$ & 108.7 \\
\hline $\mathrm{O} 1-\mathrm{C} 2-\mathrm{C} 1$ & $111.3(2)$ & $\mathrm{C} 11-\mathrm{C} 10-\mathrm{C} 15$ & $120.1(3)$ \\
\hline $\mathrm{O} 1-\mathrm{C} 2-\mathrm{C} 3$ & $107.6(2)$ & $\mathrm{C} 11-\mathrm{C} 10-\mathrm{S} 1$ & $120.1(2)$ \\
\hline $\mathrm{C} 1-\mathrm{C} 2-\mathrm{C} 3$ & $113.5(2)$ & $\mathrm{C} 15-\mathrm{C} 10-\mathrm{S} 1$ & $119.6(2)$ \\
\hline $\mathrm{O} 1-\mathrm{C} 2-\mathrm{H} 2$ & 108.1 & $\mathrm{C} 12-\mathrm{C} 11-\mathrm{C} 10$ & $119.5(3)$ \\
\hline
\end{tabular}


Table S8 (Continued)

\begin{tabular}{|c|c|c|c|}
\hline $\mathrm{C} 1-\mathrm{C} 2-\mathrm{H} 2$ & 108.1 & $\mathrm{C} 12-\mathrm{C} 11-\mathrm{H} 11$ & 120.3 \\
\hline $\mathrm{C} 3-\mathrm{C} 2-\mathrm{H} 2$ & 108.1 & $\mathrm{C} 10-\mathrm{C} 11-\mathrm{H} 11$ & 120.3 \\
\hline $\mathrm{N} 1-\mathrm{C} 3-\mathrm{C} 2$ & $108.6(2)$ & $\mathrm{C} 11-\mathrm{C} 12-\mathrm{C} 13$ & $121.3(3)$ \\
\hline $\mathrm{N} 1-\mathrm{C} 3-\mathrm{C} 4$ & $109.8(2)$ & $\mathrm{C} 11-\mathrm{C} 12-\mathrm{H} 12$ & 119.3 \\
\hline $\mathrm{C} 2-\mathrm{C} 3-\mathrm{C} 4$ & $117.2(2)$ & $\mathrm{C} 13-\mathrm{C} 12-\mathrm{H} 12$ & 119.3 \\
\hline $\mathrm{N} 1-\mathrm{C} 3-\mathrm{H} 3 \mathrm{~A}$ & 106.9 & $\mathrm{C} 12-\mathrm{C} 13-\mathrm{C} 14$ & $118.2(3)$ \\
\hline $\mathrm{C} 2-\mathrm{C} 3-\mathrm{H} 3 \mathrm{~A}$ & 106.9 & $\mathrm{C} 12-\mathrm{C} 13-\mathrm{C} 16$ & $120.7(3)$ \\
\hline $\mathrm{C} 4-\mathrm{C} 3-\mathrm{H} 3 \mathrm{~A}$ & 106.9 & $\mathrm{C} 14-\mathrm{C} 13-\mathrm{C} 16$ & $121.1(3)$ \\
\hline $\mathrm{O} 2-\mathrm{C} 4-\mathrm{C} 5$ & $112.1(2)$ & $\mathrm{C} 15-\mathrm{C} 14-\mathrm{C} 13$ & $121.5(3)$ \\
\hline $\mathrm{O} 2-\mathrm{C} 4-\mathrm{C} 3$ & $102.8(2)$ & $\mathrm{C} 15-\mathrm{C} 14-\mathrm{H} 14$ & 119.3 \\
\hline $\mathrm{C} 5-\mathrm{C} 4-\mathrm{C} 3$ & $117.1(2)$ & $\mathrm{C} 13-\mathrm{C} 14-\mathrm{H} 14$ & 119.3 \\
\hline $\mathrm{O} 2-\mathrm{C} 4-\mathrm{H} 4 \mathrm{~A}$ & 108.1 & $\mathrm{C} 14-\mathrm{C} 15-\mathrm{C} 10$ & $119.2(3)$ \\
\hline $\mathrm{C} 5-\mathrm{C} 4-\mathrm{H} 4 \mathrm{~A}$ & 108.1 & C14-C15-H15 & 120.4 \\
\hline $\mathrm{C} 3-\mathrm{C} 4-\mathrm{H} 4 \mathrm{~A}$ & 108.1 & $\mathrm{C} 10-\mathrm{C} 15-\mathrm{H} 15$ & 120.4 \\
\hline $\mathrm{O} 3-\mathrm{C} 5-\mathrm{C} 4$ & $110.1(2)$ & $\mathrm{C} 13-\mathrm{C} 16-\mathrm{H} 16 \mathrm{~A}$ & 109.5 \\
\hline $\mathrm{O} 3-\mathrm{C} 5-\mathrm{C} 6$ & $109.8(2)$ & $\mathrm{C} 13-\mathrm{C} 16-\mathrm{H} 16 \mathrm{~B}$ & 109.5 \\
\hline $\mathrm{C} 4-\mathrm{C} 5-\mathrm{C} 6$ & $108.0(2)$ & $\mathrm{H} 16 \mathrm{~A}-\mathrm{C} 16-\mathrm{H} 16 \mathrm{~B}$ & 109.5 \\
\hline $\mathrm{O} 3-\mathrm{C} 5-\mathrm{H} 5 \mathrm{~A}$ & 109.6 & $\mathrm{C} 13-\mathrm{C} 16-\mathrm{H} 16 \mathrm{C}$ & 109.5 \\
\hline $\mathrm{C} 4-\mathrm{C} 5-\mathrm{H} 5 \mathrm{~A}$ & 109.6 & $\mathrm{H} 16 \mathrm{~A}-\mathrm{C} 16-\mathrm{H} 16 \mathrm{C}$ & 109.5 \\
\hline $\mathrm{C} 6-\mathrm{C} 5-\mathrm{H} 5 \mathrm{~A}$ & 109.6 & $\mathrm{H} 16 \mathrm{~B}-\mathrm{C} 16-\mathrm{H} 16 \mathrm{C}$ & 109.5 \\
\hline $\mathrm{O} 8-\mathrm{S} 1-\mathrm{O} 6-\mathrm{C} 9$ & $-176.1(2)$ & $\mathrm{C} 4-\mathrm{O} 2-\mathrm{C} 8-\mathrm{C} 7$ & $-54.4(3)$ \\
\hline $\mathrm{O} 7-\mathrm{S} 1-\mathrm{O} 6-\mathrm{C} 9$ & $-47.6(2)$ & $\mathrm{C} 4-\mathrm{O} 2-\mathrm{C} 8-\mathrm{C} 9$ & $72.5(3)$ \\
\hline $\mathrm{C} 10-\mathrm{S} 1-\mathrm{O} 6-\mathrm{C} 9$ & $68.1(2)$ & $\mathrm{O} 5-\mathrm{C} 7-\mathrm{C} 8-\mathrm{O} 2$ & $173.5(2)$ \\
\hline $\mathrm{O} 1-\mathrm{C} 2-\mathrm{C} 3-\mathrm{N} 1$ & $-53.8(3)$ & $\mathrm{C} 6-\mathrm{C} 7-\mathrm{C} 8-\mathrm{O} 2$ & $52.5(3)$ \\
\hline $\mathrm{C} 1-\mathrm{C} 2-\mathrm{C} 3-\mathrm{N} 1$ & $-177.4(2)$ & $\mathrm{O} 5-\mathrm{C} 7-\mathrm{C} 8-\mathrm{C} 9$ & $47.5(3)$ \\
\hline $\mathrm{O} 1-\mathrm{C} 2-\mathrm{C} 3-\mathrm{C} 4$ & $71.3(3)$ & $\mathrm{C} 6-\mathrm{C} 7-\mathrm{C} 8-\mathrm{C} 9$ & $-73.5(3)$ \\
\hline $\mathrm{C} 1-\mathrm{C} 2-\mathrm{C} 3-\mathrm{C} 4$ & $-52.3(3)$ & $\mathrm{S} 1-\mathrm{O} 6-\mathrm{C} 9-\mathrm{C} 8$ & $134.41(19)$ \\
\hline $\mathrm{C} 8-\mathrm{O} 2-\mathrm{C} 4-\mathrm{C} 5$ & $57.4(3)$ & $\mathrm{O} 2-\mathrm{C} 8-\mathrm{C} 9-\mathrm{O} 6$ & $59.8(3)$ \\
\hline $\mathrm{C} 8-\mathrm{O} 2-\mathrm{C} 4-\mathrm{C} 3$ & $-175.9(2)$ & $\mathrm{C} 7-\mathrm{C} 8-\mathrm{C} 9-\mathrm{O} 6$ & $-175.1(2)$ \\
\hline $\mathrm{N} 1-\mathrm{C} 3-\mathrm{C} 4-\mathrm{O} 2$ & $-55.1(3)$ & $\mathrm{O} 8-\mathrm{S} 1-\mathrm{C} 10-\mathrm{C} 11$ & $156.8(2)$ \\
\hline $\mathrm{C} 2-\mathrm{C} 3-\mathrm{C} 4-\mathrm{O} 2$ & $-179.6(2)$ & $\mathrm{O} 7-\mathrm{S} 1-\mathrm{C} 10-\mathrm{C} 11$ & $23.1(3)$ \\
\hline $\mathrm{N} 1-\mathrm{C} 3-\mathrm{C} 4-\mathrm{C} 5$ & $68.3(3)$ & $\mathrm{O} 6-\mathrm{S} 1-\mathrm{C} 10-\mathrm{C} 11$ & $-92.5(2)$ \\
\hline $\mathrm{C} 2-\mathrm{C} 3-\mathrm{C} 4-\mathrm{C} 5$ & $-56.1(3)$ & $\mathrm{O} 8-\mathrm{S} 1-\mathrm{C} 10-\mathrm{C} 15$ & $-27.4(3)$ \\
\hline $\mathrm{O} 2-\mathrm{C} 4-\mathrm{C} 5-\mathrm{O} 3$ & $64.8(3)$ & $\mathrm{O} 7-\mathrm{S} 1-\mathrm{C} 10-\mathrm{C} 15$ & $-161.2(2)$ \\
\hline
\end{tabular}


Table S8 (Continued)

\begin{tabular}{|l|l|l|l|}
\hline $\mathrm{C} 3-\mathrm{C} 4-\mathrm{C} 5-\mathrm{O} 3$ & $-53.7(3)$ & $\mathrm{O} 6-\mathrm{S} 1-\mathrm{C} 10-\mathrm{C} 15$ & $83.2(2)$ \\
\hline $\mathrm{O} 2-\mathrm{C} 4-\mathrm{C} 5-\mathrm{C} 6$ & $-55.1(3)$ & $\mathrm{C} 15-\mathrm{C} 10-\mathrm{C} 11-\mathrm{C} 12$ & $-2.8(4)$ \\
\hline $\mathrm{C} 3-\mathrm{C} 4-\mathrm{C} 5-\mathrm{C} 6$ & $-173.6(2)$ & $\mathrm{S} 1-\mathrm{C} 10-\mathrm{C} 11-\mathrm{C} 12$ & $172.9(2)$ \\
\hline $\mathrm{O} 3-\mathrm{C} 5-\mathrm{C} 6-\mathrm{O} 4$ & $56.1(3)$ & $\mathrm{C} 10-\mathrm{C} 11-\mathrm{C} 12-\mathrm{C} 13$ & $-0.2(4)$ \\
\hline $\mathrm{C} 4-\mathrm{C} 5-\mathrm{C} 6-\mathrm{O} 4$ & $176.1(2)$ & $\mathrm{C} 11-\mathrm{C} 12-\mathrm{C} 13-\mathrm{C} 14$ & $3.9(4)$ \\
\hline $\mathrm{O} 3-\mathrm{C} 5-\mathrm{C} 6-\mathrm{C} 7$ & $-65.3(3)$ & $\mathrm{C} 11-\mathrm{C} 12-\mathrm{C} 13-\mathrm{C} 16$ & $-175.8(3)$ \\
\hline $\mathrm{C} 4-\mathrm{C} 5-\mathrm{C} 6-\mathrm{C} 7$ & $54.7(3)$ & $\mathrm{C} 12-\mathrm{C} 13-\mathrm{C} 14-\mathrm{C} 15$ & $-4.7(4)$ \\
\hline $\mathrm{O} 4-\mathrm{C} 6-\mathrm{C} 7-\mathrm{O} 5$ & $62.9(3)$ & $\mathrm{C} 16-\mathrm{C} 13-\mathrm{C} 14-\mathrm{C} 15$ & $175.0(3)$ \\
\hline $\mathrm{C} 5-\mathrm{C} 6-\mathrm{C} 7-\mathrm{O} 5$ & $-177.4(2)$ & $\mathrm{C} 13-\mathrm{C} 14-\mathrm{C} 15-\mathrm{C} 10$ & $1.7(4)$ \\
\hline $\mathrm{O} 4-\mathrm{C} 6-\mathrm{C} 7-\mathrm{C} 8$ & $-174.6(2)$ & $\mathrm{C} 11-\mathrm{C} 10-\mathrm{C} 15-\mathrm{C} 14$ & $2.1(4)$ \\
\hline $\mathrm{C} 5-\mathrm{C} 6-\mathrm{C} 7-\mathrm{C} 8$ & $-54.8(3)$ & $\mathrm{S} 1-\mathrm{C} 10-\mathrm{C} 15-\mathrm{C} 14$ & $-173.7(2)$ \\
\hline
\end{tabular}

Table S9. Hydrogen-bond parameters

\begin{tabular}{|l|l|l|l|l|}
\hline$D-\mathrm{H} \cdots A$ & $D-\mathrm{H}(\AA)$ & $\mathrm{H} \cdots A(\AA)$ & $D \cdots A(\AA)$ & $D-\mathrm{H} \cdots A\left({ }^{\circ}\right)$ \\
\hline $\mathrm{O} 4-\mathrm{H} 4 \cdots \mathrm{O} 5$ & $0.76(4)$ & $2.55(4)$ & $2.832(3)$ & $104(4)$ \\
\hline $\mathrm{N} 1-\mathrm{H} 1 \mathrm{~B} \cdots \mathrm{O} 1$ & $0.91(4)$ & $2.31(4)$ & $2.737(3)$ & $108(3)$ \\
\hline $\mathrm{N} 1-\mathrm{H} 1 \mathrm{C} \cdots \mathrm{O} 2$ & $0.90(4)$ & $2.29(4)$ & $2.686(3)$ & $107(3)$ \\
\hline $\mathrm{N} 1-\mathrm{H} 1 \mathrm{~B} \cdots \mathrm{O} 3$ & $0.91(4)$ & $2.43(3)$ & $2.789(3)$ & $104(2)$ \\
\hline $\mathrm{O} 1-\mathrm{H} 1 \cdots \mathrm{Cl} 1^{\mathrm{i}}$ & $0.72(4)$ & $2.47(4)$ & $3.155(2)$ & $160(4)$ \\
\hline $\mathrm{O} 3-\mathrm{H} 3 \cdots \mathrm{C} 11^{1 i}$ & $0.74(4)$ & $2.45(4)$ & $3.176(2)$ & $170(5)$ \\
\hline $\mathrm{O} 5-\mathrm{H} 5 \cdots \mathrm{Cl} 1^{\mathrm{iii}}$ & $0.73(4)$ & $2.38(4)$ & $3.108(3)$ & $172(4)$ \\
\hline $\mathrm{N} 1-\mathrm{H} 1 \mathrm{~A} \cdots \mathrm{C} 1^{\mathrm{iv}}$ & $0.84(4)$ & $2.36(4)$ & $3.191(3)$ & $168(3)$ \\
\hline $\mathrm{N} 1-\mathrm{H} 1 \mathrm{~B} \cdots \mathrm{O} 4{ }^{\mathrm{i}}$ & $0.91(4)$ & $2.23(4)$ & $2.847(3)$ & $125(3)$ \\
\hline
\end{tabular}

Symmetry code(s): (i) $-x-1, y+1 / 2,-z$; (ii) $x-1, y, z$; (iii) $-x, y-1 / 2,-z$; (iv) $-x, y+1 / 2,-z$. 


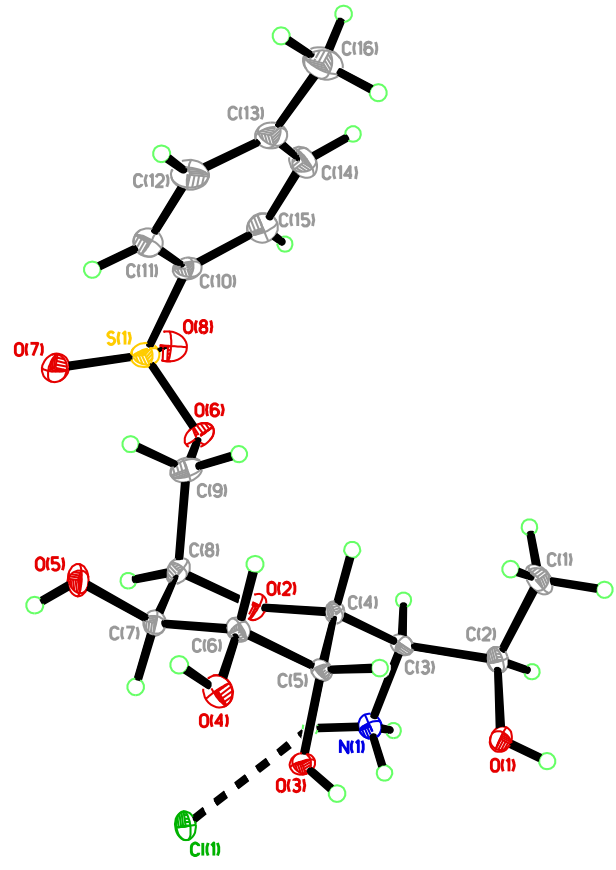

Figure S5. Perspective views showing 50\% probability displacement

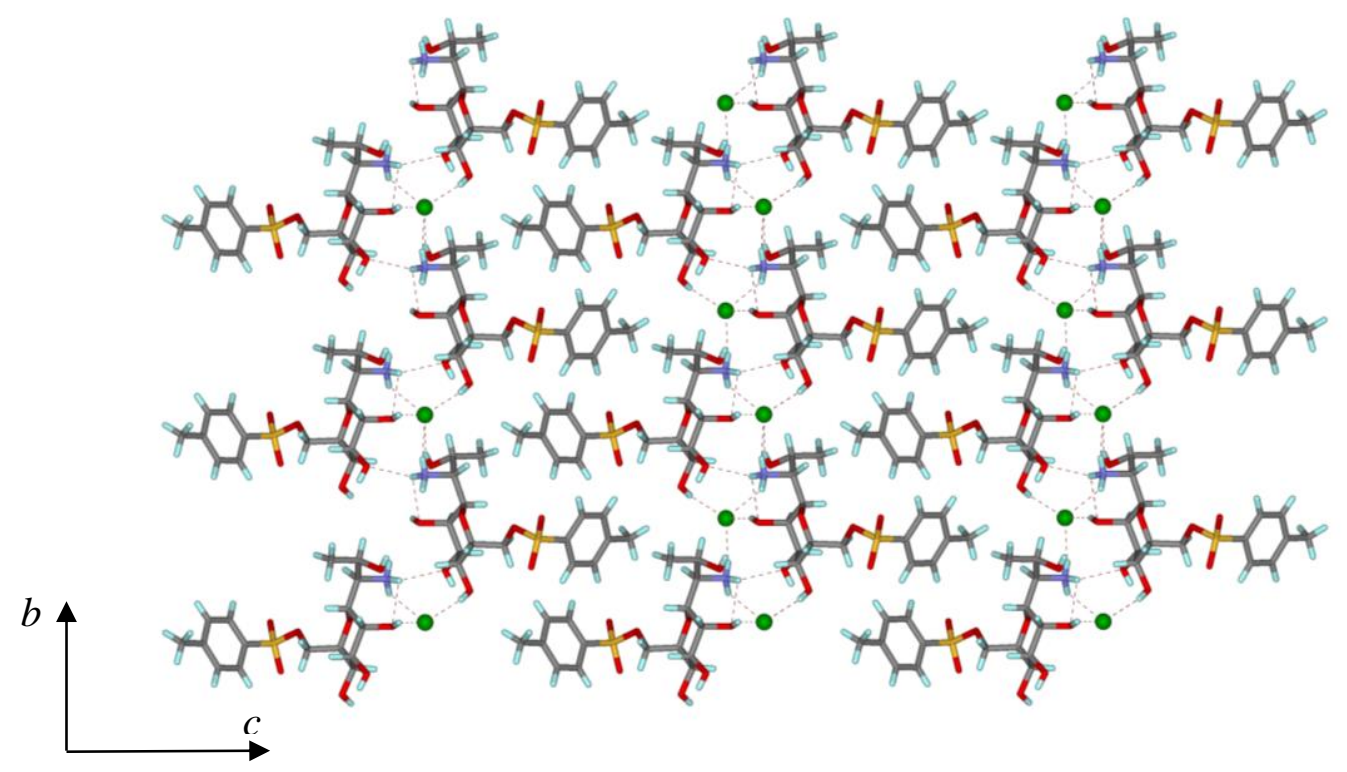

Figure S6. Three-dimensional supramolecular architecture viewed along the $a$-axis direction. 
Catalog of NMR Spectra 

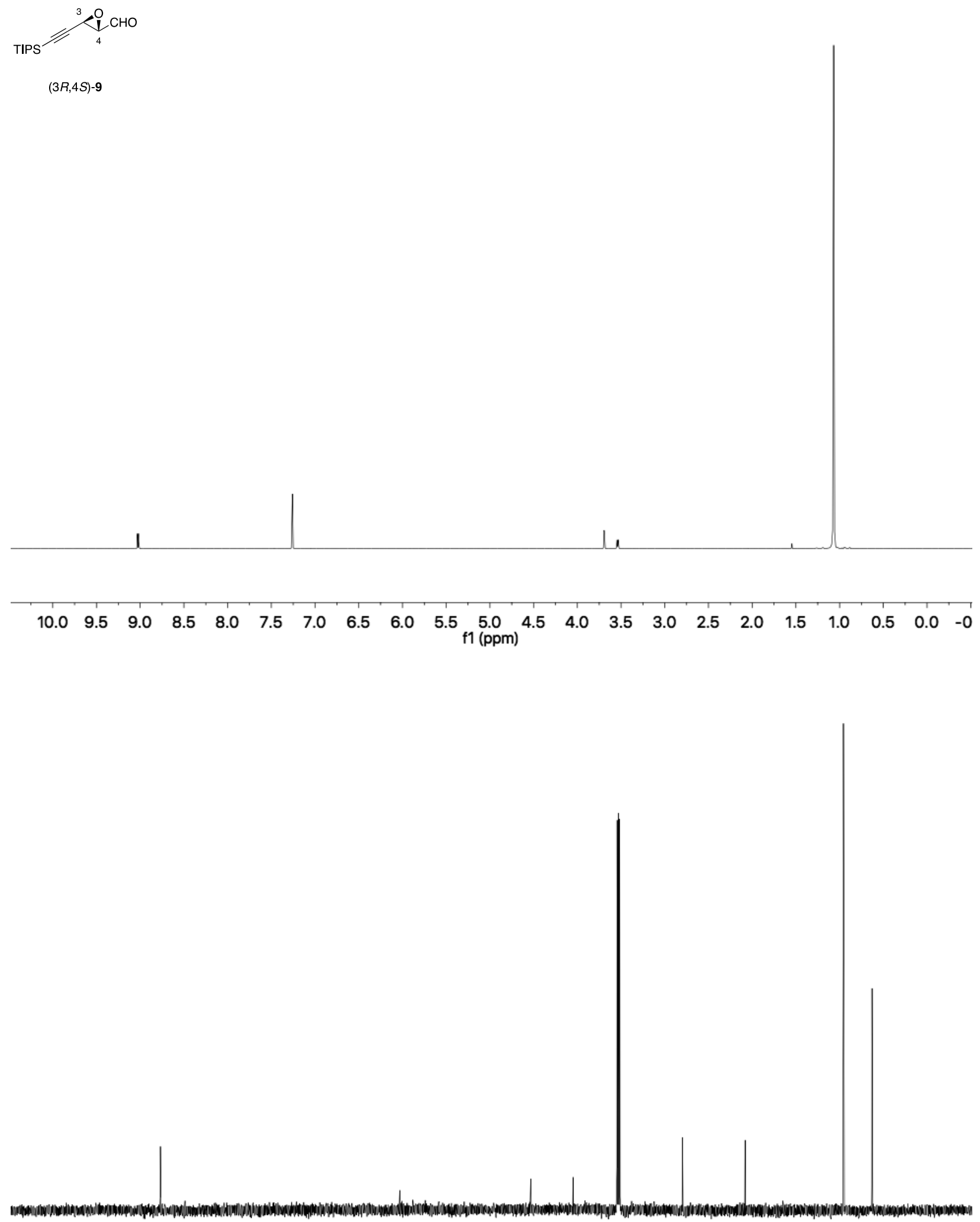

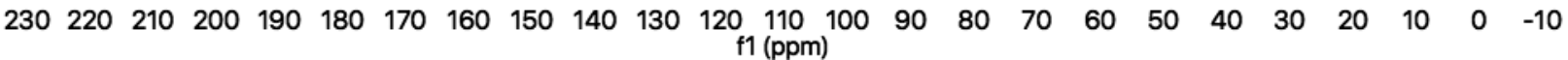




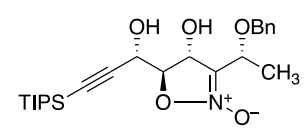

17

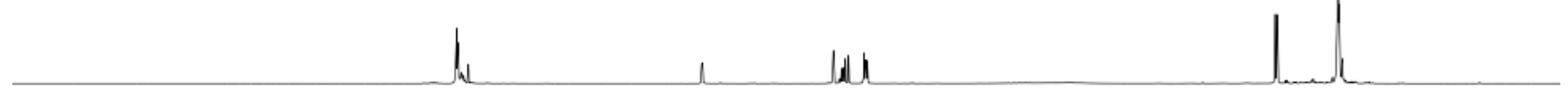

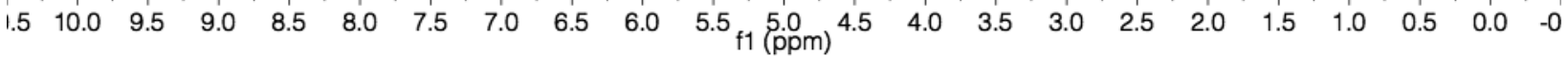

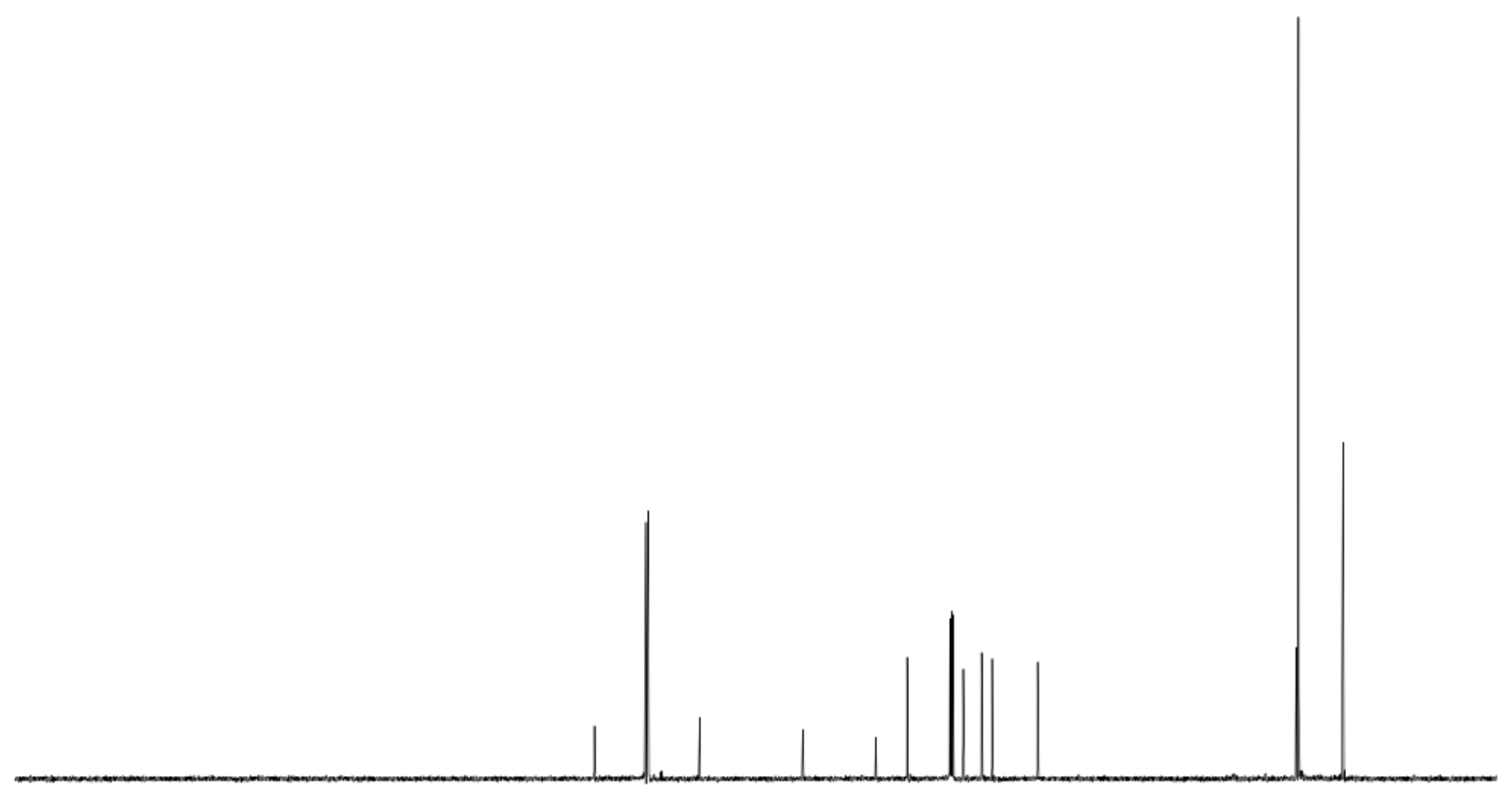

$\begin{array}{lllllllllllllllllllllllll}230 & 220 & 210 & 200 & 190 & 180 & 170 & 160 & 150 & 140 & 130 & 120 & 110 & 100 & 90 & 80 & 70 & 60 & 50 & 40 & 30 & 20 & 10 & 0 & -10\end{array}$ $\mathrm{f} 1(\mathrm{ppm})$ 


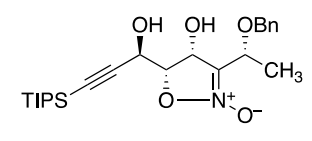

18

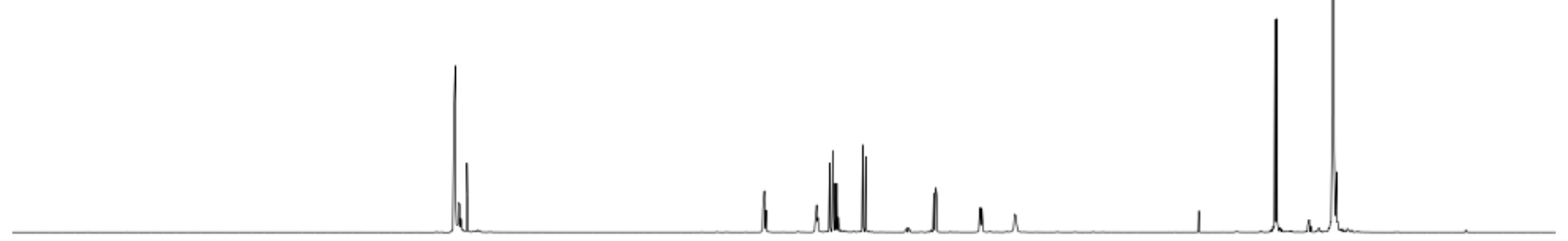

\begin{tabular}{lllllllllllllllllllllllll}
\hline .5 & 10.0 & 9.5 & 9.0 & 8.5 & 8.0 & 7.5 & 7.0 & 6.5 & 6.0 & 5.5 & 5.0 & 4.5 & 4.0 & 3.5 & 3.0 & 2.5 & 2.0 & 1.5 & 1.0 & 0.5 & 0.0 & -0
\end{tabular}

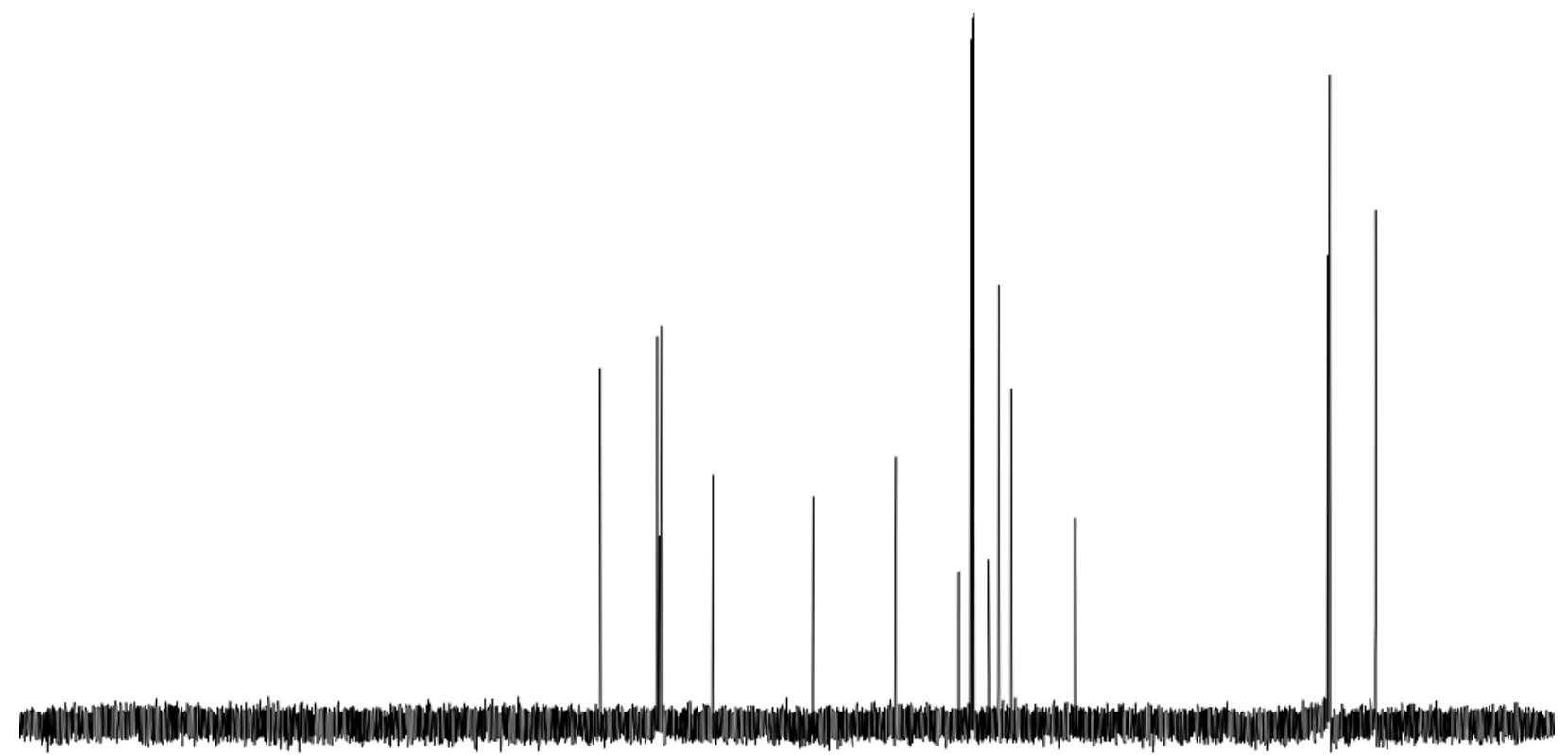

$\begin{array}{llllllllllllllllllllllll}230 & 220 & 210 & 200 & 190 & 180 & 170 & 160 & 150 & 140 & 130 & 120 & \begin{array}{c}110 \\ \mathrm{f} 1(\mathrm{ppm})\end{array} & 90 & 80 & 70 & 60 & 50 & 40 & 30 & 20 & 10 & 0 & -10\end{array}$ 


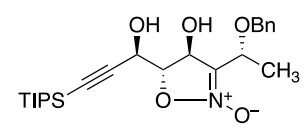

S4
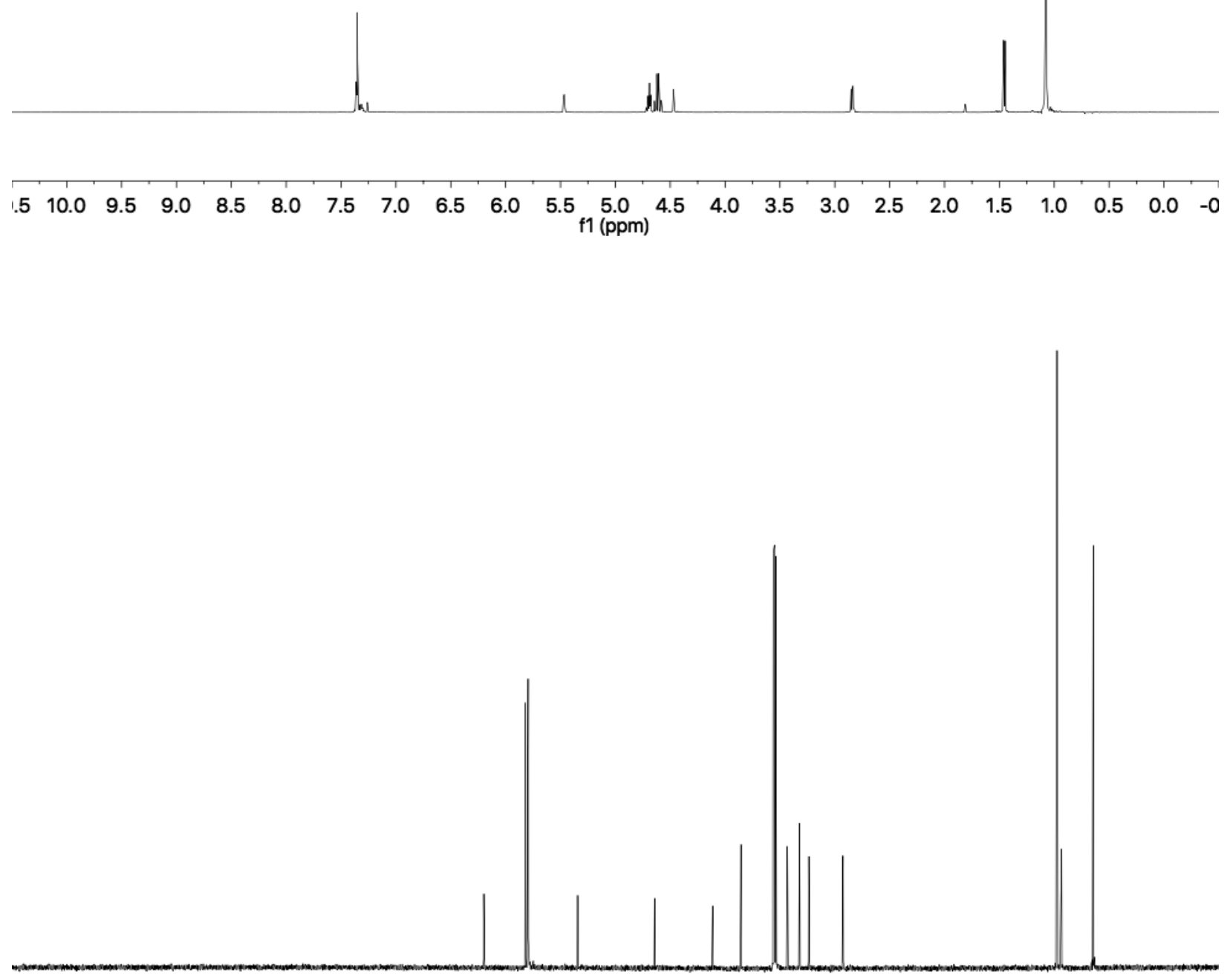

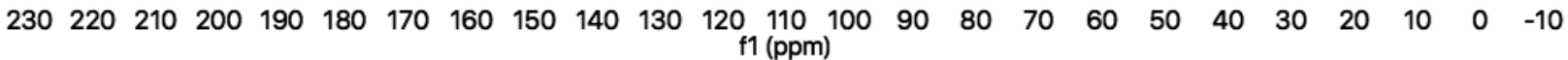




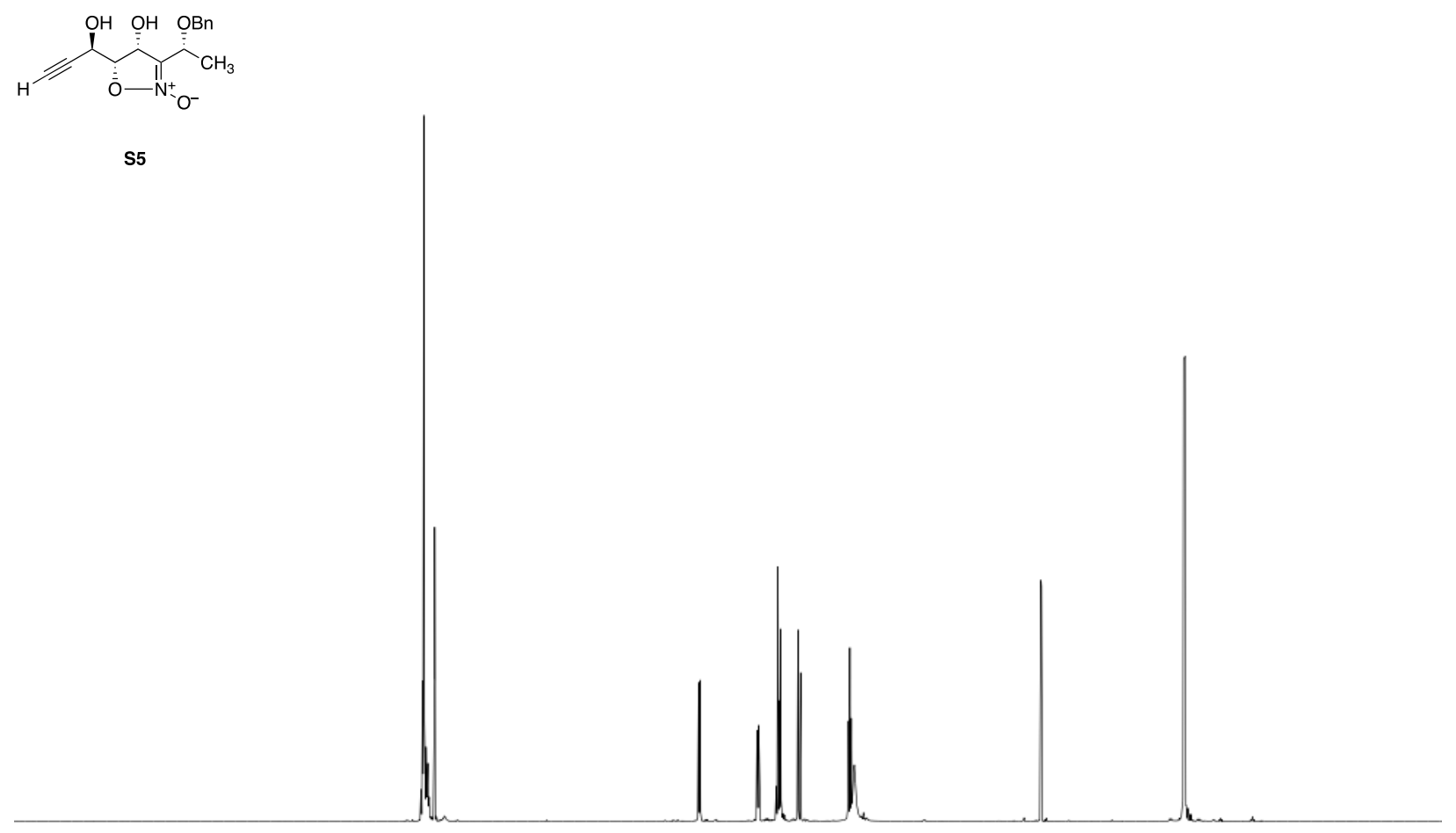

\begin{tabular}{lllllllllllllllllllllll}
\hline .5 & 10.0 & 9.5 & 9.0 & 8.5 & 8.0 & 7.5 & 7.0 & 6.5 & 6.0 & $5.5 \underset{\mathrm{f} 1}{\mathrm{f}} \mathbf{( \mathrm { ppm } )}$ & 4.5 & 4.0 & 3.5 & 3.0 & 2.5 & 2.0 & 1.5 & 1.0 & 0.5 & 0.0 & -0
\end{tabular}

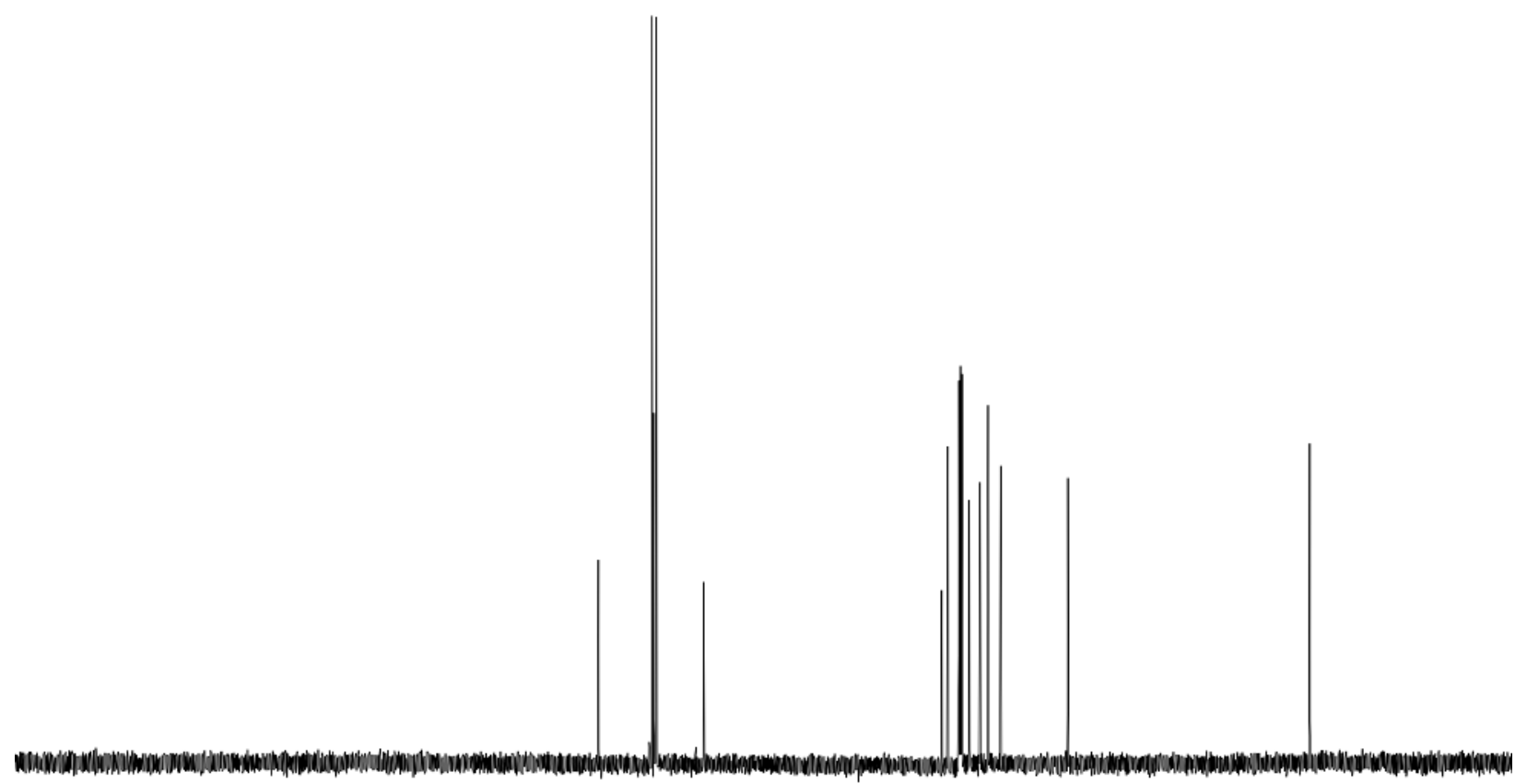

$\begin{array}{lllllllllllllllllllllllll}230 & 220 & 210 & 200 & 190 & 180 & 170 & 160 & 150 & 140 & 130 & 120 \\ \mathrm{f} 1 & 110 \\ (\mathrm{ppm}) & 100 & 90 & 80 & 70 & 60 & 50 & 40 & 30 & 20 & 10 & 0 & -10\end{array}$ 


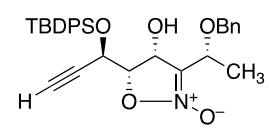

22a

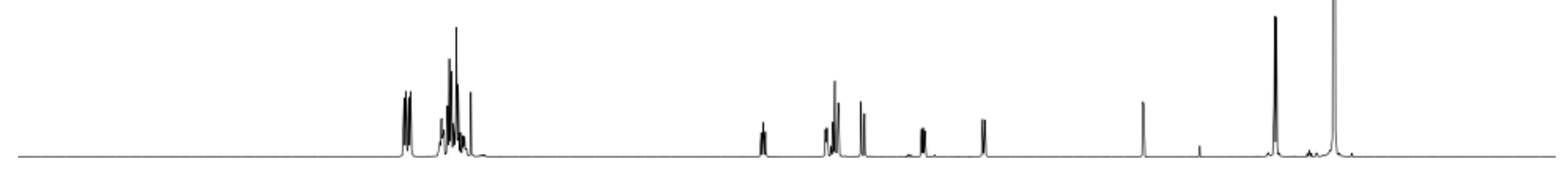

$\begin{array}{lllllllllllllllllllllll}1.5 & 10.0 & 9.5 & 9.0 & 8.5 & 8.0 & 7.5 & 7.0 & 6.5 & 6.0 & 5.5 \underset{\mathrm{f} 1}{\mathrm{f}} \mathbf{( \mathrm { ppm } )} & 4.5 & 4.0 & 3.5 & 3.0 & 2.5 & 2.0 & 1.5 & 1.0 & 0.5 & 0.0 & -0\end{array}$

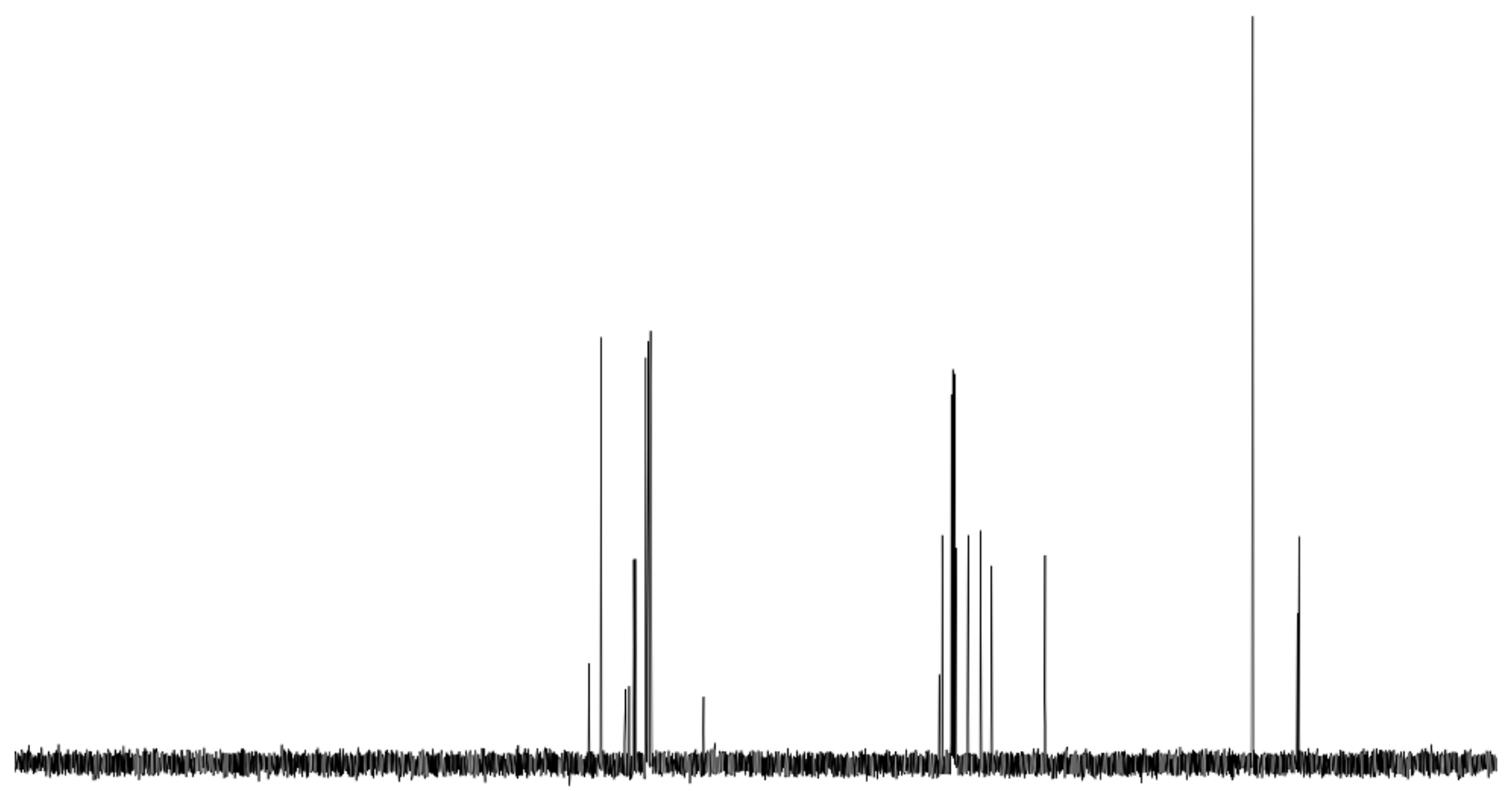

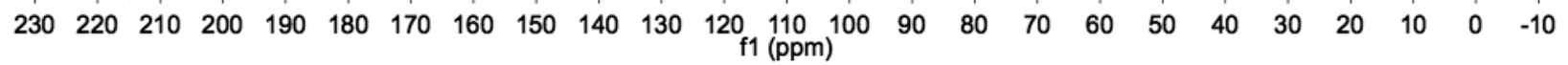




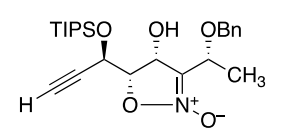

22b

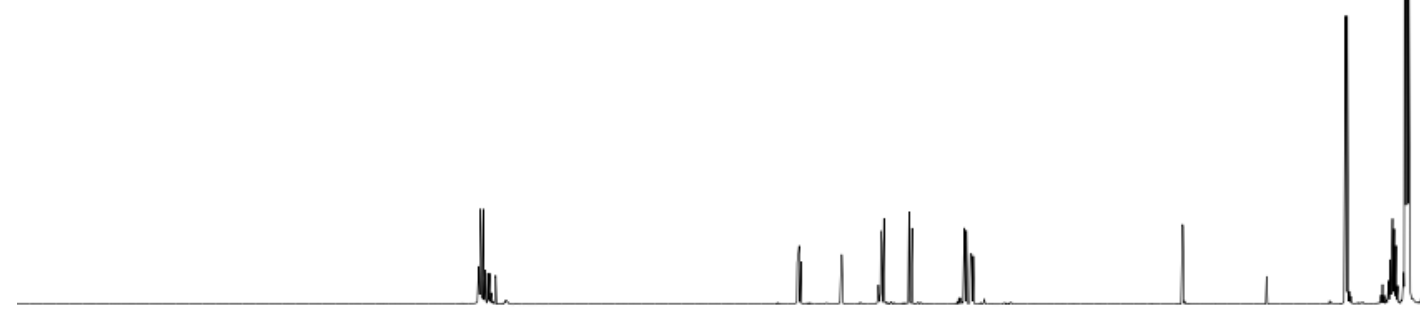

$\begin{array}{lllllllllllllllllllllll}1.5 & 10.0 & 9.5 & 9.0 & 8.5 & 8.0 & 7.5 & 7.0 & 6.5 & 6.0 & 5.5 \underset{\mathrm{f} 1}{(\mathrm{ppm})} \mathbf{5 . 0} & 4.5 & 4.0 & 3.5 & 3.0 & 2.5 & 2.0 & 1.5 & 1.0 & 0.5 & 0.0 & -0\end{array}$

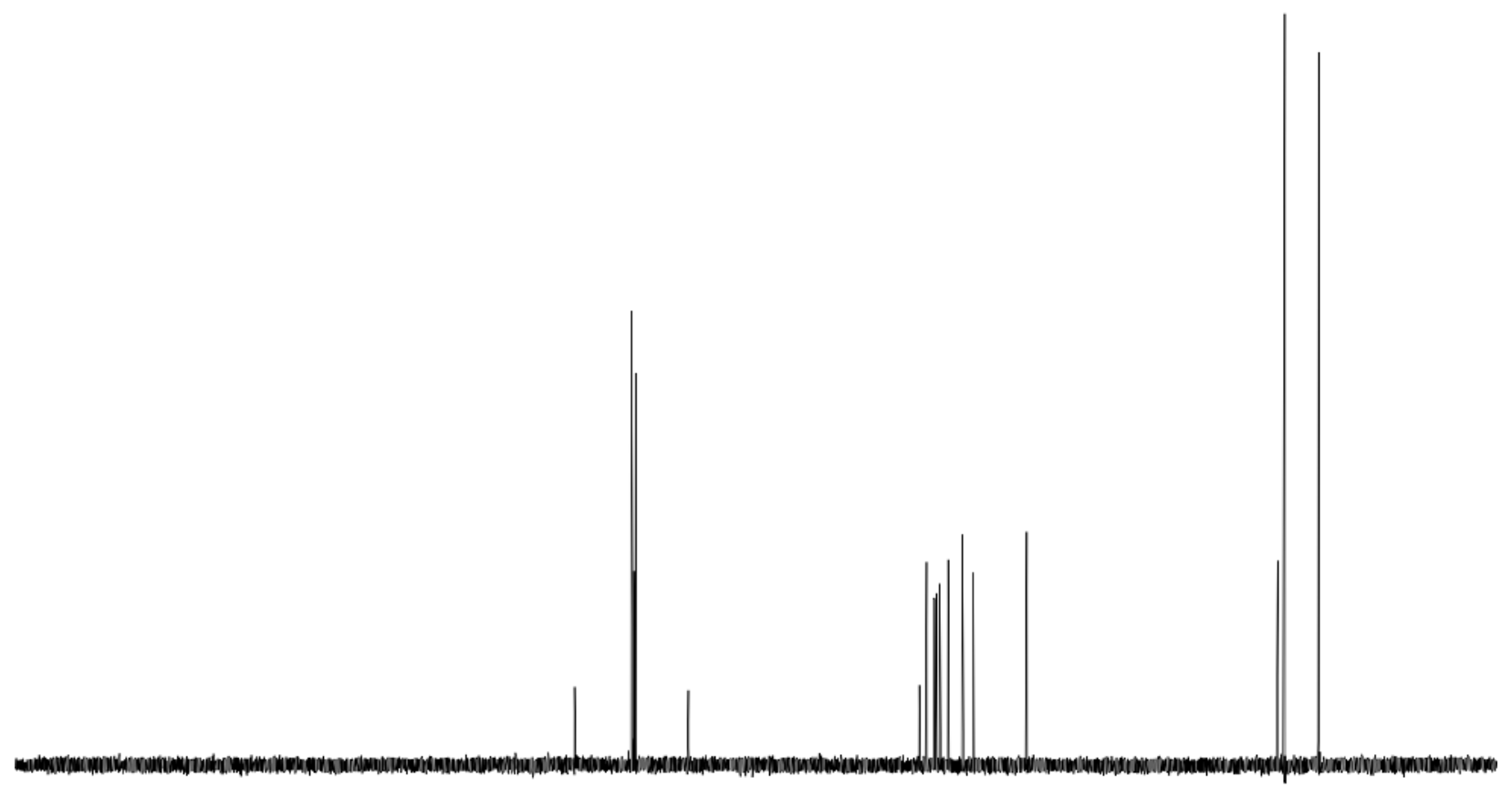

$\begin{array}{lllllllllllllllllllllllll}230 & 220 & 210 & 200 & 190 & 180 & 170 & 160 & 150 & 140 & 130 & 120 & 110 & 100 & 90 & 80 & 70 & 60 & 50 & 40 & 30 & 20 & 10 & 0 & -10\end{array}$ 


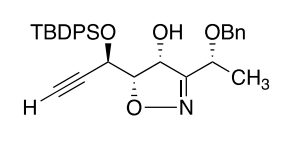

23
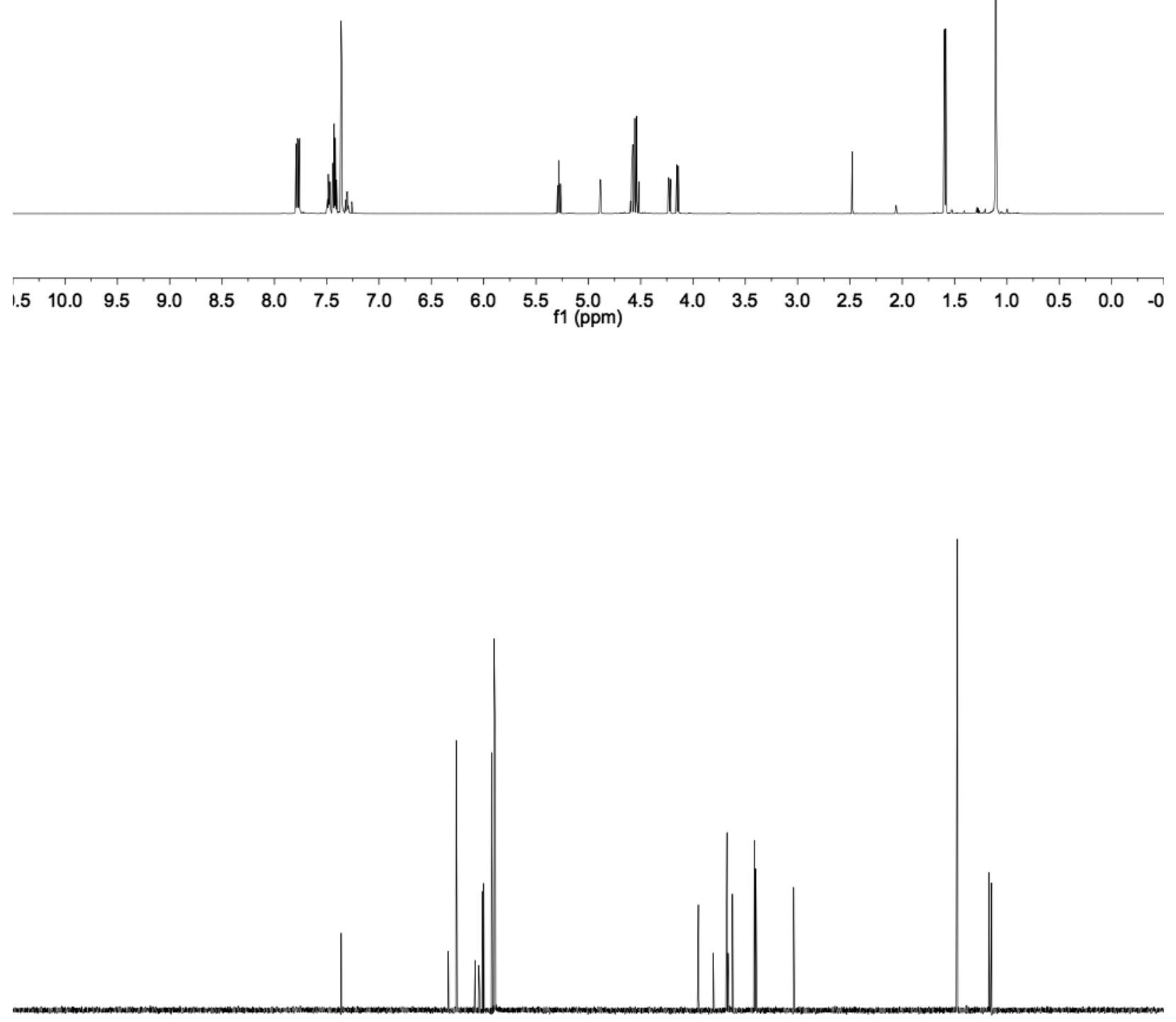

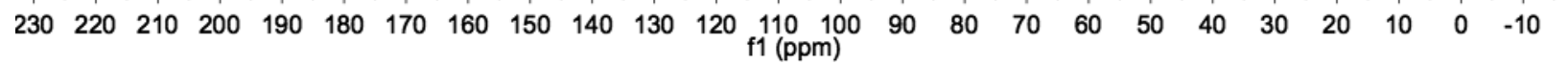




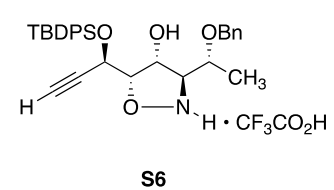

s6
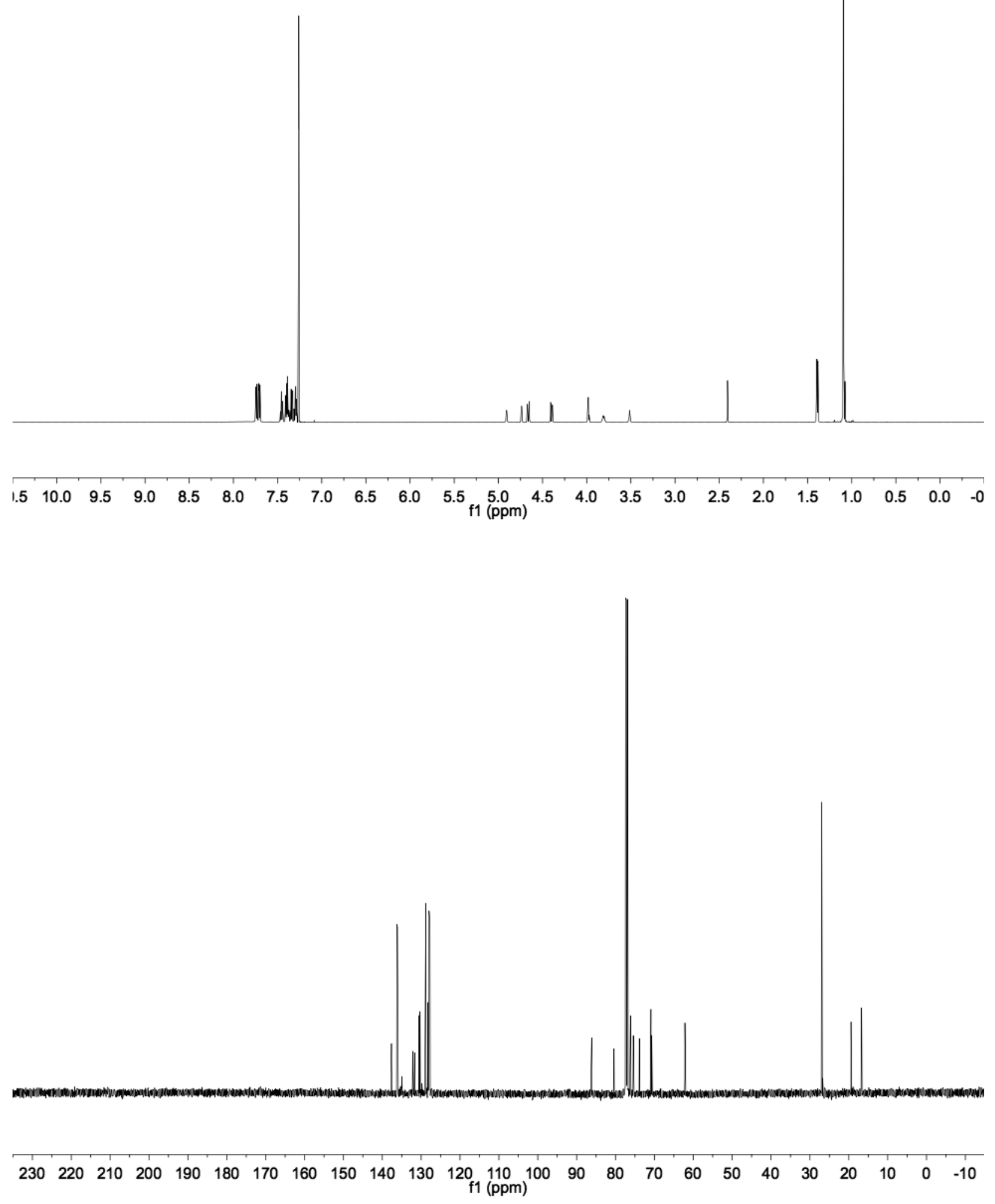


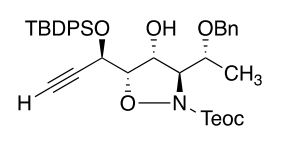

24
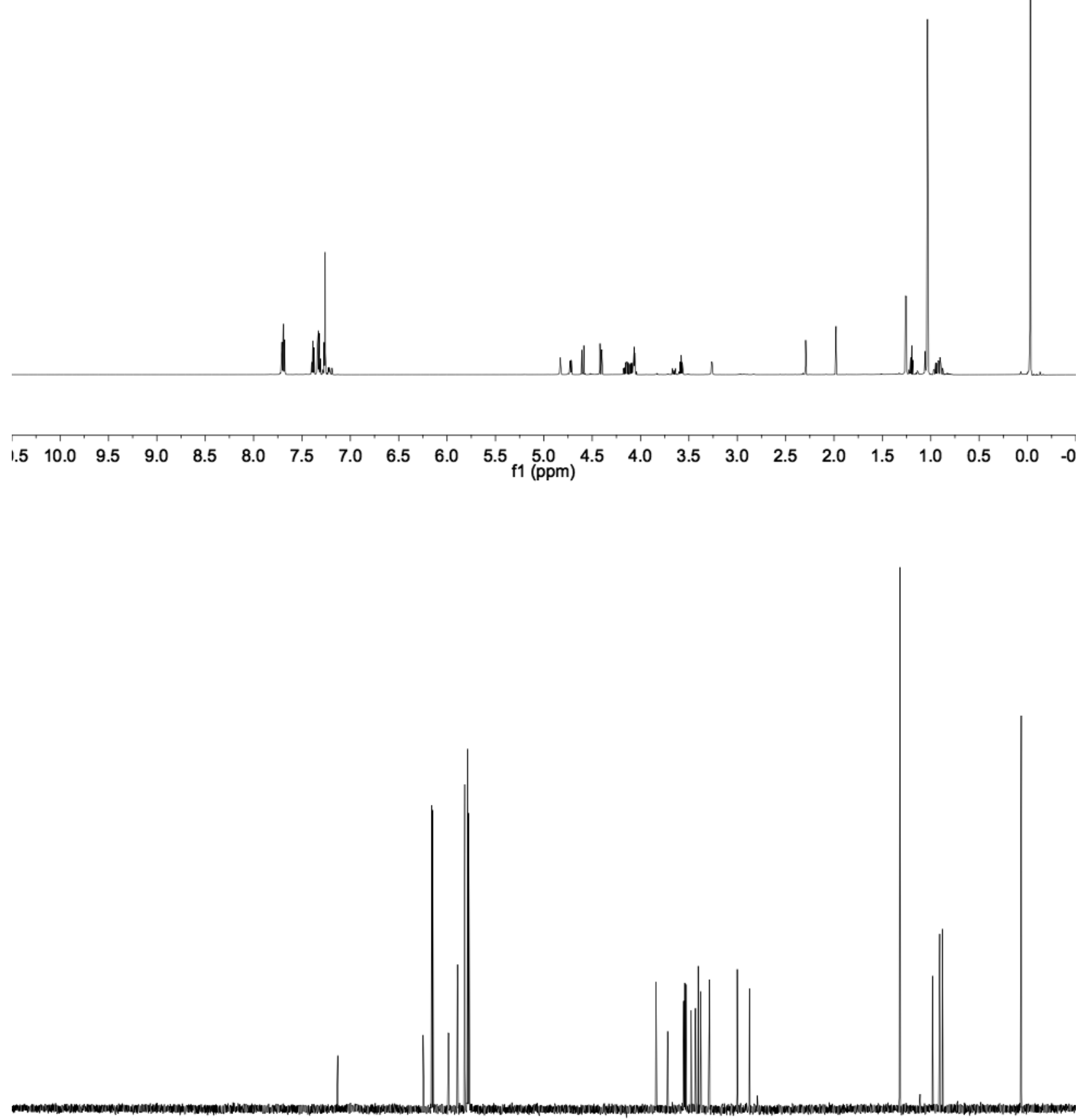

$\begin{array}{llllllllllllllllllllllllll}230 & 220 & 210 & 200 & 190 & 180 & 170 & 160 & 150 & 140 & 130 & 120 & 110 & 100 & 90 & 80 & 70 & 60 & 50 & 40 & 30 & 20 & 10 & 0 & -10\end{array}$ 

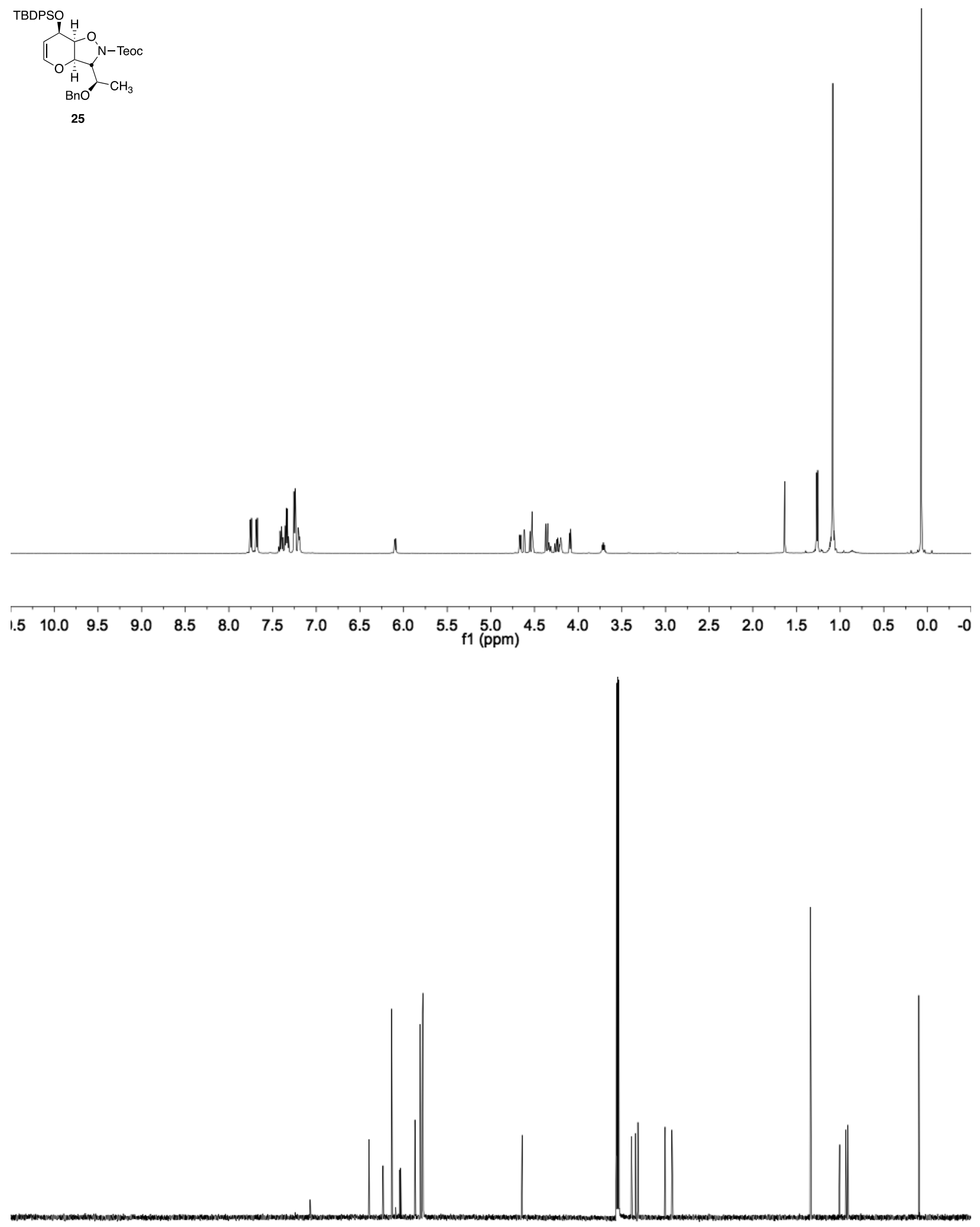

$\begin{array}{lllllllllllllllllllllllllllll}230 & 220 & 210 & 200 & 190 & 180 & 170 & 160 & 150 & 140 & 130 & 120_{\mathrm{f} 1}(\mathrm{ppm}) & 100 & 90 & 80 & 70 & 60 & 50 & 40 & 30 & 20 & 10 & 0 & -10\end{array}$ 

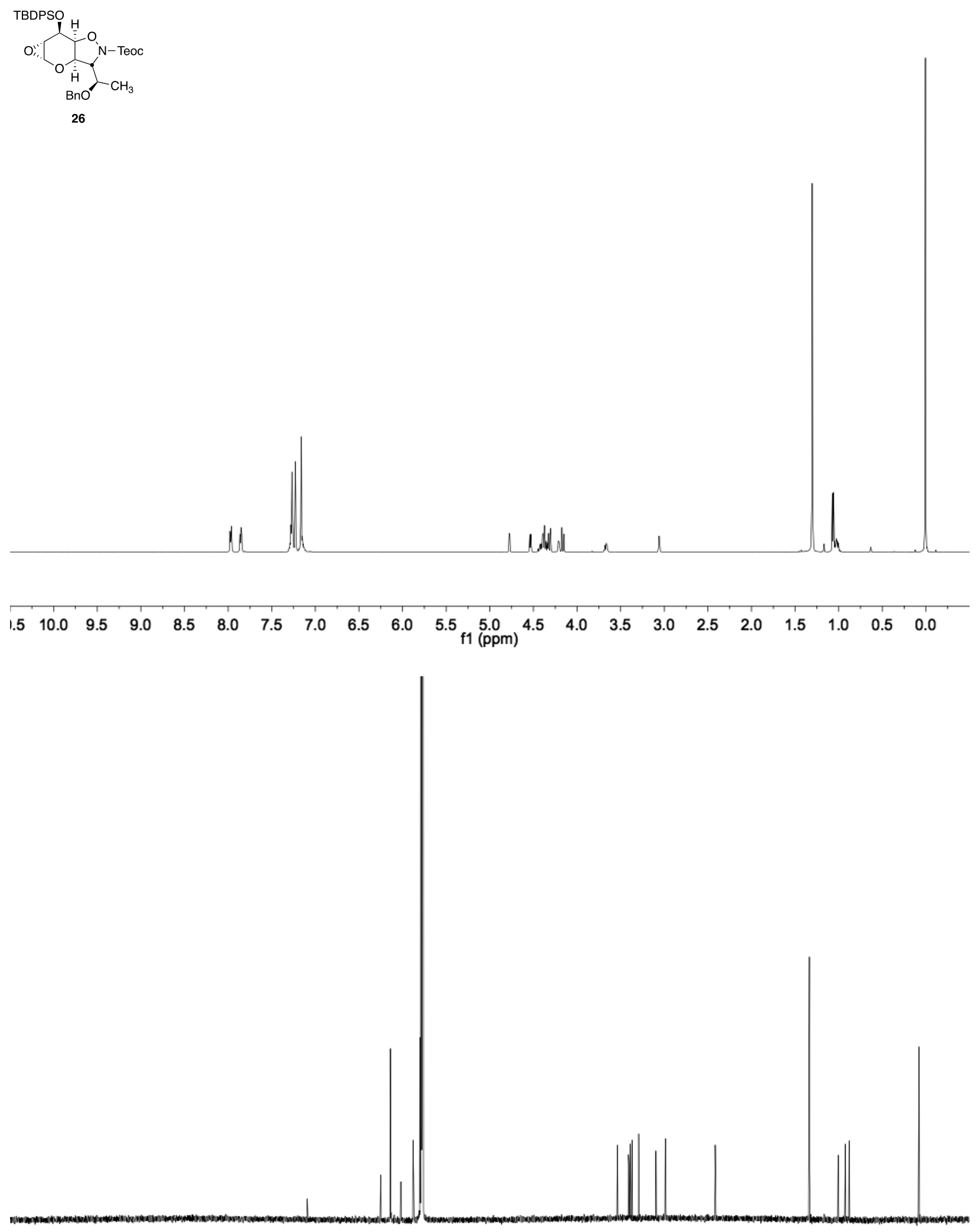

$\begin{array}{lllllllllllllllllllllllll}230 & 220 & 210 & 200 & 190 & 180 & 170 & 160 & 150 & 140 & 130 & 120 & 110 & 100 & 90 & 80 & 70 & 60 & 50 & 40 & 30 & 20 & 10 & 0 & -10\end{array}$ 

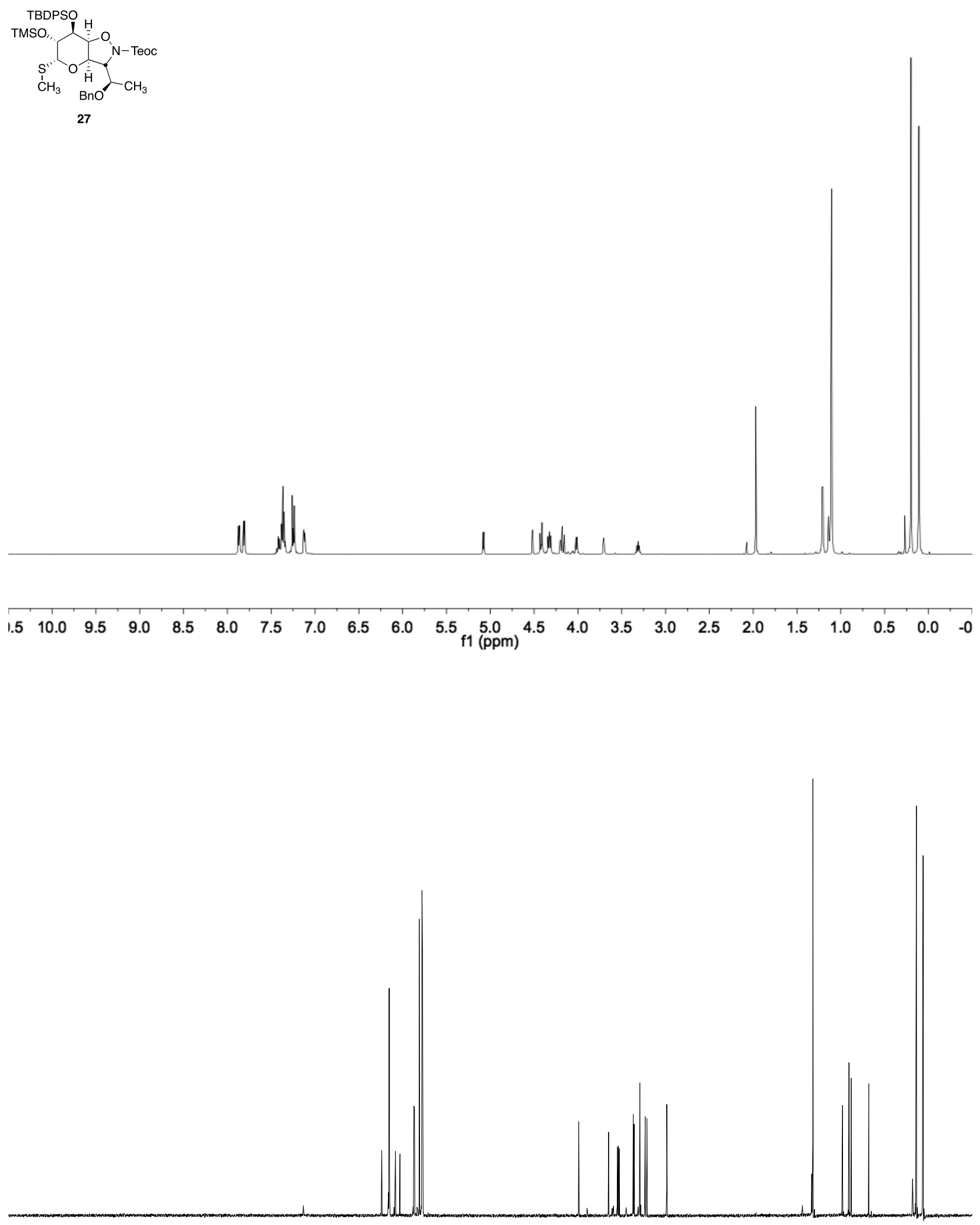

$\begin{array}{lllllllllllllllllllllllll}230 & 220 & 210 & 200 & 190 & 180 & 170 & 160 & 150 & 140 & 130 & 120 & 110 & 100 & 90 & 80 & 70 & 60 & 50 & 40 & 30 & 20 & 10 & 0 & -10\end{array}$ 


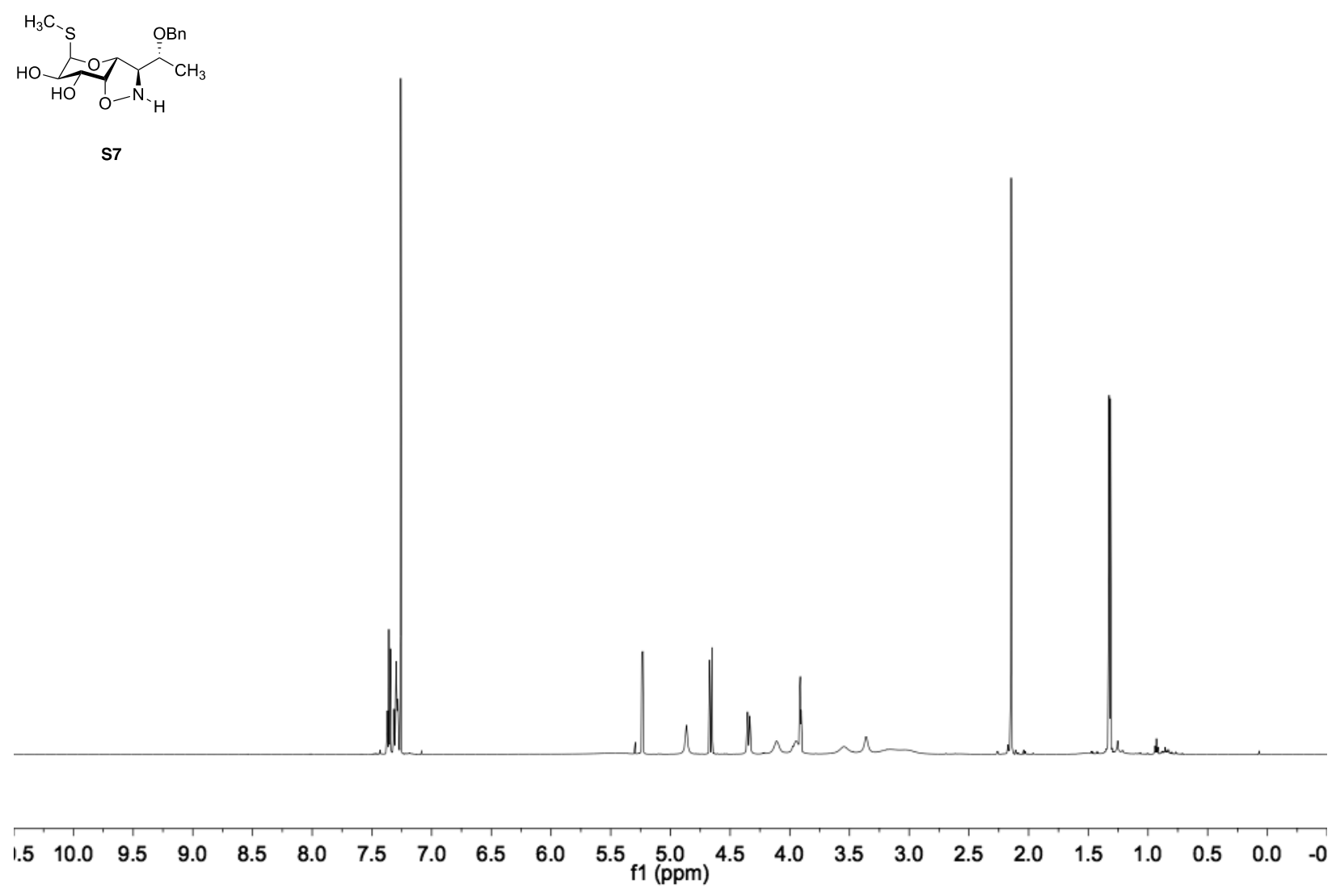




$$
\begin{aligned}
& \mathrm{H}_{3} \mathrm{C}_{\mathrm{S}} \quad \mathrm{OBn} \\
& \mathrm{HO} \underbrace{\mathrm{O}}_{\mathrm{O}-\mathrm{N}_{\mathrm{H}} \cdot \mathrm{CF}_{3} \mathrm{CO}_{2} \mathrm{H}} \\
& \text { s7 }
\end{aligned}
$$

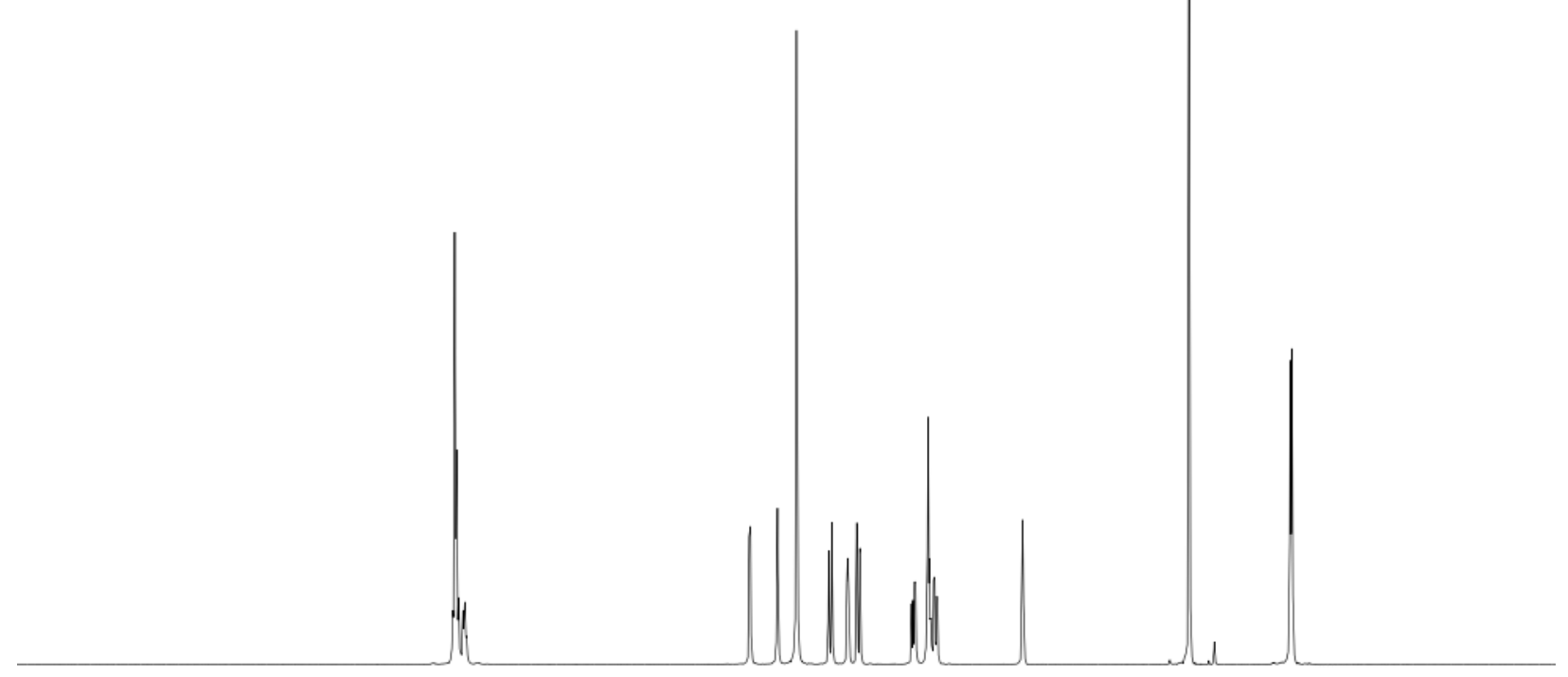

\begin{tabular}{lllllllllllllllllllllll}
\hline .5 & 10.0 & 9.5 & 9.0 & 8.5 & 8.0 & 7.5 & 7.0 & 6.5 & 6.0 & $5.5 \underset{\mathrm{f} 1}{\mathrm{f}} \mathbf{( \mathrm { ppm } )}$ & 4.5 & 4.0 & 3.5 & 3.0 & 2.5 & 2.0 & 1.5 & 1.0 & 0.5 & 0.0 & -0
\end{tabular}

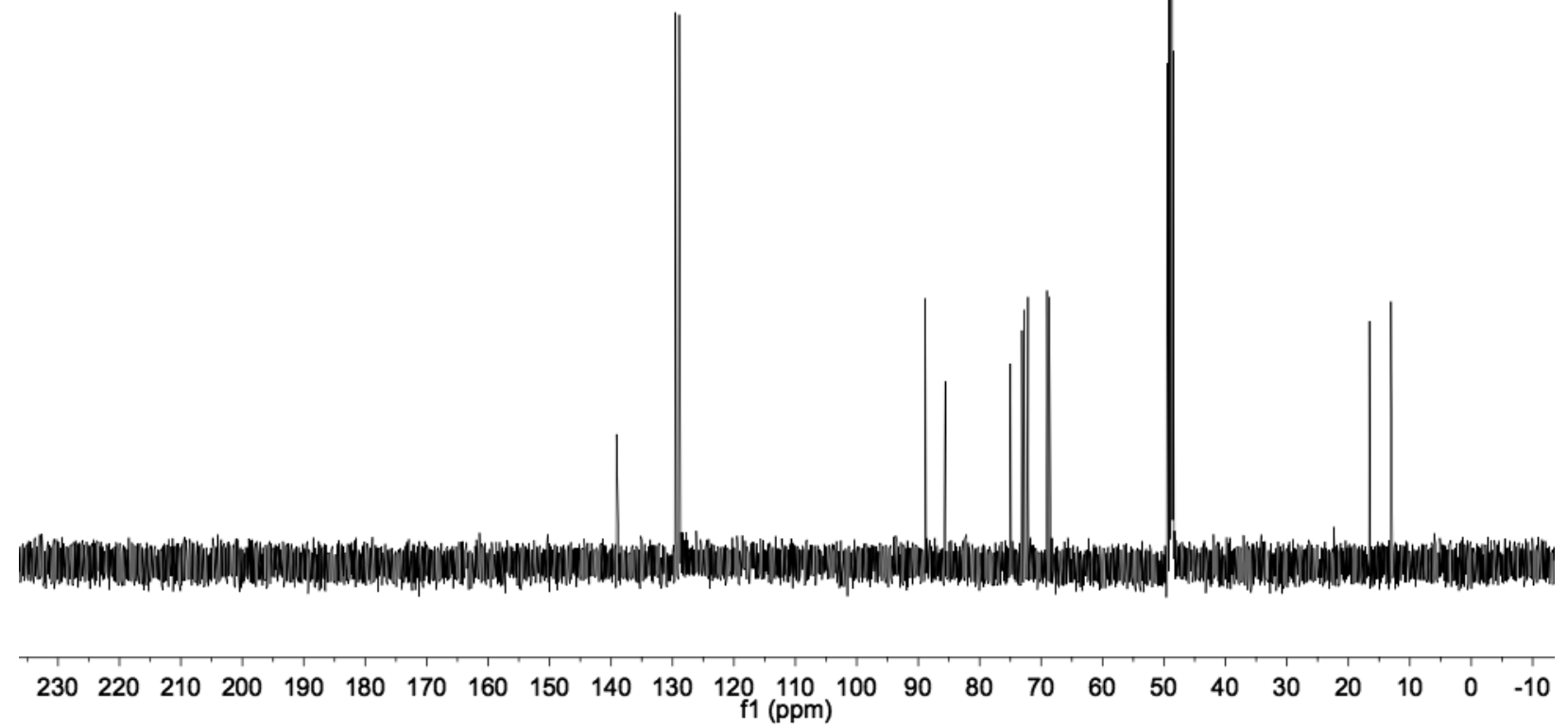



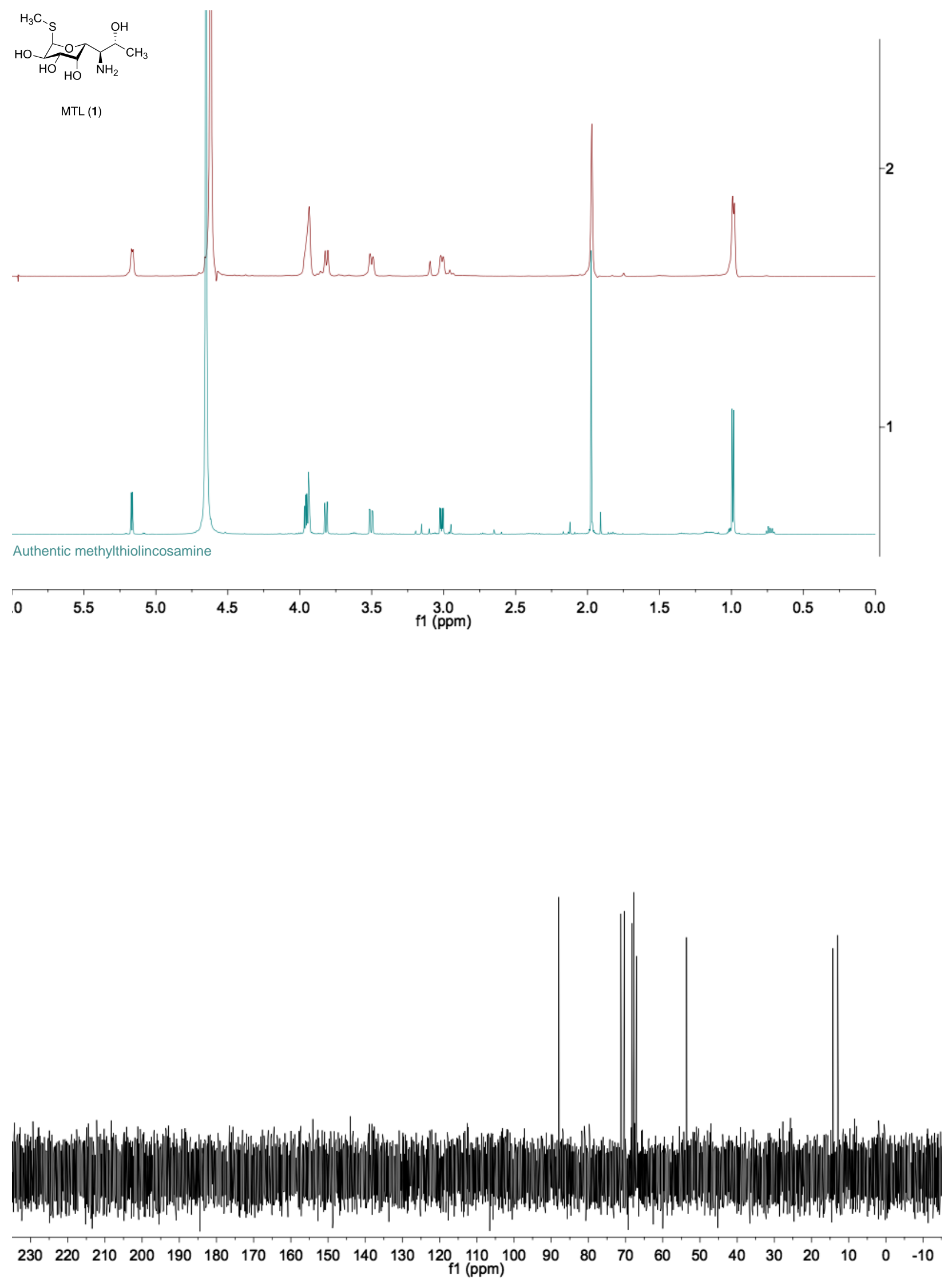


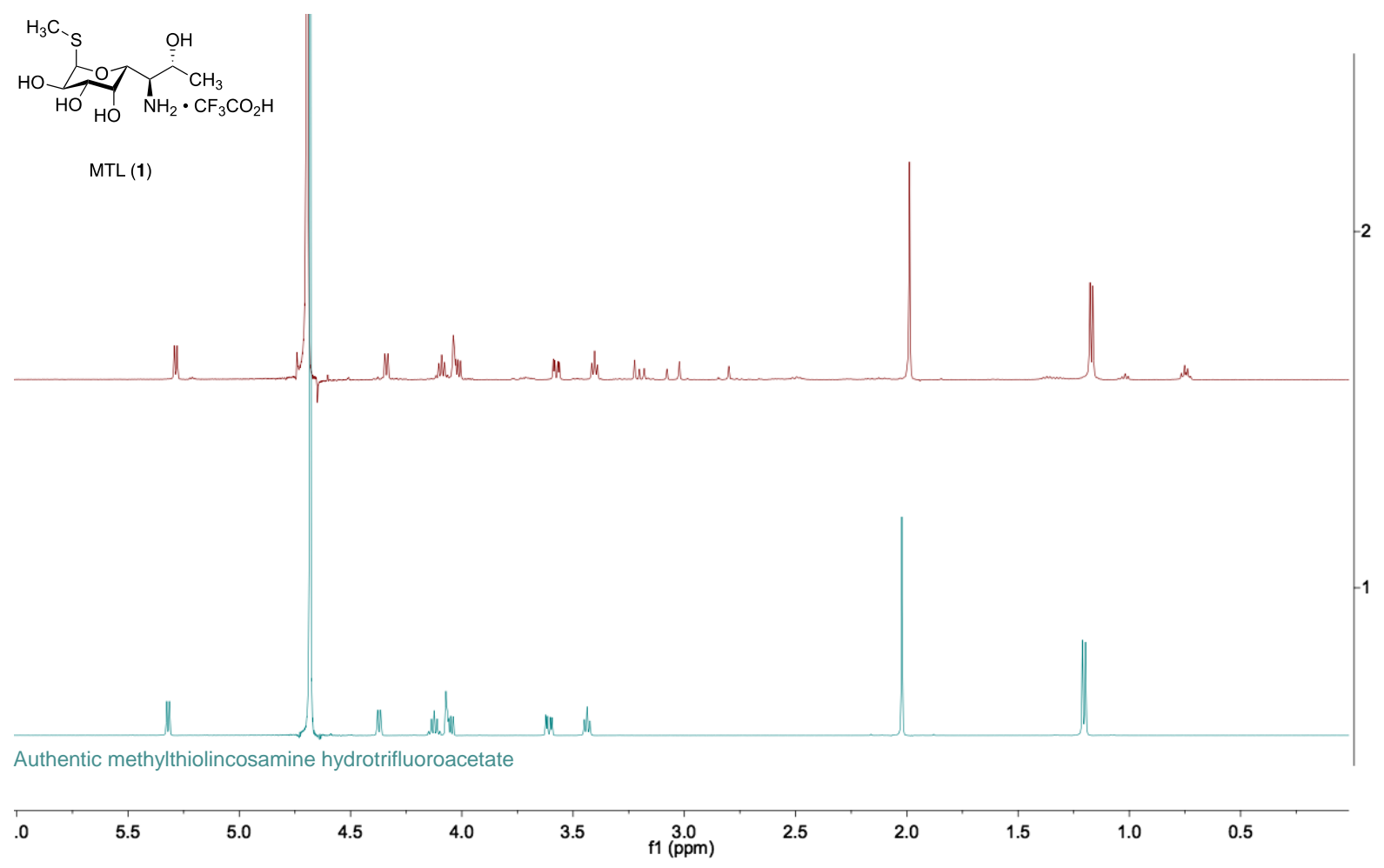



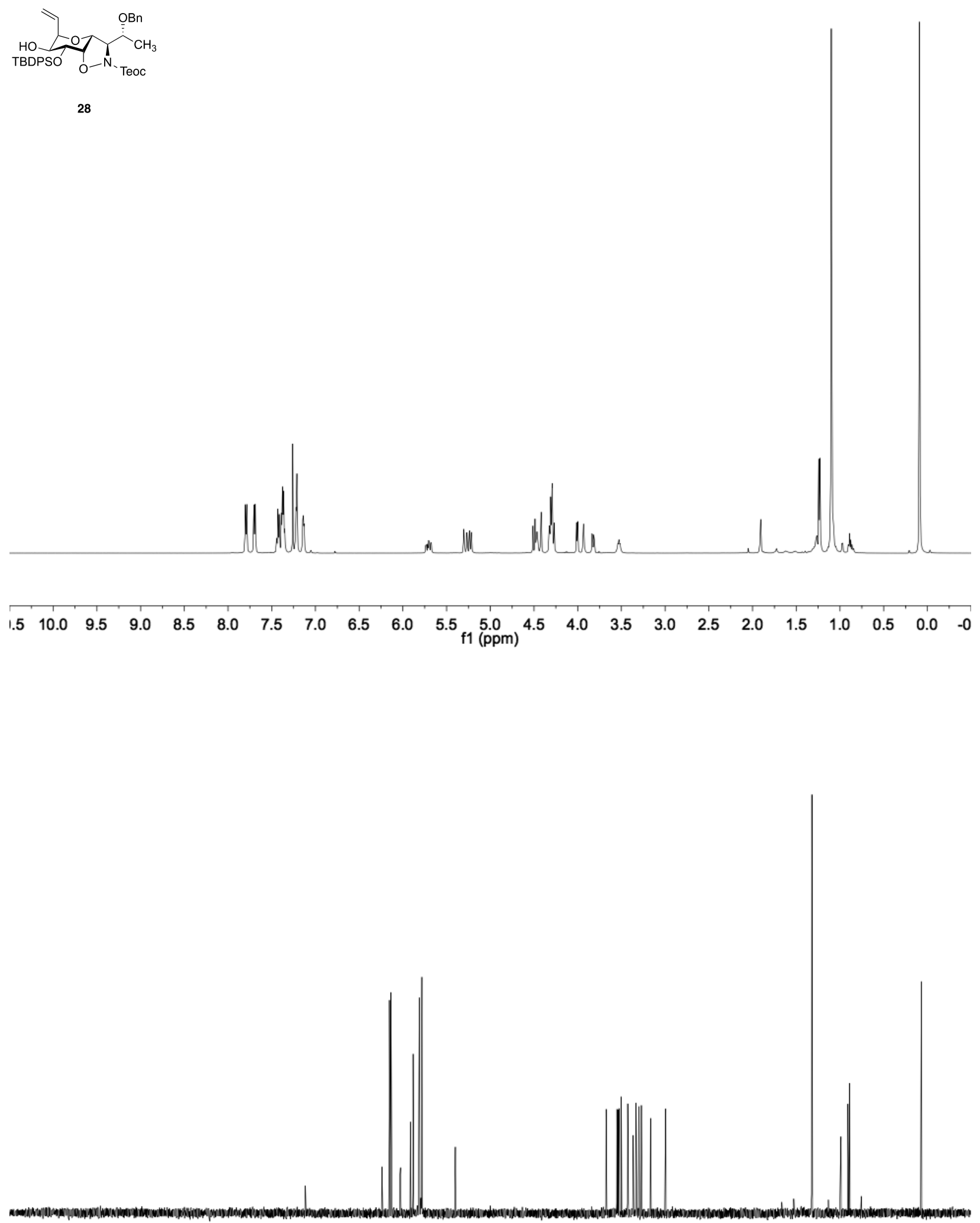

$\begin{array}{lllllllllllllllllllllllll}230 & 220 & 210 & 200 & 190 & 180 & 170 & 160 & 150 & 140 & 130 & 120_{\mathrm{f} 1}(\mathrm{ppm}) & 100 & 90 & 80 & 70 & 60 & 50 & 40 & 30 & 20 & 10 & 0 & -10\end{array}$ 


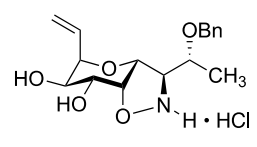

S8

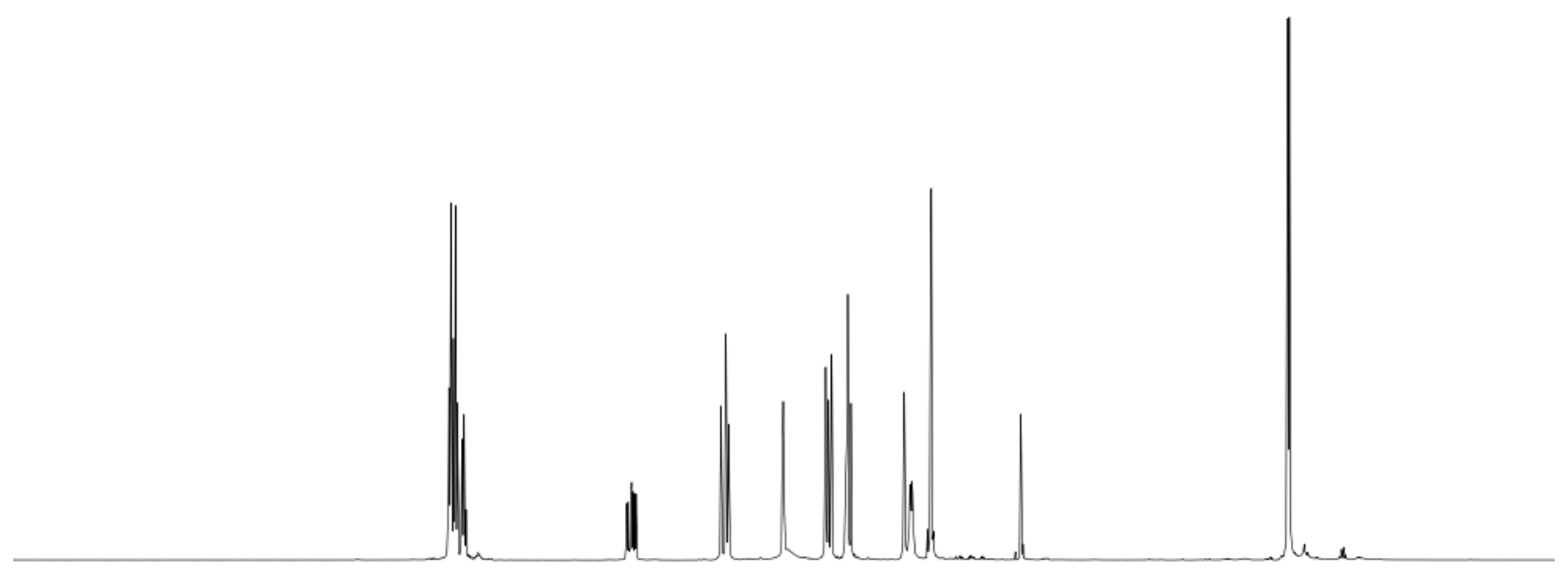

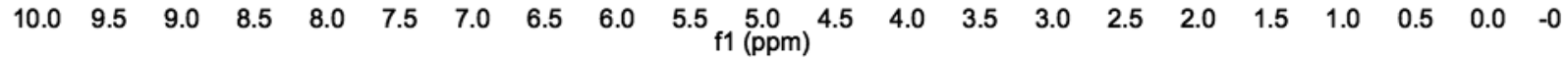

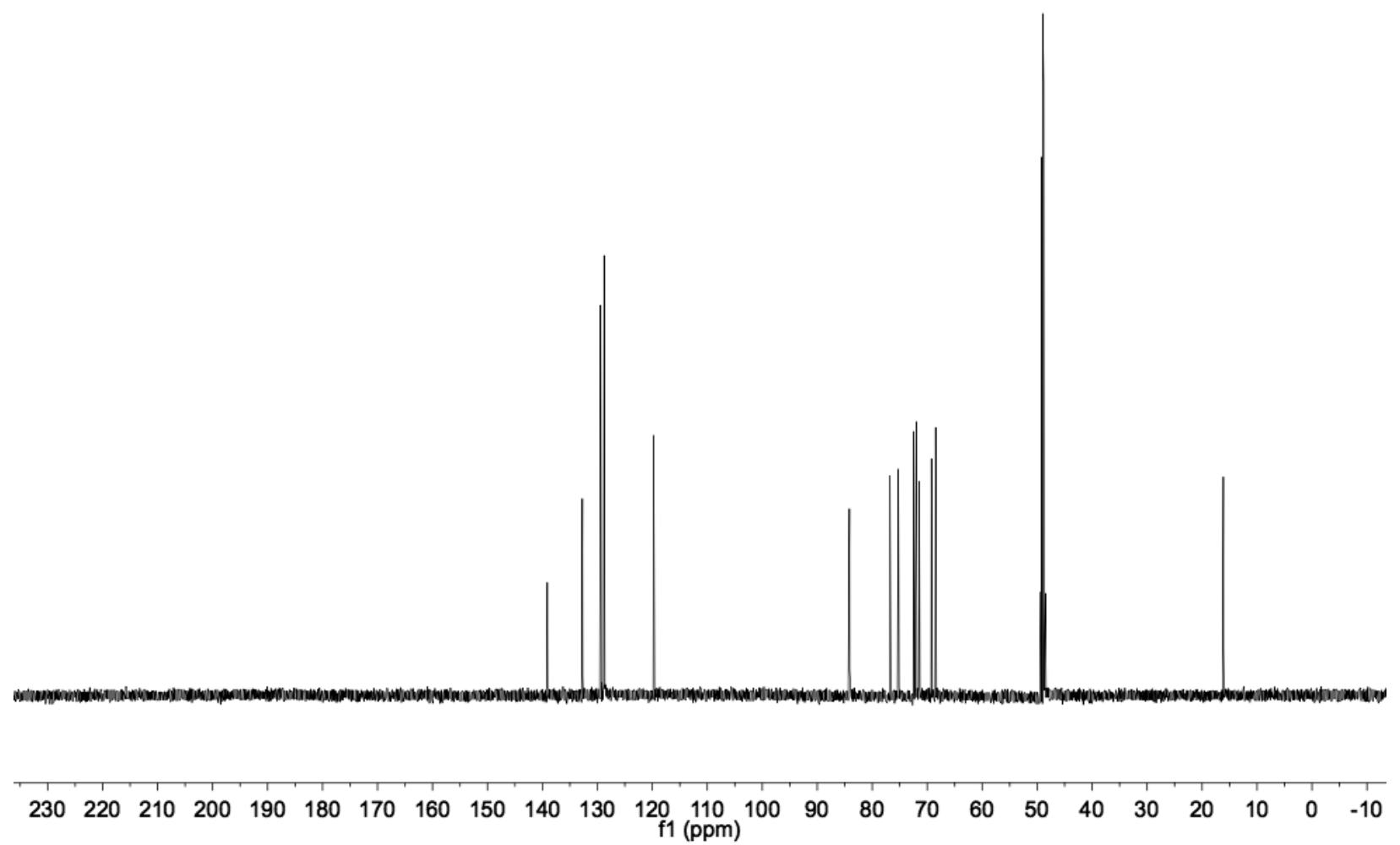


$\underbrace{\mathrm{OH}_{3} \mathrm{C}}_{\mathrm{HO}} \underbrace{\mathrm{CH}_{\mathrm{HCl}}}_{\mathrm{NH}_{2}} \mathrm{HCl}_{29}^{\mathrm{OH}}$

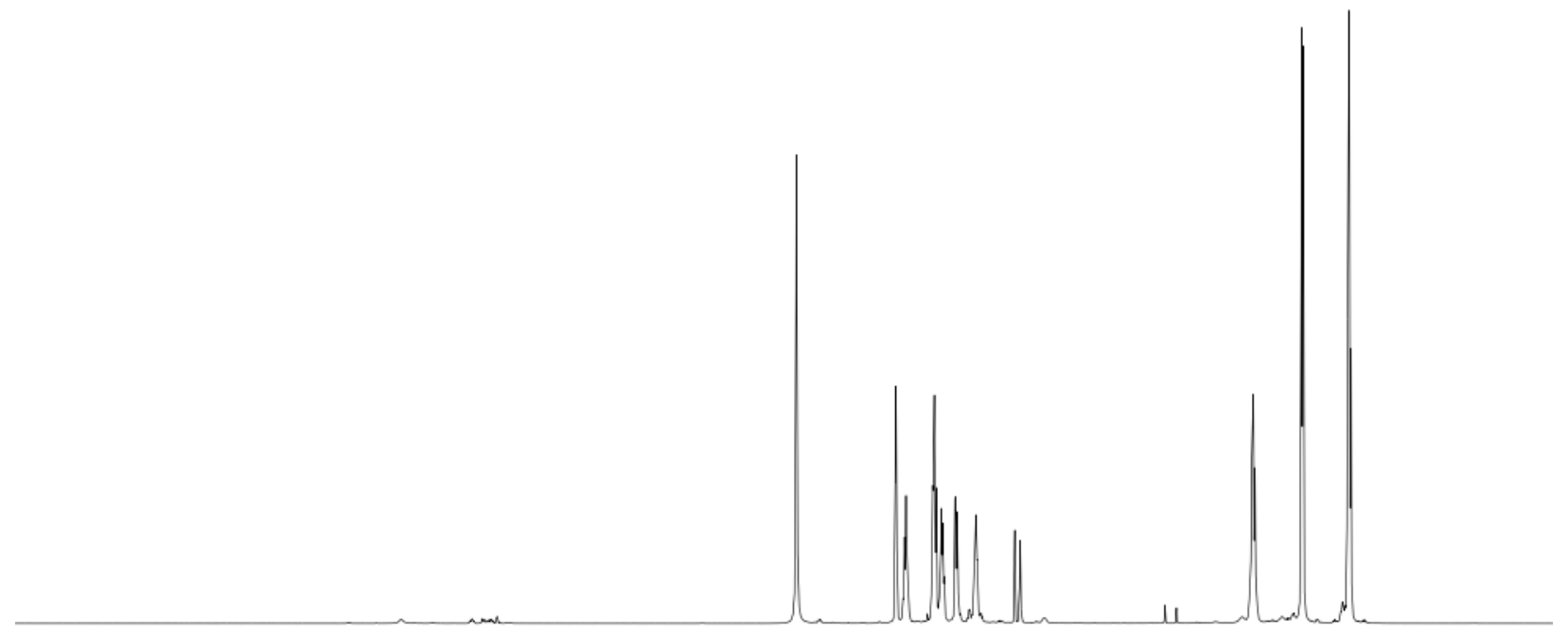

\begin{tabular}{lllllllllllllllllllllll}
\hline .5 & 10.0 & 9.5 & 9.0 & 8.5 & 8.0 & 7.5 & 7.0 & 6.5 & 6.0 & $5.5 \underset{\mathrm{f} 1}{\mathrm{f}} \mathbf{( \mathrm { ppm } )}$ & 4.5 & 4.0 & 3.5 & 3.0 & 2.5 & 2.0 & 1.5 & 1.0 & 0.5 & 0.0 & -0
\end{tabular}

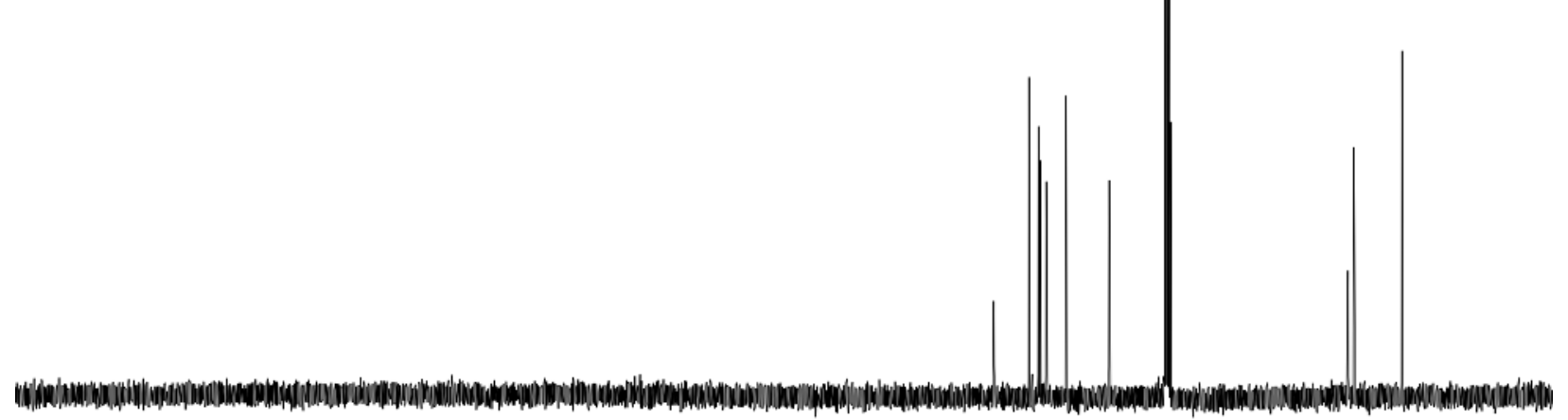

$\begin{array}{lllllllllllllllllllllllll}230 & 220 & 210 & 200 & 190 & 180 & 170 & 160 & 150 & 140 & 130 & 120 & 110 & 100 & 90 & 80 & 70 & 60 & 50 & 40 & 30 & 20 & 10 & 0 & -10\end{array}$ 

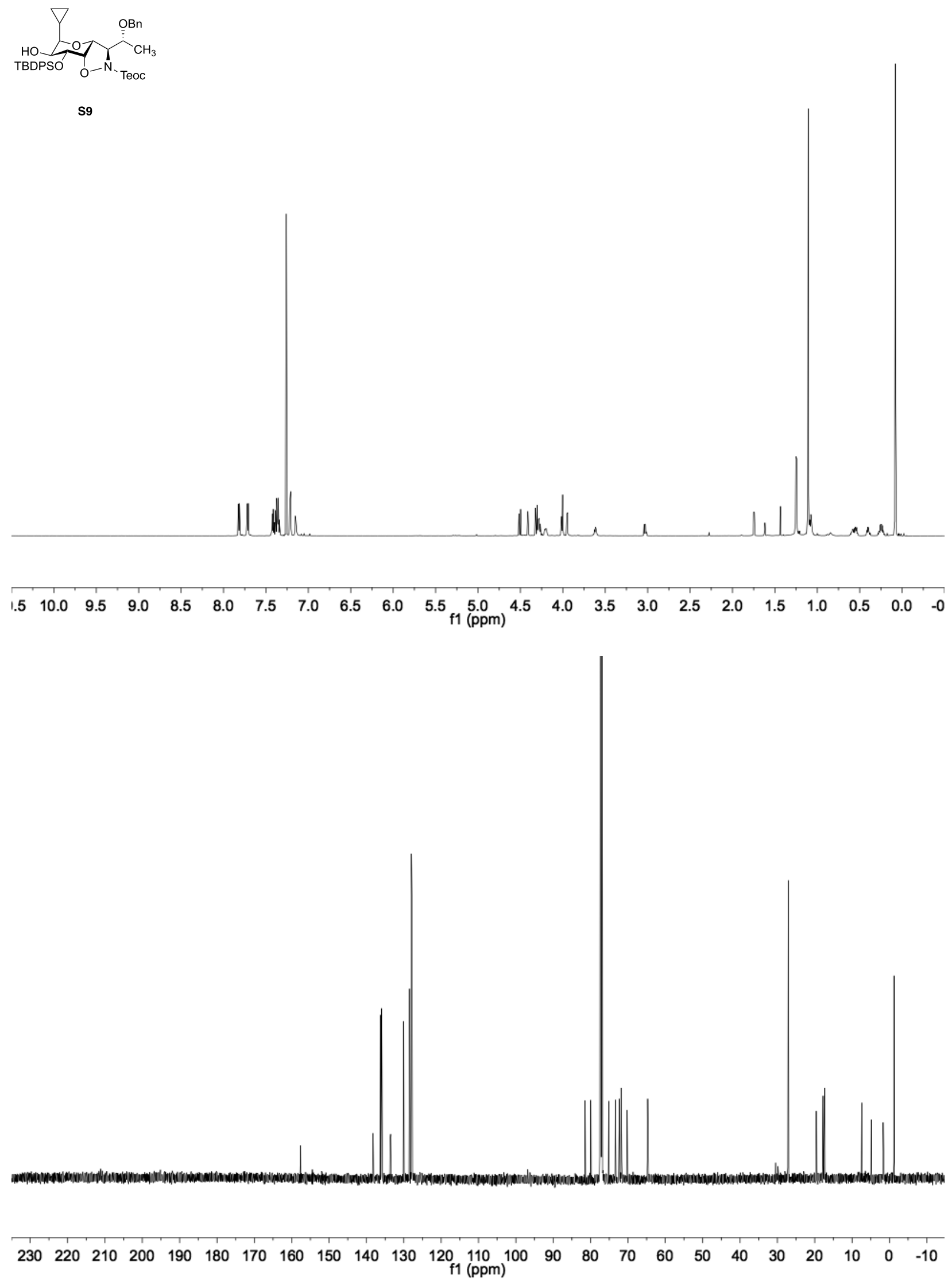
$\underbrace{}_{\mathrm{HO}}$

S10
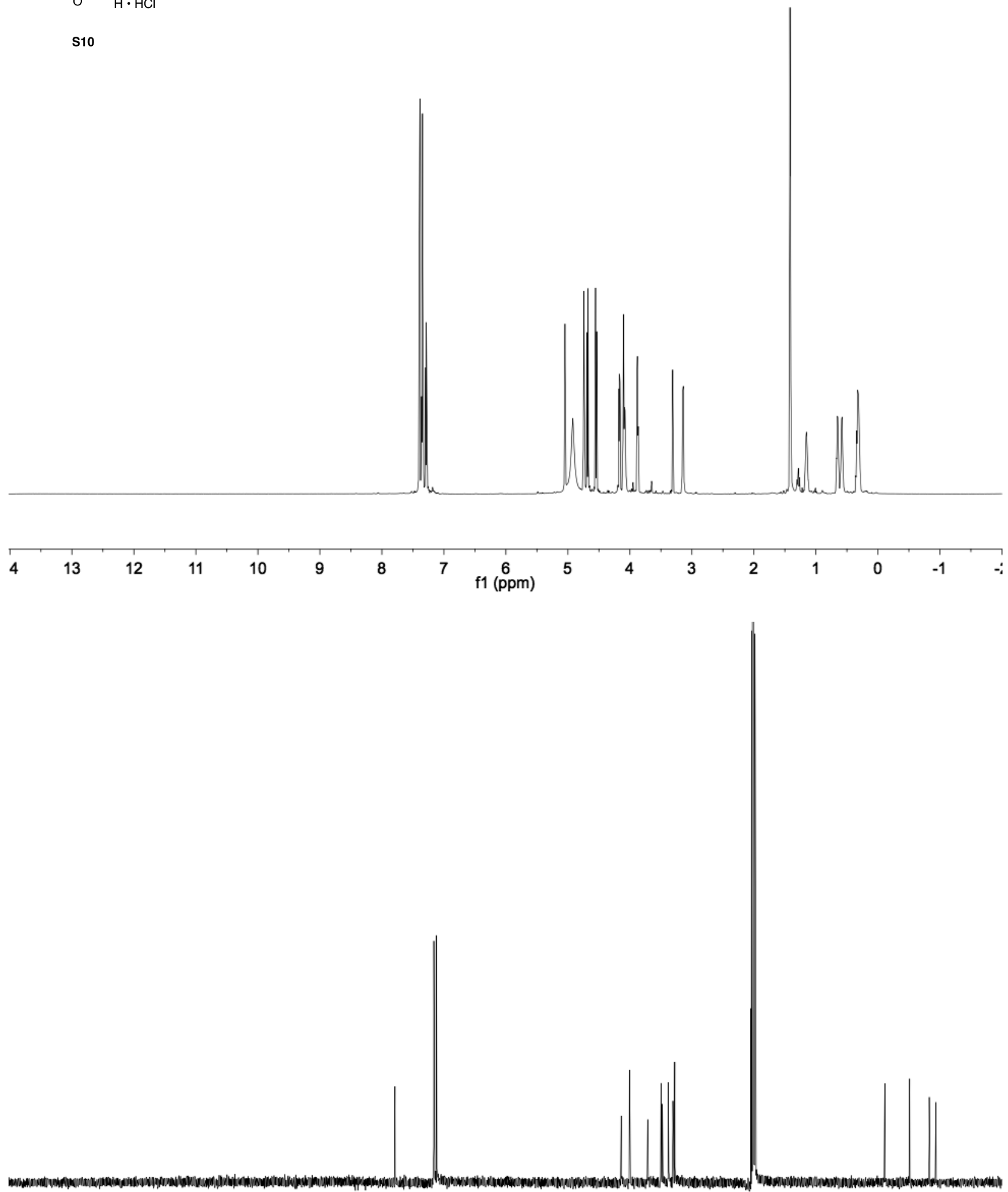

$\begin{array}{lllllllllllllllllllllllll}230 & 220 & 210 & 200 & 190 & 180 & 170 & 160 & 150 & 140 & 130 & 120 & 110 & 100 & 90 & 80 & 70 & 60 & 50 & 40 & 30 & 20 & 10 & 0 & -10\end{array}$ 


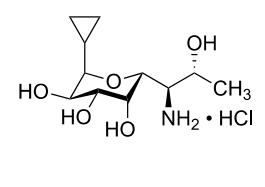

30

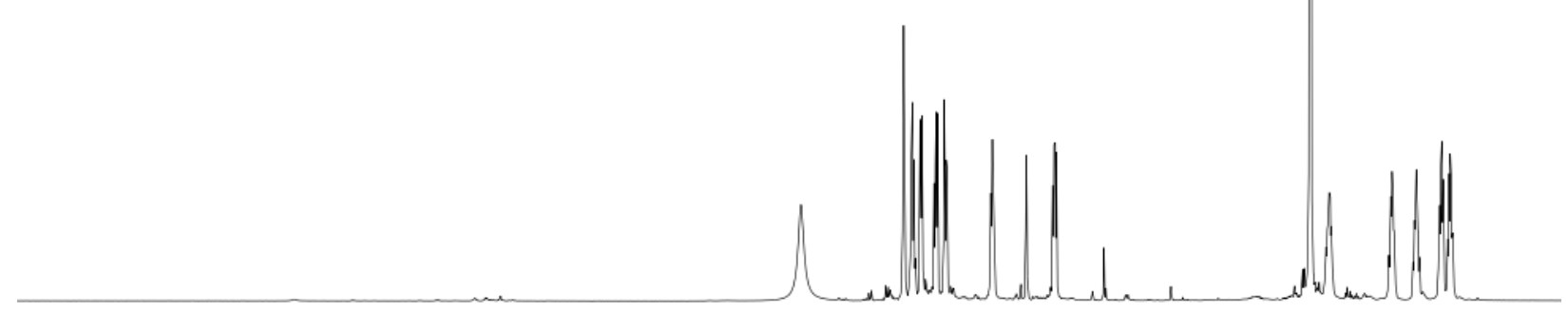

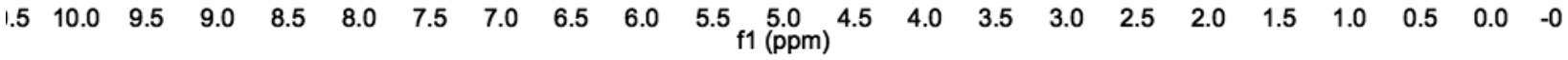

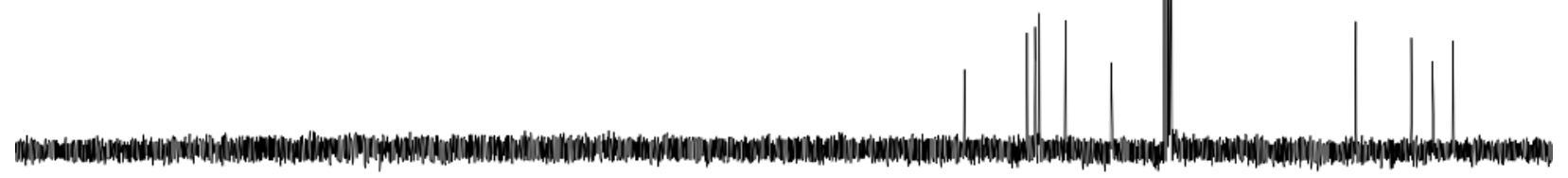

$\begin{array}{lllllllllllllllllllllllll}230 & 220 & 210 & 200 & 190 & 180 & 170 & 160 & 150 & 140 & 130 & 120 & 110 & 100 & 90 & 80 & 70 & 60 & 50 & 40 & 30 & 20 & 10 & 0 & -10\end{array}$ 

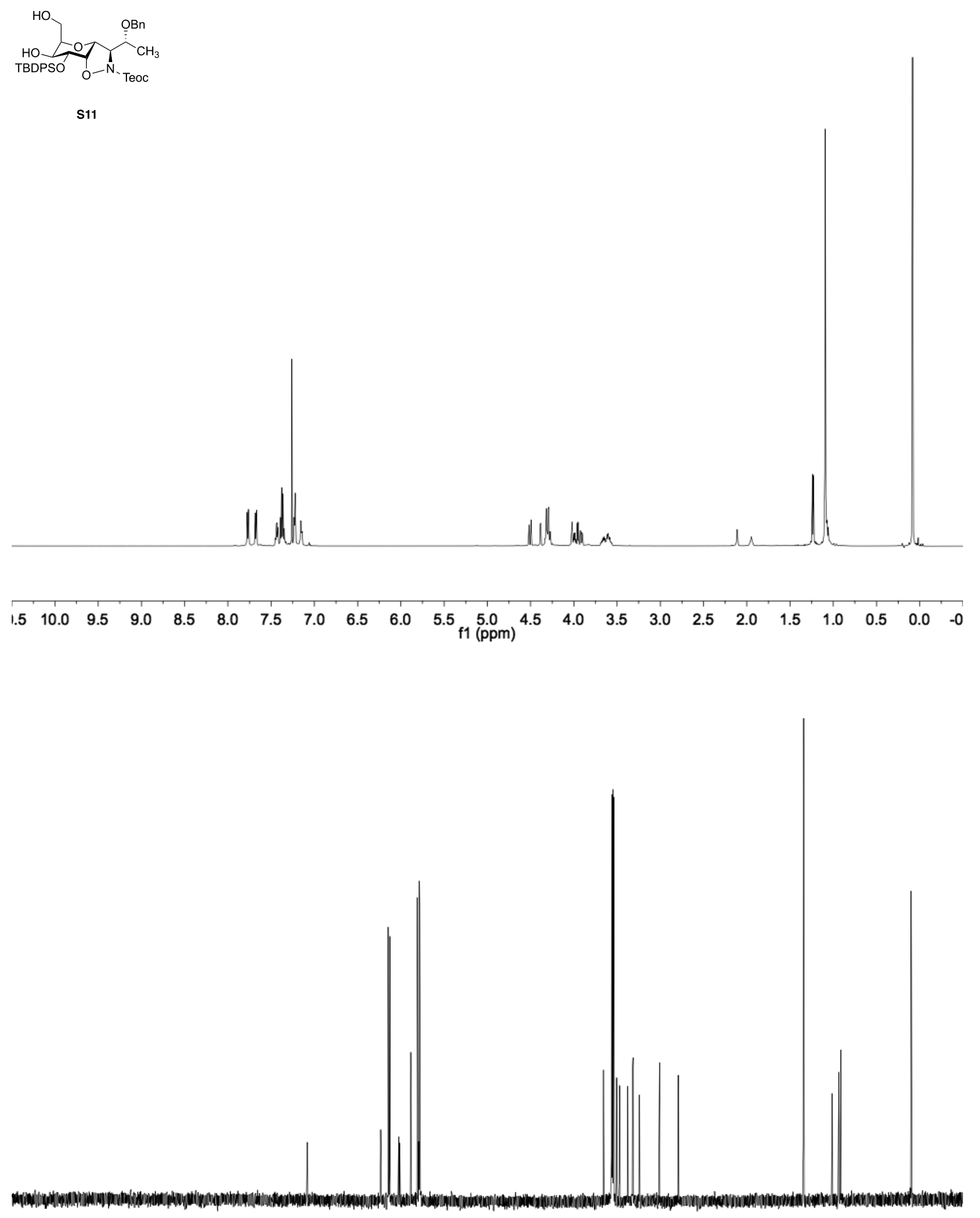

$\begin{array}{llllllllllllllllllllllllllll}230 & 220 & 210 & 200 & 190 & 180 & 170 & 160 & 150 & 140 & 130 & 120_{\mathrm{f} 1}(\mathrm{ppm}) & 100 & 90 & 80 & 70 & 60 & 50 & 40 & 30 & 20 & 10 & 0 & -10\end{array}$ 


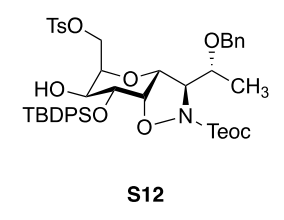

$\mathbf{S 1 2}$

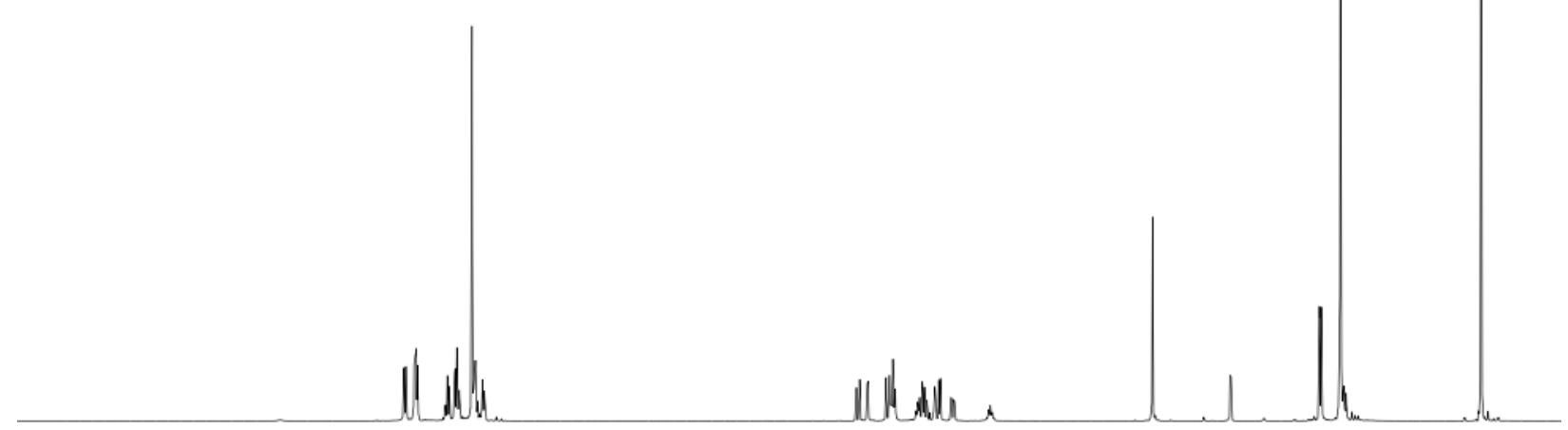

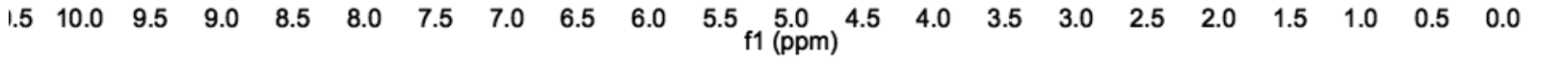

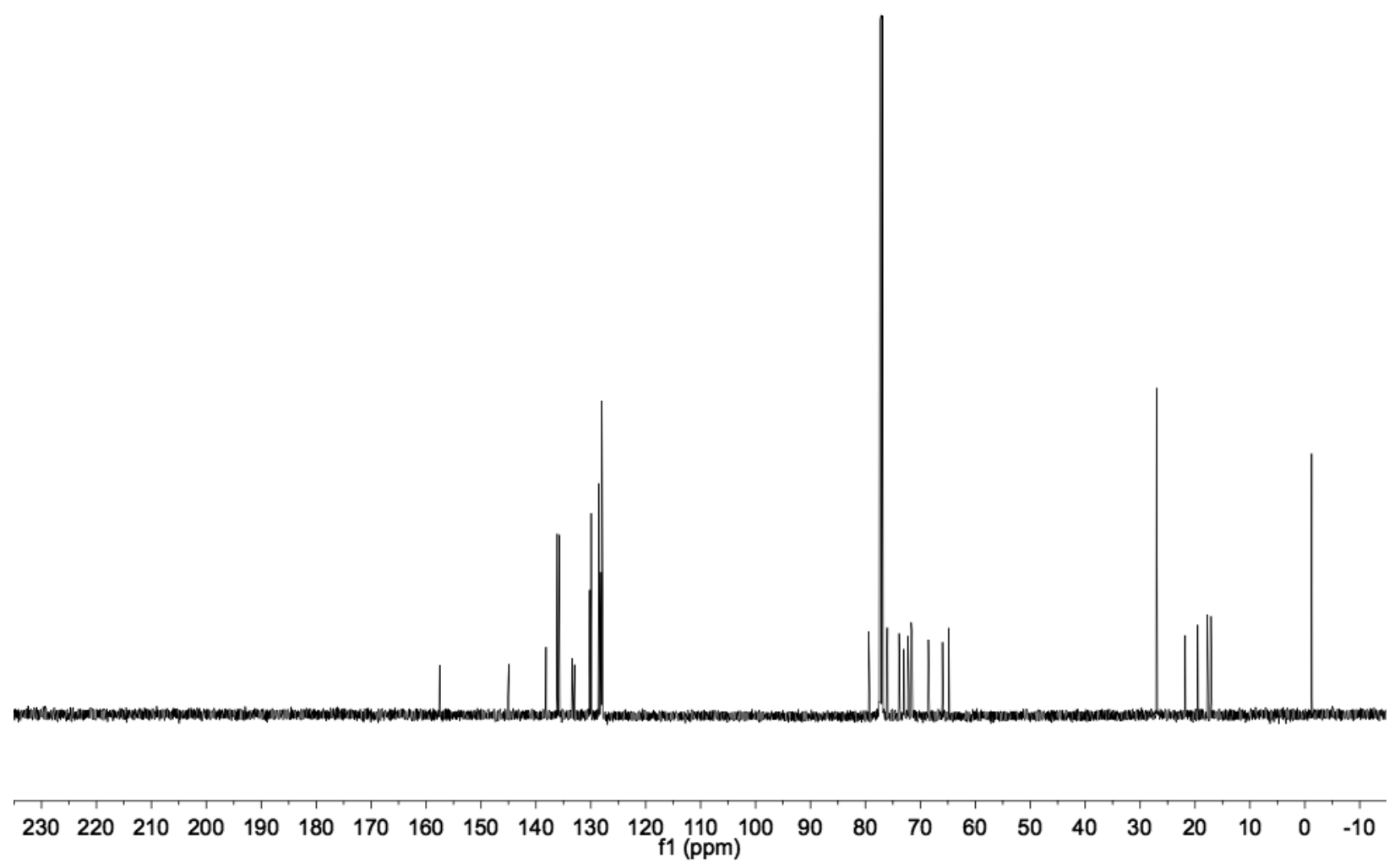



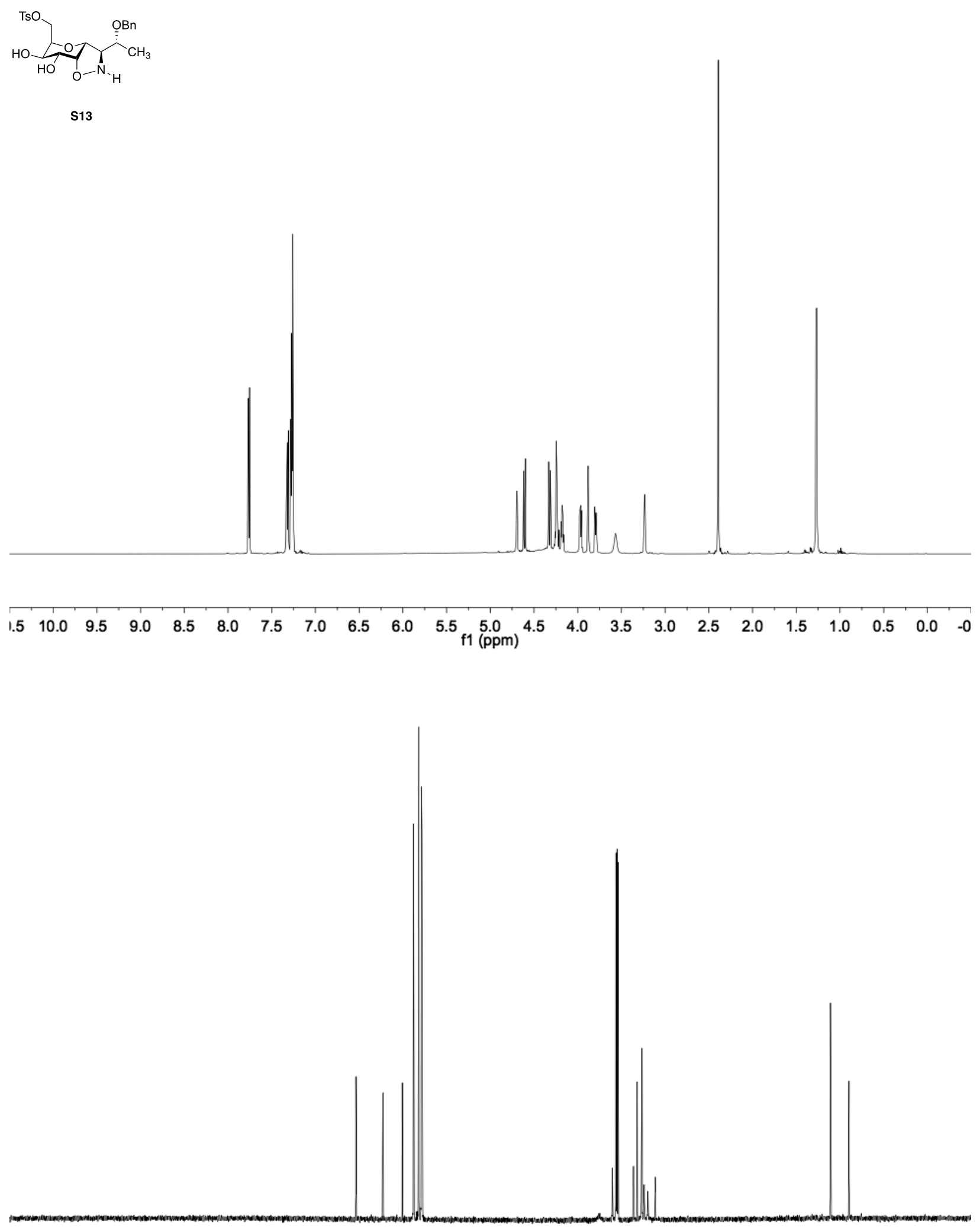

$\begin{array}{llllllllllllllllllllllllllll}230 & 220 & 210 & 200 & 190 & 180 & 170 & 160 & 150 & 140 & 130 & 120 & 110 & 100 & 90 & 80 & 70 & 60 & 50 & 40 & 30 & 20 & 10 & 0 & -10\end{array}$ 


$$
\underbrace{\mathrm{TsO}}_{\mathrm{HO}} \underbrace{\mathrm{OH}}_{\mathrm{HO}}
$$

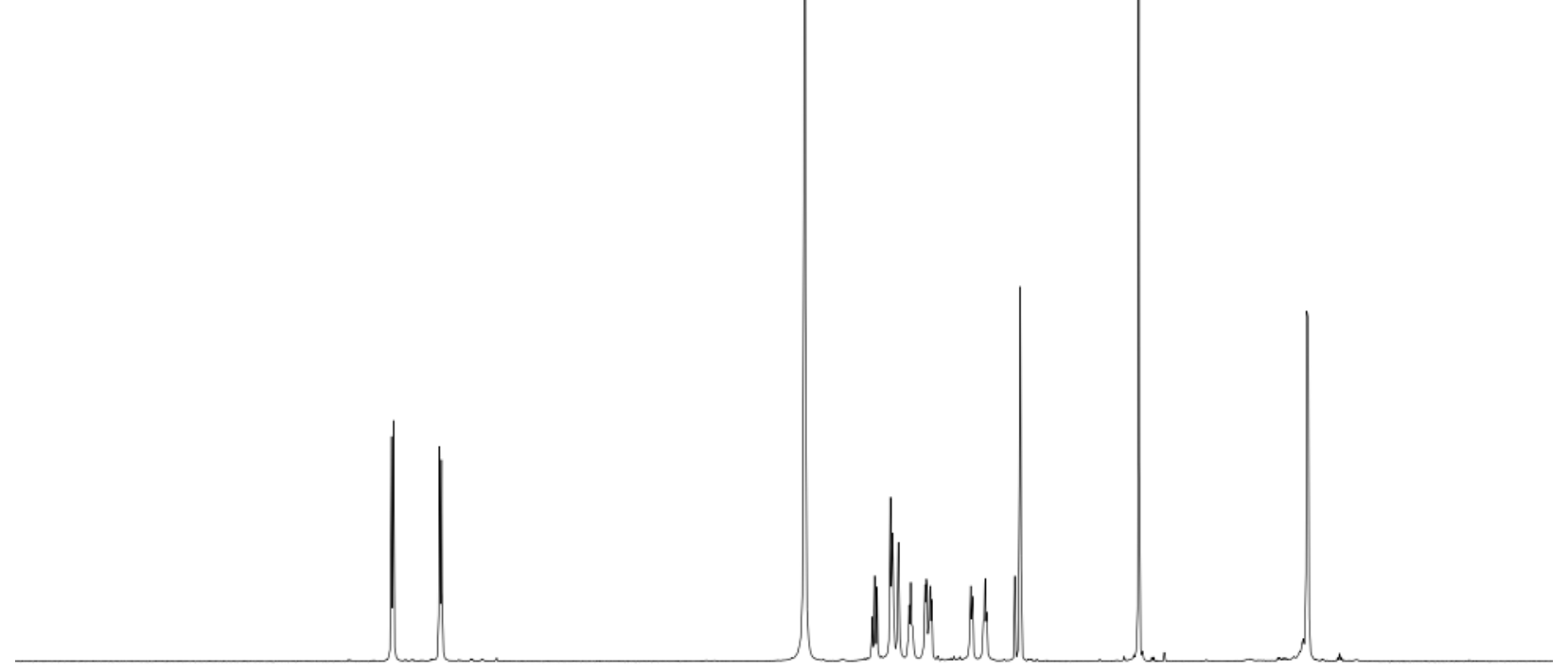

$\begin{array}{lllllllllllllllllllllll}. .5 & 10.0 & 9.5 & 9.0 & 8.5 & 8.0 & 7.5 & 7.0 & 6.5 & 6.0 & 5.5 \underset{\mathrm{f} 1}{\mathrm{f}} \mathbf{( \mathrm { ppm } )} & 4.5 & 4.0 & 3.5 & 3.0 & 2.5 & 2.0 & 1.5 & 1.0 & 0.5 & 0.0 & -0\end{array}$

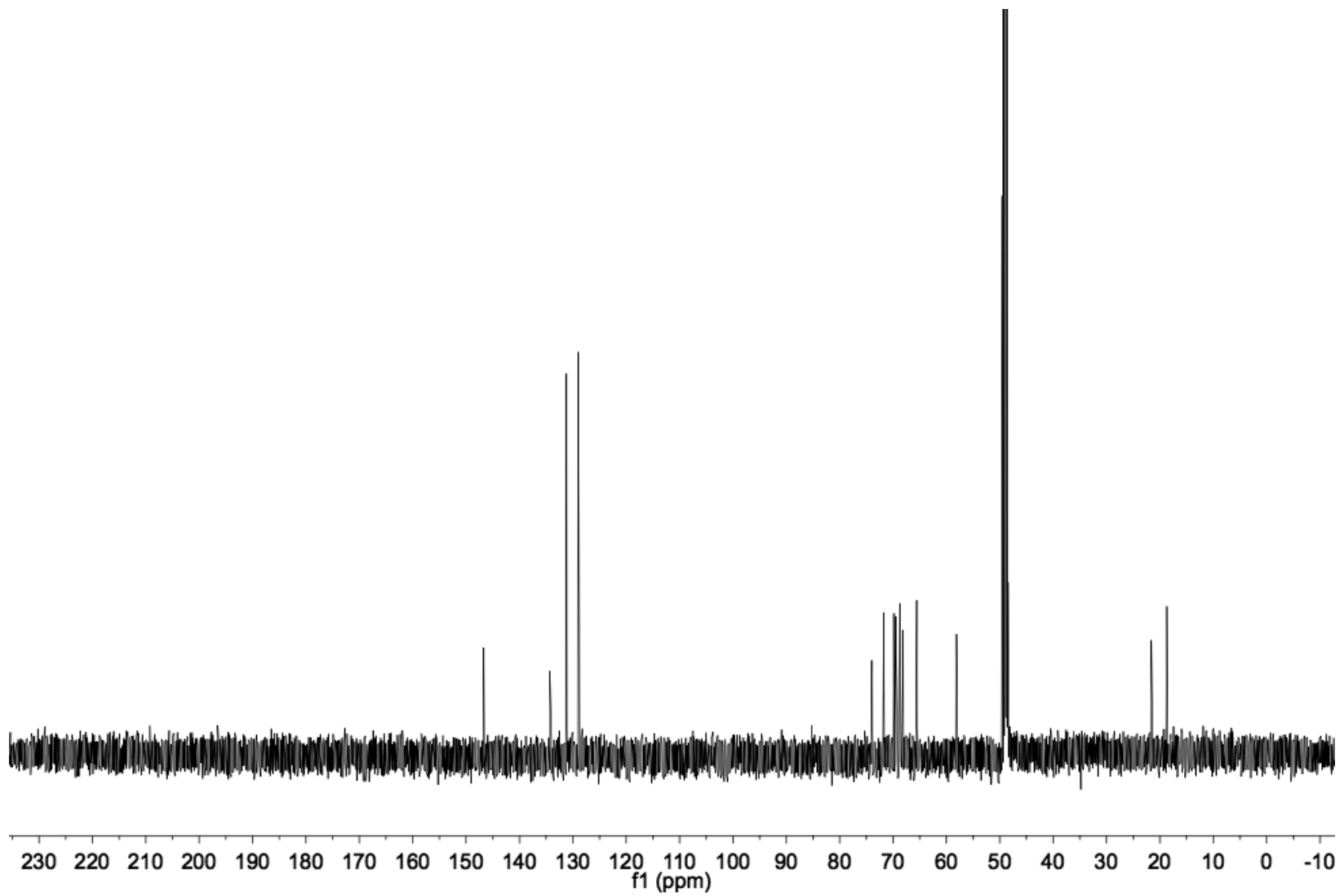




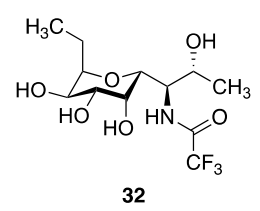

$\begin{array}{llllllllllllllllllllll}10.0 & 9.5 & 9.0 & 8.5 & 8.0 & 7.5 & 7.0 & 6.5 & 6.0 & 5.5 & \underset{\mathrm{f} 1}{(\mathrm{ppm})} & 4.0 & 4.0 & 3.5 & 3.0 & 2.5 & 2.0 & 1.5 & 1.0 & 0.5 & 0.0 & -0\end{array}$ 


$$
\text { S14 }
$$

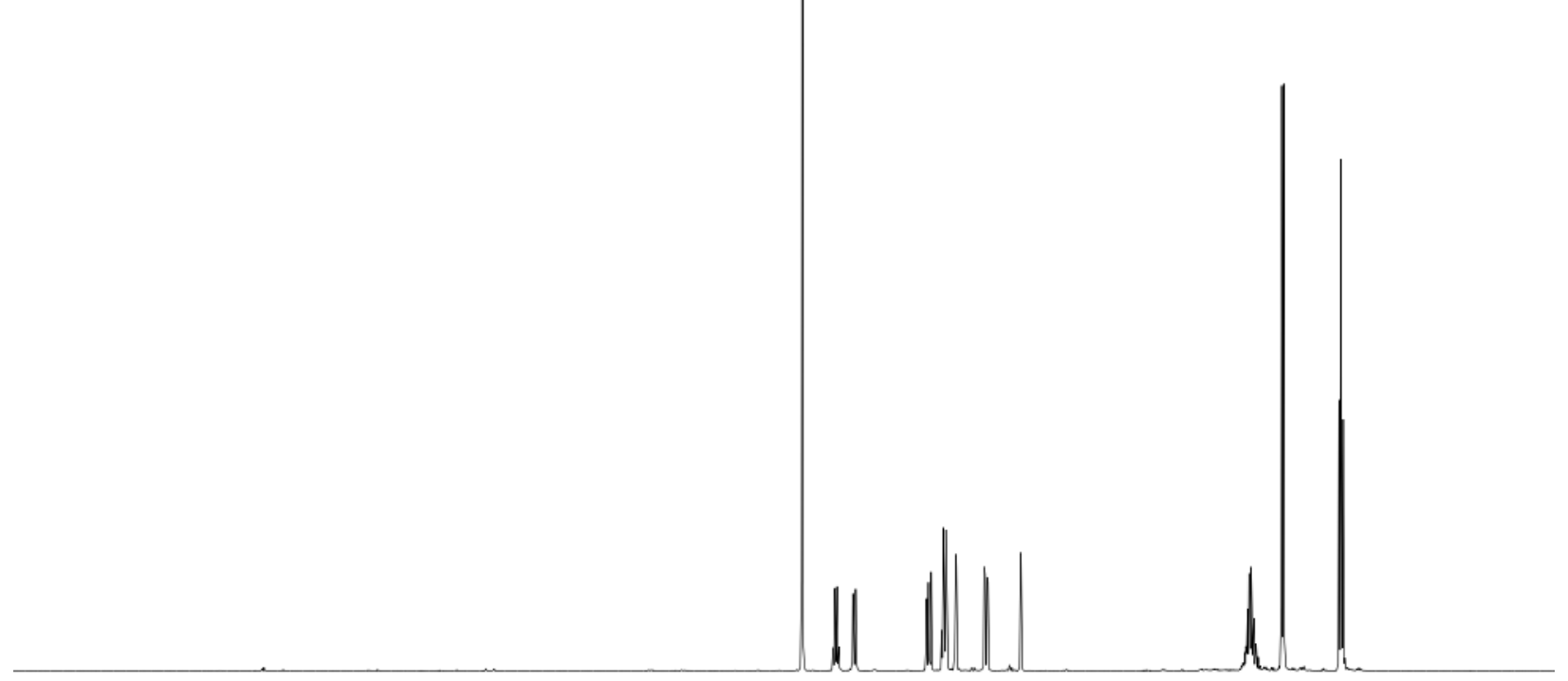

$\begin{array}{lllllllllllllllllllllll}10.0 & 9.5 & 9.0 & 8.5 & 8.0 & 7.5 & 7.0 & 6.5 & 6.0 & 5.5 \underset{\mathrm{f} 1}{(\mathrm{ppm})} \mathbf{5 . 0} & 4.5 & 4.0 & 3.5 & 3.0 & 2.5 & 2.0 & 1.5 & 1.0 & 0.5 & 0.0 & -0\end{array}$

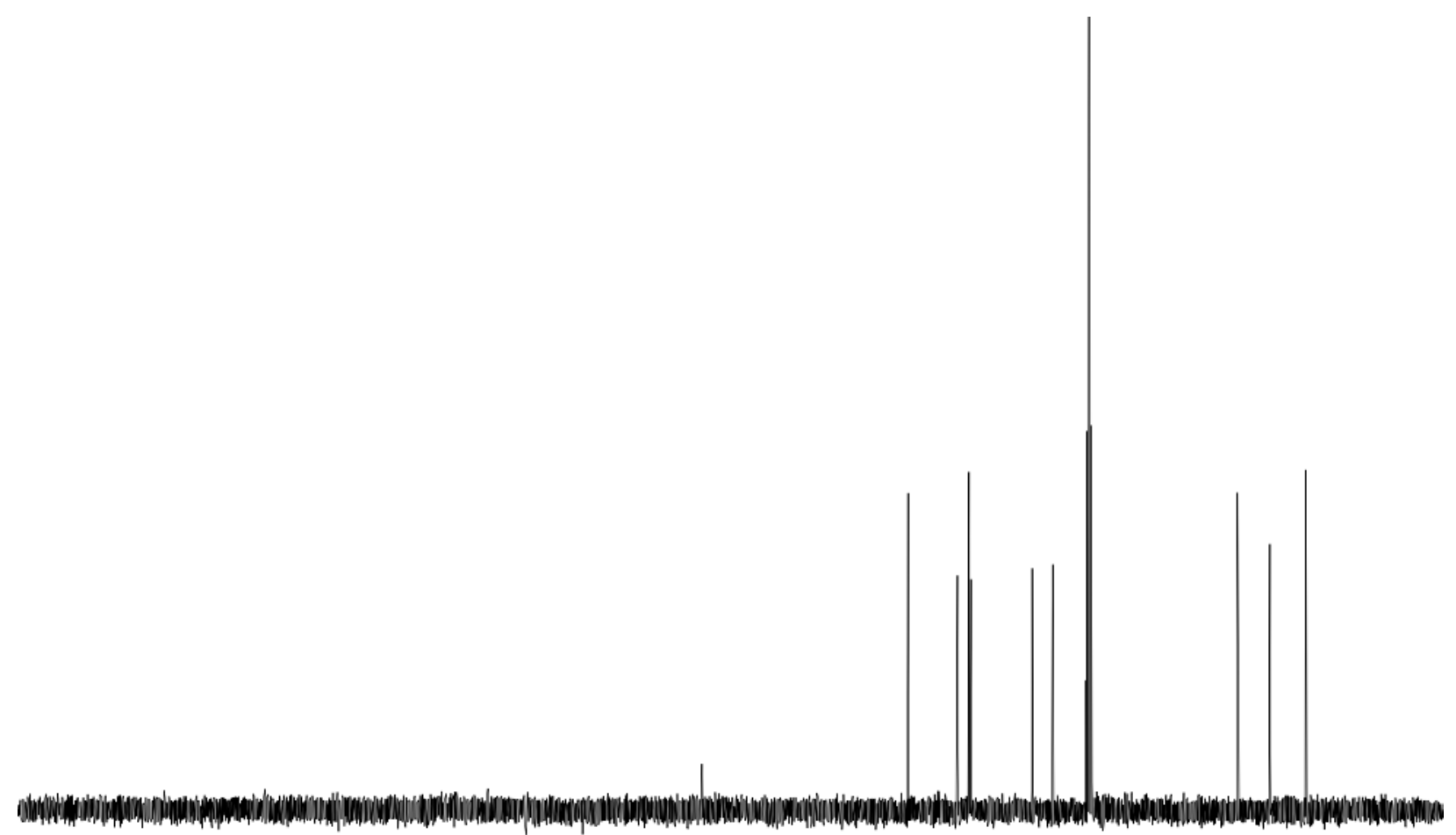

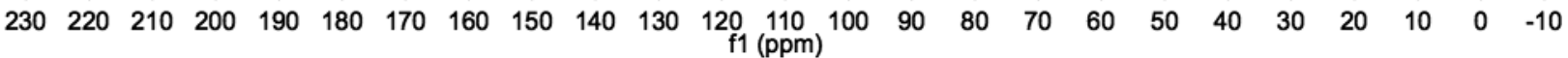




$$
\underbrace{\mathrm{HO}_{3} \mathrm{C}}_{\mathrm{HO}}
$$
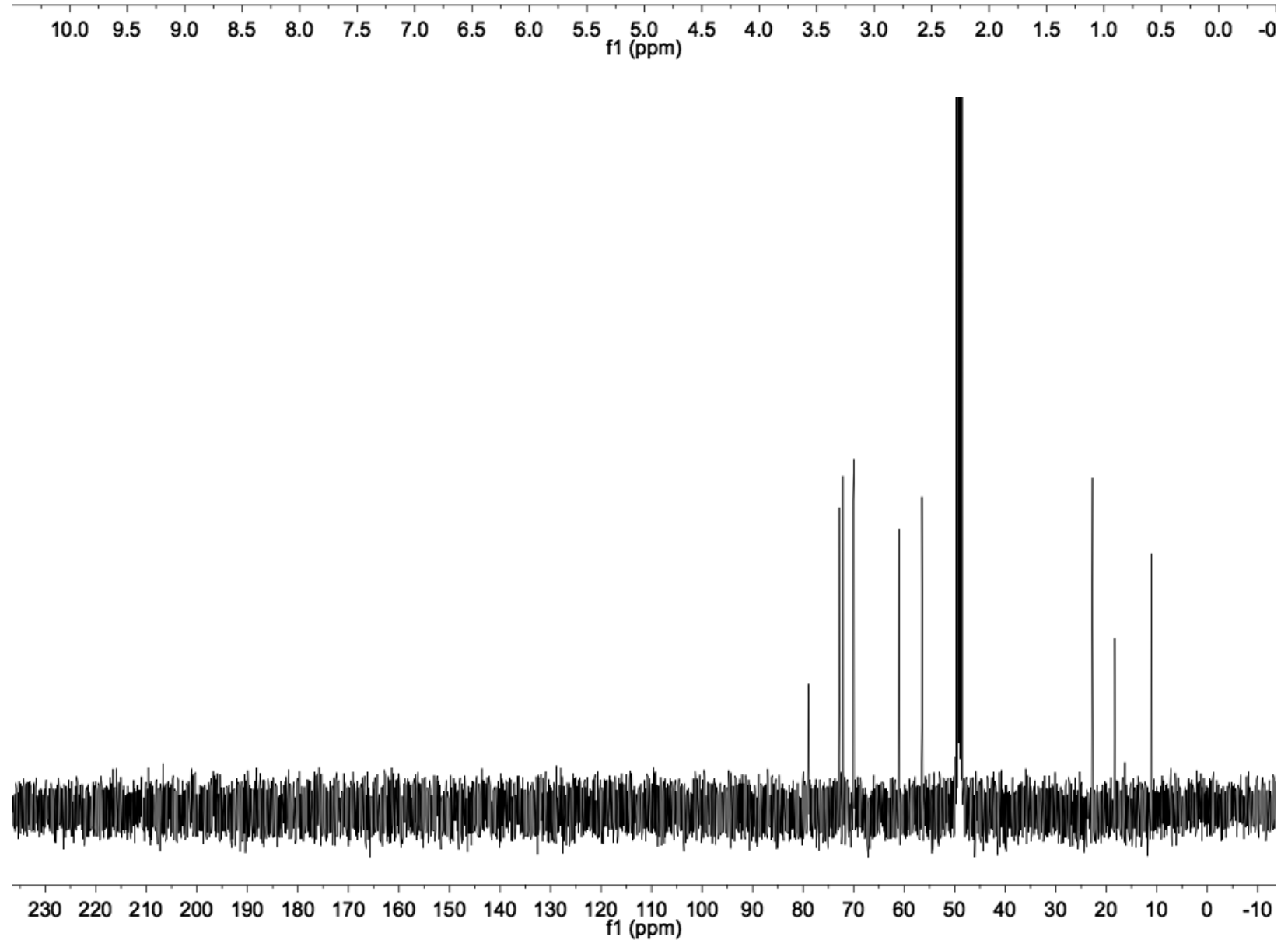

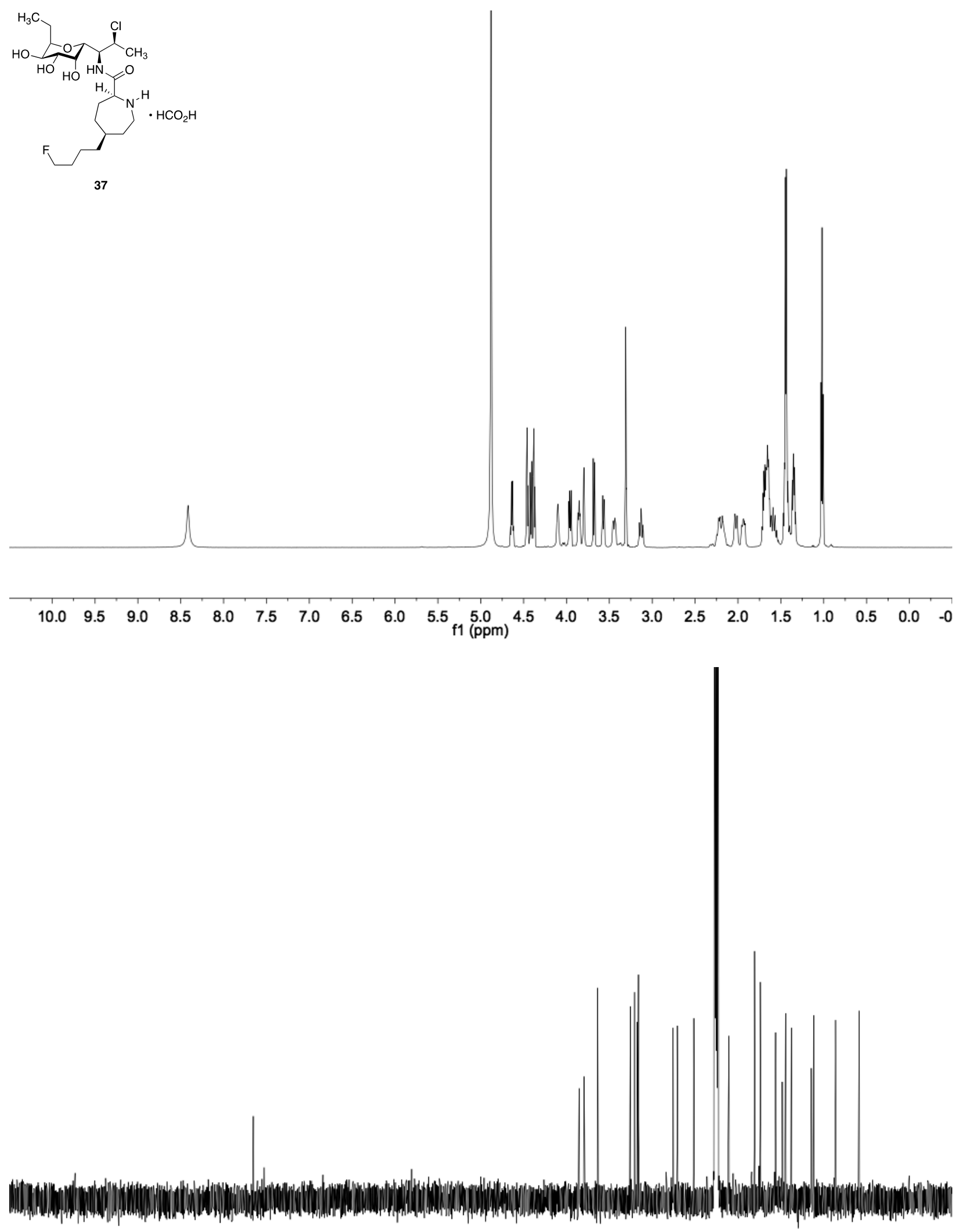

$\begin{array}{llllllllllllllllllllllllll}230 & 220 & 210 & 200 & 190 & 180 & 170 & 160 & 150 & 140 & 130 & 120 & 110 & 100 & 90 & 80 & 70 & 60 & 50 & 40 & 30 & 20 & 10 & 0 & -10\end{array}$ 


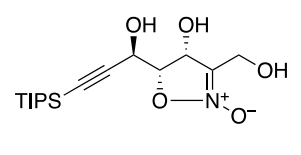

39

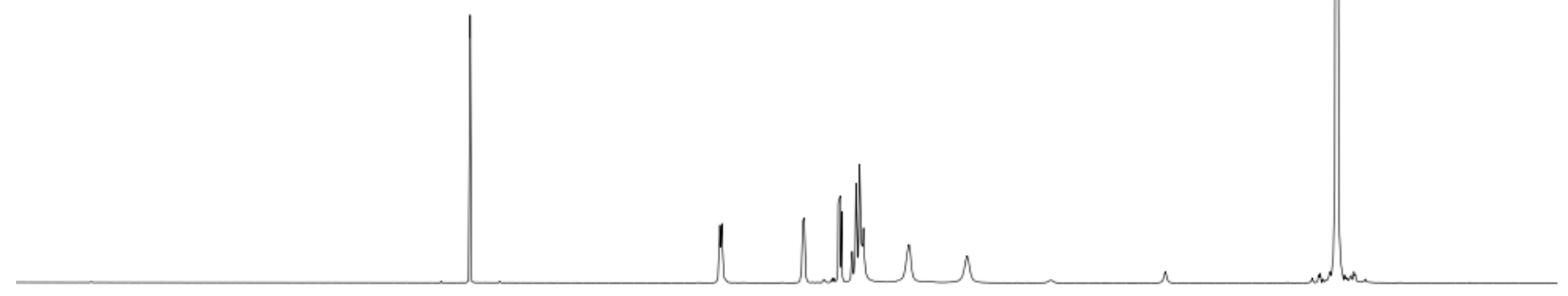

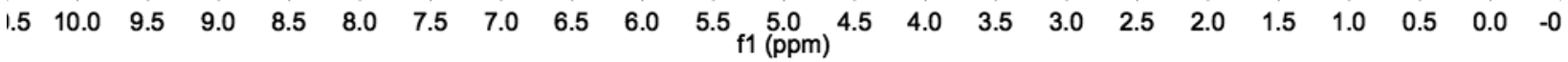

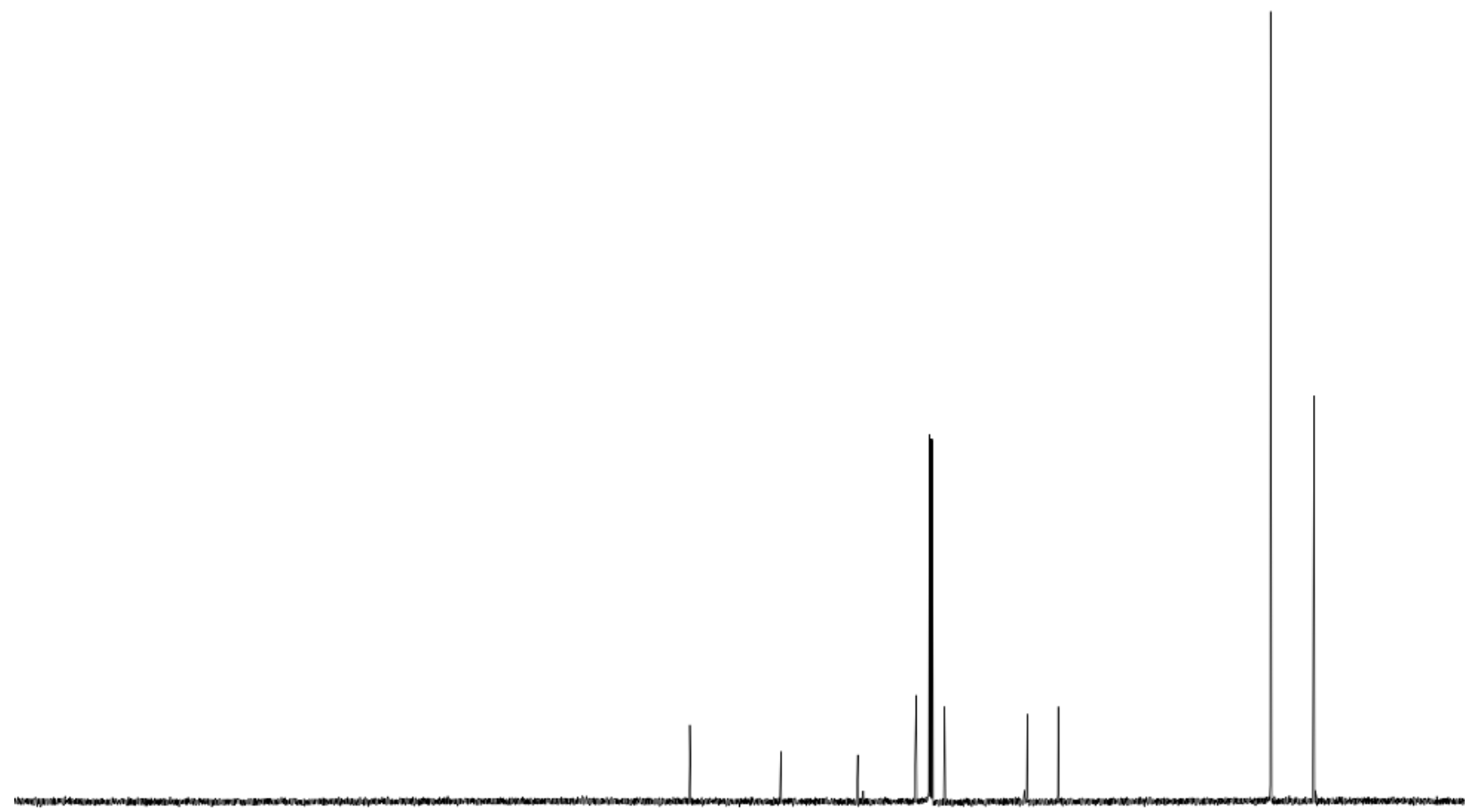

$\begin{array}{llllllllllllllllllllllllllllllllll}230 & 220 & 210 & 200 & 190 & 180 & 170 & 160 & 150 & 140 & 130 & 120 & 110 & 100 & 90 & 80 & 70 & 60 & 50 & 40 & 30 & 20 & 10 & 0 & -10\end{array}$ 

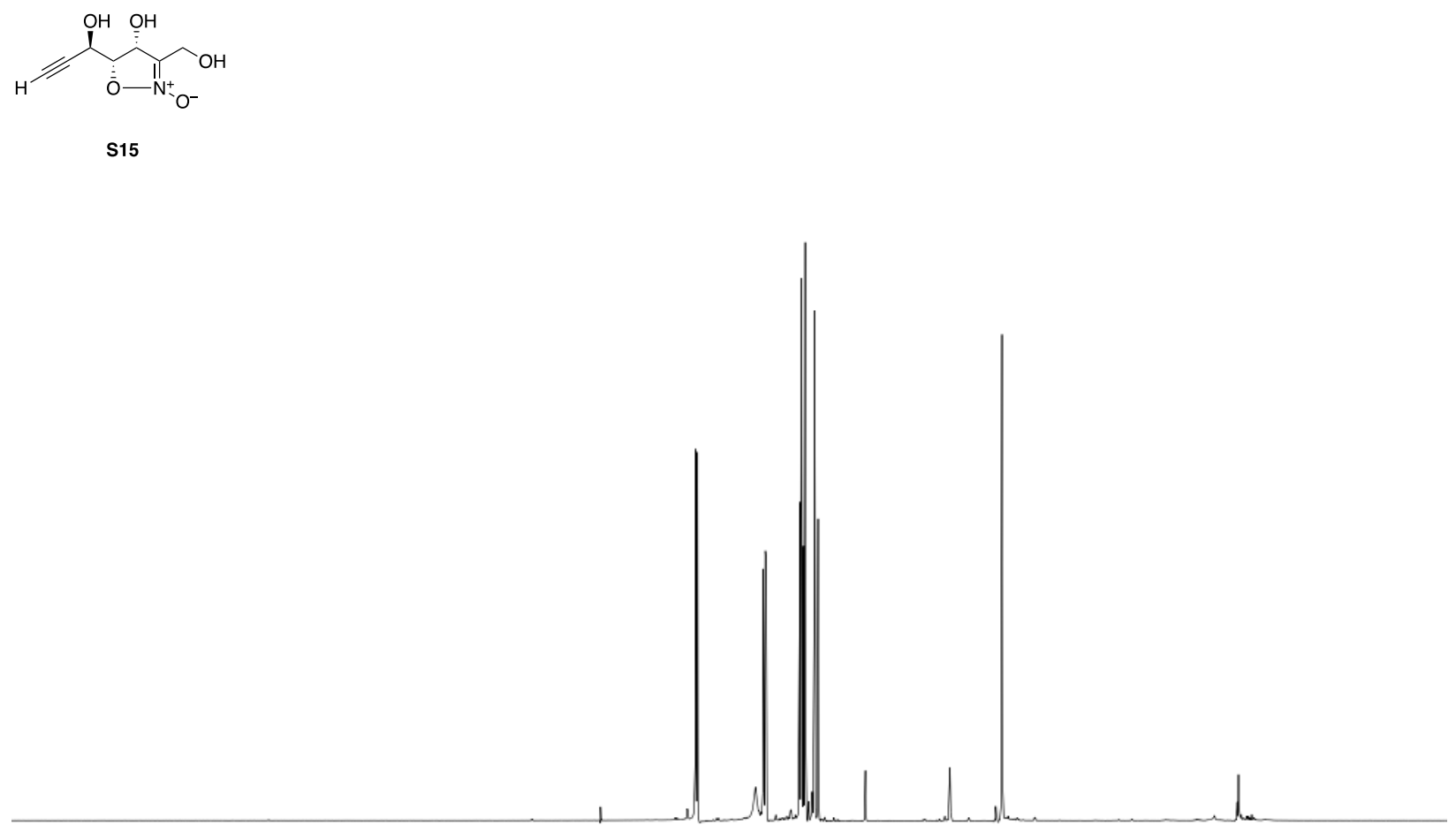

\begin{tabular}{lllllllllllllllllllllll}
\hline .5 & 10.0 & 9.5 & 9.0 & 8.5 & 8.0 & 7.5 & 7.0 & 6.5 & 6.0 & $5.5 \underset{\mathrm{f} 1}{\mathrm{f}} \mathbf{( \mathrm { ppm } )}$ & 4.5 & 4.0 & 3.5 & 3.0 & 2.5 & 2.0 & 1.5 & 1.0 & 0.5 & 0.0 & -0
\end{tabular}

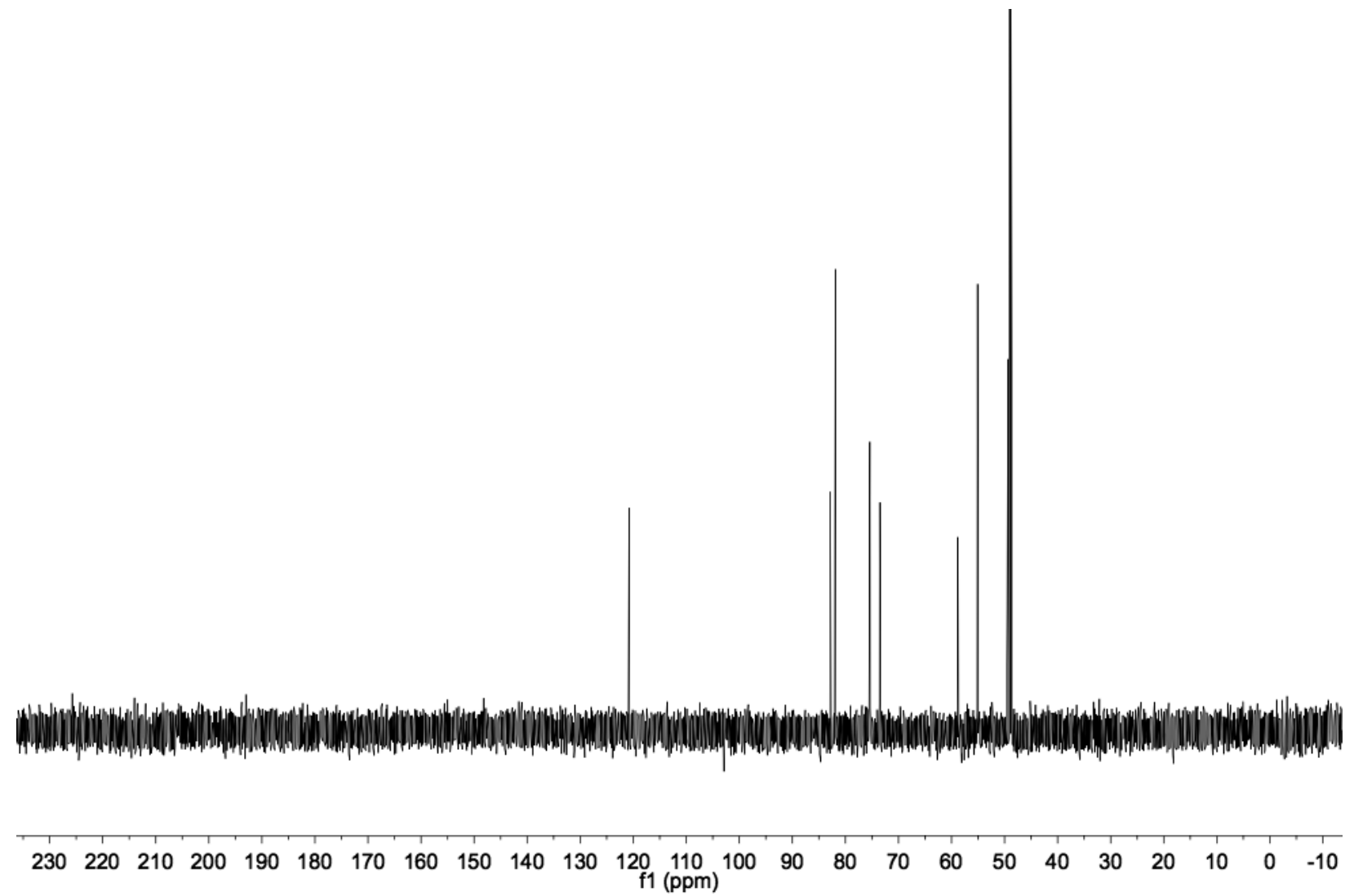




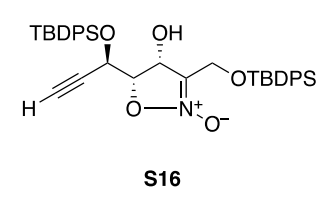

S16

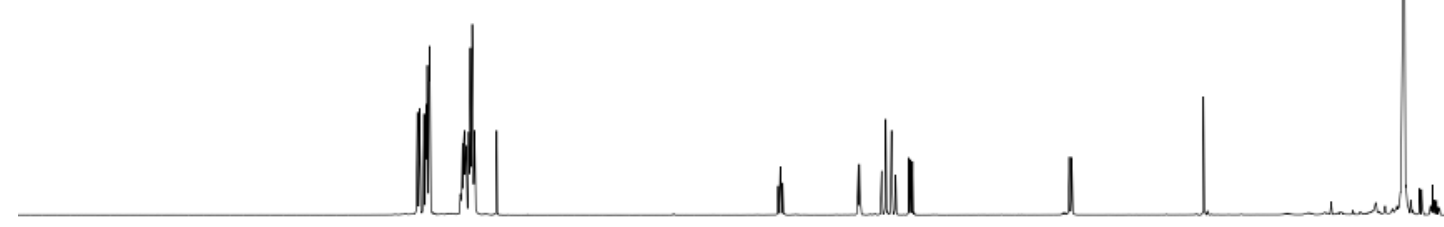

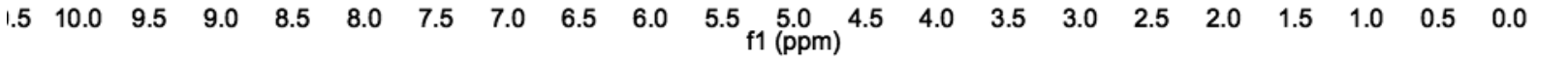

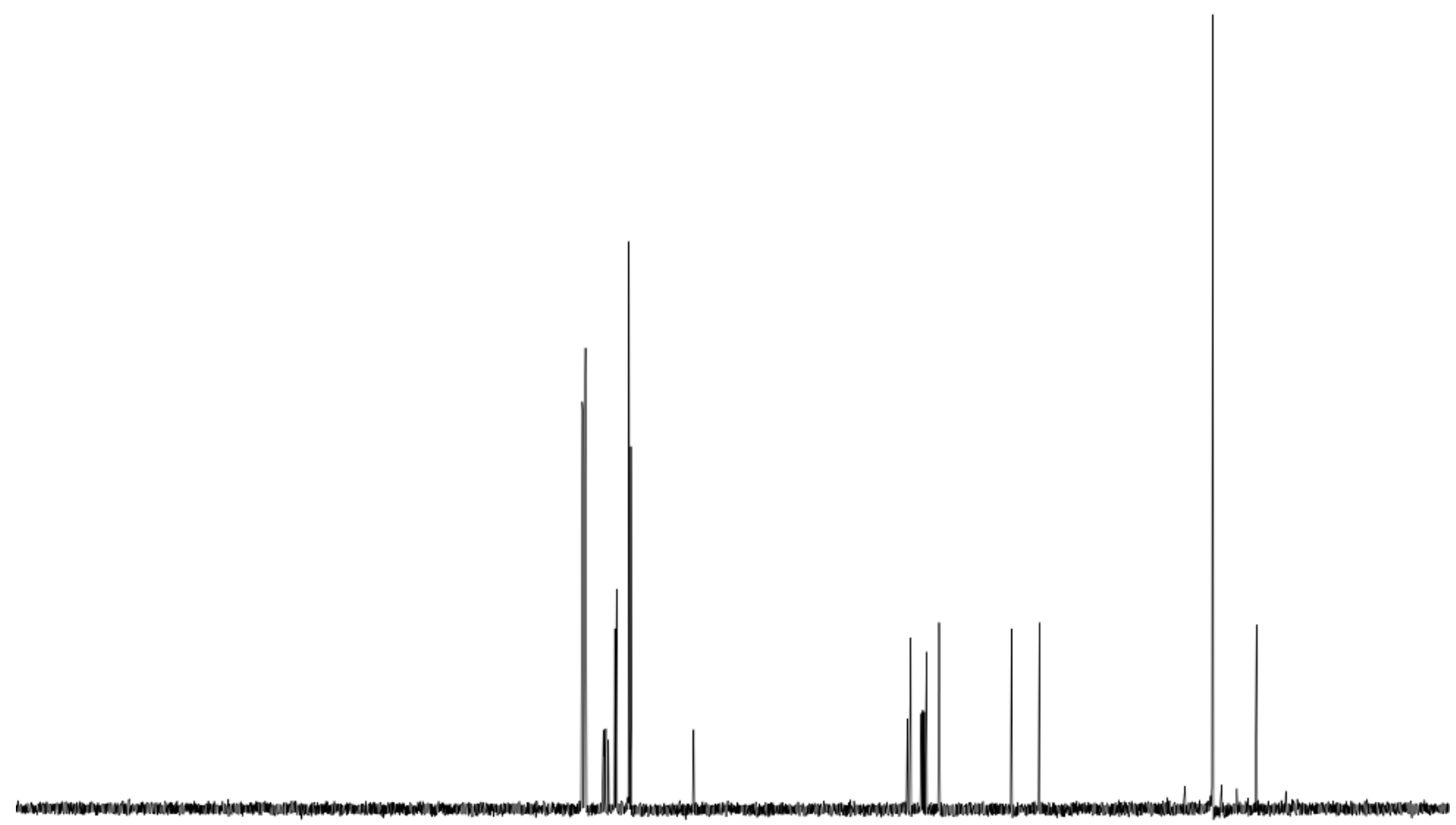

$\begin{array}{lllllllllllllllllllllllll}230 & 220 & 210 & 200 & 190 & 180 & 170 & 160 & 150 & 140 & 130 & 120 & 110 & 100 & 90 & 80 & 70 & 60 & 50 & 40 & 30 & 20 & 10 & 0 & -10\end{array}$ 

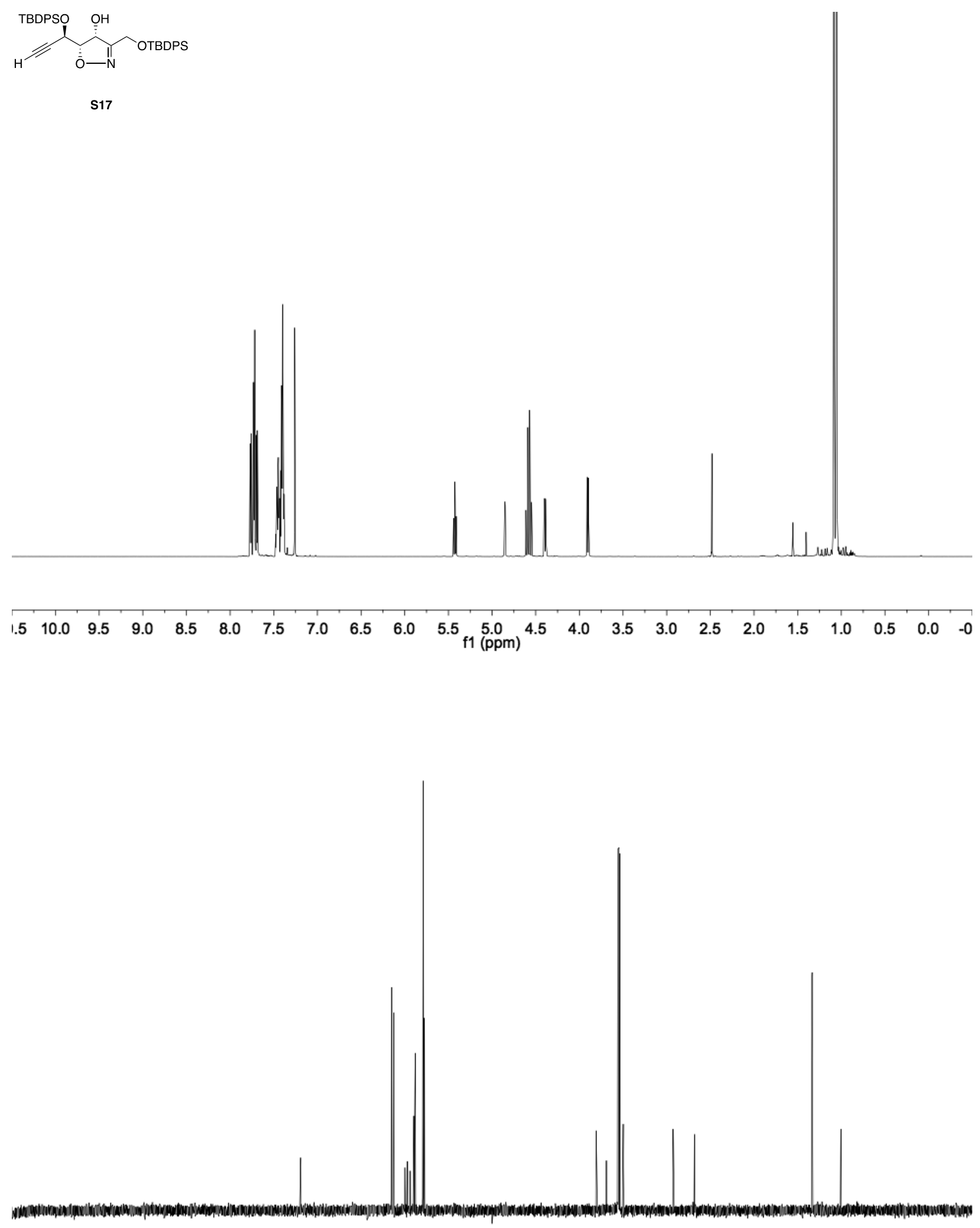

$\begin{array}{llllllllllllllllllllllllllllllll}230 & 220 & 210 & 200 & 190 & 180 & 170 & 160 & 150 & 140 & 130 & 120 & 110 & 100 & 90 & 80 & 70 & 60 & 50 & 40 & 30 & 20 & 10 & 0 & -10\end{array}$ 

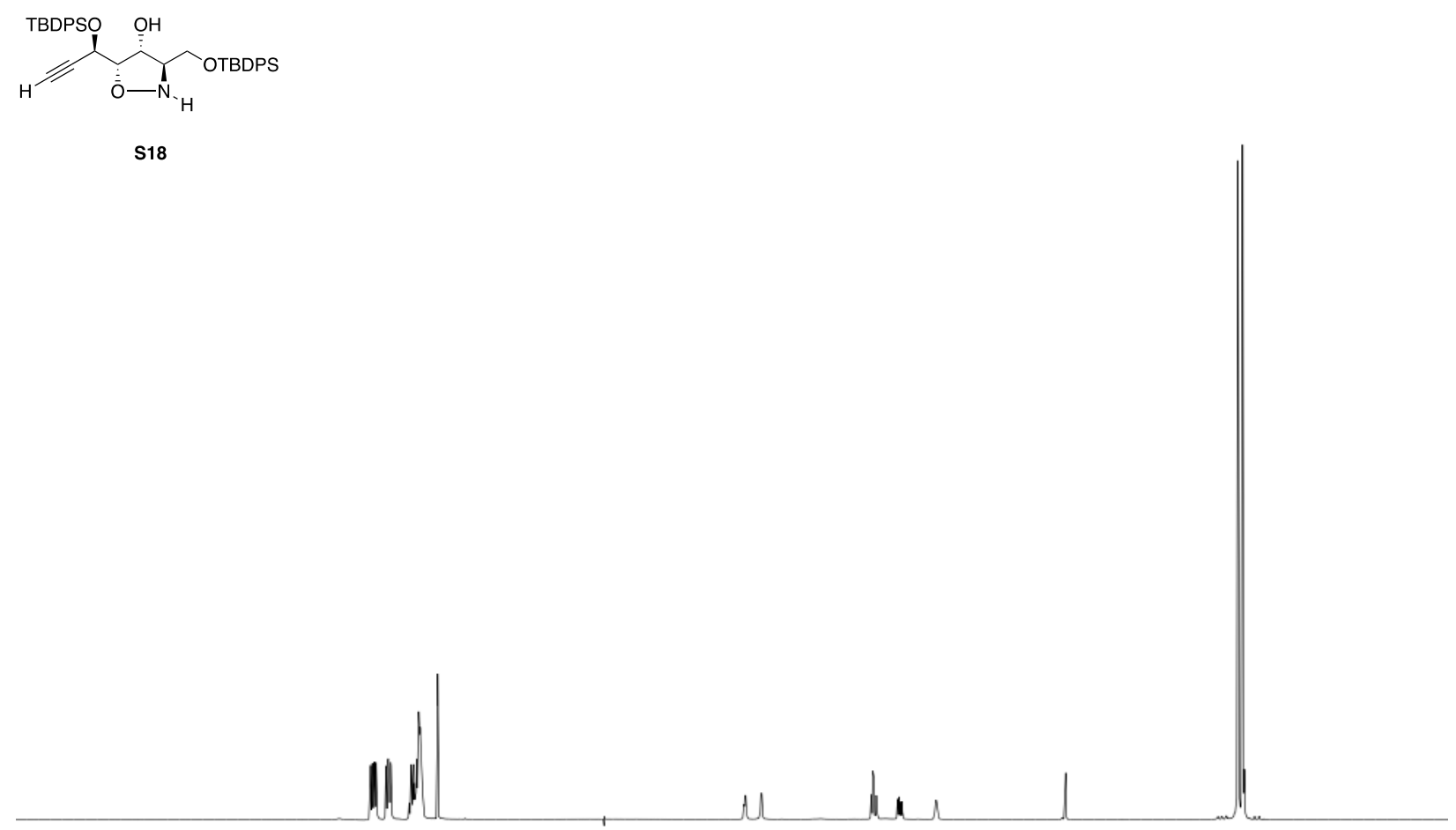

\begin{tabular}{lllllllllllllllllllllll}
\hline .5 & 10.0 & 9.5 & 9.0 & 8.5 & 8.0 & 7.5 & 7.0 & 6.5 & 6.0 & $5.5 \underset{\mathrm{f} 1}{\mathrm{f}} \mathbf{( \mathrm { ppm } )}$ & 4.5 & 4.0 & 3.5 & 3.0 & 2.5 & 2.0 & 1.5 & 1.0 & 0.5 & 0.0 & -0
\end{tabular}

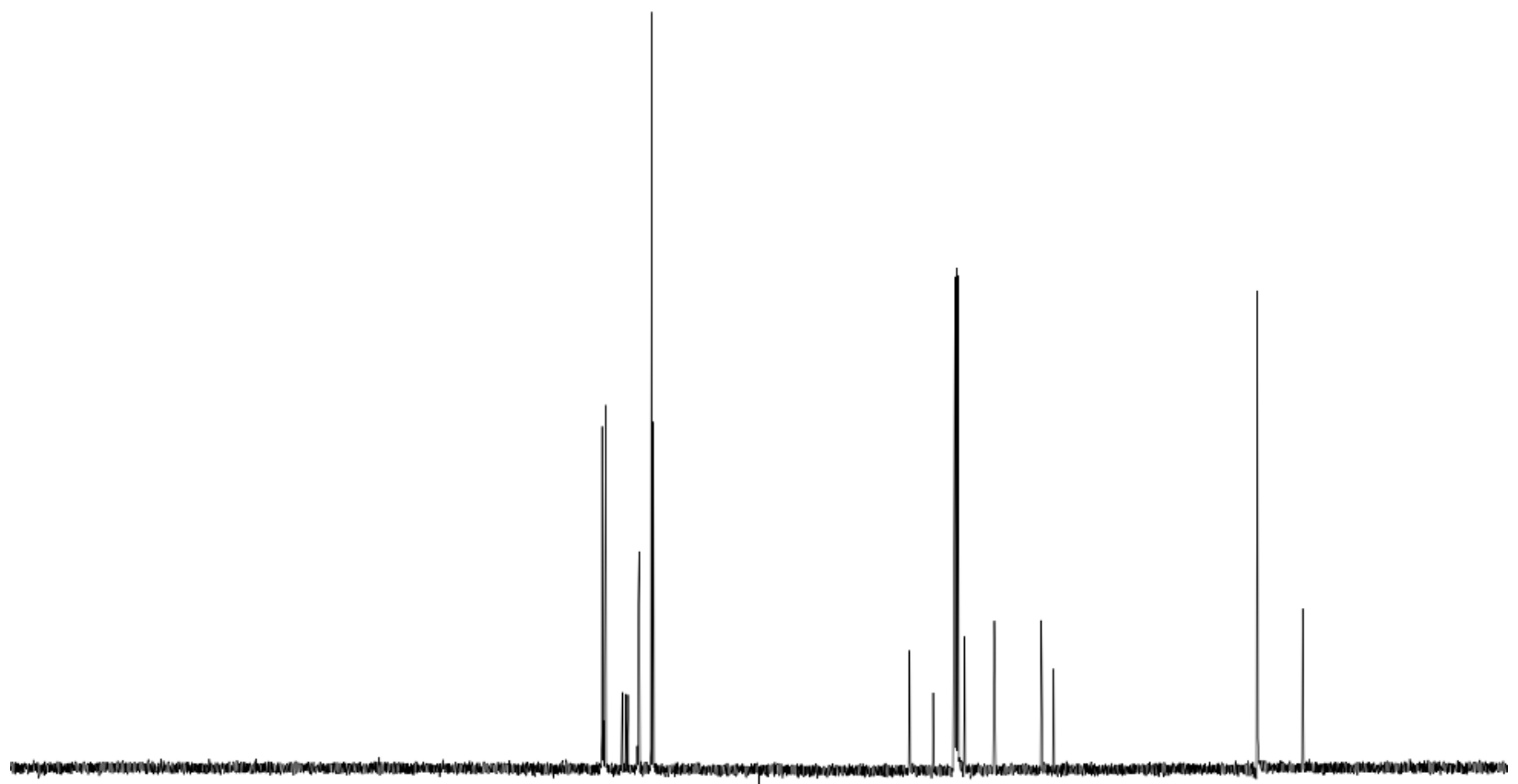

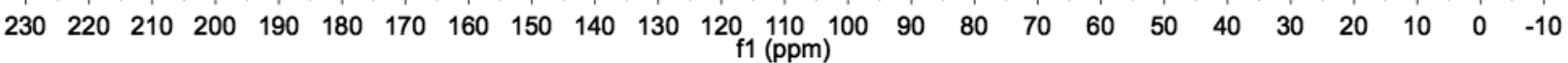



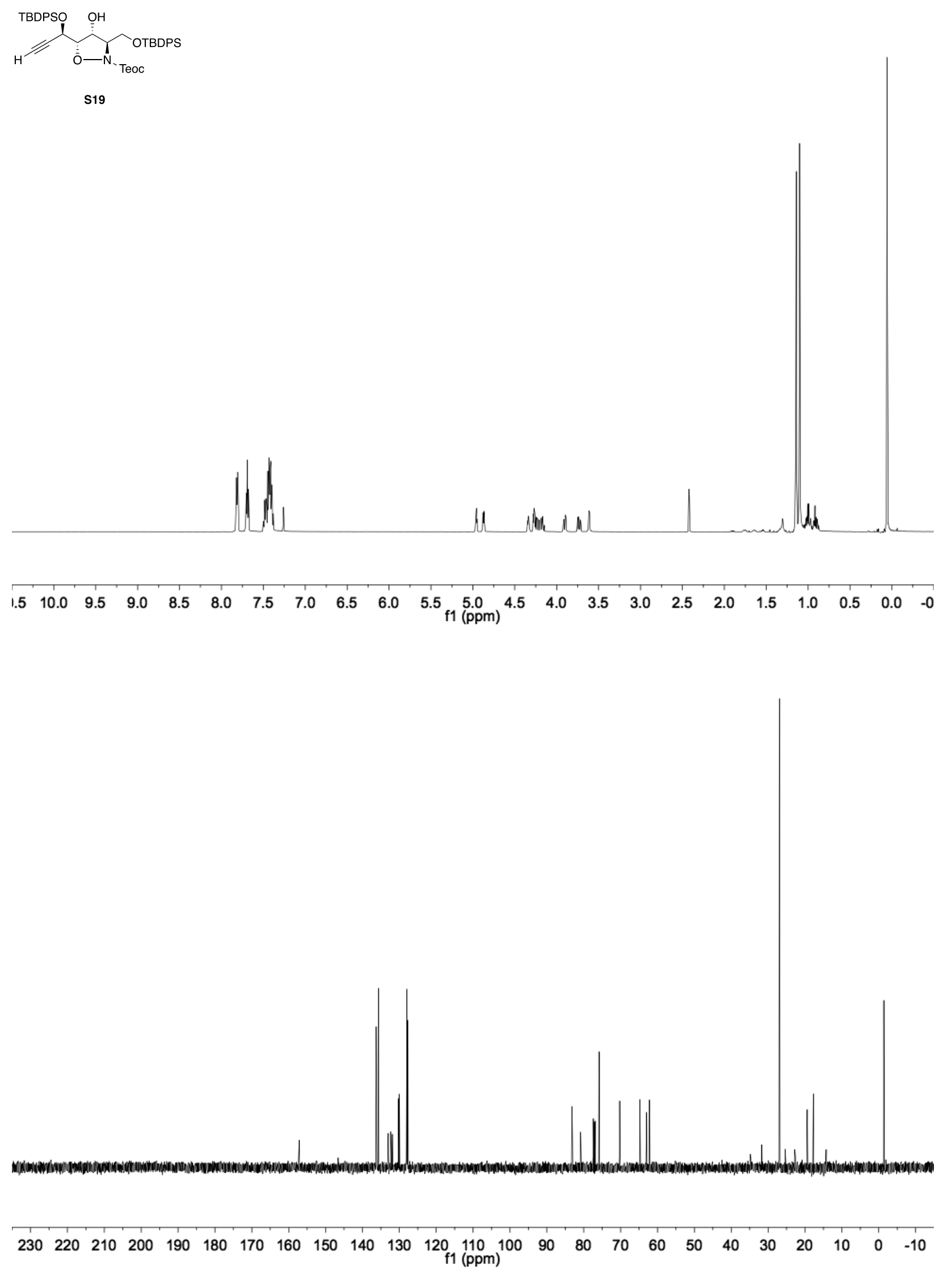

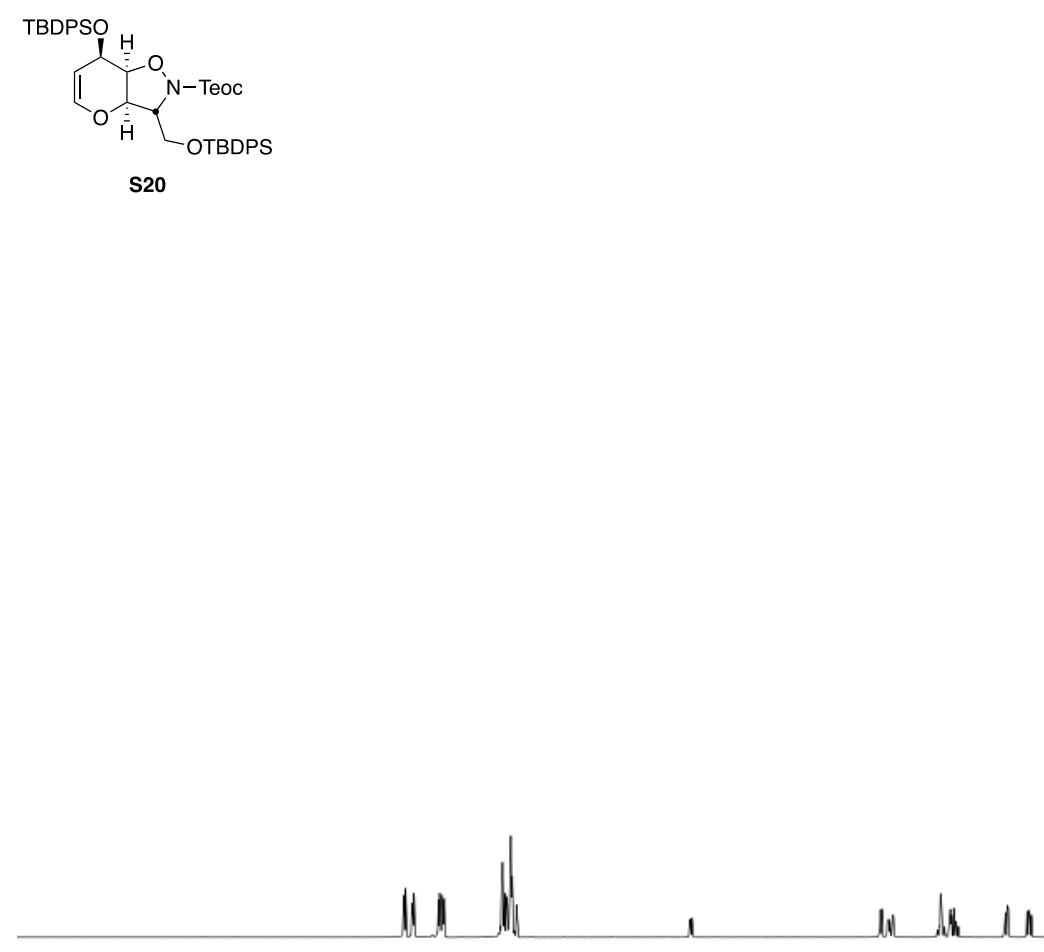

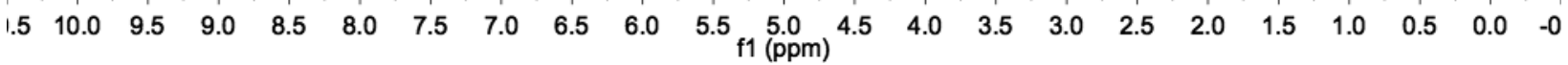

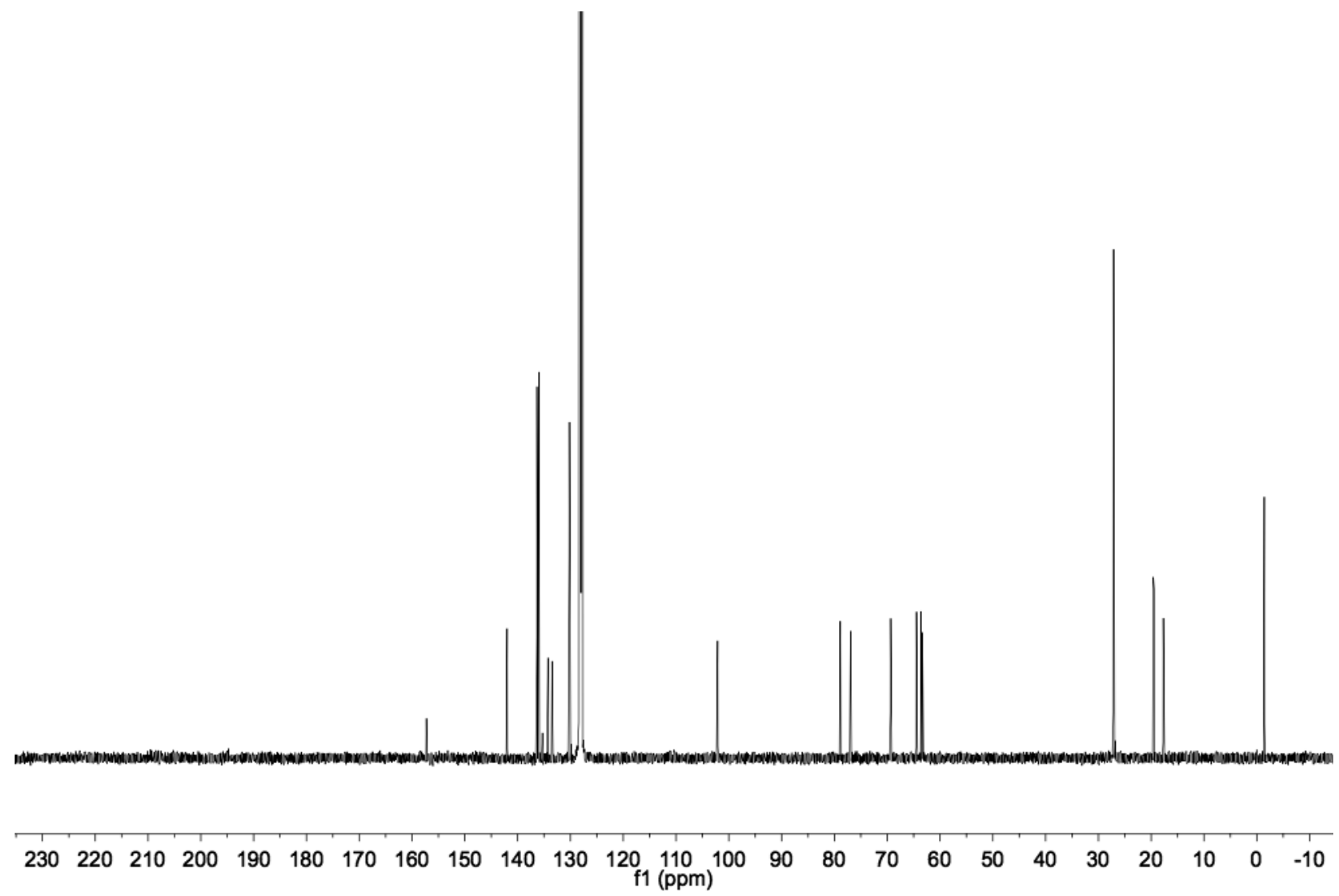



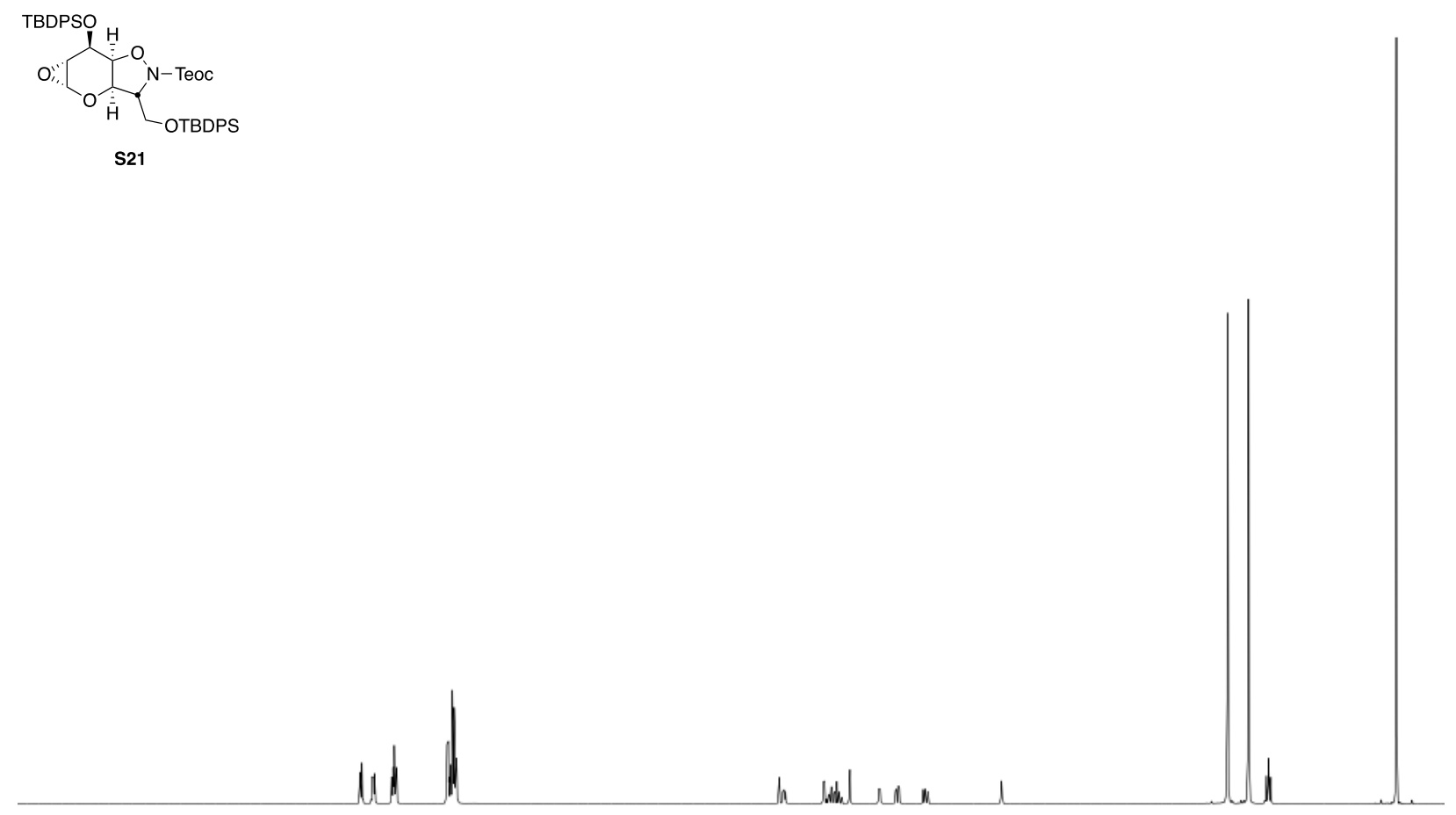

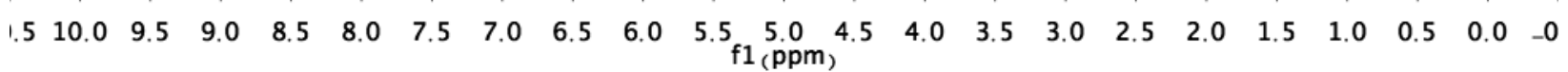

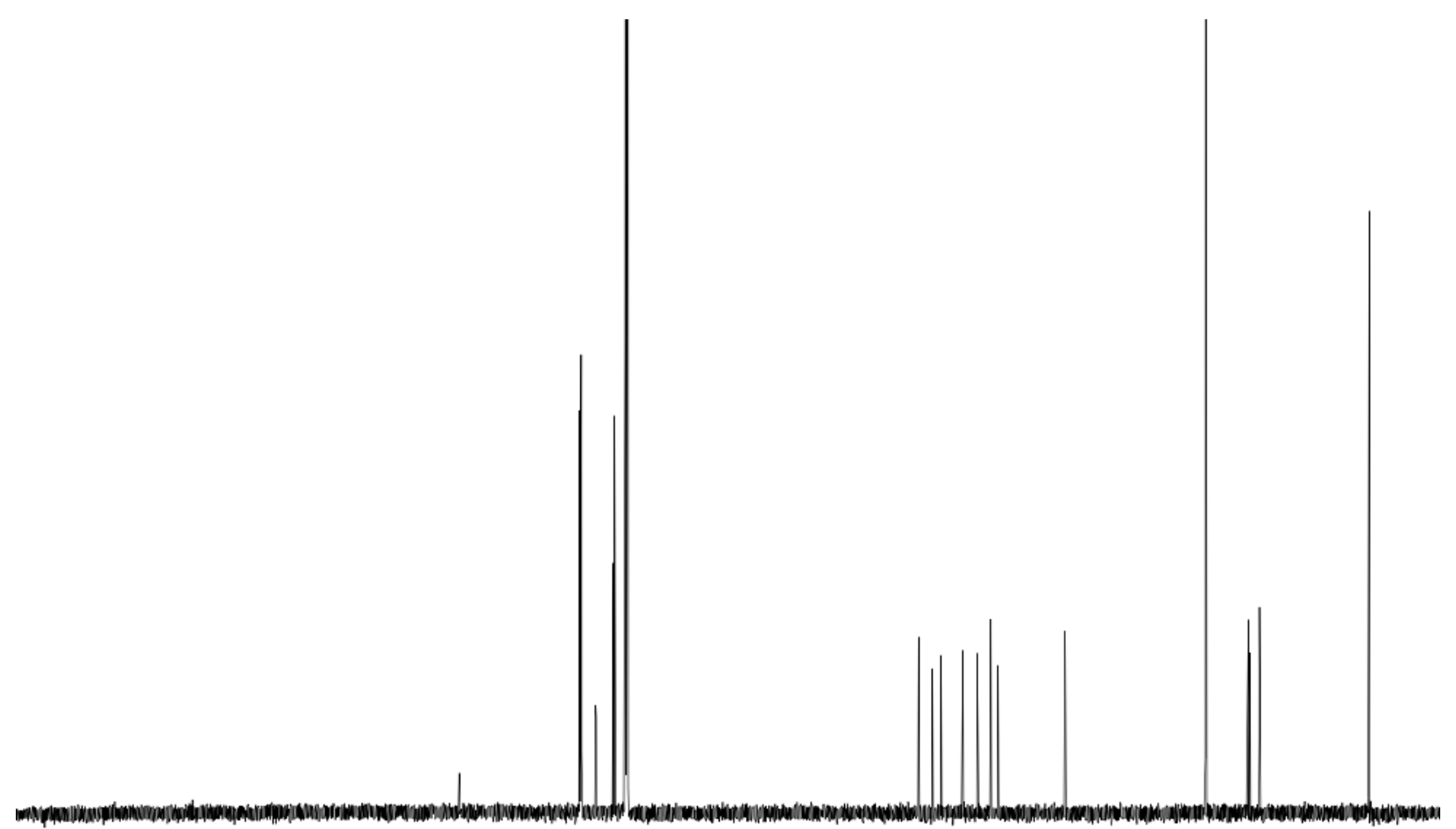

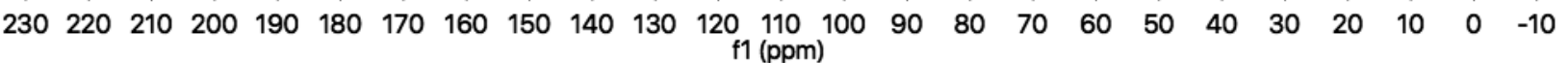




$$
{ }_{\mathrm{S} 22}
$$
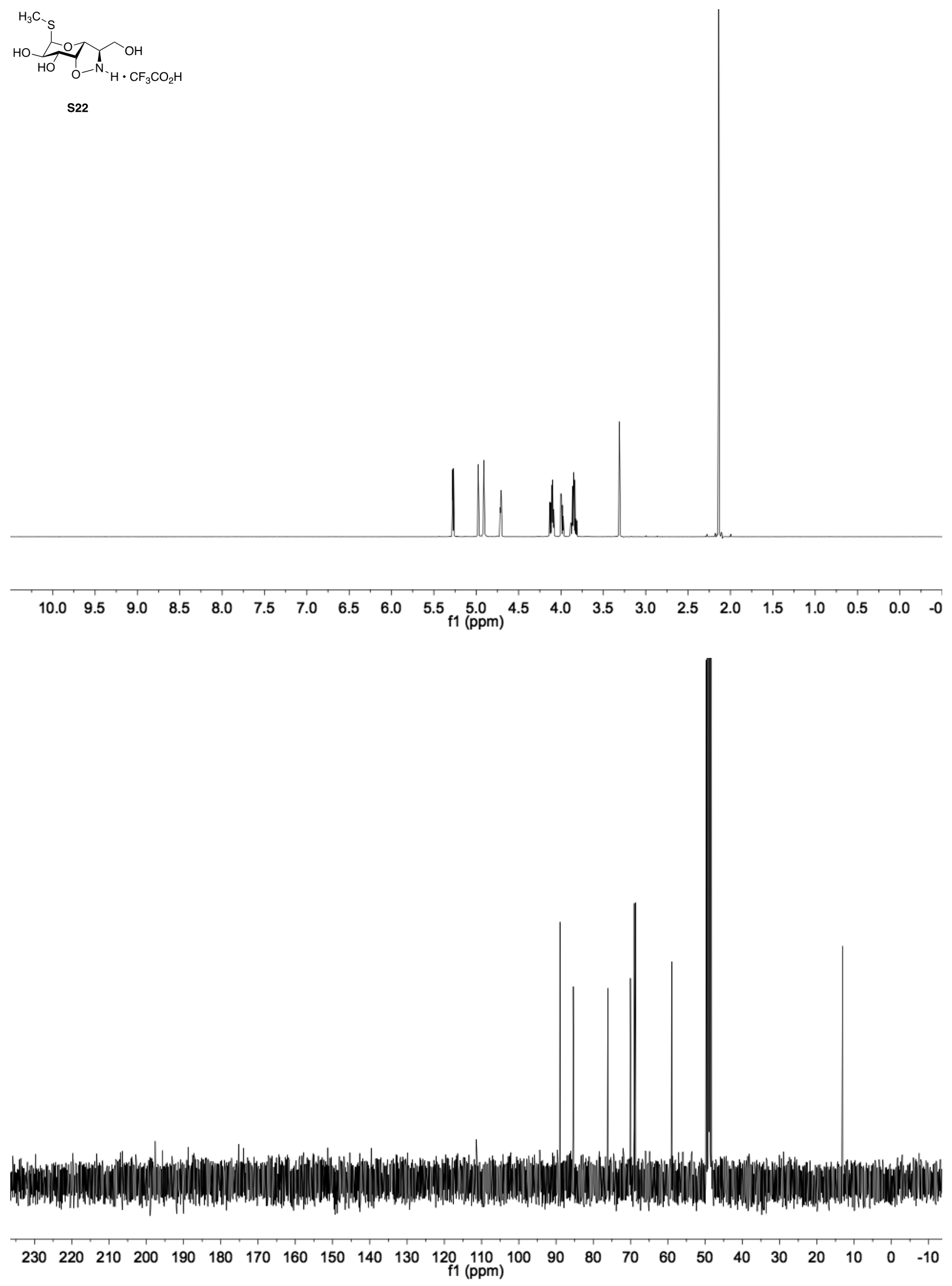


$$
\underbrace{\mathrm{HO}_{\mathrm{HO}}}_{40}
$$

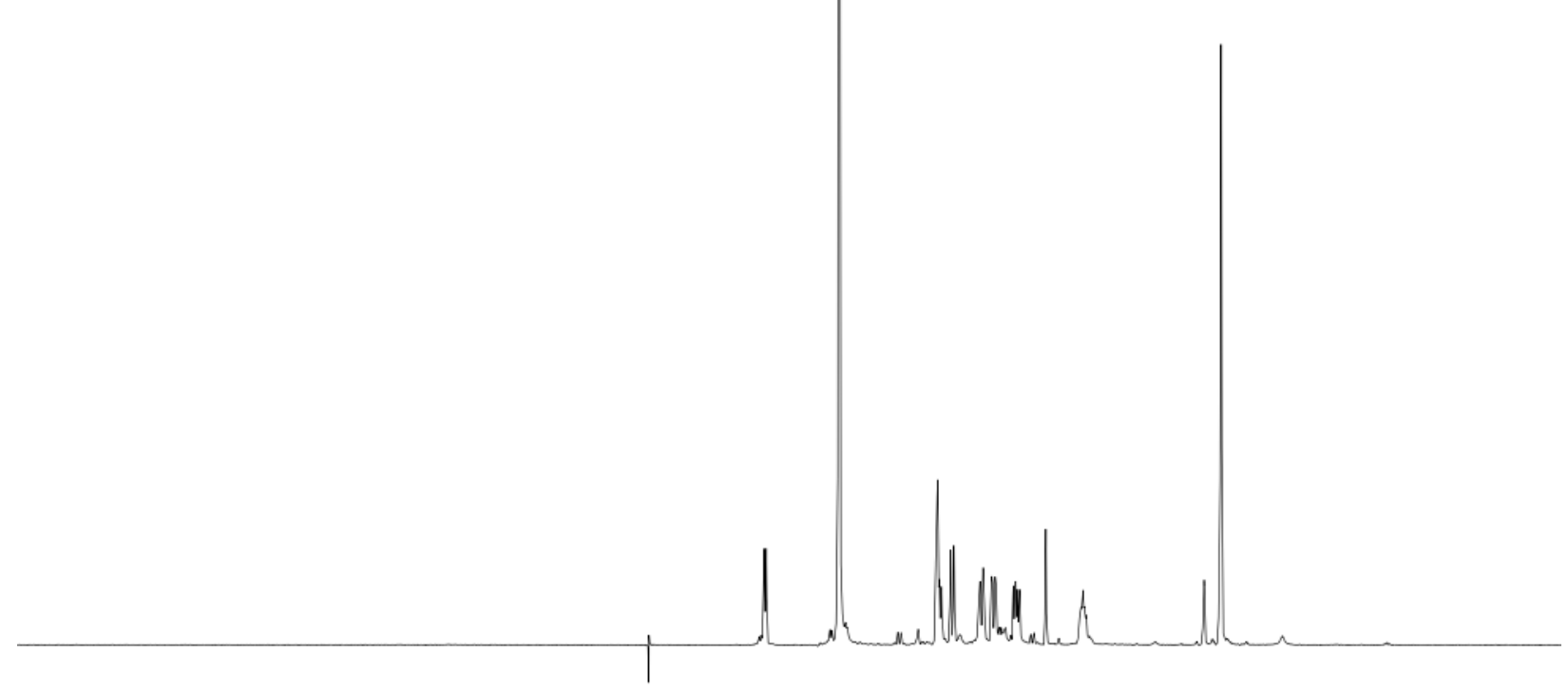

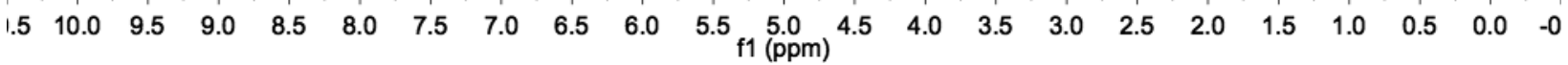

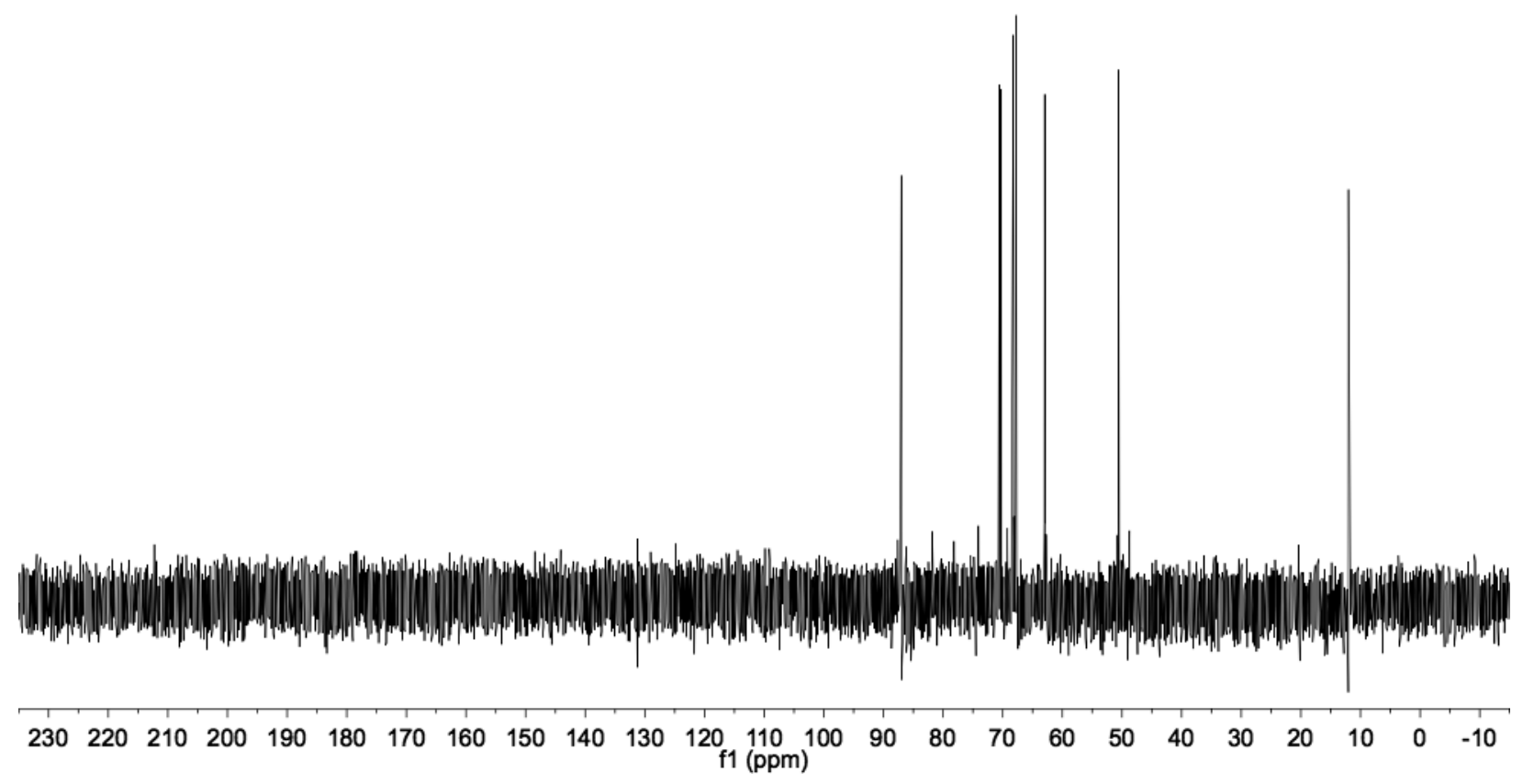



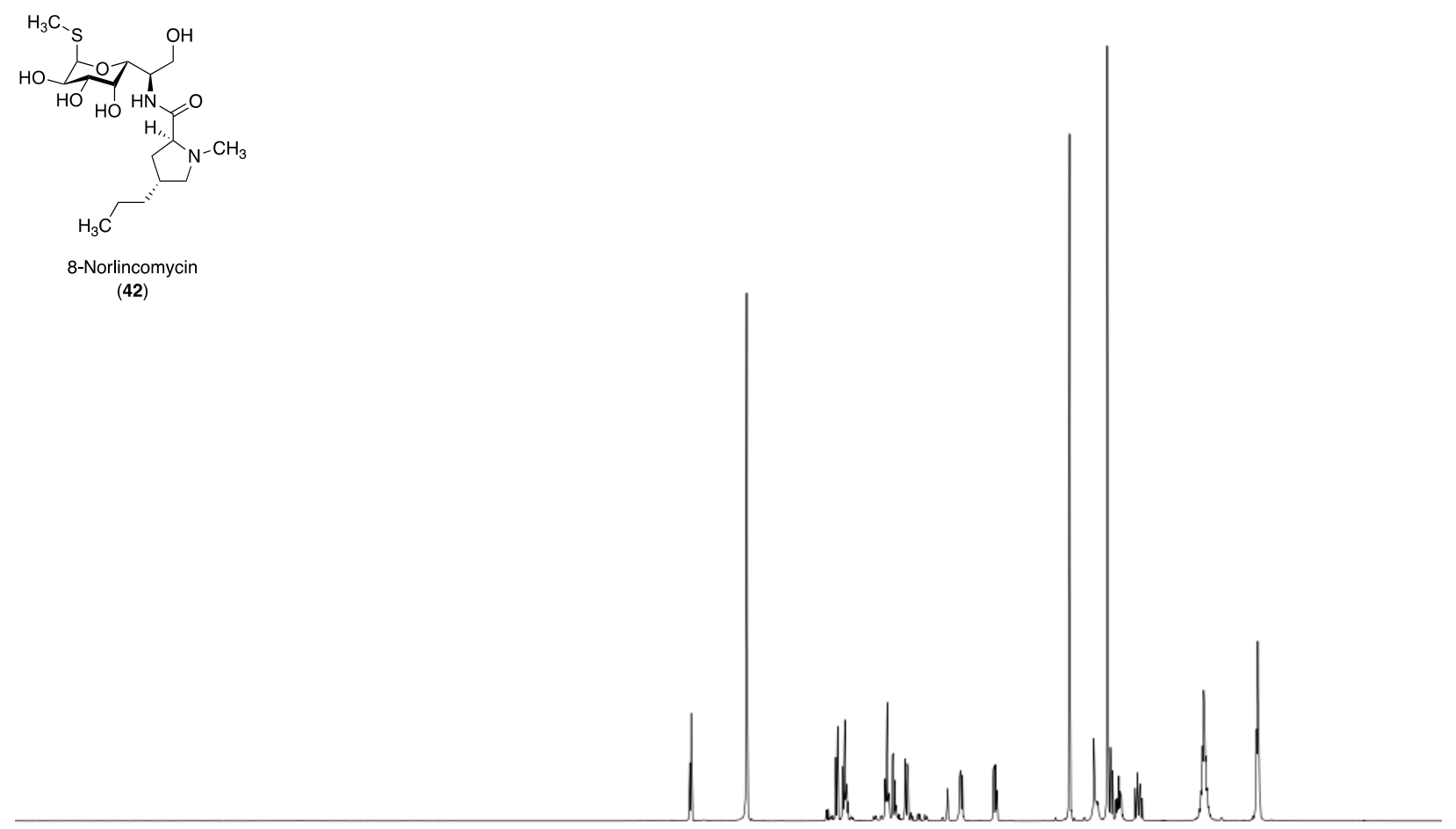

$\begin{array}{lllllllllllllllllllllll}. .5 & 10.0 & 9.5 & 9.0 & 8.5 & 8.0 & 7.5 & 7.0 & 6.5 & 6.0 & 5.5 \underset{\mathrm{f} 1}{\mathrm{f}(\mathrm{ppm})} \mathbf{4 . 0} & 4.0 & 3.5 & 3.0 & 2.5 & 2.0 & 1.5 & 1.0 & 0.5 & 0.0 & -0\end{array}$

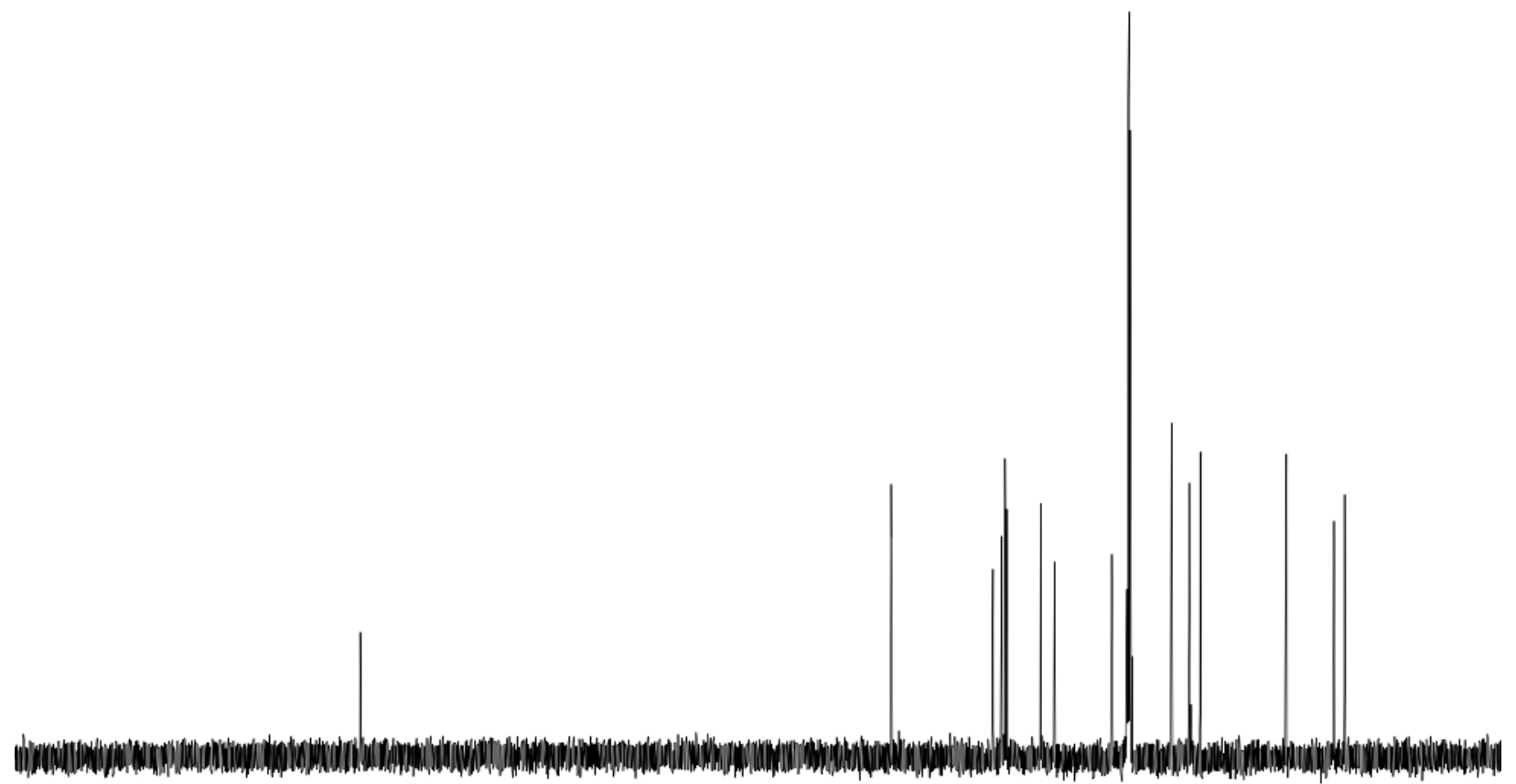

$\begin{array}{lllllllllllllllllllllllll}230 & 220 & 210 & 200 & 190 & 180 & 170 & 160 & 150 & 140 & 130 & \underset{\mathrm{f} 1}{120}(\mathrm{ppm}) & 100 & 90 & 80 & 70 & 60 & 50 & 40 & 30 & 20 & 10 & 0 & -10\end{array}$ 


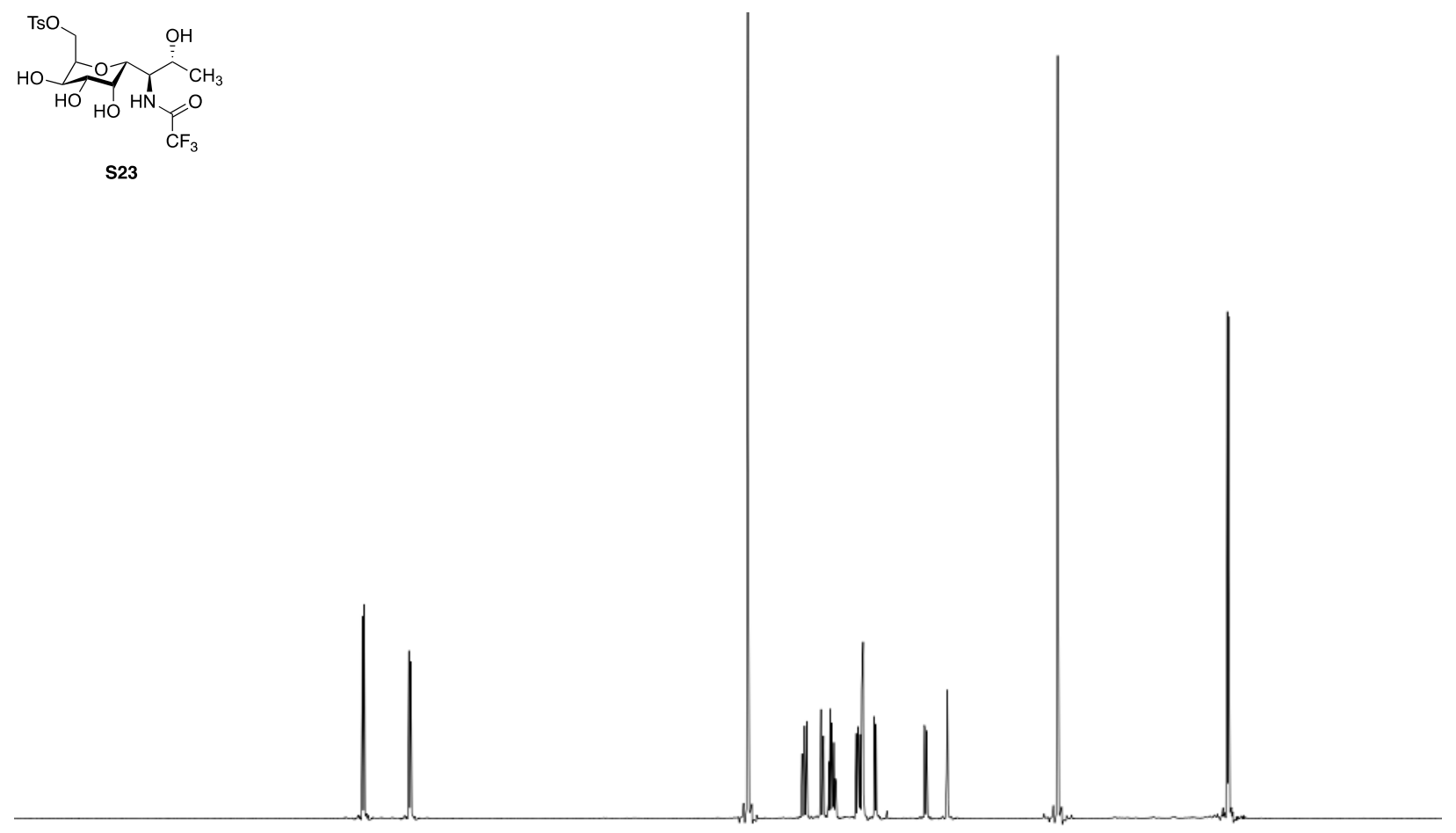

$\begin{array}{lllllllllllllllllllllll}1.5 & 10.0 & 9.5 & 9.0 & 8.5 & 8.0 & 7.5 & 7.0 & 6.5 & 6.0 & 5.5 & \underset{f 1}{(\mathrm{ppm})} & 4.5 & 4.0 & 3.5 & 3.0 & 2.5 & 2.0 & 1.5 & 1.0 & 0.5 & 0.0 & -0\end{array}$

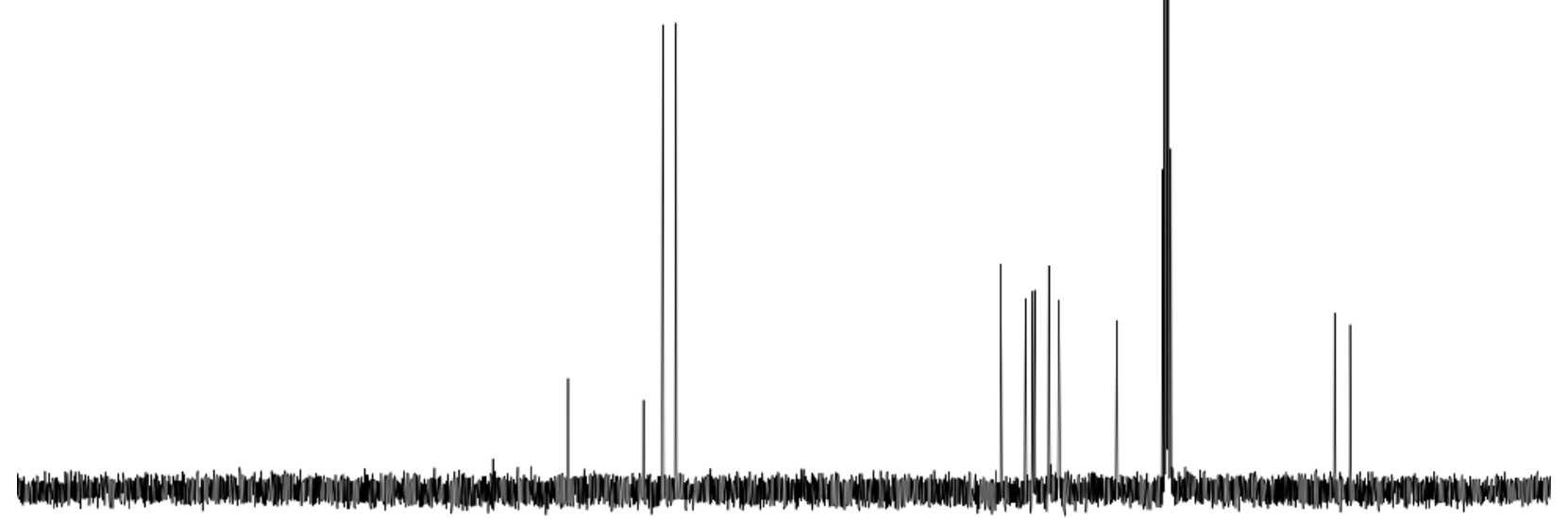

$\begin{array}{lllllllllllllllllllllllll}230 & 220 & 210 & 200 & 190 & 180 & 170 & 160 & 150 & 140 & 130 & 120 \\ \mathrm{f} 1(\mathrm{ppm}) & 100 & 90 & 80 & 70 & 60 & 50 & 40 & 30 & 20 & 10 & 0 & -10\end{array}$ 


$$
\underbrace{\mathrm{N}_{3}}_{\mathrm{S}_{24}}
$$

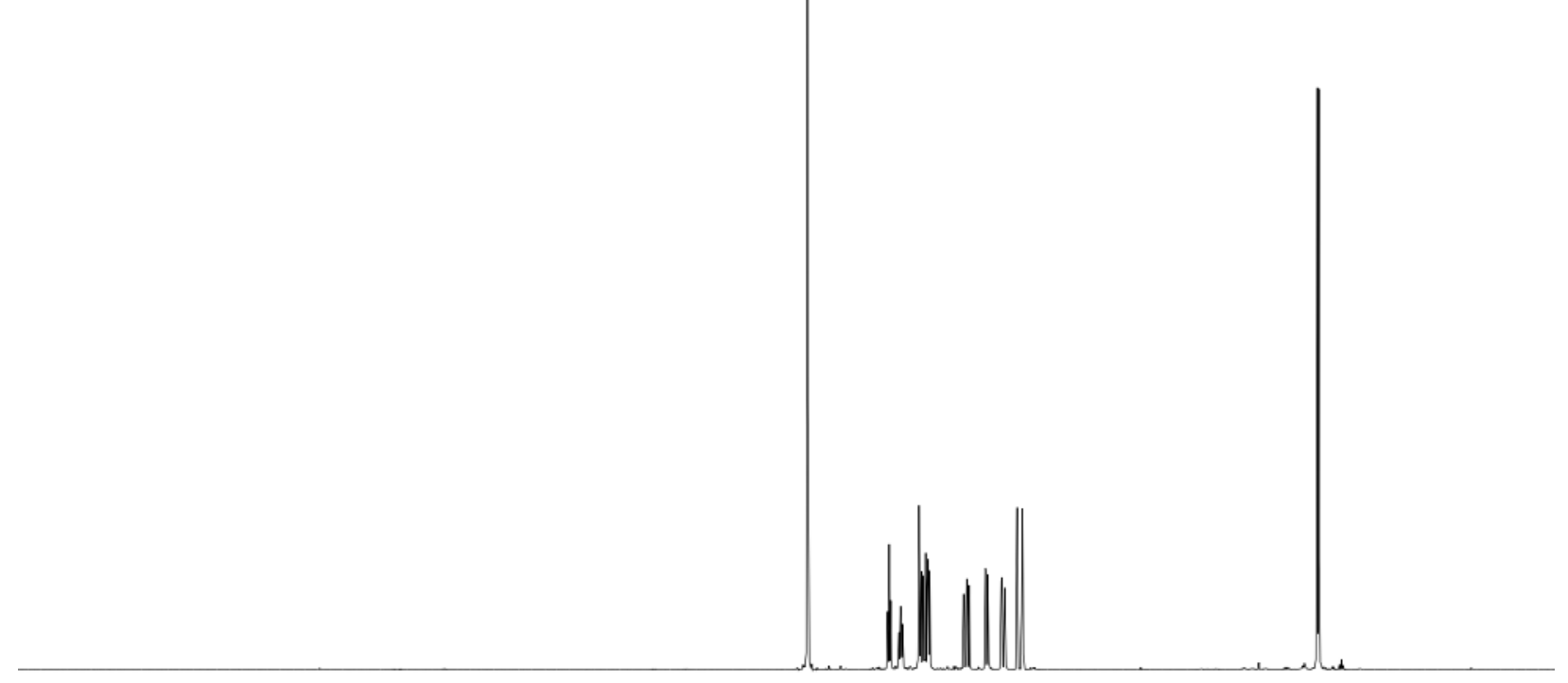

$\begin{array}{llllllllllllllllllllll}10.0 & 9.5 & 9.0 & 8.5 & 8.0 & 7.5 & 7.0 & 6.5 & 6.0 & 5.5 & \underset{\mathrm{f} 1}{(\mathrm{ppm})} \mathbf{5 . 0} & 4.5 & 4.0 & 3.5 & 3.0 & 2.5 & 2.0 & 1.5 & 1.0 & 0.5 & 0.0 & -0\end{array}$

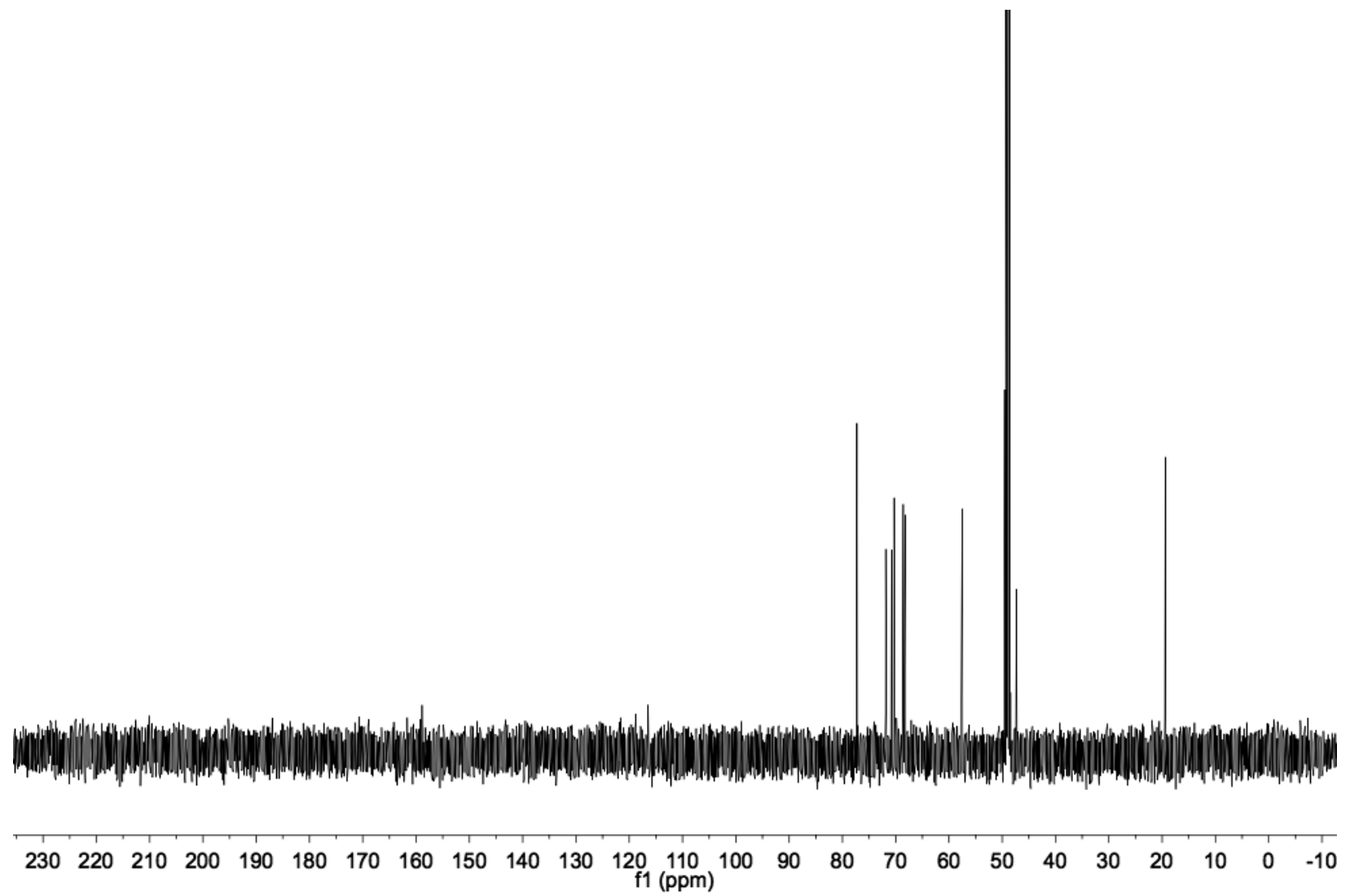




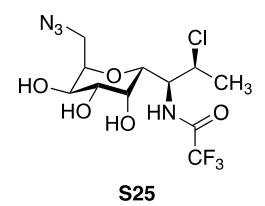

S25
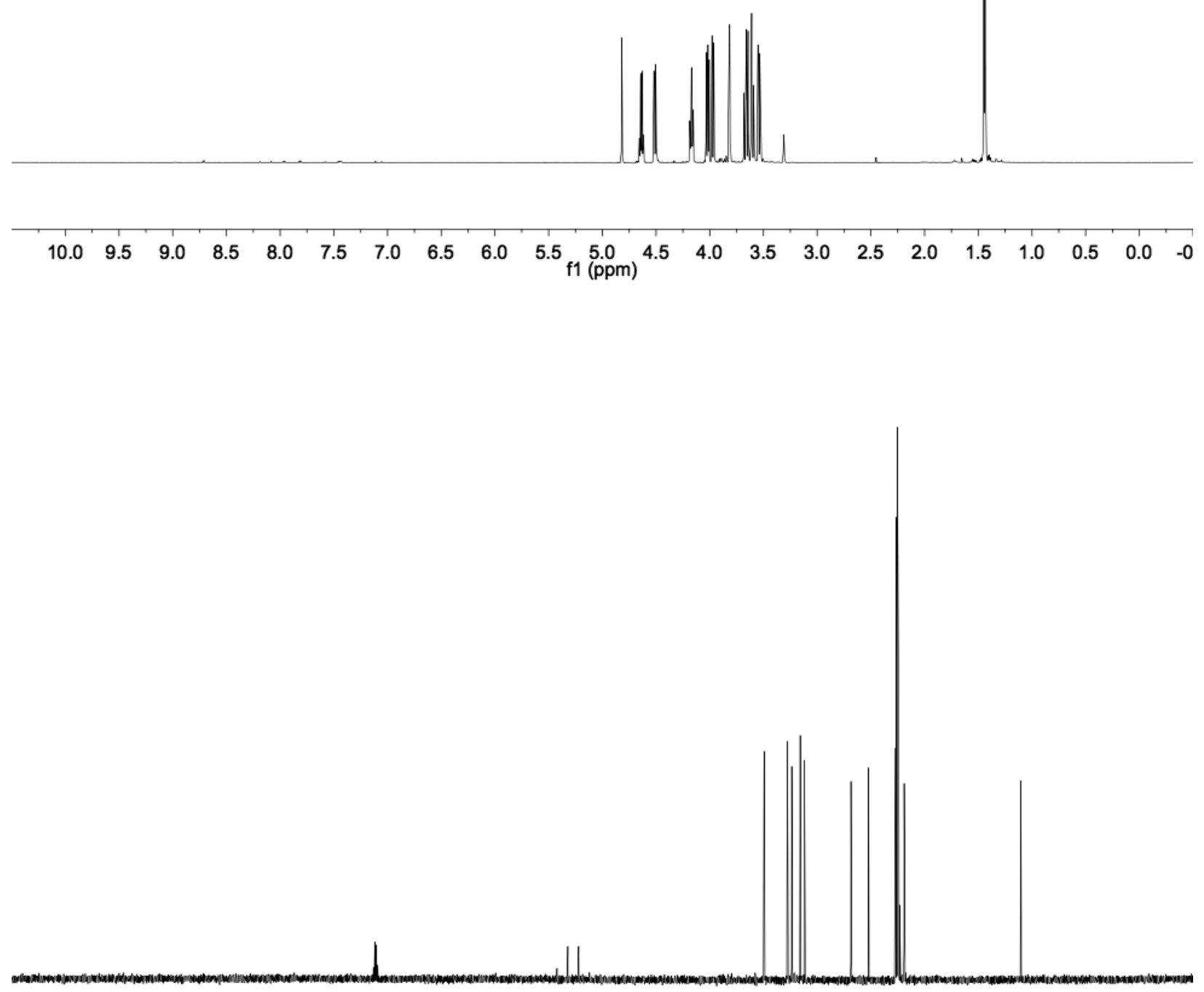

$\begin{array}{lllllllllllllllllllllllll}230 & 220 & 210 & 200 & 190 & 180 & 170 & 160 & 150 & 140 & 130 & 120 & 110 & 100 & 90 & 80 & 70 & 60 & 50 & 40 & 30 & 20 & 10 & 0 & -10\end{array}$ 

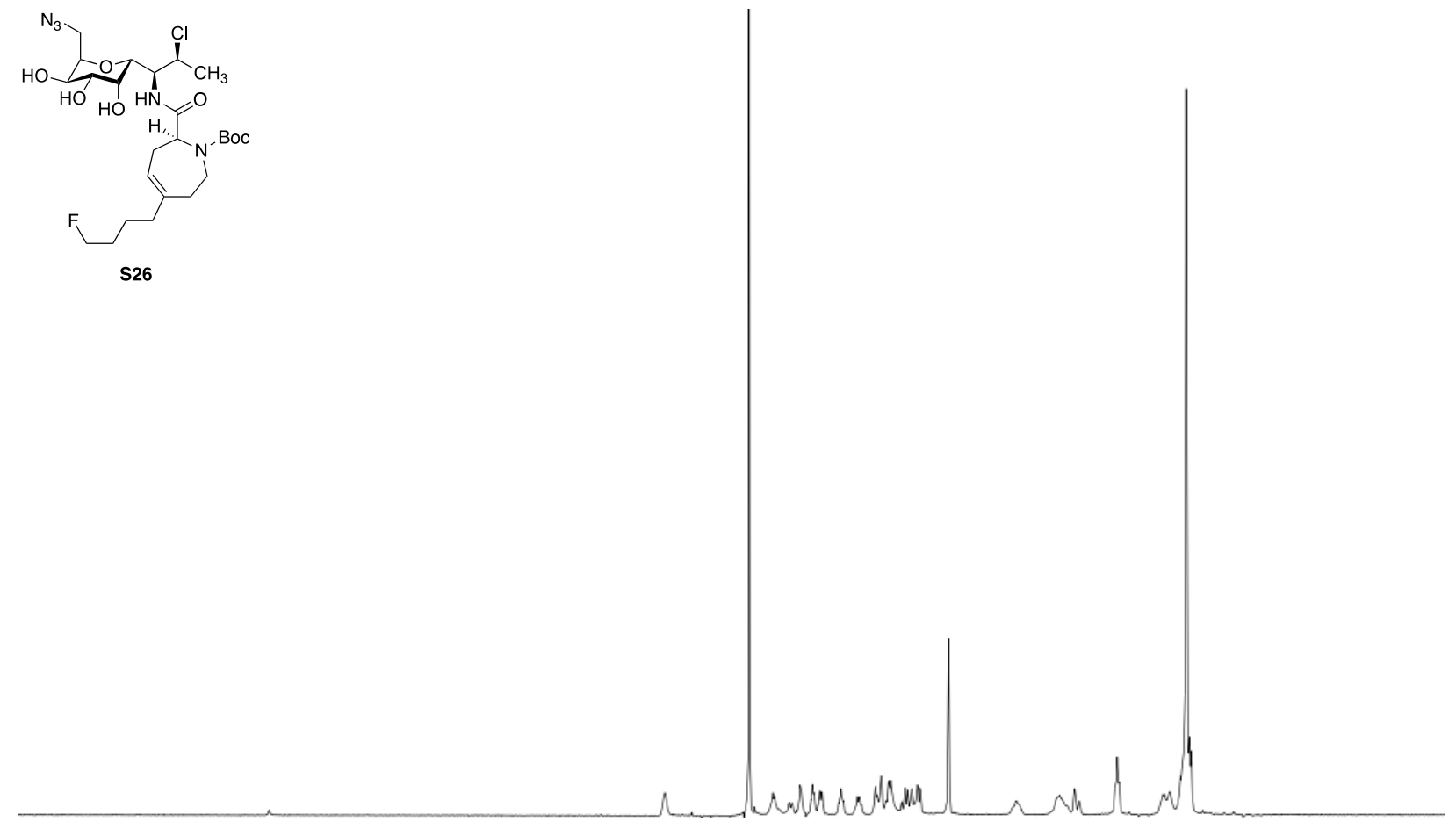

$\begin{array}{lllllllllllllllllllllll}1.5 & 10.0 & 9.5 & 9.0 & 8.5 & 8.0 & 7.5 & 7.0 & 6.5 & 6.0 & 5.5 & \underset{\mathrm{f} 1}{(\mathrm{ppm})} \mathbf{5 . 0} & 4.5 & 4.0 & 3.5 & 3.0 & 2.5 & 2.0 & 1.5 & 1.0 & 0.5 & 0.0 & -0\end{array}$

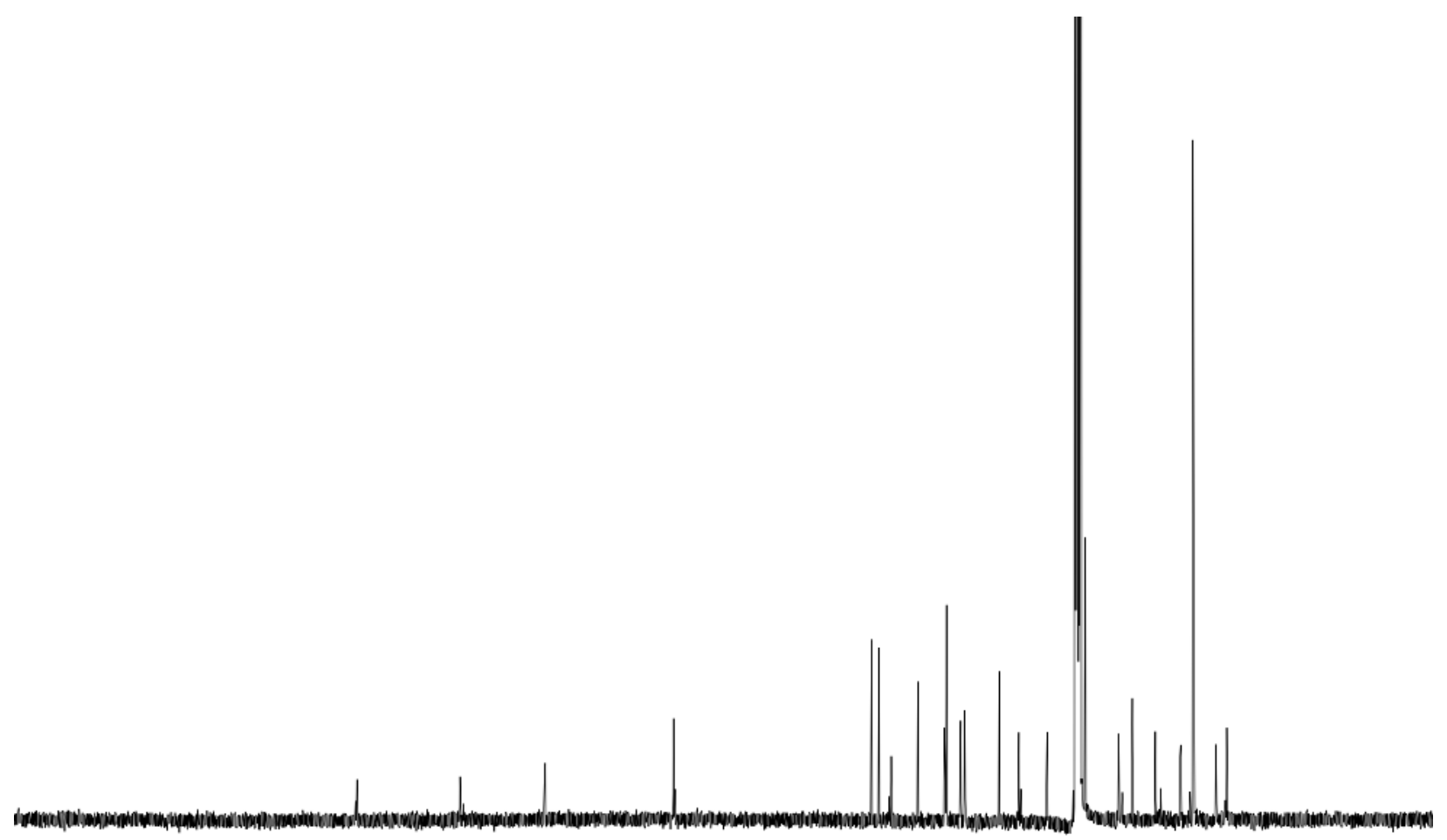

$\begin{array}{lllllllllllllllllllllllll}230 & 220 & 210 & 200 & 190 & 180 & 170 & 160 & 150 & 140 & 130 & 120 & 110 & 100 & 90 & 80 & 70 & 60 & 50 & 40 & 30 & 20 & 10 & 0 & -10\end{array}$ 

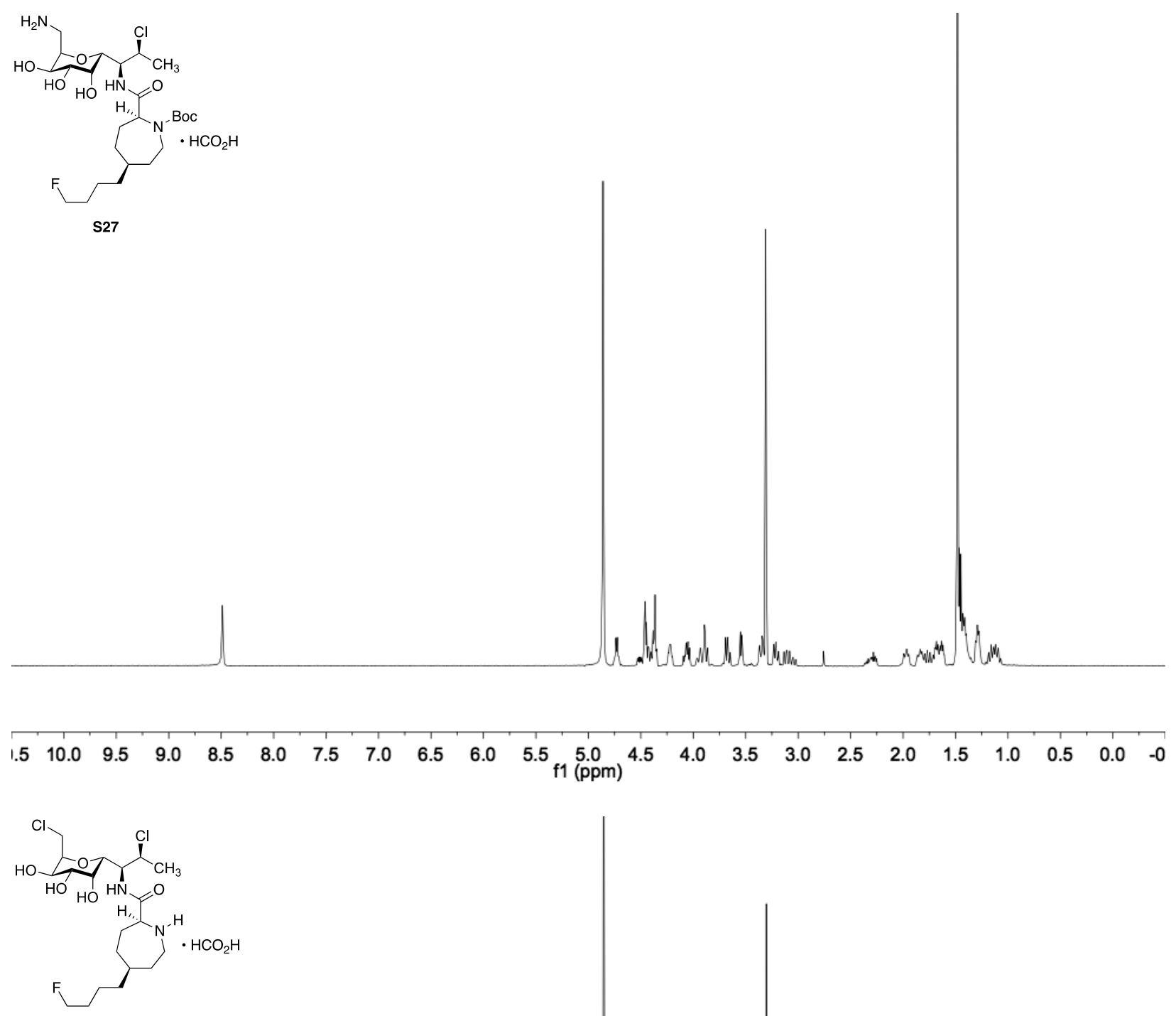

43

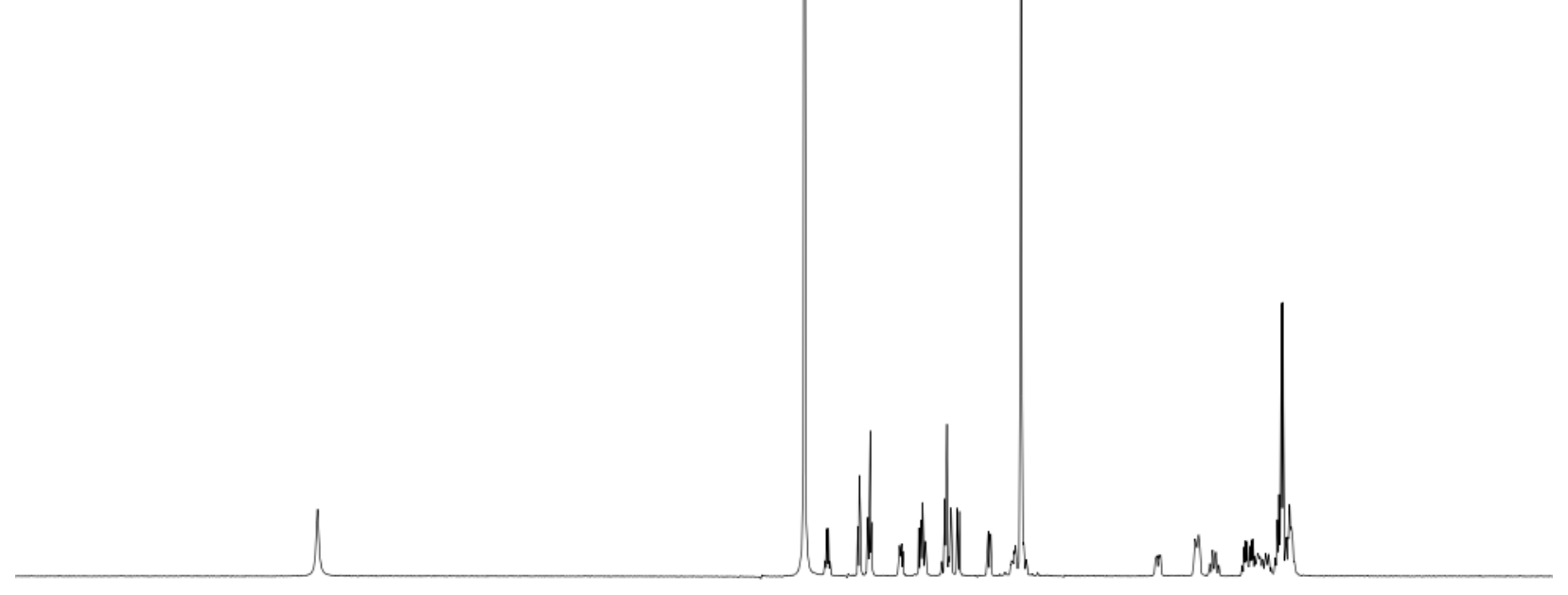

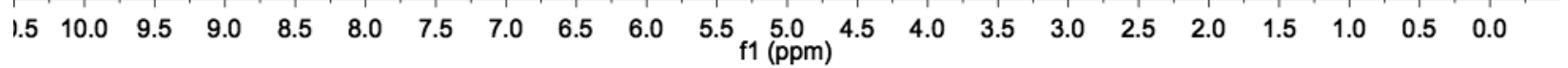



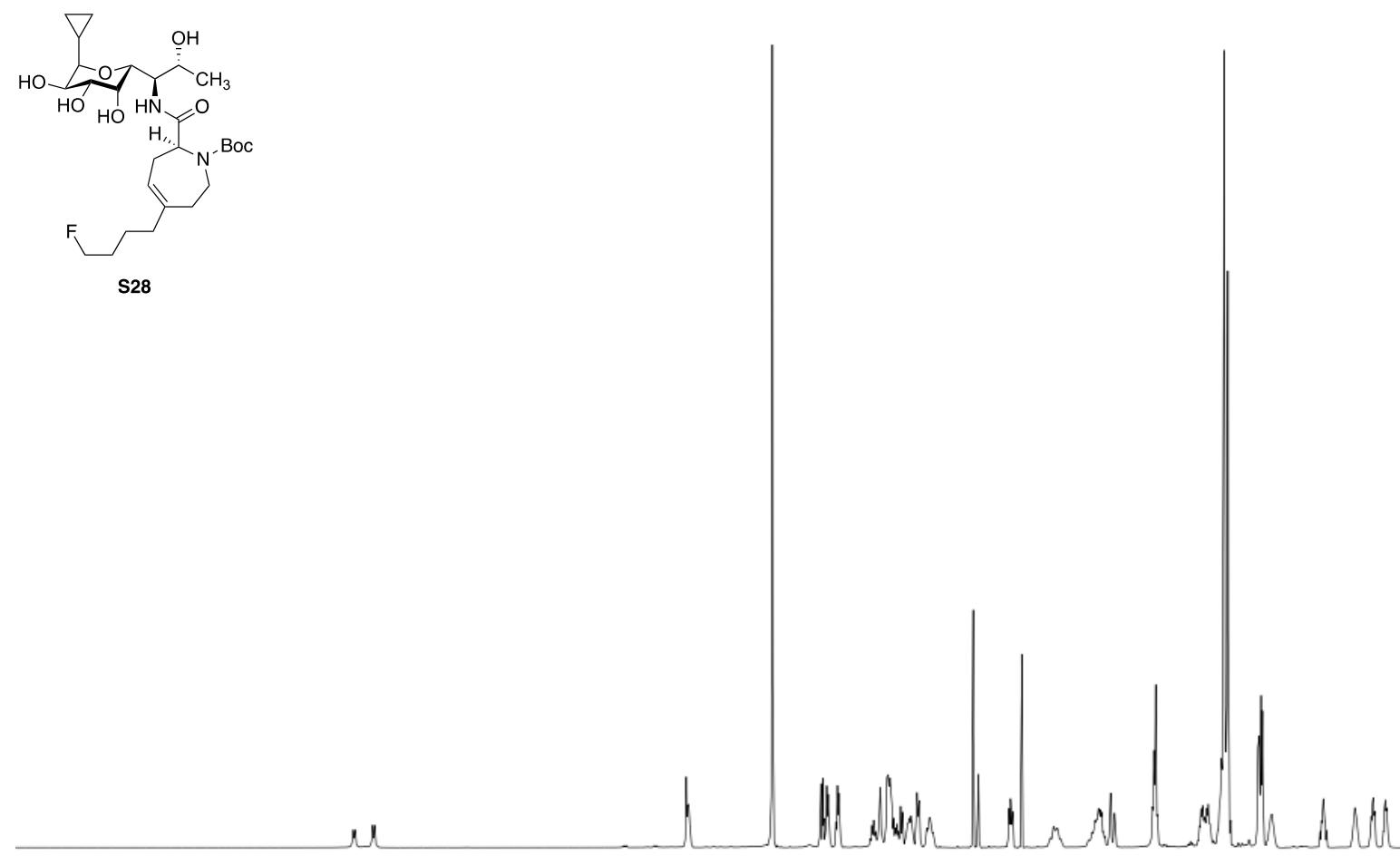

\begin{tabular}{llllllllllllllllllllll}
\hline .5 & 10.0 & 9.5 & 9.0 & 8.5 & 8.0 & 7.5 & 7.0 & 6.5 & 6.0 & $5.5 \underset{\mathrm{f} 1}{\mathrm{f}(\mathrm{ppm})} \mathbf{5 . 0}$ & 4.5 & 4.0 & 3.5 & 3.0 & 2.5 & 2.0 & 1.5 & 1.0 & 0.5 & 0.0 & -0
\end{tabular}

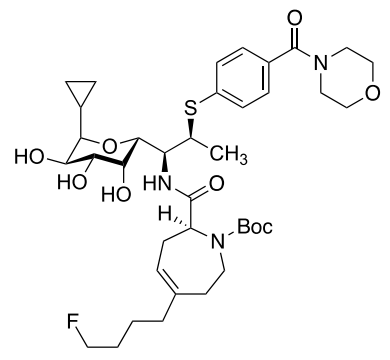

S30

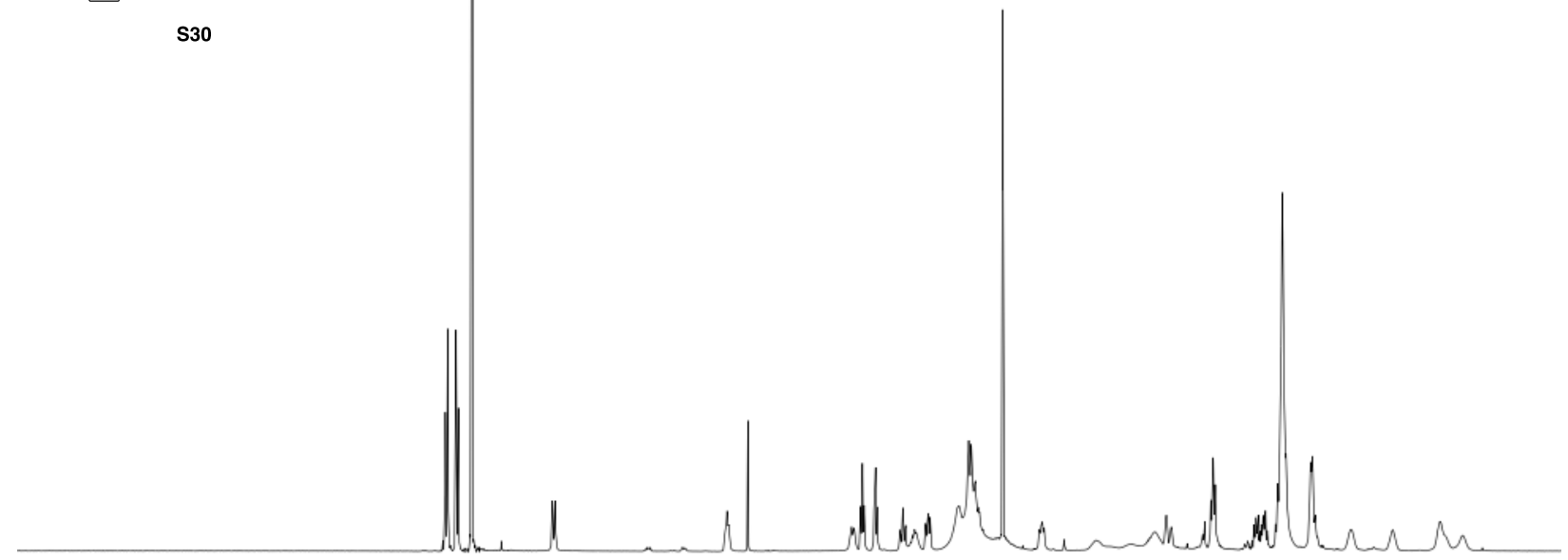

$\begin{array}{lllllllllllllllllllllll}1.5 & 10.0 & 9.5 & 9.0 & 8.5 & 8.0 & 7.5 & 7.0 & 6.5 & 6.0 & 5.5 & \underset{\mathrm{f} 1}{(\mathrm{ppm})} \mathbf{5 . 0} & 4.5 & 4.0 & 3.5 & 3.0 & 2.5 & 2.0 & 1.5 & 1.0 & 0.5 & 0.0 & -0\end{array}$ 

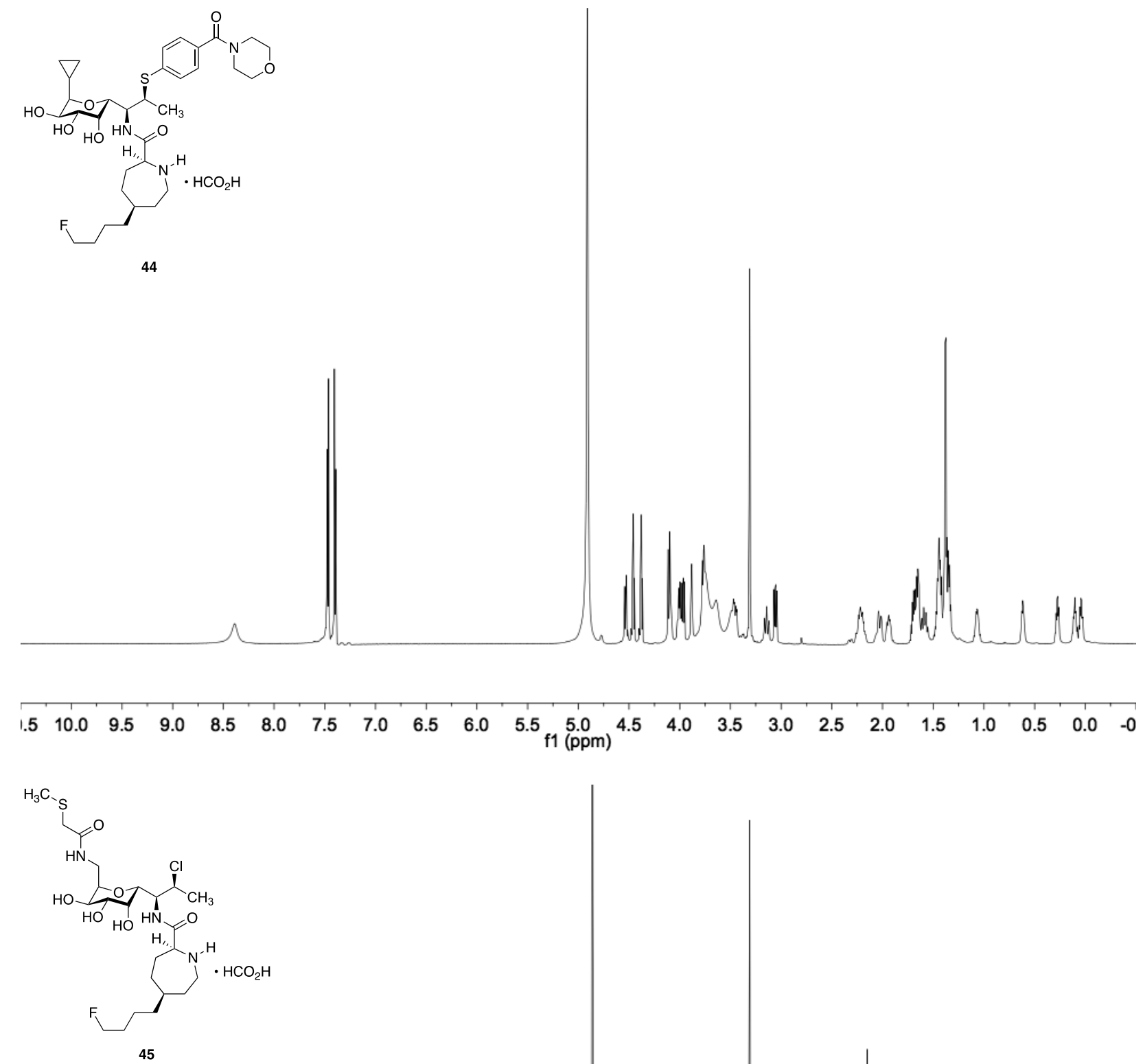

45

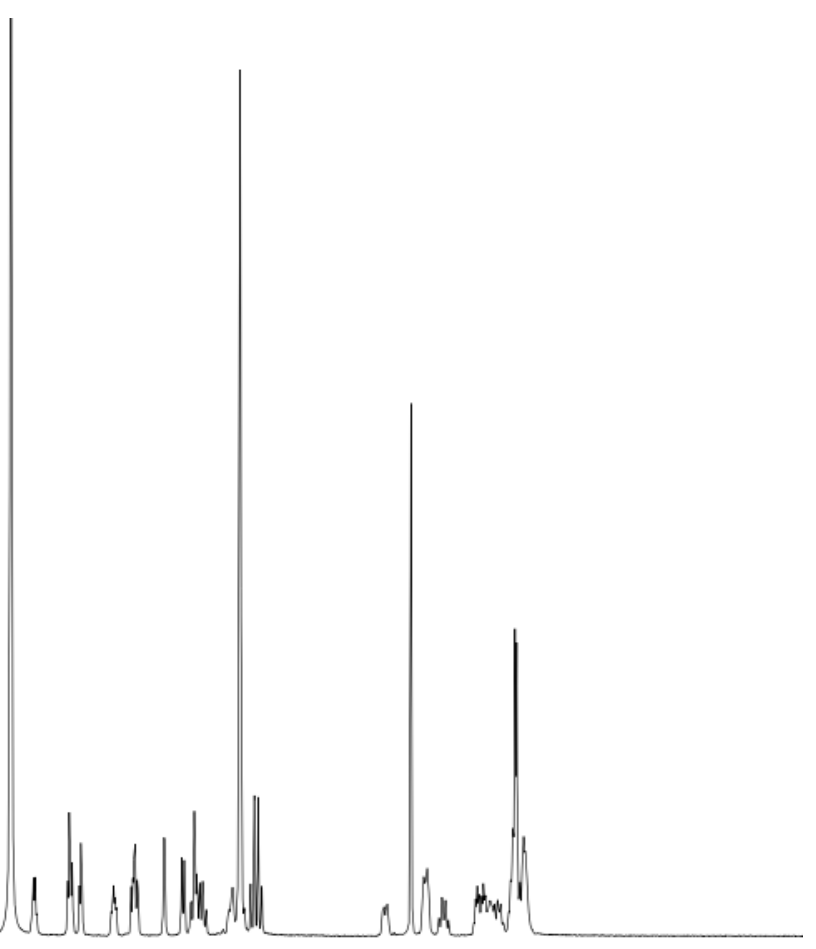

$\begin{array}{lllllllllllllllllllllll}1.5 & 10.0 & 9.5 & 9.0 & 8.5 & 8.0 & 7.5 & 7.0 & 6.5 & 6.0 & 5.5 \underset{\mathrm{f} 1}{(\mathrm{ppm})} \mathbf{5 . 0} & 4.5 & 4.0 & 3.5 & 3.0 & 2.5 & 2.0 & 1.5 & 1.0 & 0.5 & 0.0 & -0\end{array}$ 

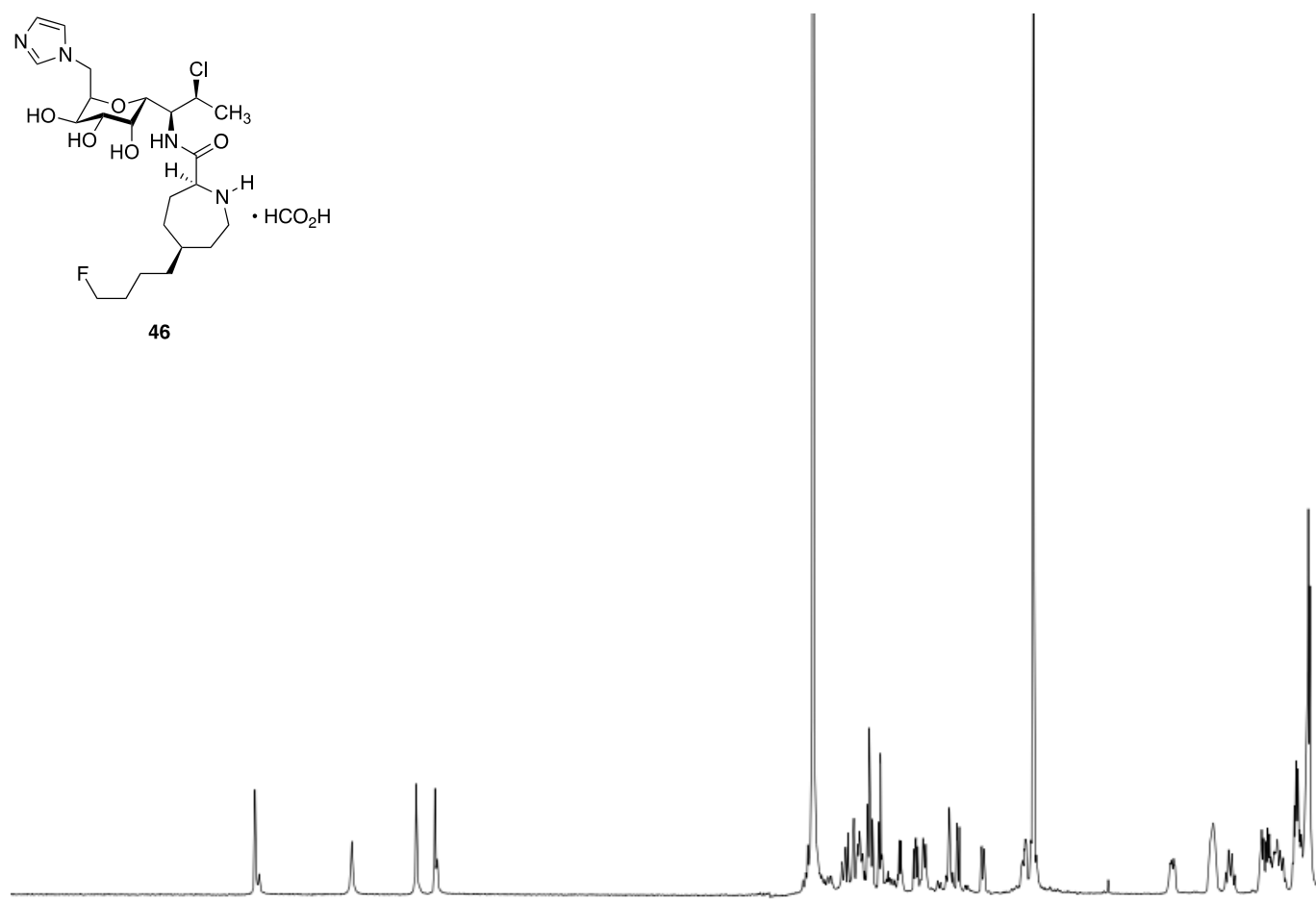

\begin{tabular}{lllllllllllllllllllllll}
\hline .5 & 10.0 & 9.5 & 9.0 & 8.5 & 8.0 & 7.5 & 7.0 & 6.5 & 6.0 & $5.5 \underset{\mathrm{f} 1}{\mathrm{f}} \mathbf{( \mathrm { ppm } )}$ & 4.5 & 4.0 & 3.5 & 3.0 & 2.5 & 2.0 & 1.5 & 1.0 & 0.5 & 0.0 & -0
\end{tabular} 

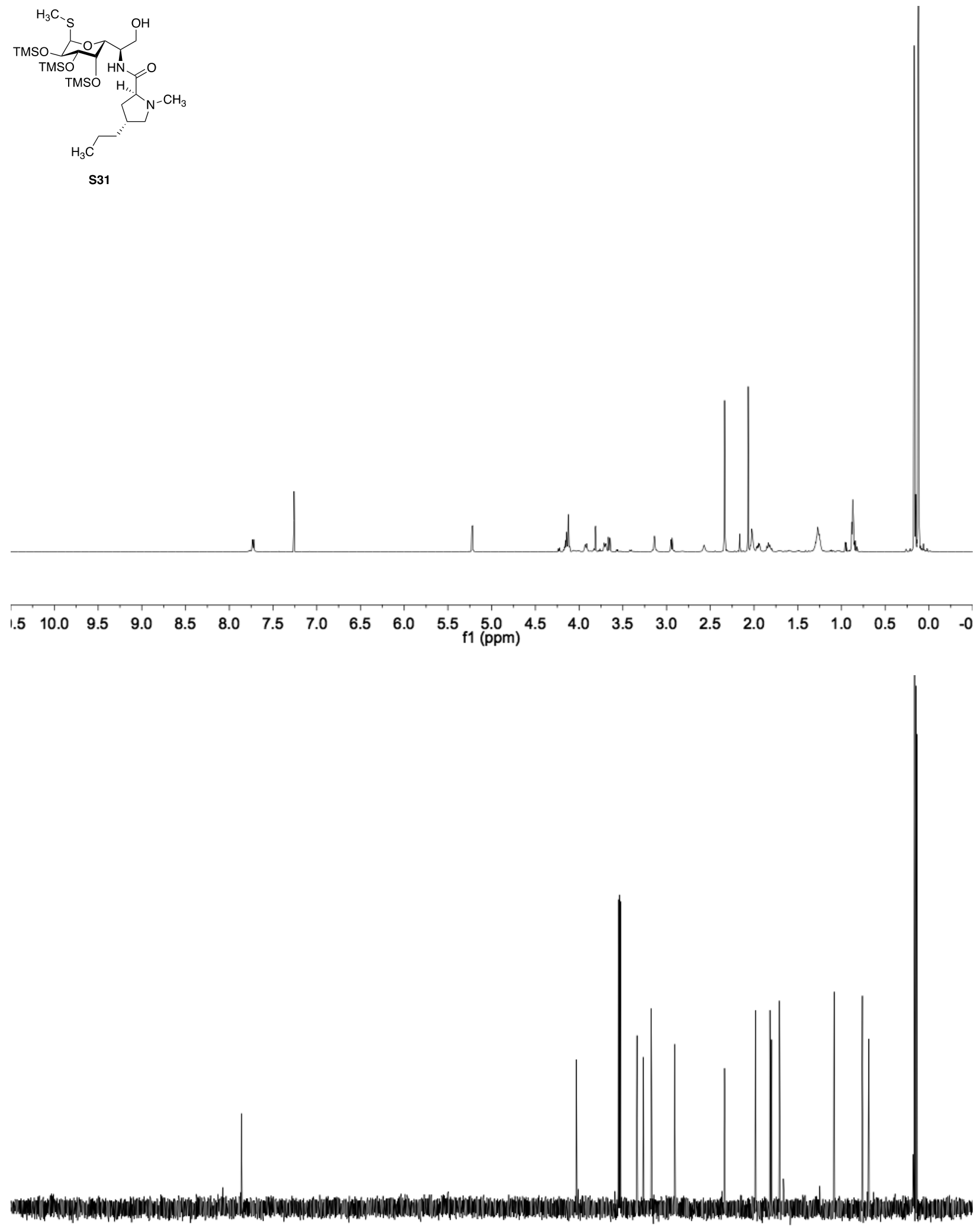

$\begin{array}{lllllllllllllllllllllllllll}230 & 220 & 210 & 200 & 190 & 180 & 170 & 160 & 150 & 140 & 130 & 120 & 110 & 100 & 90 & 80 & 70 & 60 & 50 & 40 & 30 & 20 & 10 & 0 & -10\end{array}$ 

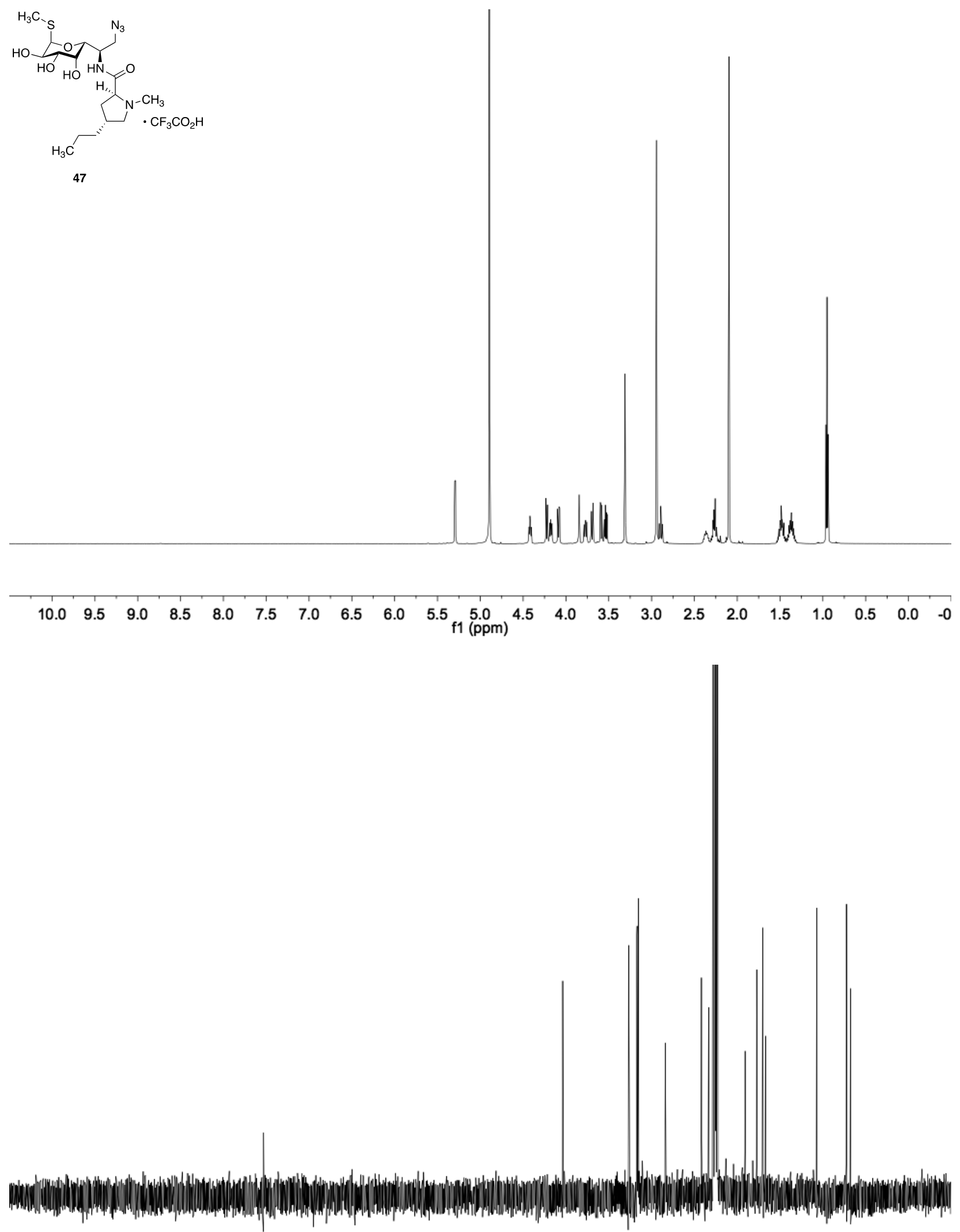

$\begin{array}{llllllllllllllllllllllllll}230 & 220 & 210 & 200 & 190 & 180 & 170 & 160 & 150 & 140 & 130 & 120 & 110 & 100 & 90 & 80 & 70 & 60 & 50 & 40 & 30 & 20 & 10 & 0 & -10\end{array}$ 


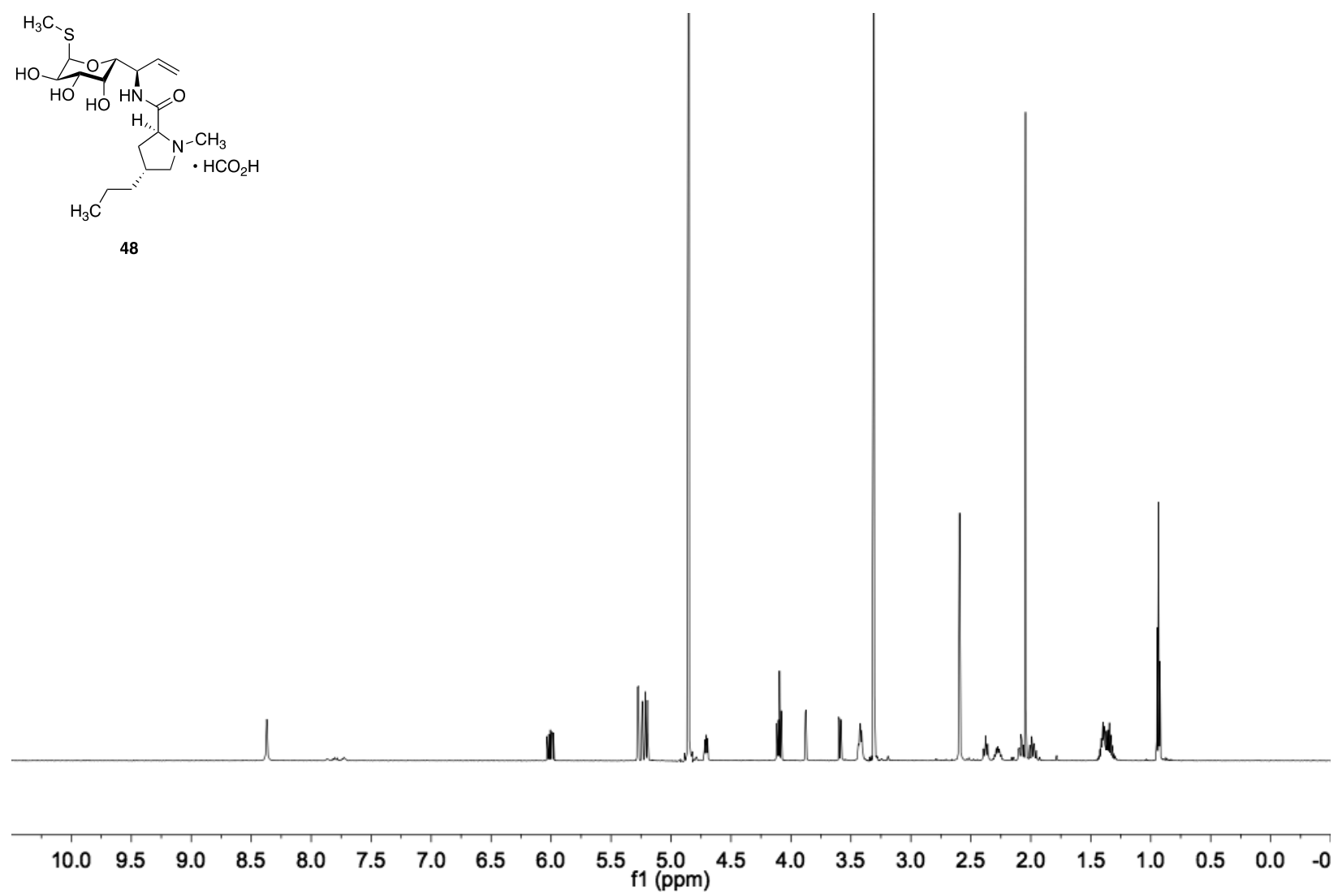



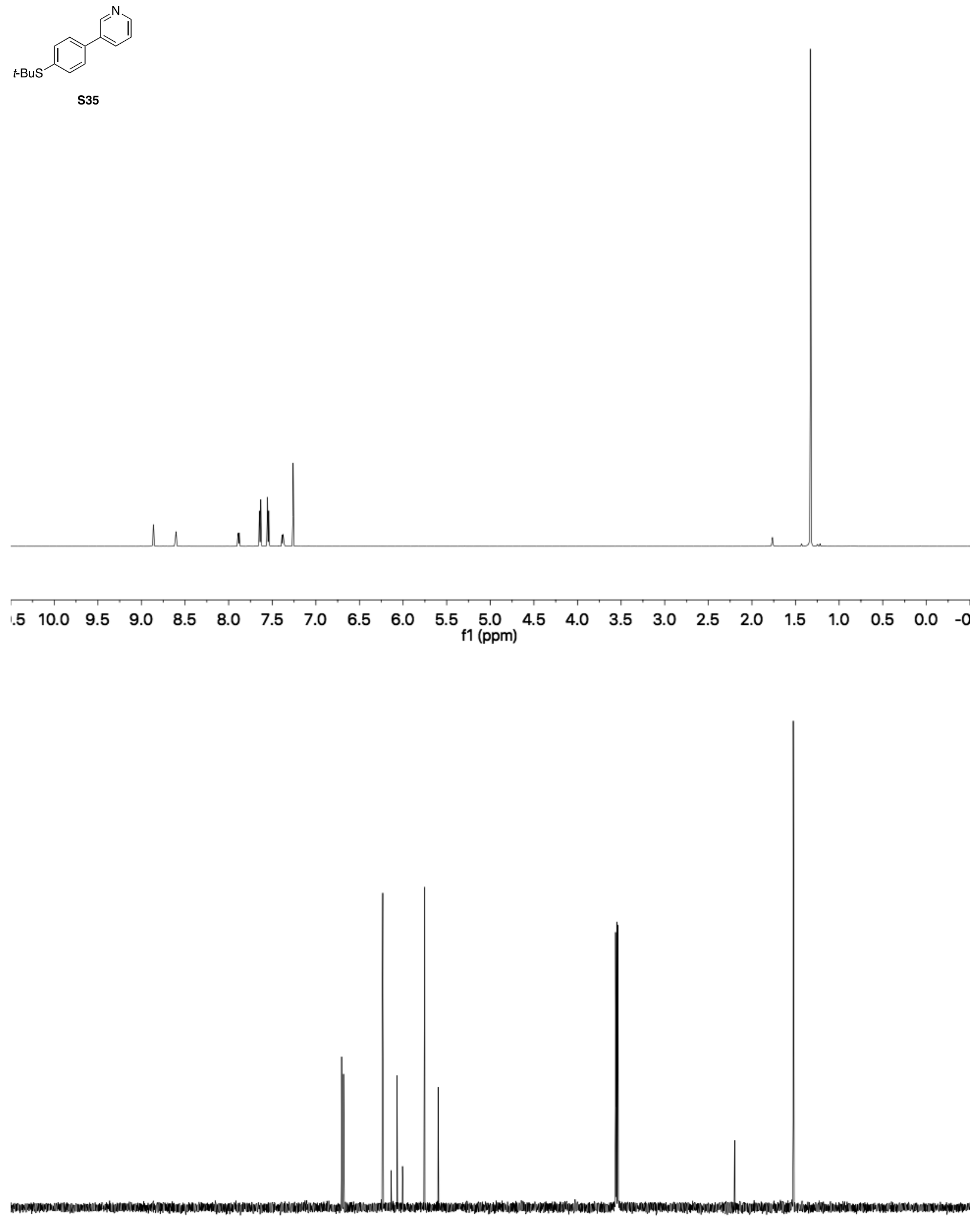

$\begin{array}{lllllllllllllllllllllllll}230 & 220 & 210 & 200 & 190 & 180 & 170 & 160 & 150 & 140 & 130 & 120 & 110 & 100 & 90 & 80 & 70 & 60 & 50 & 40 & 30 & 20 & 10 & 0 & -10\end{array}$ 

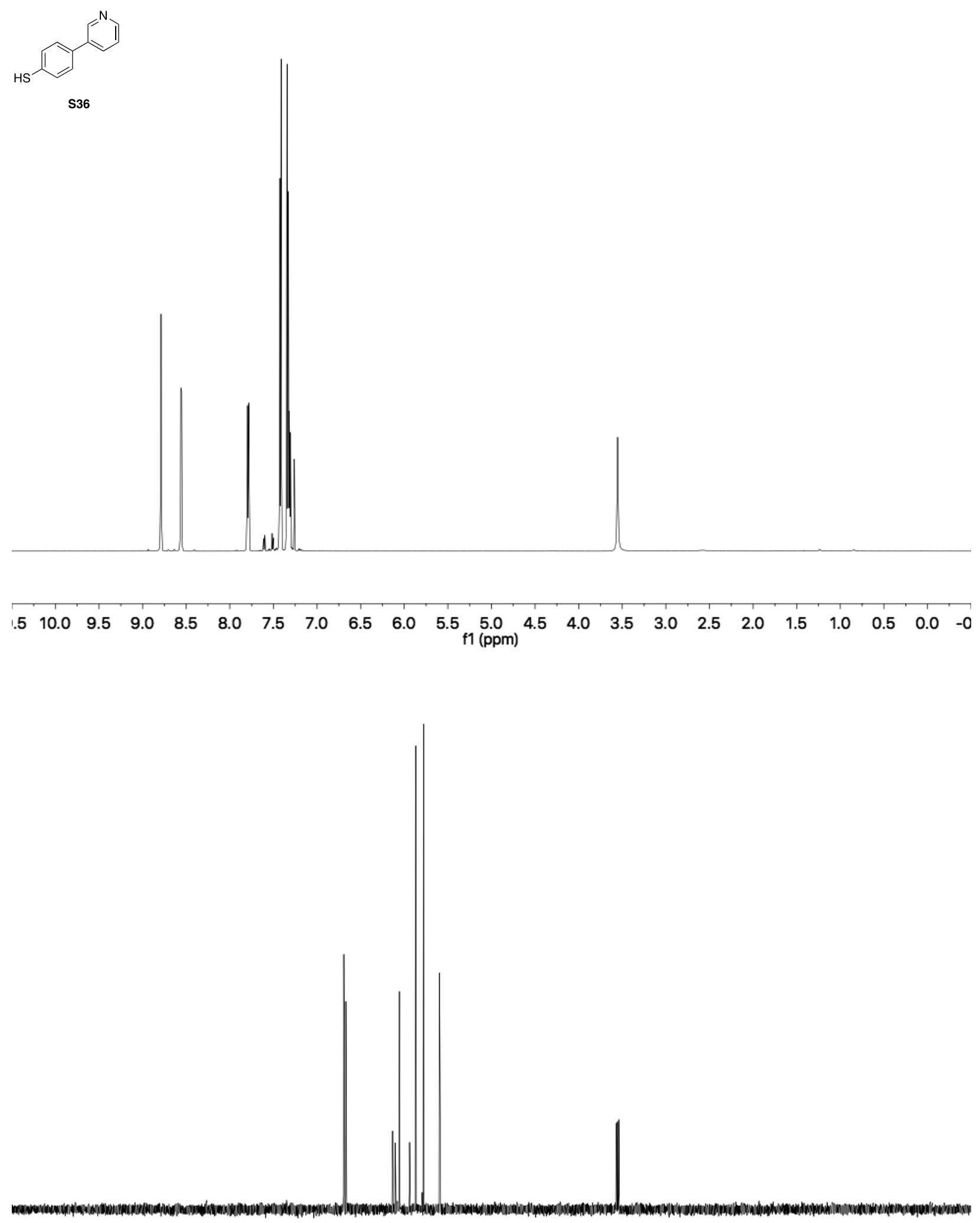

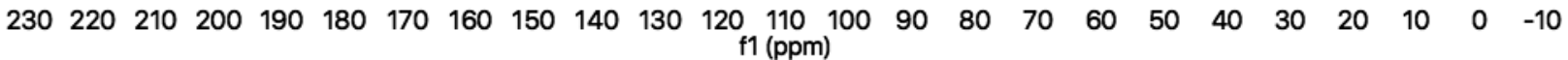




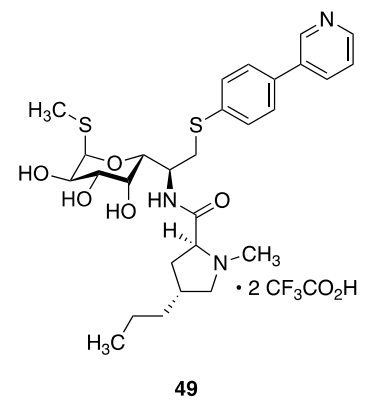

49
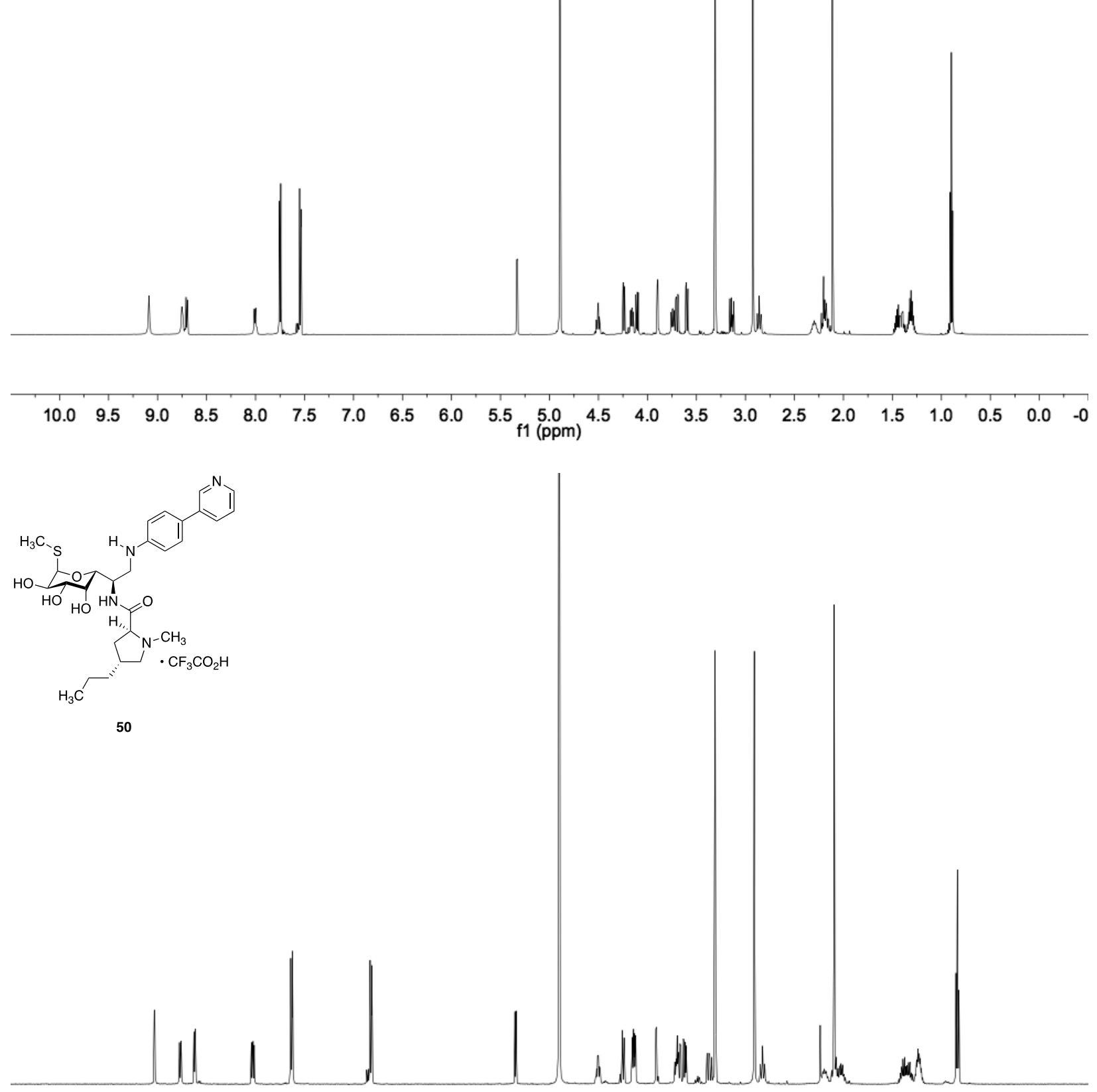

\begin{tabular}{llllllllllll}
\hline .5 & 10.0 & 9.5 & 9.0 & 8.5 & 8.0 & 7.5 & 7.0 & 6.5 & 6.0 & 5.5 & $\begin{array}{l}5.0 \\
\mathrm{fpm})\end{array}$ \\
4.5 & 4.0 & 3.5 & 3.0 & 2.5 & 2.0 & 1.5 & 1.0 & 0.5 & 0.0 & -0
\end{tabular} 